In cooperation with the Houston-Galveston Area Council and the Texas Commission on Environmental Quality

\title{
Water-Quality, Sediment-Quality, Stream- Habitat, and Biological Data for Mustang Bayou Near Houston, Texas, 2004-05
}

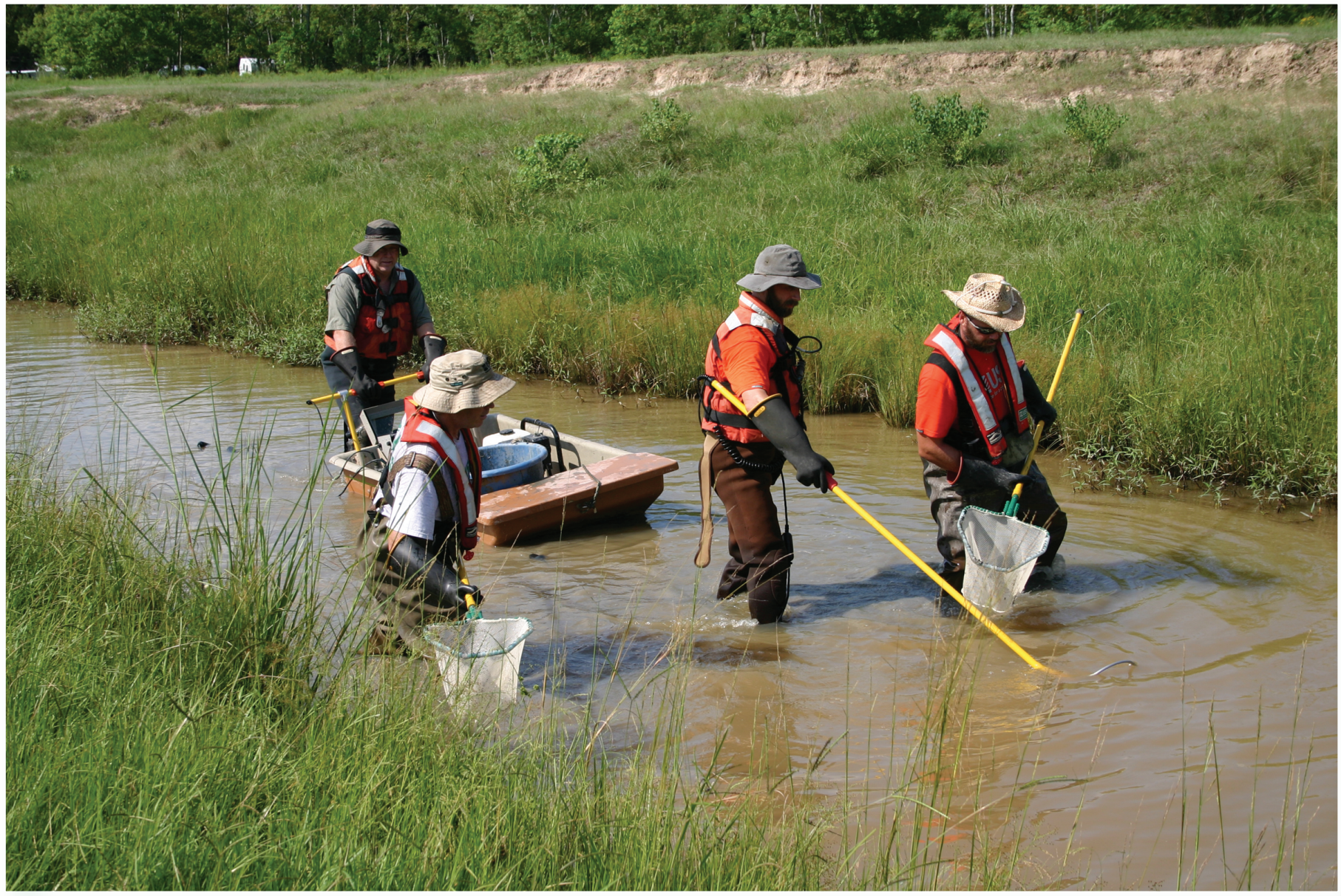

Data Series 263 
Cover: U.S. Geological Survey personnel fish shocking at Mustang Bayou at East South Street, Alvin, Texas, September 27, 2005. 


\section{Water-Quality, Sediment-Quality, Stream- Habitat, and Biological Data for Mustang Bayou Near Houston, Texas, 2004-05}

By Debra A. Sneck-Fahrer and Jeffery W. East

Prepared in cooperation with the Houston-Galveston Area Council and the Texas Commission on Environmental Quality under the authorization of the Texas Clean Rivers Act and applicable Federal law

Data Series 263 


\section{U.S. Department of the Interior DIRK KEMPTHORNE, Secretary}

\section{U.S. Geological Survey \\ Mark D. Myers, Director}

\section{U.S. Geological Survey, Reston, Virginia: 2007}

For product and ordering information:

World Wide Web: http://www.usgs.gov/pubprod

Telephone: 1-888-ASK-USGS

For more information on the USGS--the Federal source for science about the Earth, its natural and living resources, natural hazards, and the environment:

World Wide Web: http://www.usgs.gov

Telephone: 1-888-ASK-USGS

Any use of trade, product, or firm names is for descriptive purposes only and does not imply endorsement by the U.S. Government.

Although this report is in the public domain, permission must be secured from the individual copyright owners to reproduce any copyrighted materials contained within this report.

Suggested citation:

Sneck-Fahrer, D.A., and East, J.W., 2007, Water-quality, sediment-quality, stream-habitat, and biological data for Mustang Bayou near Houston, Texas, 2004-05: U.S. Geological Survey Data Series 263, 81 p. 


\section{Contents}

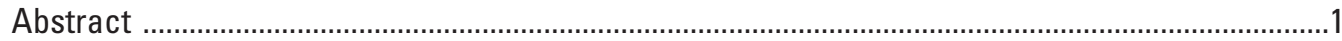

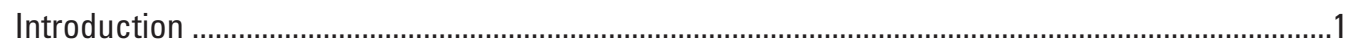

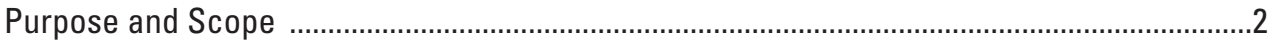

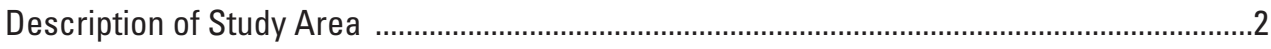

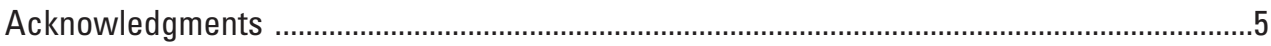

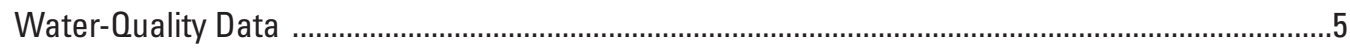

Continuously Monitored Water-Quality Properties ......................................................................

Periodically Collected Water-Quality Properties and Constituents ........................................6

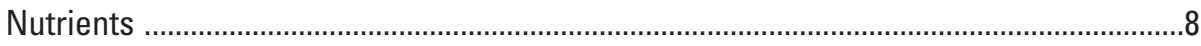

Biochemical Oxygen Demand, Chlorophyll-a, and E. Coli ..........................................

Chloride, Sulfate, Suspended Solids, and Dissolved Solids ..........................................12

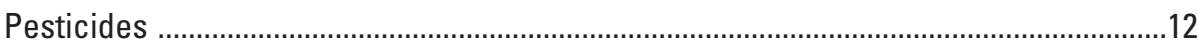

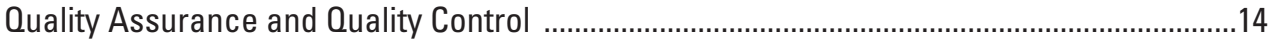

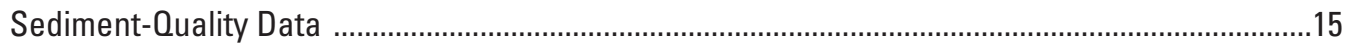

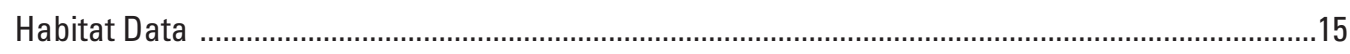

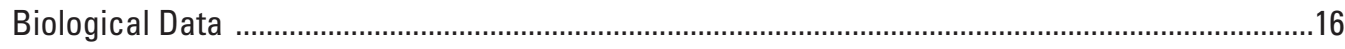

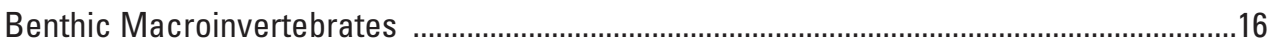

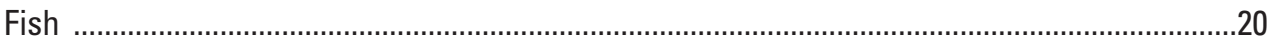

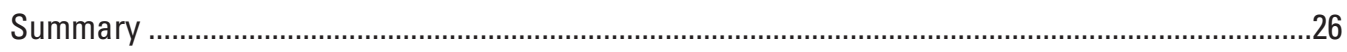

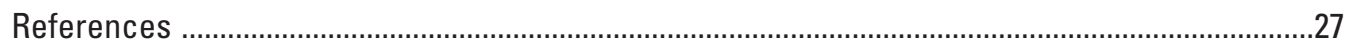

Appendixes

1. Periodically Collected Water-Quality Properties and Constituents ..................................31

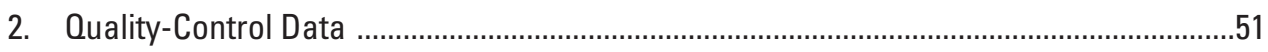

3. Water-Quality Properties and Sediment-Quality Constituents ......................................57

4. Stream-Habitat Data and Computed Metrics …….......................................................61

5. Benthic Macroinvertebrate Taxa and Counts of Individual Taxa ...................................65

6. Benthic Macroinvertebrate Data and Computed Metrics ...............................................71

7. Fish Taxa and Counts of Individual Taxa .....................................................................75

8. Fish-Community Data and Computed Metrics .................................................................79

\section{Figures}

1-2. Maps showing:

1. Mustang Bayou watershed (study area) near Houston, Texas .................................

2. Land-cover distribution in Mustang Bayou watershed near Houston, Texas, 2002

3-7. Graphs showing:

3. Rainfall at National Weather Service site 80204 (Alvin), September 2004August 2005

4. Diurnal dissolved oxygen concentrations at sites (A) M4, Mustang Bayou at County Road 99 near Alvin, and (B) M5, Mustang Bayou at County Road 48 near Fresno, August 2005 
5. Distribution of $(A)$ ammonia nitrogen, $(B)$ ammonia plus organic nitrogen, (C) nitrite nitrogen, (D) nitrite plus nitrate nitrogen, (E) orthophosphate phosphorus, and (F) total phosphorus concentrations in water samples periodically collected from six sites in Mustang Bayou near Houston, Texas, September 2004-August 2005

6. Distribution of $(A)$ biochemical oxygen demand concentrations,

(B) chlorophyll-a concentrations, and (C) E. coli densities in water samples periodically collected from six sites in Mustang Bayou near Houston, Texas, September 2004-August 2005

7. Distribution of (A) chloride, (B) sulfate, (C) suspended solids, and (D) dissolved solids concentrations in water samples periodically collected from six sites in Mustang Bayou near Houston, Texas, September 2004August 2005

8. Boxplots showing distribution of selected pesticide concentrations in water samples collected from six sites, combined, in Mustang Bayou near Houston, Texas, September 2004-August 2005

9-13. Graphs showing:

9. Number of specimens of $(A)$ benthic (non-insect) invertebrate taxa, and (B) insect taxa collected from representative reach at each of six sites in Mustang Bayou near Houston, Texas, September 2004-August 2005

10. Relative abundance of benthic macroinvertebrate trophic groups from representative reach at each of six sites in Mustang Bayou near Houston, Texas, September 2004-August 2005

11. Relative abundance of major fish families from representative reach at each of six sites in Mustang Bayou near Houston, Texas, September 2004August 2005

12. Relative abundance of fish functional feeding groups from representative reach at each of six sites in Mustang Bayou near Houston, Texas, September 2004-August 2005

13 Number of fish collected relative to number of fish species from representative reach at each of six sites in Mustang Bayou near Houston, Texas, September 2004-August 2005

\section{Tables}

1. Data-collection sites in Mustang Bayou near Houston, Texas, September 2004August 2005

2. Summary of 24-hour water temperature data collected at sites in Mustang Bayou near Houston, Texas, September 2004-August 2005

3. Summary of 24-hour pH data collected at sites in Mustang Bayou near Houston, Texas, September 2004-August 2005

4. Summary of 24-hour specific conductance data collected at sites in Mustang Bayou near Houston, Texas, September 2004-August 2005 . .8

5. Summary of 24-hour dissolved oxygen data collected at sites in Mustang Bayou near Houston, Texas, September 2004-August 2005

6. Screening levels to identify secondary concerns for selected water-quality constituents and primary standard for contact and noncontact recreation for E. coli 
7. Summary of pesticide detections at sites in Mustang Bayou near Houston, Texas, September 2004-August 2005

8. Habitat quality index aquatic-life-use scoring for representative reach at each of six sites in Mustang Bayou near Houston, Texas, September 2004-August 2005

9. Metrics and aquatic-life-use scoring for benthic macroinvertebrates in representative reach at each of six sites in Mustang Bayou near Houston, Texas, September 2004-August 2005

10. Fish species collected from representative reach at each of six sites in Mustang Bayou near Houston, Texas, September 2004-August 2005

11. Index of biotic integrity aquatic-life-use scoring for ecoregion 34 for fish in representative reach at each of six sites in Mustang Bayou near Houston, Texas, September 2004-August 2005

12. Average aquatic-life-use scores for stream habitat, benthic macroinvertebrates, and fish in representative reach at each of six sites in Mustang Bayou near Houston, Texas, September 2004-August 2005

\section{Conversion Factors and Datums}

\section{Inch/Pound to SI}

\begin{tabular}{|c|c|c|}
\hline Multiply & By & To obtain \\
\hline \multicolumn{3}{|c|}{ Length } \\
\hline inch (in.) & 25.4 & millimeter $(\mathrm{mm})$ \\
\hline mile (mi) & 1.609 & kilometer $(\mathrm{km})$ \\
\hline \multicolumn{3}{|c|}{ Area } \\
\hline square mile $\left(\mathrm{mi}^{2}\right)$ & 2.590 & square kilometer $\left(\mathrm{km}^{2}\right)$ \\
\hline
\end{tabular}

Temperature in degrees Fahrenheit $\left({ }^{\circ} \mathrm{F}\right)$ may be converted to degrees Celsius $\left({ }^{\circ} \mathrm{C}\right)$ as follows:

${ }^{\circ} \mathrm{C}=\left({ }^{\circ} \mathrm{F}-32\right) / 1.8$

Temperature in degrees Celsius $\left({ }^{\circ} \mathrm{C}\right)$ may be converted to degrees Fahrenheit $\left({ }^{\circ} \mathrm{F}\right)$ as follows:

${ }^{\circ} \mathrm{F}=\left(1.8 x^{\circ} \mathrm{C}\right)+32$

Specific conductance is given in microsiemens per centimeter at 25 degrees Celsius $(\mu \mathrm{S} / \mathrm{cm})$.

Concentrations of chemical constituents in water are given in either milligrams per liter (mg/L) or micrograms per liter $(\mu \mathrm{g} / \mathrm{L})$.

E. coli densities in water are given in colonies per 100 milliliters (cols./100 mL).

\section{Datums}

Vertical coordinate information is referenced to National Geodetic Vertical Datum of 1929 (NGVD 29).

Horizontal coordinate information is referenced to North American Datum of 1983 (NAD 83). 
Blank Page 


\title{
Water-Quality, Sediment-Quality, Stream- Habitat, and Biological Data for Mustang Bayou Near Houston, Texas, 2004-05
}

\author{
By Debra A. Sneck-Fahrer and Jeffery W. East
}

\section{Abstract}

The U.S. Geological Survey, in cooperation with the Houston-Galveston Area Council and the Texas Commission on Environmental Quality, collected water-quality, streamhabitat, and biological data from six sites (downstream order M6-M1) primarily in Brazoria County southeast of Houston, Texas, during September 2004-August 2005 and collected bed sediment data from one site in September 2005. Water-quality data collection consisted of continuously monitored (for periods of 24 hours to several days, six times) water temperature, $\mathrm{pH}$, specific conductance, and dissolved oxygen and periodically collected samples of several properties and constituents. Monitored dissolved oxygen measurements were below minimum and 24-hour criteria at all sites except M2. Nitrogen compounds, phosphorus, biochemical oxygen demand, chlorophyll- $a$, E. coli, chloride, sulfate, solids, suspended sediment concentration, and pesticides were assessed at all sites. Concentrations of nitrogen compounds and phosphorus did not exceed Texas State screening levels. Biochemical oxygen demand was less than 4.0 milligrams per liter at all sites except M6, where the maximum concentration was 8.1 milligrams per liter. Concentrations of chlorophyll- $a$ were less than the State screening level at all sites except M6, where four of eight samples equaled or exceeded the screening level. Twenty of 48 samples from Mustang Bayou had E. coli densities that exceeded the State single-sample water-quality standard. Median chloride concentrations from each site were between 42.2 and 123 milligrams per liter. Fifteen pesticide compounds (six herbicides and nine insecticides) were detected in 24 water samples. The most frequently detected pesticide was atrazine, which was found in every sample. Other frequently detected pesticides were 2-chloro-4-isopropylamino-6-aminos-triazine (CIAT), prometon, tebuthiuron, fipronil, and the pesticide degradates, fipronil sulfide and fipronil sulfone. Sediment samples were collected from the stream bottom at M1 and analyzed for concentrations of trace elements (metals), polycyclic aromatic hydrocarbons, organochlorine pesticides, and polychlorinated biphenyls. No organochlorine pesticides or polychlorinated biphenyls were detected. No concentrations of metals exceeded State screening levels. Measurable concentrations of 11 polycyclic aromatic hydrocarbon (PAH) compounds were detected, and three other PAH compounds were detected but not quantified by the laboratory. Stream habitat and aquatic biota (benthic macroinvertebrates and fish) were surveyed at each site three times during the study to evaluate aquatic life use. Characteristics of habitat measured during each survey were scored using a habitat quality index. Average aquatic-life-use scores were "limited" for M3-M6 and "intermediate" for M1 and M2. A total of 2,557 macroinvertebrate individuals were identified from Mustang Bayou. Benthic macroinvertebrate assemblages were scored using indexes specified by the Texas Commission on Environmental Quality. Average aquatic-life-use scores were "limited" at M1, "intermediate" at M3-M6, and "high" at M2. Forty-six species of fish representing 20 families were collected from Mustang Bayou. A total of 4,115 fish were collected. Sunfish (Centrarchidae) was the most abundant family, accounting for about 28 percent. Aquatic-life-use scores at sites in Mustang Bayou were determined using the regional index of biotic integrity for ecoregion 34 and were "high" for all sites.

\section{Introduction}

The Texas Commission on Environmental Quality (TCEQ) administers water-quality management programs with the goal of protecting, maintaining, and restoring water resources in Texas. One program is the Texas Clean Rivers Program (CRP), which was established by the 1991 Texas Legislature. Under the CRP, water-quality monitoring and assessments are conducted in 23 river and coastal basins statewide through contracts with partner agencies. The Houston-Galveston Area Council (H-GAC) is the partner agency for a 13-county service area in southeast Texas that includes the Houston metropolitan area. Biannually, CRP partners may do systematic monitoring studies whereby a variety of data are collected in water bodies that are not 
Water-Quality, Sediment-Quality, Stream-Habitat, and Biological Data for Mustang Bayou, Texas, 2004-05

monitored routinely. Data from these special studies help to determine whether additional assessment is needed to evaluate human-health concerns, the status of ecological conditions, or designated stream uses.

Mustang Bayou is southeast of Houston, Tex., primarily in Brazoria County, with the northwestern part of the watershed extending into Fort Bend County (fig. 1). With headwaters northwest of Fresno, Mustang Bayou extends approximately 30 miles to the southeast. Mustang Bayou has been extensively modified from its natural state, and many sections have been channelized. No segments of Mustang Bayou are currently (2007) listed on either the State 303(d) list for water-quality impairment or the 305(b) report for waterquality concerns (Texas Commission on Environmental Quality, 2005). However, urban development is occurring in the watershed, increasing the possibility of changes in the water quality, physical stream habitat, and aquatic biota.

Previous studies of Mustang Bayou include two Receiving Water Assessments (Luedke, 1997; Kelly, 2003) and a Use Attainability Assessment (Texas Natural Resource Conservation Commission, 1999a). However, because each study was local and addressed different aspects of water quality, physical stream habitat, and aquatic biota, these studies did not facilitate adoption of water-quality standards or classification of the aquatic life use of the bayou by the TCEQ. The current classification of Mustang Bayou is "high aquatic life use," which is that assumed for unclassified stream segments.

To better understand the combined effect of channelization and chemical or bacterial input on the ecological health of Mustang Bayou, the U.S. Geological Survey (USGS), in cooperation with H-GAC and TCEQ, conducted an assessment of current conditions at six sites on the stream. Waterquality, stream-habitat, and biological data were collected during September 2004-August 2005. Bed sediment data were collected at one site in September 2005. As a part of this study, these data were used to determine spatial variations in water quality and biological indicators to provide a more complete understanding of the relation between water quality, physical-habitat conditions, and biological metrics. In addition, data were assessed by applying State screening thresholds for selected water- and sediment-quality constituents and indexes for aquatic life use to water-quality results and computed habitat and biological metrics, respectively (Texas Commission on Environmental Quality, 2003a).

\section{Purpose and Scope}

The purpose of this report is to present water-quality, sediment-quality, stream-habitat, and biological data collected from selected sites on Mustang Bayou during September 2004-August 2005 and sediment-quality data in September 2005. Water-quality properties at six sites were measured continuously six times each during the study for monitoring periods of 24 hours to several days. Water-quality samples were collected at the six sites approximately bimonthly. Bed sediment data were collected at one site in September 2005. Stream-habitat and biological (benthic macroinvertebrate and fish) data were collected from a representative reach at each of the six sites in September 2004, April 2005, and August 2005.

Methods of assessment used during this study are described, and data are presented to compare waterquality changes at and among sites during the study period. This report evaluates biological data using standard indexes to assess the general health of the aquatic environment. Graphical techniques and computation of coefficients are used to compare data between stream reaches. Stream habitat and biological communities were scored on the basis of appropriate metrics using TCEQ protocol to evaluate aquatic-life-use ratings for each site (Texas Commission on Environmental Quality, 2003a).

\section{Description of Study Area}

The Mustang Bayou watershed, a drainage area of slightly more than 100 square miles, is in the Western Gulf Coastal Plain (ecoregion 34) (Griffith and others, 2004), which is characterized by Quaternary-age deltaic sands, silts, and clays. The Coastal Plain has a very low gradient so that streams generally are sluggish and have many meanders (Griffith and others, 2004). Land-cover types in the Mustang Bayou watershed (fig. 2) include grassland (about 51 percent), woody land (about 20 percent), and low-intensity developed (about 12 percent). Land use primarily is rural agriculture where channelized streams and irrigation canals are common. Natural vegetation comprises various grasses. Production of oil and gas is common in the lower part of the watershed. Urban development is occurring in the upper part of the watershed and near the largest city, Alvin, which had a population in 2000 of about 241,700 people (Texas State Data Center, 2005). There are 10 permitted wastewater dischargers in the watershed (fig. 1).

The climate along the Western Gulf Coastal Plain is influenced by the Gulf of Mexico and is classified as humid subtropical (Texas State Climatologist, 2004), which is characterized by cool and temperate winters, long and hot summers, high relative humidity, and prevailing winds from the south and southeast. A weather observation site near the center of the Mustang Bayou watershed (fig. 1; National Weather Service site 80204, Alvin) was used to characterize temperature and rainfall for this study. During the study, temperatures measured at the Alvin site ranged from a mean of about 55 degrees Fahrenheit $\left({ }^{\circ} \mathrm{F}\right)$ in the winter (December-February) to a mean of about $84^{\circ} \mathrm{F}$ in the summer (June-August), with maximum temperatures commonly higher than $90^{\circ} \mathrm{F}$ (National Climatic Data Center, 2004; 2005). During the study, total rainfall was 43.17 inches (National Climatic Data Center, 2004; 2005); 16.43 inches of this amount occurred in November 2004 (fig. 3). 


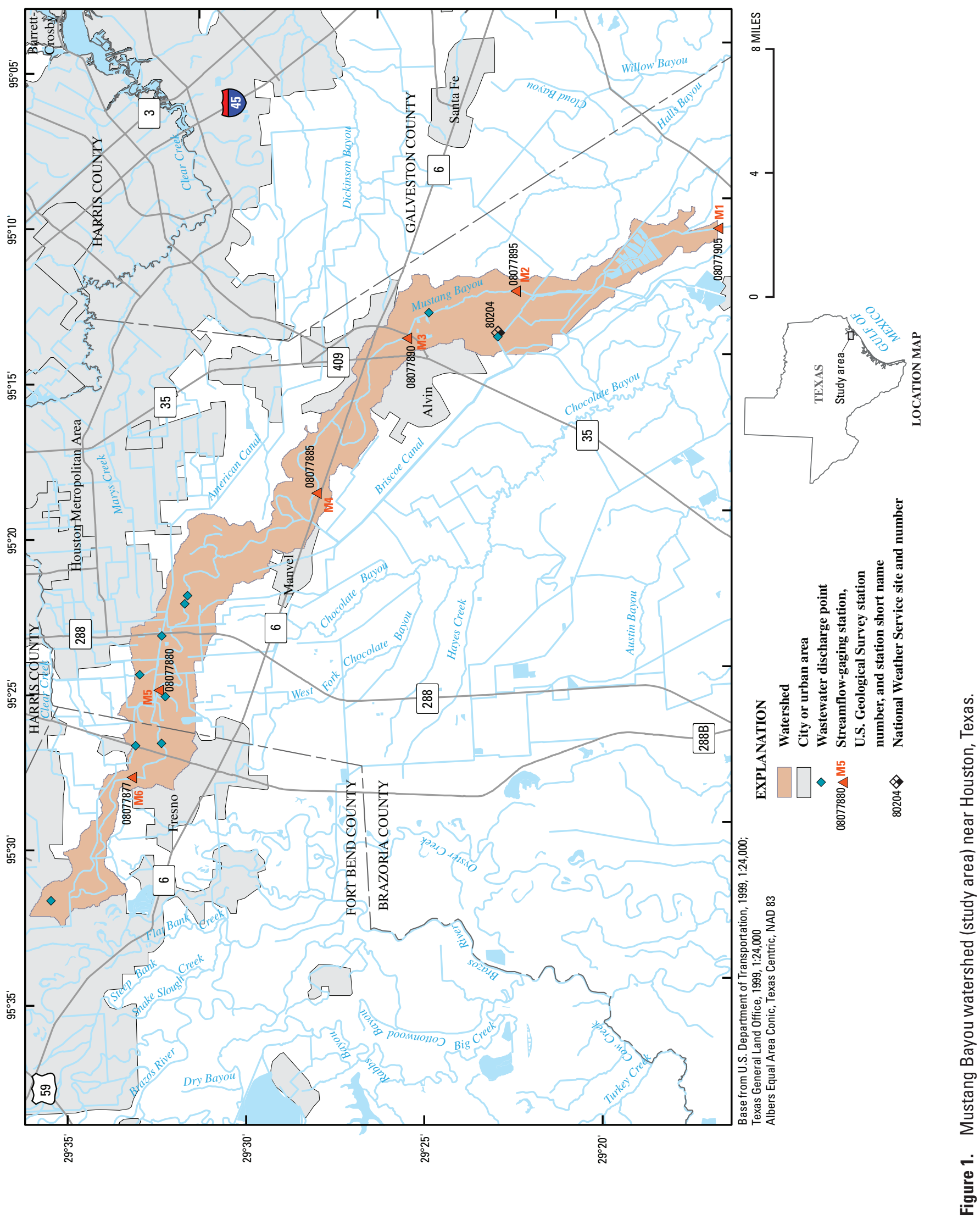



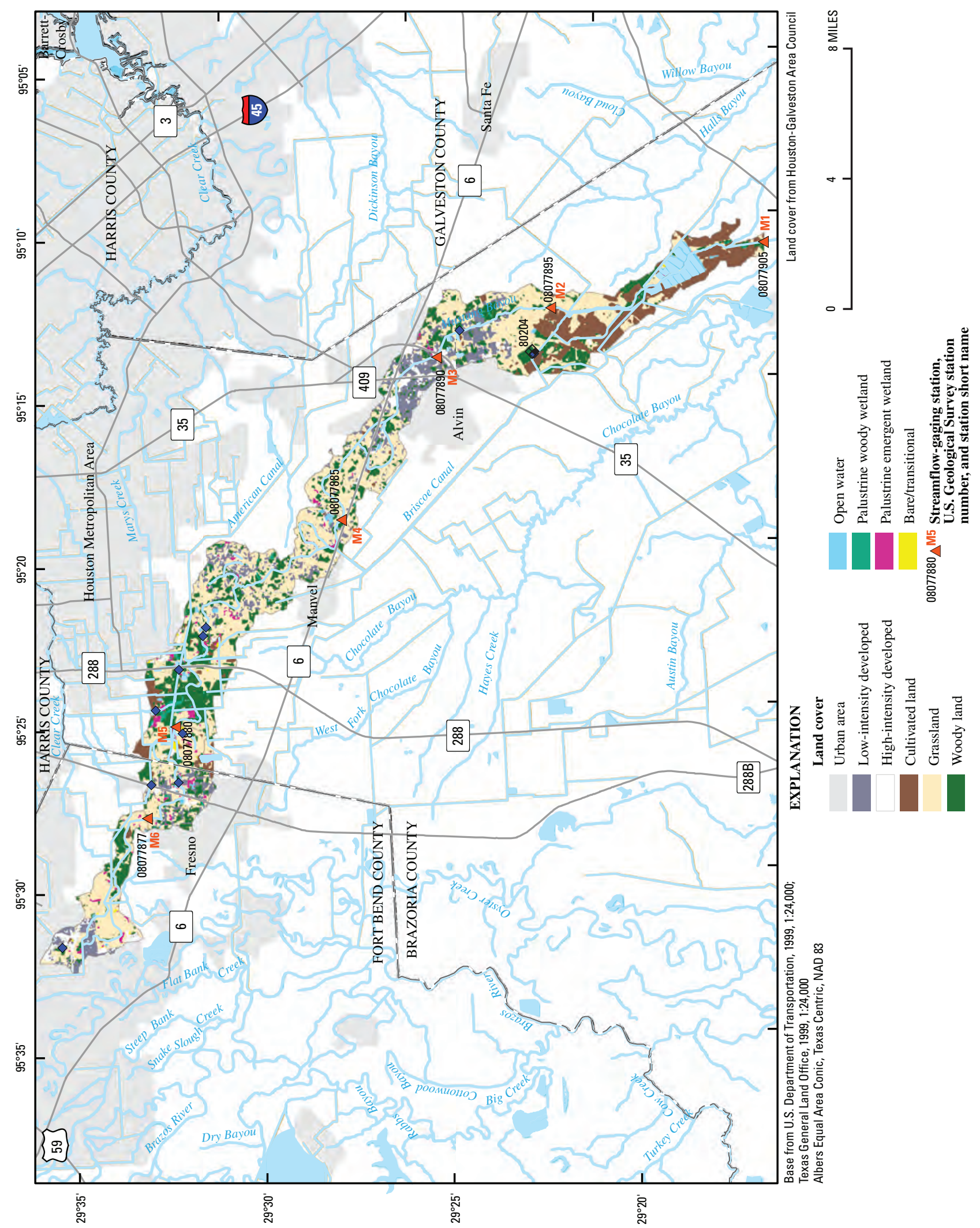

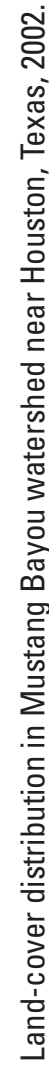

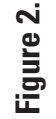




\section{Acknowledgments}

The authors acknowledge the contribution of Jean Wright (Houston-Galveston Area Council), who assisted with the Quality Assurance Project Plan (QAPP) and project planning; and Patrick Horton (Houston-Galveston Area Council), who provided geographic information system feature datasets of the watershed.

\section{Water-Quality Data}

Water-quality data were collected to identify differences in physiochemical conditions among six sampling sites on Mustang Bayou (fig. 1; table 1). Data were grouped by (1) continuous water-quality-monitoring data-properties measured with a multiprobe instrument deployed at each site; and (2) water-sampling data-properties and constituents determined from periodically collected samples.

\section{Continuously Monitored Water-Quality Properties}

Instream, continuous data were used to characterize diurnal fluctuations in water-quality conditions in Mustang Bayou. Multiprobe, water-quality monitors were deployed at six sites for a minimum of 24 hours to several days in September 2004, and January, April, June, July, and August 2005. At each site, monitors were deployed at sites that were typical of depth and flow conditions of the stream reach used for biological data collection. Instream water temperature, $\mathrm{pH}$, specific conductance, and dissolved oxygen were measured and logged by the monitor every 15 minutes.

Measured water temperatures (table 2) ranged from a minimum of 14.4 degrees Celsius $\left({ }^{\circ} \mathrm{C}\right)$ in January 2005 at M2

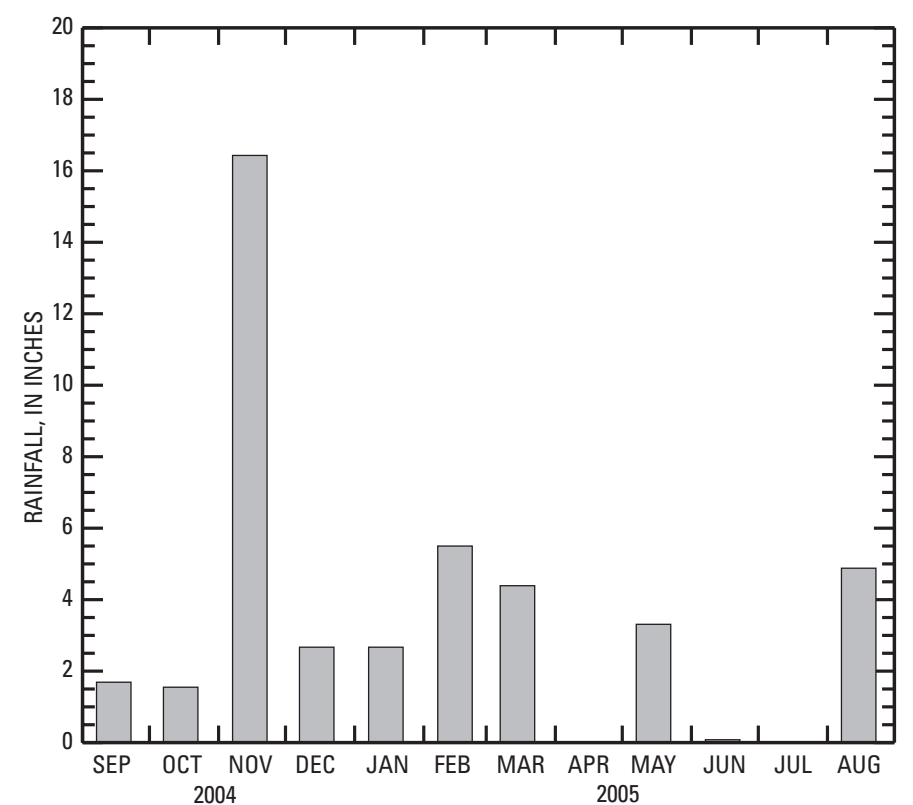

Figure 3. Rainfall at National Weather Service site 80204 (Alvin), September 2004-August 2005 (National Climatic Data Center, 2004, 2005).

to a maximum of $36.8^{\circ} \mathrm{C}$ in August 2005 at M6. The average mean water temperature measured from deployments during June-August 2005 for all stations was $27.4{ }^{\circ} \mathrm{C}$. Median $\mathrm{pH}$ values (table 3 ) from all sites varied from 6.9 to 8.0 standard units. The maximum $\mathrm{pH}$ of 8.8 standard units was measured at M4 in August 2005. The minimum pH was 6.8 standard units at M5 in September 2004. Specific conductance (table 4) generally was lower at upstream sites, M5 and M6, than at downstream sites. For all sites, values ranged from 372 microsiemens per centimeter at $25{ }^{\circ} \mathrm{C}(\mu \mathrm{S} / \mathrm{cm})$ at $\mathrm{M} 3$ to 2,050 $\mu \mathrm{S} / \mathrm{cm}$ at M4. Because available specific conductance data

Table 1. Data-collection sites in Mustang Bayou near Houston, Texas, September 2004-August 2005.

[USGS, U.S. Geological Survey; TCEQ, Texas Commission on Environmental Quality; FM, Farm Road; CR, County Road]

\begin{tabular}{cccccc}
\hline $\begin{array}{c}\text { Station } \\
\text { short name } \\
\text { (fig. 1) }\end{array}$ & $\begin{array}{c}\text { USGS } \\
\text { station } \\
\text { number }\end{array}$ & $\begin{array}{c}\text { TCE0 } \\
\text { station } \\
\text { number }\end{array}$ & Station name & $\begin{array}{c}\text { Drainage } \\
\text { area } \\
\text { (square miles) }\end{array}$ & $\begin{array}{c}\text { Altitude } \\
\text { (feet above } \\
\text { NGVD 29) }\end{array}$ \\
\hline${ }^{1}$ M1 & 08077905 & 11423 & Mustang Bayou at FM 2917 near Liverpool, Tex. & 47.1 & 14.1 \\
M2 & 08077895 & 17959 & Mustang Bayou at CR 168 near Alvin, Tex. & 33.4 & 20.0 \\
M3 & 08077890 & 18554 & Mustang Bayou at East South Street at Alvin, Tex. & 27.9 & 38.1 \\
M4 & 08077885 & 18553 & Mustang Bayou at CR 99 near Alvin, Tex. & 20.2 & 45.0 \\
M5 & 08077880 & 18552 & Mustang Bayou at CR 48 near Fresno, Tex. & 9.11 & 60.0 \\
M6 & 08077877 & 18551 & Mustang Bayou at Evergreen Road near Fresno, Tex. & 5.64 & 65.0 \\
\hline
\end{tabular}

${ }^{1}$ Bed sediment samples also collected at this site in September 2005. 
Table 2. Summary of 24-hour water temperature data collected at sites in Mustang Bayou near Houston, Texas, September 2004August 2005.

[--, no value]

\begin{tabular}{|cl|cccccc|}
\hline \multirow{2}{*}{$\begin{array}{c}\text { Station } \\
\text { short name } \\
\text { (fig. 1) }\end{array}$} & Data type & \multicolumn{5}{|c|}{$\begin{array}{c}\text { Measured water temperature } \\
\text { (degrees Celsius) }\end{array}$} \\
\cline { 3 - 8 } & & Sept. & Jan. & Apr. & June & July & Aug. \\
\hline M1 & Maximum & 2004 & $\mathbf{2 0 0 5}$ & $\mathbf{2 0 0 5}$ & $\mathbf{2 0 0 5}$ & $\mathbf{2 0 0 5}$ & $\mathbf{2 0 0 5}$ \\
& Minimum & 28.2 & 20.3 & 25.0 & 31.5 & 32.6 & 34.1 \\
& Mean & 27.2 & 14.8 & 18.9 & 27.9 & 29.2 & 30.1 \\
M2 & Maximum & 32.9 & 16.7 & 22.8 & 29.4 & 30.8 & 32.0 \\
& Minimum & 28.0 & 18.2 & 26.2 & -- & 31.3 & 34.0 \\
& Mean & 30.2 & 16.4 & 21.1 & -- & 28.5 & 29.7 \\
M3 & Maximum & 34.2 & 20.0 & 23.4 & -- & 29.7 & 31.6 \\
& Minimum & 27.0 & 15.2 & 27.0 & 33.2 & 30.6 & 34.4 \\
& Mean & 30.2 & 17.1 & 23.5 & 28.1 & 28.4 & 29.9 \\
M4 & Maximum & 32.2 & 23.3 & 28.9 & 30.1 & 29.6 & 31.8 \\
& Minimum & 27.5 & 20.8 & 19.8 & 26.4 & 34.6 & 35.0 \\
& Mean & 29.4 & 21.8 & 23.8 & 28.7 & 32.0 & 28.6 \\
M5 & Maximum & 29.9 & 21.9 & 27.4 & -- & 32.0 & 31.7 \\
& Minimum & 25.6 & 20.9 & 20.4 & -- & 29.2 & 29.2 \\
& Mean & 27.4 & 21.3 & 23.6 & -- & 30.6 & 30.7 \\
M6 & Maximum & -- & 22.2 & 30.2 & 33.7 & 35.1 & 36.8 \\
& Minimum & -- & 20.0 & 16.4 & 24.5 & 28.0 & 27.0 \\
& Mean & -- & 21.0 & 22.4 & 28.5 & 31.3 & 31.6 \\
\hline
\end{tabular}

reflect only small periods during the year, the true extent of tidal influence, which includes specific conductance equal to or greater than $3,077 \mu \mathrm{S} / \mathrm{cm}$ (Texas Commission on Environmental Quality, 2003a), could not be determined. However, because of the proximity of M1 to the Gulf coast, the fluctuation of water levels caused by tidal activity, and the persistence of saltwater fish collected at the site, water-quality criteria applicable to saltwater are used for this site.

Dissolved oxygen is a primary component used to evaluate the suitability of a stream to sustain aquatic life. Fish that are intolerant of low levels of oxygen become stressed when concentrations of dissolved oxygen are less than about 5 milligrams per liter $(\mathrm{mg} / \mathrm{L})$. At concentrations less than 2 $\mathrm{mg} / \mathrm{L}$, fish kills can result (Fram, 2006). To maintain dissolved oxygen levels that will support fish, the Texas Commission on Environmental Quality (2003a) has established mean and minimum criteria for dissolved oxygen levels in natural waters, depending on the type of stream (freshwater, M2-M5; intermittent, M6; and tidal, M1) (table 5). The 24-hour mean dissolved oxygen criteria is $5.0 \mathrm{mg} / \mathrm{L}$ for perennial freshwater streams, $3.0 \mathrm{mg} / \mathrm{L}$ for intermittent streams, and 4.0 for tidally influenced streams. The minimum criteria is $3.0 \mathrm{mg} / \mathrm{L}$ for perennial freshwater and tidally influenced streams and 2.0 $\mathrm{mg} / \mathrm{L}$ for intermittent streams.
Mean dissolved oxygen concentrations from Mustang Bayou (table 5) were less than the 24-hour mean dissolved oxygen criteria in at least one monitoring period at all sites except M2. Minimum dissolved oxygen concentrations were less than the minimum criteria 40 to 67 percent of the time at all sites except M2. The lowest concentrations of dissolved oxygen were measured in July and August when water temperatures exceeded $30{ }^{\circ} \mathrm{C}$ and measured streamflows generally were low. Graphed concentrations of dissolved oxygen for M4 and M5 in August 2005 show a diurnal pattern in which concentrations are less than minimum criteria about 25 percent of each day at M4 and 50 percent of each day at M5 (fig. 4).

\section{Periodically Collected Water-Quality Properties and Constituents}

Eight discrete water samples were collected at each site. Before sample collection, water temperature, $\mathrm{pH}$, specific conductance, and dissolved oxygen data were collected at three sections in the stream to determine uniformity of physical conditions across the channel. Water (grab) samples were collected at the center of the stream using methods described in a Texas Natural Resource Conservation Commission (1999b) 
Table 3. Summary of 24-hour pH data collected at sites in Mustang Bayou near Houston, Texas, September 2004-August 2005. $[--$, no value $]$

\begin{tabular}{|cl|cccccc|}
\hline \multirow{2}{*}{$\begin{array}{c}\text { Station } \\
\text { short name } \\
\text { (fig. 1) }\end{array}$} & Data type & \multicolumn{5}{|c|}{$\begin{array}{c}\text { Measured pH } \\
\text { (standard units) }\end{array}$} \\
\cline { 3 - 8 } & & Sept. & Jan. & Apr. & June & July & Aug. \\
\hline M1 & Maximum & $\mathbf{2 0 0 4}$ & $\mathbf{2 0 0 5}$ & $\mathbf{2 0 0 5}$ & $\mathbf{2 0 0 5}$ & $\mathbf{2 0 0 5}$ & $\mathbf{2 0 0 5}$ \\
& Minimum & 7.7 & 8.1 & 8.5 & 8.2 & 8.0 & 8.1 \\
& Median & 7.5 & 7.8 & 7.4 & 7.4 & 7.3 & 7.0 \\
& Maximum & 8.6 & 8.0 & 8.0 & 7.6 & 7.6 & 7.2 \\
\hline M2 & Minimum & 7.6 & 7.9 & 8.2 & -- & 7.9 & 8.0 \\
& Median & 7.8 & 7.7 & 7.5 & -- & 7.5 & 7.3 \\
& Maximum & 8.5 & 7.8 & 7.8 & -- & 7.6 & 7.5 \\
\hline M3 & Minimum & 7.4 & 7.6 & 7.0 & 8.1 & 7.5 & 7.7 \\
& Median & 7.9 & 7.7 & 7.5 & 7.3 & 7.3 & 7.3 \\
& Maximum & 7.8 & 8.2 & 8.3 & 8.1 & 8.2 & 8.8 \\
\hline M4 & Minimum & 7.4 & 7.7 & 7.6 & 7.3 & 7.2 & 7.3 \\
& Median & 7.5 & 7.8 & 7.8 & 7.5 & 7.5 & 7.9 \\
\hline M5 & Maximum & 7.2 & 7.8 & 8.3 & -- & 7.7 & 8.0 \\
& Minimum & 6.8 & 7.7 & 7.6 & -- & 7.3 & 7.1 \\
& Median & 6.9 & 7.8 & 7.8 & -- & 7.5 & 7.3 \\
\hline M6 & Maximum & -- & 7.7 & 8.3 & 8.6 & 7.8 & 8.0 \\
& Minimum & -- & 7.3 & 7.3 & 7.0 & 7.1 & 7.1 \\
& Median & -- & 7.5 & 7.8 & 7.2 & 7.4 & 7.4 \\
\hline
\end{tabular}

procedures manual. All chemical and biological samples were maintained at less than $4{ }^{\circ} \mathrm{C}$ until analysis. Thirty-one physical properties, chemical constituents, and biological constituents were measured from each water sample. Concentrations of 52 soluble pesticide compounds were measured in four of the eight water samples from each site (appendix 1). Water-quality constituents quantified in laboratory analyses were

1. Nutrients (total nitrogen, organic nitrogen, ammonia plus organic nitrogen, ammonia nitrogen, nitrite plus nitrate nitrogen, nitrite nitrogen, nitrate nitrogen, orthophosphate phosphorus, total phosphorus)

2. Biochemical oxygen demand (BOD) and carbonaceous biochemical oxygen demand (CBOD)

3. Phytoplankton (pheophytin, chlorophyll- $a$ )

4. E. coli fecal indicator bacteria

5. Chloride and sulfate

6. Suspended and dissolved solids

7. Suspended sediment concentration

8. Pesticides
Analyses for BOD, CBOD, and fecal indicator bacteria (Myers and Wilde, 2003) were done at the USGS Texas Water Science Center Gulf Coast Program office. Suspended sediment concentrations were analyzed (Guy, 1969) at the USGS Louisiana Water Science Center Sediment Laboratory. All other analyses were done at the USGS National Water Quality Laboratory (NWQL) in Denver, Colo., using methods described in Fishman and Friedman (1989), Patton and Truitt (1992; 2000), Fishman (1993), Zaugg and others (1995), Lindley and others (1996), Sandstrom and others (2001), and Madsen and others (2003).

Concentrations of selected water-quality constituents (nutrients, BOD, chlorophyll- $a, E$. coli, chloride, sulfate, suspended solids, dissolved solids, and selected pesticides) were compared among the six sites (figs. 5-8). For some of these constituents, the TCEQ has developed screening levels to identify secondary concerns (table 6) in streams for which water-quality standards have not been adopted (Texas Commission on Environmental Quality, 2003a). Although screening levels do not represent State criteria, exceedances of those levels might indicate a potential water-quality concern. E. coli densities are used to evaluate whether a primary concern exists for contact and noncontact recreation. The singlesample water-quality standard for E. coli is 394 colonies per 
Table 4. Summary of 24-hour specific conductance data collected at sites in Mustang Bayou near Houston, Texas, September 2004-August 2005.

$[--$, no value $]$

\begin{tabular}{|cl|cccccc|}
\hline \multirow{2}{*}{$\begin{array}{c}\text { Station } \\
\text { short name } \\
\text { (fig. 1) }\end{array}$} & Data type & \multicolumn{5}{|c|}{$\begin{array}{c}\text { Measured specific conductance } \\
\text { (microsiemens per centimeter at 25 degrees Celsius) }\end{array}$} \\
\cline { 3 - 8 } & & Sept. & Jan. & Apr. & June & July & Aug. \\
\hline M1 & Maximum & 9004 & $\mathbf{2 0 0 5}$ & $\mathbf{2 0 0 5}$ & $\mathbf{2 0 0 5}$ & $\mathbf{2 0 0 5}$ & $\mathbf{2 0 0 5}$ \\
\hline & Minimum & 887 & 1,250 & 1,130 & 951 & 503 & 589 \\
& Mean & 907 & 1,200 & 1,060 & 844 & 472 & 523 \\
\hline M2 & Maximum & 668 & 1,220 & 1,100 & 887 & 483 & 557 \\
\hline & Minimum & 625 & 1,170 & 1,490 & -- & 529 & 455 \\
& Mean & 645 & 1,220 & 1,070 & -- & 424 & 393 \\
\hline M3 & Maximum & 653 & 1,390 & 1,610 & 829 & 461 & 516 \\
& Minimum & 571 & 1,290 & 1,170 & 700 & 372 & 389 \\
& Mean & 616 & 1,350 & 1,350 & 763 & 438 & 457 \\
\hline M4 & Maximum & 638 & 1,590 & 2,050 & 836 & 659 & 532 \\
& Minimum & 592 & 1,560 & 1,820 & 756 & 629 & 447 \\
& Mean & 611 & 1,580 & 1,930 & 787 & 645 & 497 \\
\hline M5 & Maximum & 531 & 769 & 707 & -- & 658 & 575 \\
& Minimum & 496 & 614 & 661 & -- & 501 & 533 \\
& Mean & 511 & 688 & 691 & -- & 563 & 550 \\
\hline M6 & Maximum & -- & 410 & 772 & -- & 843 & 478 \\
& Minimum & -- & 384 & 664 & -- & 829 & 446 \\
& Mean & -- & 398 & 712 & -- & 837 & 464 \\
\hline
\end{tabular}

100 milliliters (cols./100 mL) (Texas Commission on Environmental Quality (2003a).

\section{Nutrients}

Distributions of ammonia nitrogen, ammonia plus organic nitrogen, nitrite nitrogen, nitrite plus nitrate nitrogen, orthophosphate phosphorus, and total phosphorus are shown in figure 5. Screening levels were not exceeded in any sample.

Nitrogen compounds naturally occur in the environment, usually in small amounts in surface water, and include ammonia, organic nitrogen, nitrite, and nitrate. The largest concentration of ammonia was $0.21 \mathrm{mg} / \mathrm{L}$, measured at M1 (fig. 5A). The median concentration from all sites combined was 0.04 $\mathrm{mg} / \mathrm{L}$. The largest ammonia plus organic nitrogen concentration $(2.8 \mathrm{mg} / \mathrm{L})$ was measured at M6 (fig. 5B). Of this amount, organic nitrogen was computed to be $2.7 \mathrm{mg} / \mathrm{L}$. Computations, subtracting ammonia concentrations from ammonia plus organic nitrogen concentrations, showed that organic nitrogen contributed between about 85 to 95 percent of the concentration of ammonia plus organic nitrogen measured at all sites. The median ammonia plus organic nitrogen concentration from all samples was $0.46 \mathrm{mg} / \mathrm{L}$. Nitrite concentrations in Mustang Bayou (fig. 5C) ranged from $0.001 \mathrm{mg} / \mathrm{L}$ at M1 and M4-M6 to $0.072 \mathrm{mg} / \mathrm{L}$ at M1. The median nitrite concentration was $0.004 \mathrm{mg} / \mathrm{L}$. Nitrite plus nitrate concentrations (fig. $5 \mathrm{D})$ ranged from less than or the reporting level $(0.016 \mathrm{mg} / \mathrm{L})$ at all sites to a maximum concentration of $0.67 \mathrm{mg} / \mathrm{L}$ at M1. The median nitrite plus nitrate concentration from all sites combined was $0.024 \mathrm{mg} / \mathrm{L}$. Computations, subtracting nitrite concentrations from nitrite plus nitrate concentrations, showed that nitrate contributed about 85 to 92 percent to the combined concentration.

Total phosphorus includes dissolved forms as well as phosphorus attached to sediment particles and in living organisms like algae and bacteria. Phosphorus can be introduced to the water through a variety of sources that include animal waste, domestic and wild waterfowl, tree leaves, and fallout from the atmosphere. Orthophosphate is an inorganic form of phosphorus that is used by plants. It is produced by natural processes and also is found in sewage (Hem, 1985). Orthophosphate concentrations (fig. 5E) were largest at M1 with a maximum concentration of $0.341 \mathrm{mg} / \mathrm{L}$. Maximum concentrations at the remaining sites were less than $0.1 \mathrm{mg} / \mathrm{L}$. The 


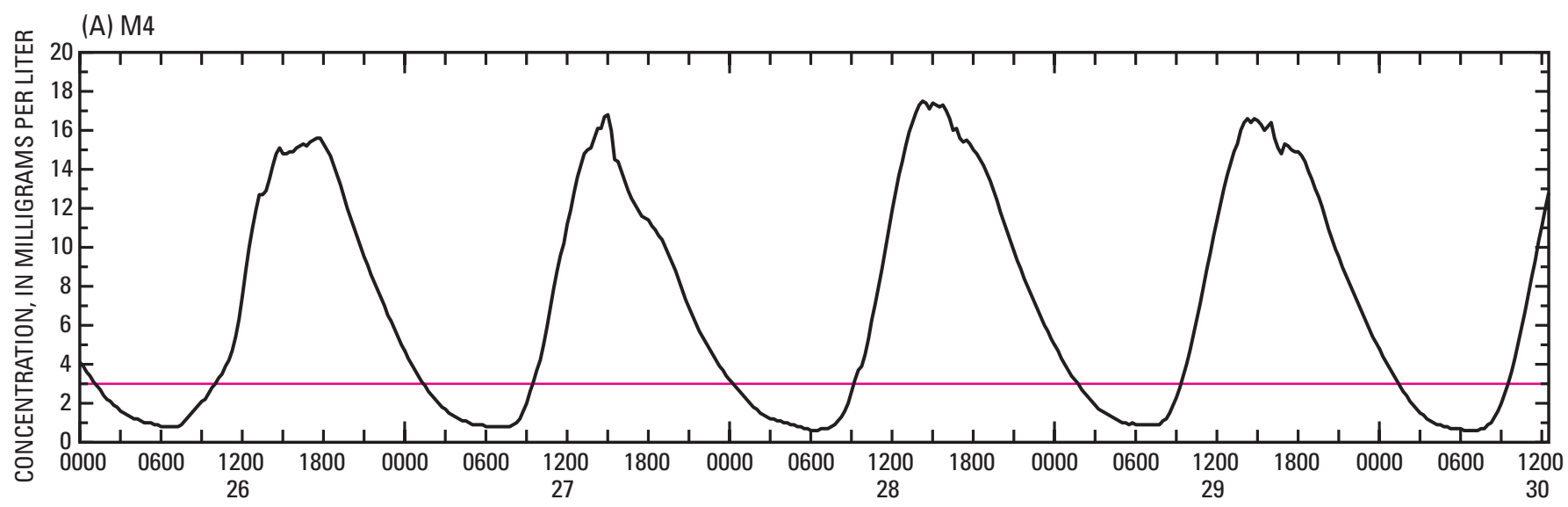

(B) M5

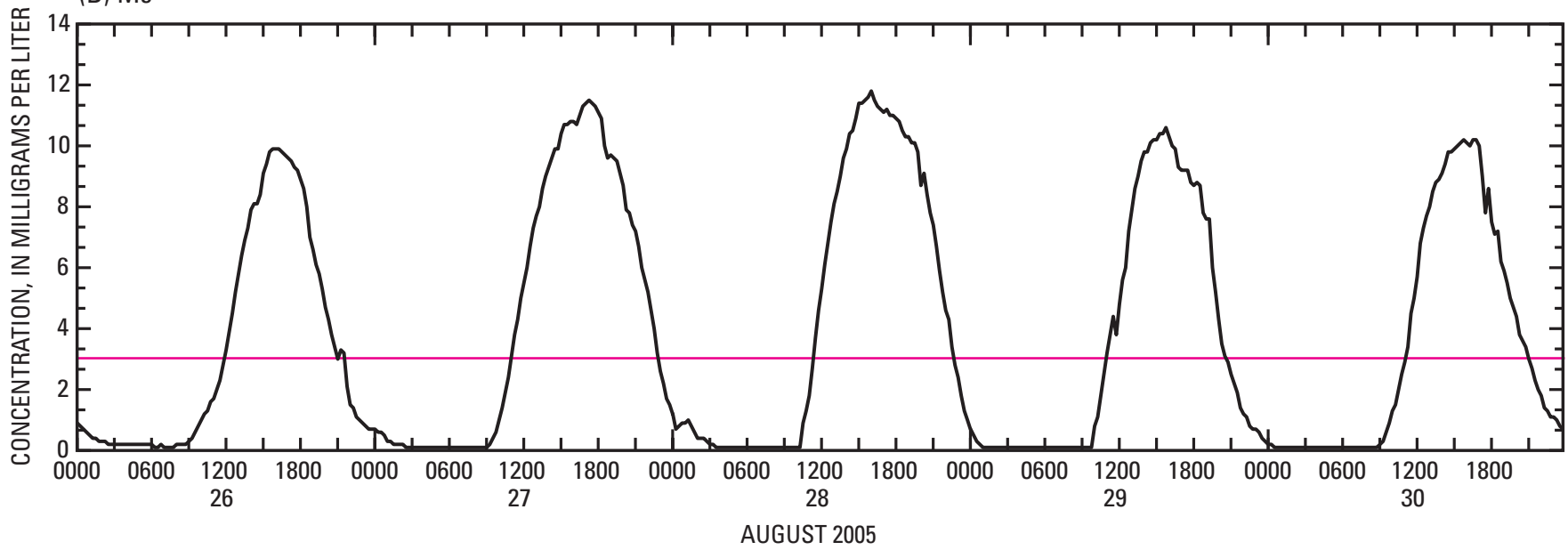

EXPLANATION

Minimum dissolved oxygen criteria (Texas Commission on Environmental Quality (2003a, p. 27)

Figure 4. Diurnal dissolved oxygen concentrations at sites (A) M4, Mustang Bayou at County Road 99 near Alvin, and (B) M5, Mustang Bayou at County Road 48 near Fresno, August 2005.

median orthophosphate concentration for all samples from Mustang Bayou was $0.042 \mathrm{mg} / \mathrm{L}$. The contribution of orthophosphate to the total phosphorus concentration ranged from about 4 percent at M6 to 72 percent at M1. Total phosphorus concentrations (fig. 5F) were largest at M1; the maximum concentration was $0.45 \mathrm{mg} / \mathrm{L}$. The median total phosphorus concentration from all sites was $0.11 \mathrm{mg} / \mathrm{L}$.

\section{Biochemical Oxygen Demand, Chlorophyll-a, and E. Coli}

BOD is the measure of oxygen consumption by microorganisms during decomposition of organic material. If the BOD of decomposition is large, dissolved oxygen concentrations can decrease to close to zero. BOD concentrations were less than $4.0 \mathrm{mg} / \mathrm{L}$ at all sites except M6 (fig. 6A). At M6, the largest measured BOD $(8.1 \mathrm{mg} / \mathrm{L})$ was in July 2005 , a period when there was zero streamflow. The combination of no flow, high water temperatures, and abundant organic matter at the site might have contributed to elevated BOD concentrations. The median BOD concentration from all samples was 2.0 $\mathrm{mg} / \mathrm{L}$.

Chlorophyll- $a$ is a photosynthetic pigment in algae and other green plants. The concentration of chlorophyll- $a$ is used to estimate the amount of phytoplankton in a water body (Porter and others, 1993). In Mustang Bayou, concentrations of chlorophyll- $a$ were less than the freshwater screening level (11.6 micrograms per liter $[\mu \mathrm{g} / \mathrm{L}])$ at all sites except M6, where four of eight samples exceeded $11.6 \mu \mathrm{g} / \mathrm{L}$ (fig. 6B); all exceedances occurred during the summer (June-September). The maximum chlorophyll- $a$ concentration at M6 was 56.6 $\mu \mathrm{g} / \mathrm{L}$; the median concentration was $8.4 \mu \mathrm{g} / \mathrm{L}$. Median concentrations at the remaining sites ranged from $1.2 \mu \mathrm{g} / \mathrm{L}$ at M5 to $2.6 \mu \mathrm{g} / \mathrm{L}$ at M1. The median concentration from all samples was $1.8 \mu \mathrm{g} / \mathrm{L}$. 
Table 5. Summary of 24-hour dissolved oxygen data collected at sites in Mustang Bayou near Houston, Texas, September 2004-August 2005.

[n/a, not applicable; --, no value]

\begin{tabular}{|c|c|c|c|c|c|c|c|c|c|}
\hline \multirow{2}{*}{$\begin{array}{c}\text { Station } \\
\text { short name } \\
\text { (fig. 1) } \\
\text { (stream type) }\end{array}$} & \multirow{2}{*}{$\begin{array}{l}\text { Data } \\
\text { type }\end{array}$} & \multirow{2}{*}{$\begin{array}{c}\text { Dissolved oxygen } \\
\text { criteria }{ }^{1} \\
\text { (milligrams } \\
\text { per liter) }\end{array}$} & \multicolumn{6}{|c|}{$\begin{array}{l}\text { Measured dissolved oxygen } \\
\text { (milligrams per liter) }\end{array}$} & \multirow{2}{*}{$\begin{array}{c}\text { Number of } \\
\text { deployments } \\
\text { with dissolved } \\
\text { oxygen data } \\
\text { below criteria }\end{array}$} \\
\hline & & & $\begin{array}{l}\text { Sept. } \\
2004\end{array}$ & $\begin{array}{l}\text { Jan. } \\
2005\end{array}$ & $\begin{array}{l}\text { Apr. } \\
2005\end{array}$ & $\begin{array}{l}\text { June } \\
2005\end{array}$ & $\begin{array}{l}\text { July } \\
2005\end{array}$ & $\begin{array}{l}\text { Aug. } \\
2005\end{array}$ & \\
\hline \multirow{2}{*}{$\begin{array}{c}\text { M1 } \\
\text { (tidal) }\end{array}$} & Maximum & $\mathrm{n} / \mathrm{a}$ & 5.3 & 12.2 & 13.1 & 11.1 & 6.2 & 12.4 & $\mathrm{n} / \mathrm{a}$ \\
\hline & Minimum & 3.0 & 2.2 & 7.3 & 3.3 & 2.1 & .2 & .5 & 4 \\
\hline \multirow{3}{*}{$\begin{array}{c}\text { M2 } \\
\text { (freshwater) }\end{array}$} & Maximum & $\mathrm{n} / \mathrm{a}$ & 13.9 & 12.4 & -- & -- & 7.6 & 9.6 & $\mathrm{n} / \mathrm{a}$ \\
\hline & Minimum & 3.0 & 4.4 & 9.0 & -- & -- & 3.8 & 4.1 & 0 \\
\hline & Mean & 5.0 & 8.4 & 10.5 & -- & -- & 5.2 & 6.2 & 0 \\
\hline $\begin{array}{c}\text { M3 } \\
\text { (freshwater) }\end{array}$ & Maximum & $\mathrm{n} / \mathrm{a}$ & 16.0 & 11.4 & 12.7 & 10.1 & 3.4 & 6.1 & $\mathrm{n} / \mathrm{a}$ \\
\hline \multirow{2}{*}{$\begin{array}{c}\text { M4 } \\
\text { (freshwater) }\end{array}$} & Minimum & 3.0 & 2.5 & 6.3 & 4.1 & 0.8 & .2 & .8 & 4 \\
\hline & Mean & 5.0 & 4.7 & 9.7 & 9.0 & 4.9 & 2.7 & 6.7 & 3 \\
\hline \multirow{3}{*}{$\begin{array}{l}\text { M5 } \\
\text { (freshwater) }\end{array}$} & Maximum & $\mathrm{n} / \mathrm{a}$ & 7.4 & 7.8 & 11.0 & -- & 8.7 & 11.5 & $\mathrm{n} / \mathrm{a}$ \\
\hline & Minimum & 3.0 & 2.2 & 5.9 & 6.4 & -- & .2 & .1 & 3 \\
\hline & Mean & 5.0 & 4.1 & 6.7 & 8.5 & -- & 4.2 & 4.4 & 3 \\
\hline \multirow{3}{*}{$\begin{array}{c}\text { M6 } \\
\text { (intermittent) }\end{array}$} & Maximum & $\mathrm{n} / \mathrm{a}$ & -- & 8.9 & 12.8 & 10.8 & 8.2 & 5.6 & $\mathrm{n} / \mathrm{a}$ \\
\hline & Minimum & 2.0 & -- & 4.5 & 4.0 & 2.5 & .6 & .8 & 2 \\
\hline & Mean & 3.0 & -- & 6.8 & 8.2 & 5.9 & 4.4 & 2.9 & 1 \\
\hline
\end{tabular}

${ }^{1}$ Texas Commission on Environmental Quality (2003a, p. 27).

Table 6. Screening levels to identify secondary concerns for selected water-quality constituents and primary standard for contact and noncontact recreation for $E$. coli (Texas Commission on Environmental Quality, 2003a).

[mg/L, milligrams per liter; $\mu \mathrm{g} / \mathrm{L}$, micrograms per liter; cols./100 mL, colonies per 100 milliliters; $\mathrm{n} / \mathrm{a}$, not applicable]

\begin{tabular}{|c|c|c|c|c|c|c|}
\hline \multirow[b]{2}{*}{$\begin{array}{l}\text { Stream } \\
\text { type }\end{array}$} & \multicolumn{5}{|c|}{ Screening level } & \multirow[b]{2}{*}{$\begin{array}{c}\text { Primary standard, } \\
\text { E. coli } \\
\text { (cols./100 mL) }\end{array}$} \\
\hline & $\begin{array}{c}\text { Ammonia nitrogen } \\
(\mathrm{mg} / \mathrm{L})\end{array}$ & $\begin{array}{c}\text { Nitrite plus } \\
\text { nitrate nitrogen } \\
\text { (mg/L) }\end{array}$ & $\begin{array}{c}\text { Orthophosphate } \\
\text { phosphorus } \\
\text { (mg/L) }\end{array}$ & $\begin{array}{c}\text { Total } \\
\text { phosphorus } \\
\text { (mg/L) }\end{array}$ & $\begin{array}{c}\text { Chlorophyll-a } \\
(\mu \mathrm{g} / \mathrm{L})\end{array}$ & \\
\hline Freshwater & 0.17 & 2.76 & 0.50 & 0.80 & 11.6 & 394 \\
\hline
\end{tabular}

E. coli is a fecal-indicator bacteria used to signal the potential presence in water of harmful pathogens that come from warm-blooded animals. E. coli densities exceeded 394 cols./100 mL, the State standard for contact and noncontact recreation, in 20 of 48 samples from Mustang Bayou (fig. 6C). The largest E. coli density (4,000 cols./100 mL) was measured at M6. The largest densities at all sites except M3 came from samples collected during March, when there was increased streamflow from rainfall runoff. At M3, the largest E. coli density was measured in July during low-flow conditions. The median density from all samples was 220 cols./100 mL. Median densities at each site ranged from 69 cols./100 mL at M4 to 1,200 cols./100 mL at M3. 
(A) AMMONIA NITROGEN

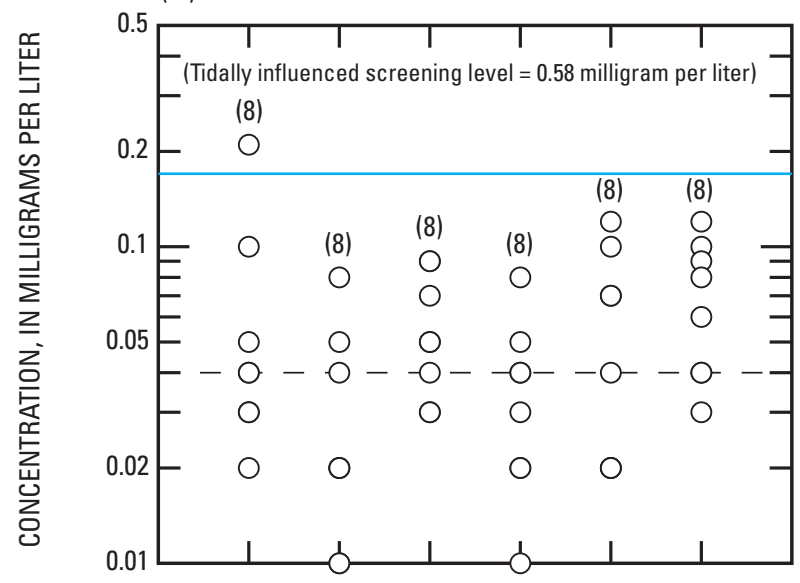

(C) NITRITE NITROGEN

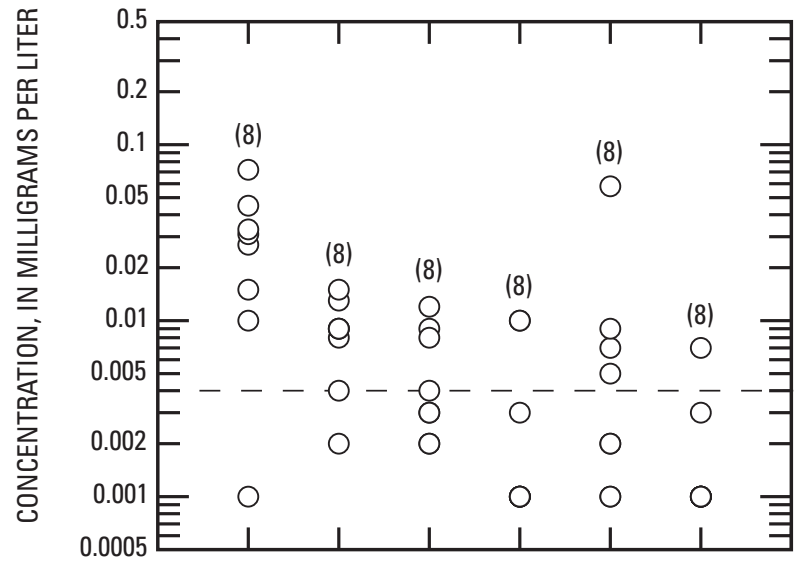

(E) ORTHOPHOSPHATE PHOSPHORUS

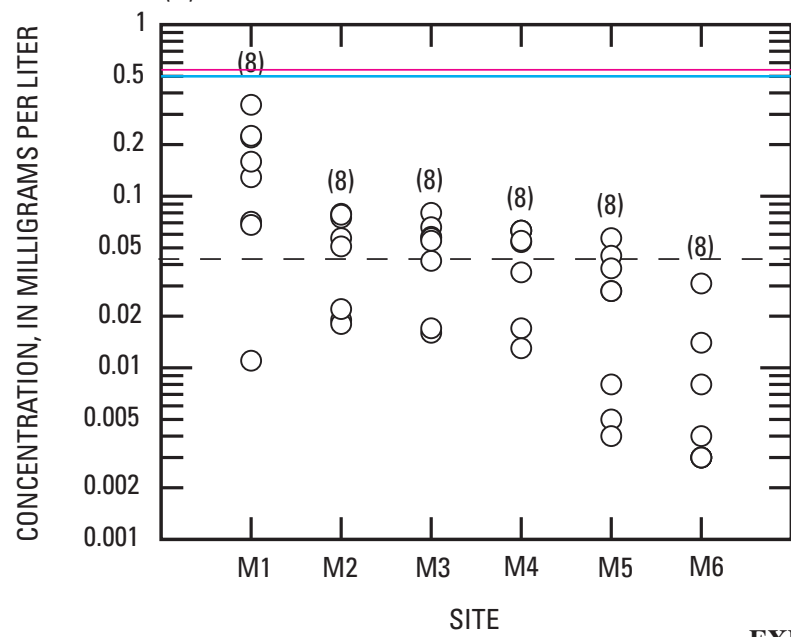

(B) AMMONIA PLUS ORGANIC NITROGEN

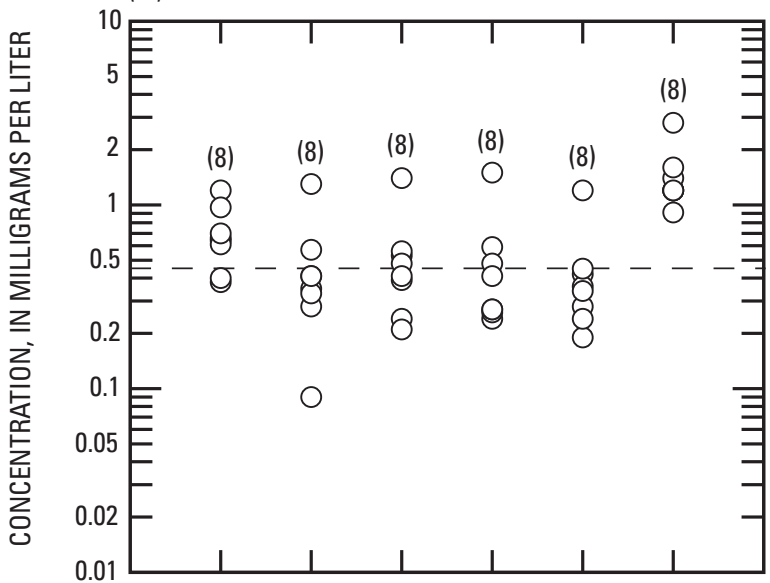

(D) NITRITE PLUS NITRATE NITROGEN

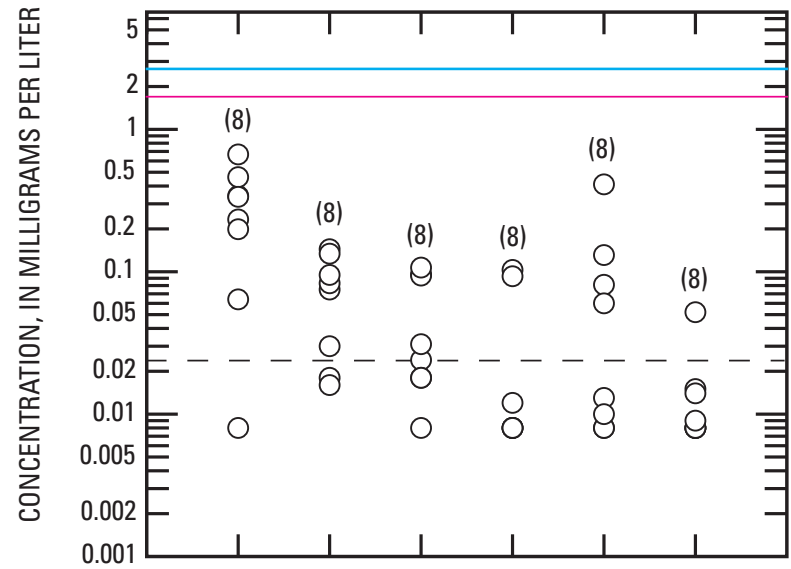

(F) TOTAL PHOSPHORUS

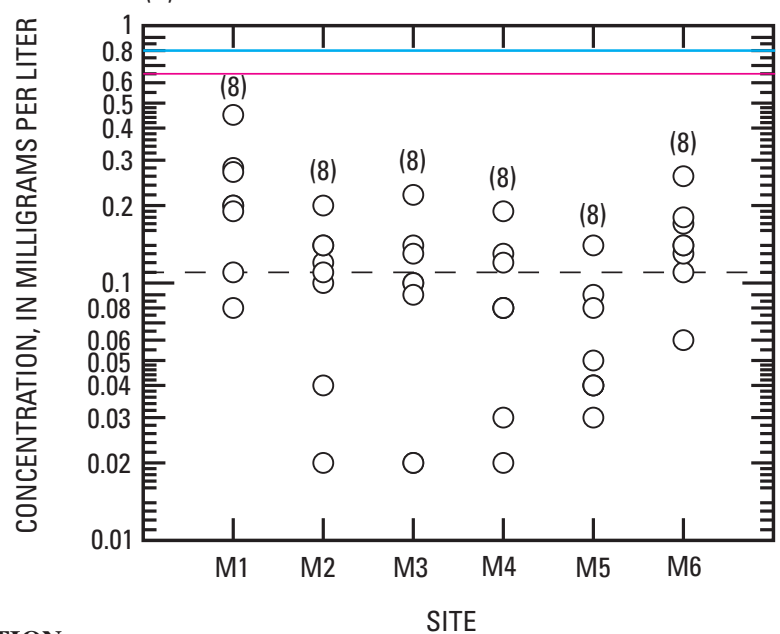

EXPLANATION

(8) Sample size

- - - Median concentration

Tidally influenced screening level

Freshwater screening level

Figure 5. Distribution of (A) ammonia nitrogen, (B) ammonia plus organic nitrogen, (C) nitrite nitrogen, (D) nitrite plus nitrate nitrogen, (E) orthophosphate phosphorus, and (F) total phosphorus concentrations in water samples periodically collected from six sites in Mustang Bayou near Houston, Texas, September 2004-August 2005. 
(A) BIOCHEMICAL OXYGEN DEMAND

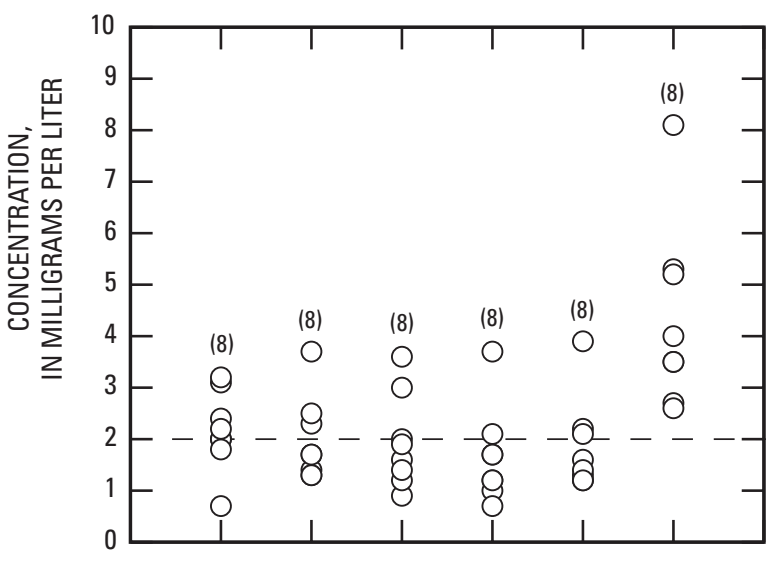

(C) E. COLI

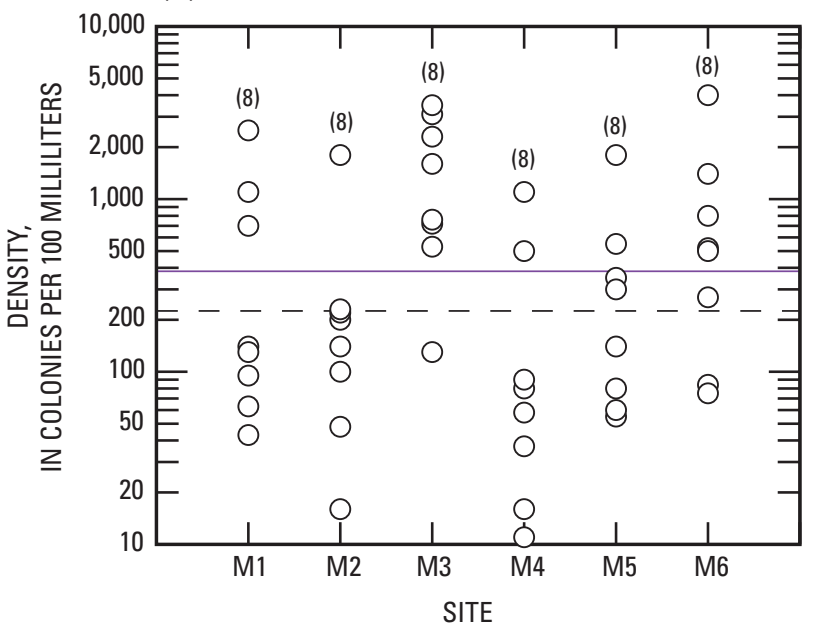

(B) CHLOROPHYLL-A

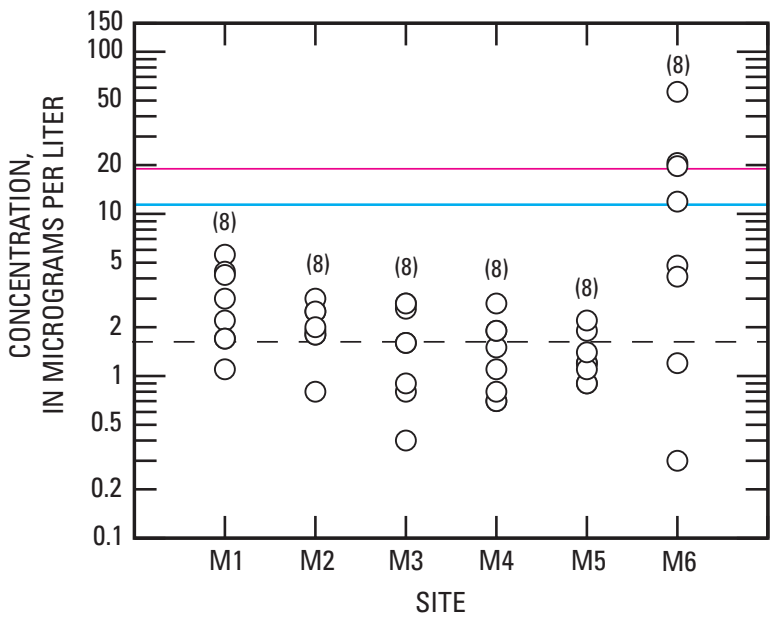

EXPLANATION

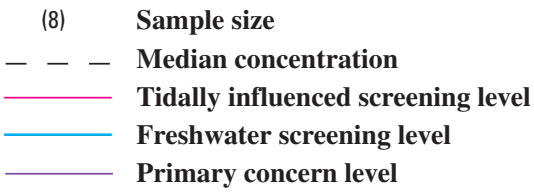

Figure 6. Distribution of (A) biochemical oxygen demand concentrations, (B) chlorophyll-a concentrations, and (C) E. coli densities in water samples periodically collected from six sites in Mustang Bayou near Houston, Texas, September 2004-August 2005.

\section{Chloride, Sulfate, Suspended Solids, and Dissolved Solids}

Chloride, sulfate, suspended solids, and dissolved solids are not used as indicators for the suitability of streams for aquatic life use; however they do provide additional information on the quality of the water for general uses and the aesthetic appeal of a water body. In Mustang Bayou, chloride concentrations reflected the pattern of specific conductance measurements at the sites. The maximum chloride concentration (fig. 7A) was $454 \mathrm{mg} / \mathrm{L}$ at M4. Median chloride concentrations ranged from $42.2 \mathrm{mg} / \mathrm{L}$ at $\mathrm{M} 6$ to $123 \mathrm{mg} / \mathrm{L}$ at $\mathrm{M} 1$. The median chloride concentration from all sites was $69.1 \mathrm{mg} / \mathrm{L}$. Both maximum $(68.4 \mathrm{mg} / \mathrm{L})$ and minimum $(2.7 \mathrm{mg} / \mathrm{L})$ sulfate concentrations were measured at M6 (fig. 7B). Maximum sulfate concentrations were less than $30 \mathrm{mg} / \mathrm{L}$ at all other sites. The median sulfate concentration from all sites at Mustang Bayou was $19.8 \mathrm{mg} / \mathrm{L}$.
The largest concentration of suspended solids was 240 $\mathrm{mg} / \mathrm{L}$ measured at M6 (fig. 7C). Maximum concentrations at all sites except M6 occurred in March during high streamflows (appendix 1). The median concentration of suspended solids from all samples was $16.0 \mathrm{mg} / \mathrm{L}$. The largest concentration of dissolved solids was $1,050 \mathrm{mg} / \mathrm{L}$ measured at M4 (fig. 7D). The median concentration of dissolved solids from all samples was $346 \mathrm{mg} / \mathrm{L}$.

\section{Pesticides}

Fifteen pesticide compounds (six herbicides and nine insecticides) were detected in 24 water samples collected from Mustang Bayou (four samples at each site) (table 7; appendix 1). The most frequently detected herbicides were atrazine (24 detections), 2-chloro-4-isopropylamino-6-amino-s-triazine (CIAT), a degradation product of atrazine (19 detections), prometon (17 detections), and tebuthiuron (17 detections). 
(A) CHLORIDE

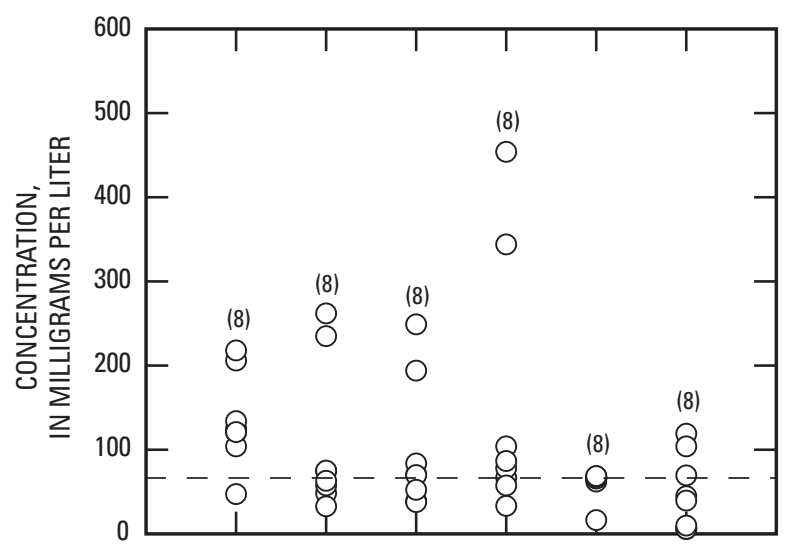

(C) SUSPENDED SOLIDS

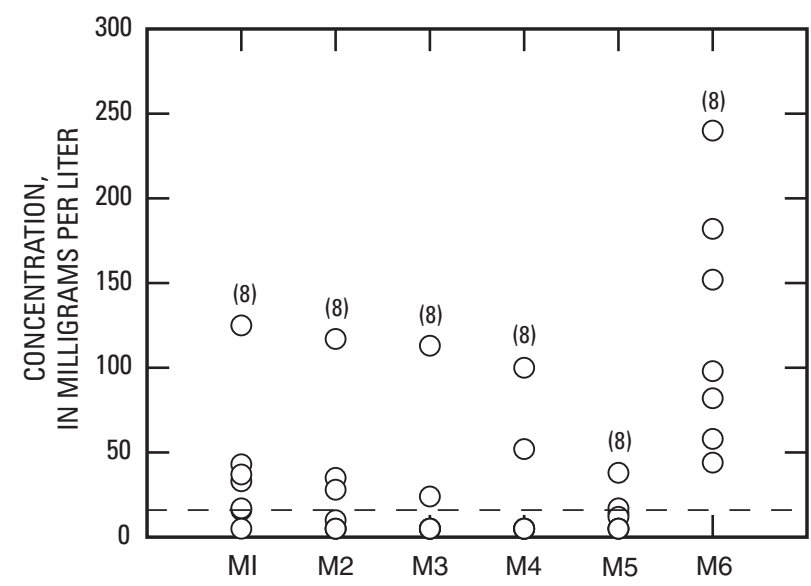

(B) SULFATE

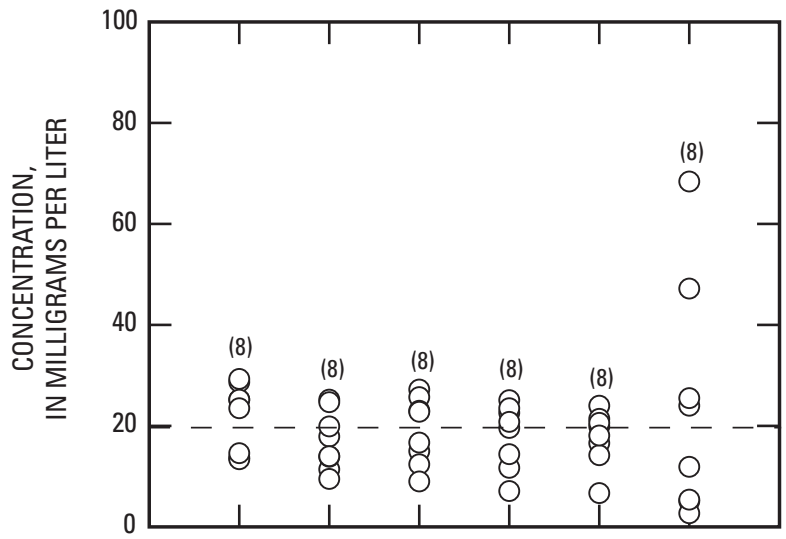

(D) DISSOLVED SOLIDS

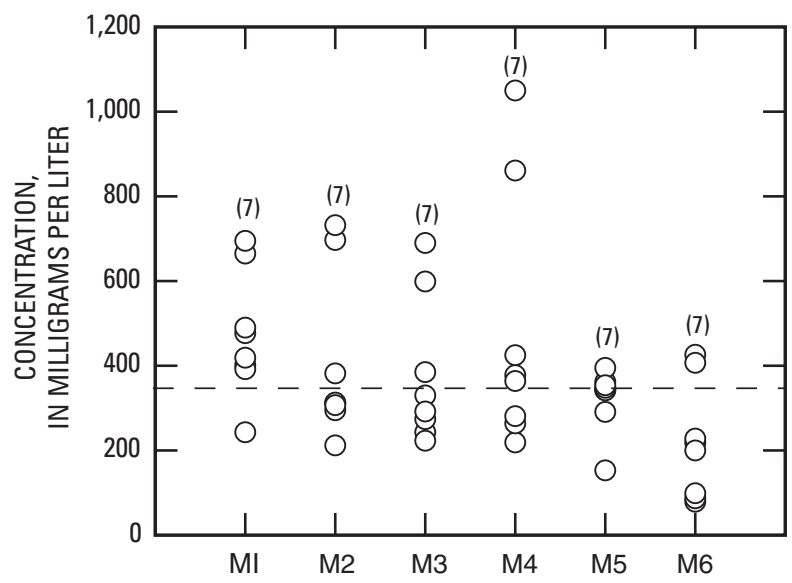

EXPLANATION

(7) Sample size

- - - Median concentration

Figure 7. Distribution of (A) chloride, (B) sulfate, (C) suspended solids, and (D) dissolved solids concentrations in water samples periodically collected from six sites in Mustang Bayou near Houston, Texas, September 2004-August 2005.

The most frequently detected insecticides were fipronil (seven detections) and two of its breakdown products, fipronil sulfide (nine detections) and fipronil sulfone (seven detections). The U.S. Environmental Protection Agency (2004) has established either a maximum contaminant level (MCL) or Health Advisory (HA) for many of these compounds-for atrazine, the $\mathrm{MCL}$ is $3.0 \mu \mathrm{g} / \mathrm{L}$; for prometon, the non-cancer lifetime HA is $100 \mathrm{\mu g} / \mathrm{L}$; for tebuthiuron, the non-cancer lifetime HA is 500 $\mu \mathrm{g} / \mathrm{L}$. No concentrations of any pesticides detected in Mustang Bayou exceeded their respective MCL or HA.

Atrazine is one of the most widely used herbicides in the United States, and it is the most frequently detected herbicide in streams that flow in agricultural areas (U.S. Geological Survey, 1999). Atrazine was detected in every sample; concentrations ranged from $0.010 \mu \mathrm{g} / \mathrm{L}$ to $1.42 \mu \mathrm{g} / \mathrm{L}$, with a median concentration of $0.089 \mu \mathrm{g} / \mathrm{L}$ (fig. 8). Concentrations of CIAT ranged from less than the reporting level $(0.006 \mu \mathrm{g} / \mathrm{L})$ to a maximum concentration of $0.167 \mu \mathrm{g} / \mathrm{L}$ at M6. The median CIAT concentration at all sites was 0.008 $\mu \mathrm{g} / \mathrm{L}$ (fig. 8).

Prometon and tebuthiuron generally are not used for crops but for weed control around structures and roads. Prometon was detected in low concentrations in samples from Mustang Bayou. The maximum concentration was $0.03 \mu \mathrm{g} / \mathrm{L}$ at M2. The median concentration for all samples was at the reporting level $(0.01 \mu \mathrm{g} / \mathrm{L})$ (fig. 8$)$. The maximum concentration of tebuthiuron $(0.09 \mu \mathrm{g} / \mathrm{L})$ was measured at M3. The median concentration for all samples was $0.03 \mu \mathrm{g} / \mathrm{L}$. The detection frequency of tebuthiuron increased downstream from 0 at M6 to 100 percent at M1-M3 (appendix 1). 


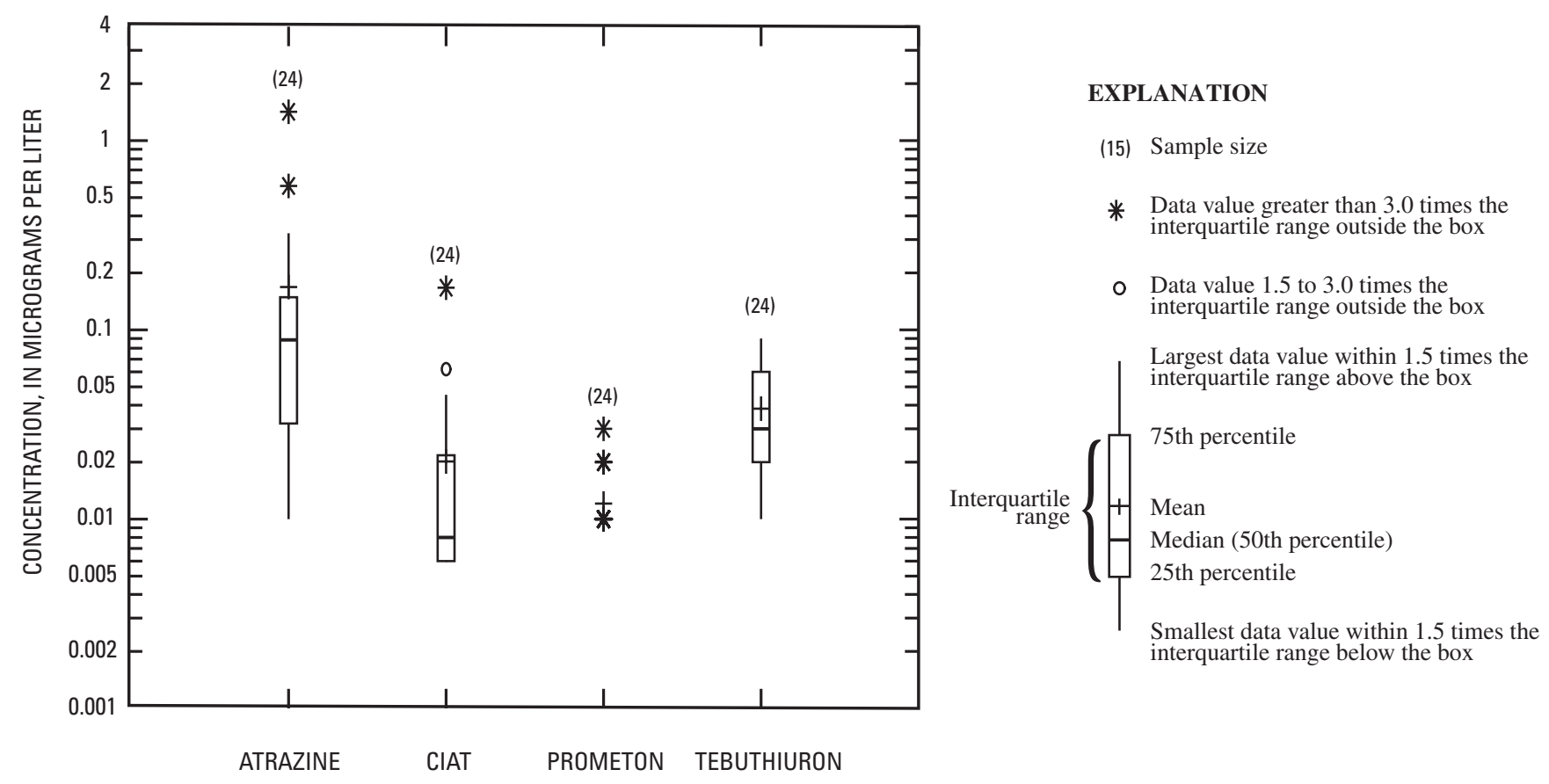

Figure 8. Distribution of selected pesticide concentrations in water samples collected from six sites, combined, in Mustang Bayou near Houston, Texas, September 2004-August 2005.

Table 7. Summary of pesticide detections at sites in Mustang Bayou near Houston, Texas, September 2004-August 2005.

\begin{tabular}{lcccccc}
\hline \multirow{2}{*}{ Compound } & \multicolumn{7}{c}{ Number of detections } \\
\cline { 2 - 7 } & M1 & M2 & M3 & M4 & M5 & M6 \\
\hline Atrazine & 4 & 4 & 4 & 4 & 4 & 4 \\
2-Chloro-4-isopropylamino-6- & 4 & 4 & 3 & 4 & 1 & 3 \\
amino-s-triazine (CIAT) & & & & & & \\
Metolachlor & 1 & 0 & 0 & 0 & 0 & 1 \\
Prometon & 2 & 4 & 2 & 3 & 4 & 2 \\
Simazine & 2 & 1 & 1 & 0 & 1 & 2 \\
Tebuthiuron & 4 & 4 & 4 & 3 & 2 & 0 \\
& Insecticides & & & & \\
Azinphos-methyl & 0 & 0 & 2 & 1 & 0 & 0 \\
Carbaryl & 1 & 0 & 0 & 0 & 0 & 1 \\
Desulfinylfipronil & 2 & 1 & 2 & 0 & 0 & 1 \\
Desulfinylfipronil amide & 2 & 0 & 1 & 0 & 0 & 1 \\
Diazinon & 0 & 0 & 1 & 0 & 0 & 0 \\
Fipronil & 3 & 1 & 2 & 0 & 0 & 1 \\
Fipronil sulfide & 3 & 2 & 2 & 1 & 0 & 1 \\
Fipronil sulfone & 3 & 1 & 2 & 0 & 0 & 1 \\
Malathion & 0 & 0 & 1 & 0 & 1 & 1 \\
\hline
\end{tabular}

Insecticide concentrations in Mustang Bayou were less than $0.1 \mu \mathrm{g} / \mathrm{L}$ (appendix 1). Fipronil was detected in seven of 24 samples (table 7). All concentrations were reported as estimated because of relatively poor recovery of that compound during analysis (Sandstrom and others, 2001). Fipronil was most frequently detected in water samples from M1 (three of four samples) with a maximum concentration of $0.033 \mu \mathrm{g} / \mathrm{L}$ (appendix 1). Fipronil sulfide and fipronil sulfone also were detected in three of four samples from M1. Maximum concentrations of fipronil sulfide $(0.075 \mu \mathrm{g} / \mathrm{L})$ and fipronil sulfone $(0.024 \mu \mathrm{g} / \mathrm{L})$ were measured at M3.

\section{Quality Assurance and Quality Control}

All sample collection and processing procedures, data management, and documentation are described by the Texas Natural Resource Conservation Commission (1999b) and the Texas Commission on Environmental Quality (2003b) and included in the investigation QAPP (Jean Wright, HoustonGalveston Area Council, written commun., 2005).

Quality-control (QC) samples consisting of a field blank, a matrix spike, and replicates (appendix 2) were used to evaluate the extent to which contamination, characteristics of the water (matrix), and measurement variability affected analytical results (Mueller and others, 1997). About 17 percent of the water samples collected were QC samples. Further explanation of QC sample types and their usage are described in Mueller and others (1997). 
One field blank was collected and processed at the site, immediately before the associated environmental sample, to identify potential contamination from field activities associated with data collection. No concentrations of any constituent exceeded the minimum reporting level for that constituent. One water sample was spiked with known volumes and concentrations of pesticide compounds. Laboratory recoveries from the matrix-spike sample were within method-acceptance ranges for all constituents. Additional water was collected seven times during the study to split into two samples; one was designated the environmental sample and the other a split replicate of that sample. Analytical results from each sample set were compared by computing the relative percentage difference (RPD) for each constituent. The RPD, specified for this project in the QAPP, was 20 percent and was computed using the equation

$$
R P D=\left|\mathrm{S}_{1}-\mathrm{S}_{2}\right| /\left[\left(\mathrm{S}_{1}+\mathrm{S}_{2}\right) / 2\right] \times 100
$$

where

$\mathrm{S}_{1}=$ concentration from environmental sample; and

$\mathrm{S}_{2}=$ concentration from replicate sample.

The RPD exceeded 20 percent for one of six sample pairs of turbidity; one of six sample pairs of E. coli; three of seven sample pairs of chlorophyll- $a$, three of seven sample pairs of pheophytin- $a$, one of seven sample pairs of ammonia, two of six sample pairs of suspended solids, and two of six sample pairs of suspended sediment. The RPD exceeded 20 percent for ammonia when constituent concentrations were very low so that even small variability in analytical results caused relatively large RPDs. Most exceedances occurred for biological and sediment-related constituents. Because of inherent heterogeneity of these constituents in water, sample processing, and laboratory analysis, differences in concentrations caused by sampling imprecision (field) or analytical procedures and instrumentation (laboratory) generally were inseparable.

\section{Sediment-Quality Data}

Sediment was collected from the stream bottom at M1 using methods described by Radtke (1997) and the Texas Commission on Environmental Quality (2003b). An alternative method of sample collection, large-volume suspended-sediment sampling (Mahler and Van Metre, 2003), was attempted at this site. However, flat topography, low water velocities, and tidal fluctuations at the site made it impossible to collect suspended sediment from high flows. Water temperature, $\mathrm{pH}$, specific conductance, and dissolved oxygen were collected with the samples to characterize water conditions of the overlying water column. The top 1 centimeter of sediment was retained from several subsamples to capture the most recently deposited material. Analyses to determine concentrations of 62 selected organochlorine pesticides, polycyclic aromatic hydrocarbons (PAHs), trace elements (metals), and polychlorinated biphenyls (PCBs) in the streambed sediment (appendix 3) were completed at the USGS NWQL (Fishman and Friedman, 1989; Garbarino and Struzeski, 1998; U.S. Environmental Protection Agency, 1998; Noriega and others, 2004; Olson and others, 2004).

The Texas Commission on Environmental Quality (2003a) has established guidelines to assess the toxicity of sediment in streams. No organochlorine pesticides or PCBs were detected. No concentrations of metals exceeded State screening levels. Eleven PAH compounds were detected at measurable concentrations, and three other PAH compounds were detected but not quantified by the laboratory. All concentrations were less than respective sediment-quality screening levels. Analytical results are presented in appendix 3.

\section{Habitat Data}

Stream-habitat data were collected at each of the six sites three times during the study, in September 2004, April 2005, and August 2005. A representative stream reach was selected at each site (Texas Natural Resource Conservation Commission, 1999b). Within this reach, five evenly spaced stream transects were identified. At each transect, stream-channel attributes (for example, wetted channel width, water depths, bottom materials, instream cover) and riparian attributes (bank slope and erosion potential, width of natural vegetation, types of vegetation, percentage tree canopy) were measured. The number of stream bends and riffles and the overall aesthetic condition also were noted. A habitat quality index (HQI) was computed for each site using aquatic-life-use scoring described by the Texas Commission on Environmental Quality (2003a).

Mustang Bayou has been channelized through much of its length, including parts of the study area. Between September 2004 and August 2005, channel rectification at three sites (M2, M3, and M5) included widening and removal of instream and riparian vegetation. Channel sinuosity generally was poor and characterized by poorly and moderately defined bends; at two sites, M1 and M6, the bayou was straight.

The physical characteristics of a stream channel and riparian characteristics can influence the structure and function of the benthic macroinvertebrate and fish communities (Stauffer and others, 2000; Brasher and others, 2003; Powers and others, 2003). The dominant substrate type noted at all Mustang Bayou sites was silt, with small amounts of sand and clay. Small amounts of gravel or gravel-sized bed material (shells) were at M2, M3, and M4. One riffle was consistently observed at M2 and one also was noted at M3 in August 2005 during very low flow. Instream cover, which provides habitat for benthic macroinvertebrates and fish, consisted primarily of macrophytes, algae, and small amounts of vegetation overhanging from the banks. Data and computed metrics that describe habitat for each site and survey are in appendix 4. 
Habitat metrics computed during each survey indicate an HQI aquatic-life-use score of "limited" (8-13) during at least one survey at all sites except M2 (table 8). HQI scores were "limited" for every survey at M6. Highest HQI scores for all sites were "intermediate" (14-19). Average HQI scores for the three surveys were "limited" for sites M3-M6 and "intermediate" for M1 and M2.

Lower HQI scores might not indicate degraded physical habitat compared to the natural condition of small streams in the Western Gulf Coastal Plain ecoregion (such as Mustang Bayou) because some metrics computed as part of the HQI are not naturally characteristic of such streams. Natural attributes of these streams, including soft (sand and clay) substrate, few riffles to complete lack of riffles, relatively uniform channels, and no defined pools, result in a lower score based on the HQI. However, other metrics observed at Mustang Bayou, such as the lack of channel sinuosity, the lack of riparian vegetation, and overall degraded aesthetics, also contributed to the limited and intermediate classifications.

\section{Biological Data}

Benthic macroinvertebrate and fish data were collected from the same reaches identified for habitat evaluation. Three surveys were done to account for seasonal differences in biotic distribution.

\section{Benthic Macroinvertebrates}

Benthic macroinvertebrate data were collected in a single, 5-minute interval of sampling using a D-frame net with 600micron mesh to sample available habitats at each site. Samples were preserved in 10-percent buffered formalin solution and shipped to a contract laboratory (EcoAnalysts, Inc., Moscow, Idaho) to be identified and enumerated. At the laboratory, organisms from each site were sorted, subsampled, and identified to the species level where possible (Lester, 2004). A reference collection, with at least one individual of each taxon identified, was provided to the USGS by EcoAnalysts, Inc. A tolerance value and functional feeding-group designation were assigned to each benthic macroinvertebrate taxon as defined by TCEQ classification guidance (Texas Natural Resource Conservation Commission, 1999b). Each macroinvertebrate community was assessed on the basis of metrics described in Texas Commission on Environmental Quality (2006).

As part of the initial biological survey (September 2004), the benthic macroinvertebrate sample from one site was split to create a primary sample and replicate samples. This was done by dividing the sample into subsections and identifying and enumerating all individuals in each subsection until a minimum of 100 individuals was obtained (Texas Natural Resource Conservation Commission, 1999b). The samples were compared to evaluate the efficiency of sample separation. The numbers of taxa in the samples differed by an average of
26 percent and indicate that a potential bias in the data can occur during sample processing.

The composition of an invertebrate community, the relative abundance of tolerant versus intolerant individuals, and the distribution of trophic (feeding) groups reflect the aquatic health of the water (Thomas and others, 2002; Skrobialowski and others, 2004). In Mustang Bayou, characteristic habitat for benthic macroinvertebrate communities include low water velocities, elevated water temperatures, mud and clay substrate, dense algal and macrophyte growth, little to no canopy, and periods of very low (less than $2.0 \mathrm{mg} / \mathrm{L}$ ) dissolved oxygen.

A total of 2,557 macroinvertebrate individuals from Mustang Bayou were identified (appendix 5) consisting of 1,509 individuals that belong to benthic, non-insect invertebrate taxa and 1,048 individuals that belong to insect taxa. The largest number of taxa (38) was collected at M3 in September 2004. The least number of taxa (12) was collected at M1 in September 2004. Overall, the Dipteran family Chironomidae was the most abundant (500 individuals), followed by gastropods (primarily Hydrobiidae, 362 individuals), segmented worms (Oligochaeta, 316 individuals), amphipods (primarily Hyalella azteca, 224 individuals), and mayflies (Ephemeroptera) (primarily Caenis sp., 232 individuals) (appendix 5).

Non-insect taxa were more numerous than insect taxa at all sites except M2 and M3 (fig. 9; appendix 5). About 89 percent of the individuals (445 of 502) at M6 were noninsect taxa, primarily Limnodrilus hoffmeisteri (Oligochaeta), Hydrobiidae (Gastropoda), and Nematoda. The most abundant non-insect taxa at each of the remaining sites were Hyalella sp. (Amphipoda) at M1 and at M4; Hydrobiidae (Gastropoda) at M2 and at M3; and Ostracoda at M5. The smallest number of non-insect taxa identified was from M3.

The number of insect individuals collected during all surveys ranged from 57 at M6 to 292 at M3 (appendix 5). The most frequently collected aquatic insect was the mayfly, Caenis sp. (Ephemoptera), which accounted for about 22 percent of all identified insects and was the most abundant insect species at M1, M2, M4, and M5 from the combined surveys. The most abundant insect species at M3 was the Polypedilum illinoense gr. (Diptera-Chironomidae). At M6, the most abundant insect was a dragonfly of the family Coenagrionidae (Odonata); although the family DipteraChironomidae comprised more species than Coenagrionidae at M6, there were fewer individuals per species (fig. 9).

Ephemeroptera, Plecoptera, and Tricoptera (EPT) taxa presence and abundance provide a measure of environmental quality (Moring 2003). The number of EPT taxa (richness) from individual surveys in Mustang Bayou ranged from 0 at M6 to 6 at M2 (appendix 6). Ephemeroptera taxa were relatively abundant at all sites except M6. No Plecoptera were collected from any of the sites. At least one specimen of Tricoptera taxa was found at each site. The most numerous Tricoptera taxon was Hydroptila sp.; 12 individuals were collected during all surveys from M2 (appendix 5). 
(A) BENTHIC (NON-INSECT) INVERTEBRATE TAXA

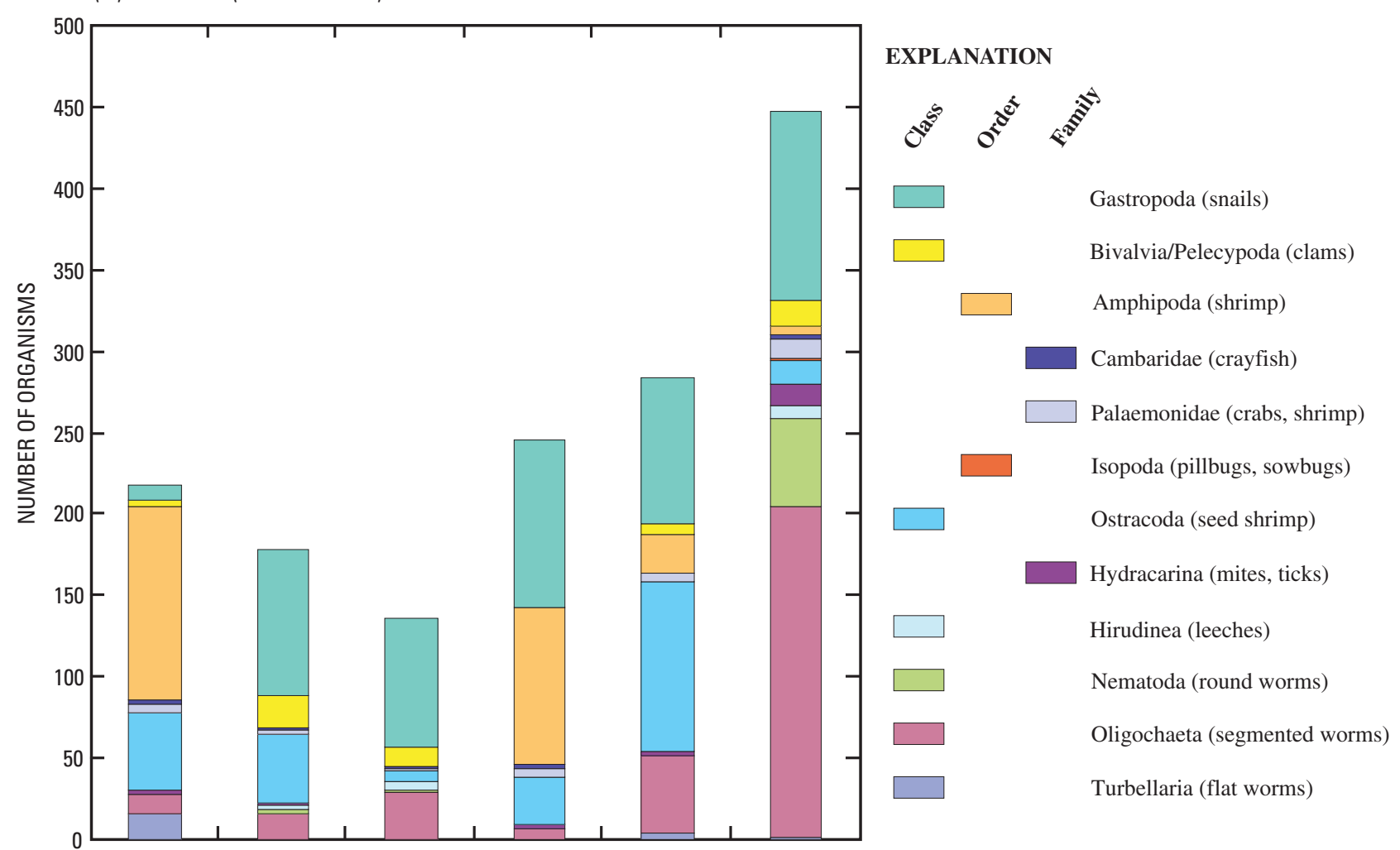

(B) INSECT TAXA

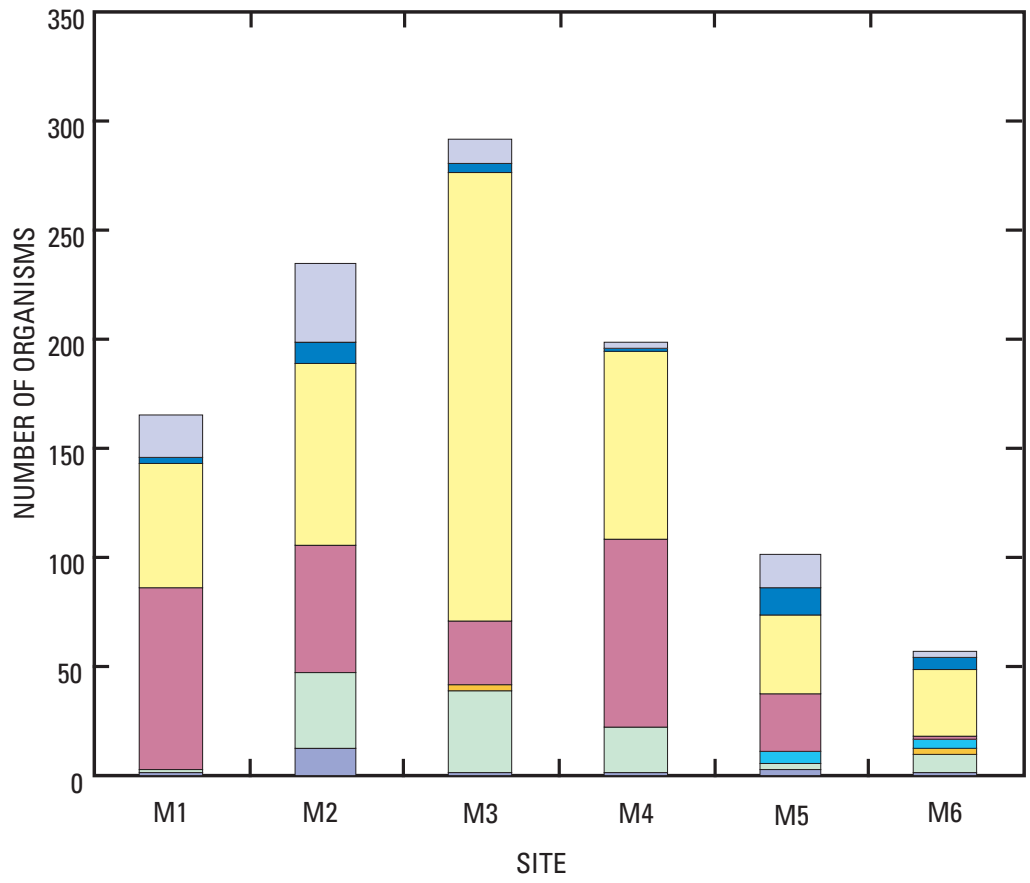

EXPLANATION

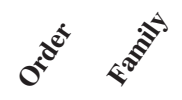

$\square \quad$ Coleoptera (beetles)

D Diptera (flies)

Diptera-Chironomidae (midges)

Ephemeroptera (mayflies)

Hemiptera (aphids, cicadas, true bugs)

Lepidoptera (butterflies, moths)

Odonata (dragonflies)

Tricoptera (caddisflies)

Figure 9. Number of specimens of (A) benthic (non-insect) invertebrate taxa, and (B) insect taxa collected from representative reach at each of six sites in Mustang Bayou near Houston, Texas, September 2004-August 2005. 
Table 8. Habitat quality index ${ }^{1}$ aquatic-life-use scoring for representative reach at each of six sites in Mustang Bayou near Houston, Texas, September 2004-August 2005.

[I, intermediate aquatic life use (14-19); L, limited aquatic life use (8-13)]

\begin{tabular}{|c|c|c|c|c|c|c|c|c|c|}
\hline \multirow{3}{*}{ Metric } & \multicolumn{9}{|c|}{ Site and survey } \\
\hline & \multicolumn{3}{|c|}{ M1 } & \multicolumn{3}{|c|}{ M2 } & \multicolumn{3}{|c|}{ M3 } \\
\hline & $\begin{array}{l}\text { Sept. } \\
2004\end{array}$ & $\begin{array}{l}\text { Apr. } \\
2005\end{array}$ & $\begin{array}{l}\text { Aug. } \\
2005\end{array}$ & $\begin{array}{l}\text { Sept. } \\
2004\end{array}$ & $\begin{array}{l}\text { Apr. } \\
2005\end{array}$ & $\begin{array}{l}\text { Aug. } \\
2005\end{array}$ & $\begin{array}{l}\text { Sept. } \\
2004\end{array}$ & $\begin{array}{l}\text { Apr. } \\
2005\end{array}$ & $\begin{array}{l}\text { Aug. } \\
2005\end{array}$ \\
\hline \multicolumn{10}{|c|}{ Primary attributes } \\
\hline \multicolumn{10}{|c|}{ Secondary attributes } \\
\hline Number of riffles & 1 & 1 & 1 & 2 & 2 & 2 & 1 & 1 & 2 \\
\hline Dimensions of largest pool & 1 & 1 & 1 & 1 & 1 & 1 & 1 & 1 & 3 \\
\hline Channel flow status & 3 & 3 & 3 & 2 & 2 & 2 & 2 & 2 & 2 \\
\hline Riparian buffer vegetation & 3 & 3 & 3 & 3 & 3 & 3 & 0 & 1 & 1 \\
\hline Aesthetics of reach & 1 & 1 & 1 & 2 & 2 & 2 & 1 & 1 & 1 \\
\hline Total score & 14 & 12 & 15 & 17 & 17 & 17 & 10 & 11 & 14 \\
\hline Habitat quality index & $\mathrm{I}$ & $\mathrm{L}$ & $\mathrm{I}$ & $\mathrm{I}$ & $\mathrm{I}$ & $\mathrm{I}$ & $\mathrm{L}$ & $\mathrm{L}$ & $\mathrm{I}$ \\
\hline
\end{tabular}

\begin{tabular}{|c|c|c|c|c|c|c|c|c|c|}
\hline \multirow{3}{*}{ Metric } & \multicolumn{9}{|c|}{ Site and survey } \\
\hline & \multicolumn{3}{|c|}{ M4 } & \multicolumn{3}{|c|}{ M5 } & \multicolumn{3}{|c|}{ M6 } \\
\hline & $\begin{array}{l}\text { Sept. } \\
2004\end{array}$ & $\begin{array}{l}\text { Apr. } \\
2005\end{array}$ & $\begin{array}{l}\text { Aug. } \\
2005\end{array}$ & $\begin{array}{l}\text { Sept. } \\
2004\end{array}$ & $\begin{array}{l}\text { Apr. } \\
2005\end{array}$ & $\begin{array}{l}\text { Aug. } \\
2005\end{array}$ & $\begin{array}{l}\text { Sept. } \\
2004\end{array}$ & $\begin{array}{l}\text { Apr. } \\
2005\end{array}$ & $\begin{array}{l}\text { Aug. } \\
2005\end{array}$ \\
\hline \multicolumn{10}{|c|}{ Primary attributes } \\
\hline Available instream cover & 3 & 1 & 2 & 3 & 2 & 2 & 1 & 1 & 2 \\
\hline \multicolumn{10}{|c|}{ Secondary attributes } \\
\hline Number of riffles & 1 & 1 & 1 & 1 & 1 & 1 & 1 & 1 & 1 \\
\hline Dimensions of largest pool & 1 & 1 & 1 & 1 & 1 & 1 & 1 & 1 & 1 \\
\hline Channel flow status & 3 & 3 & 3 & 3 & 2 & 2 & 3 & 3 & 2 \\
\hline Riparian buffer vegetation & 2 & 1 & 1 & 2 & 0 & 1 & 0 & 0 & 0 \\
\hline Aesthetics of reach & 1 & 0 & 0 & 1 & 0 & 0 & 1 & 1 & 1 \\
\hline Total score & 15 & 11 & 12 & 17 & 9 & 11 & 11 & 11 & 11 \\
\hline Habitat quality index & I & $\mathrm{L}$ & $\mathrm{L}$ & I & $\mathrm{L}$ & $\mathrm{L}$ & $\mathrm{L}$ & $\mathrm{L}$ & $\mathrm{L}$ \\
\hline
\end{tabular}

\footnotetext{
${ }^{1}$ Texas Commission on Environmental Quality (2003a, p. 40).
} 


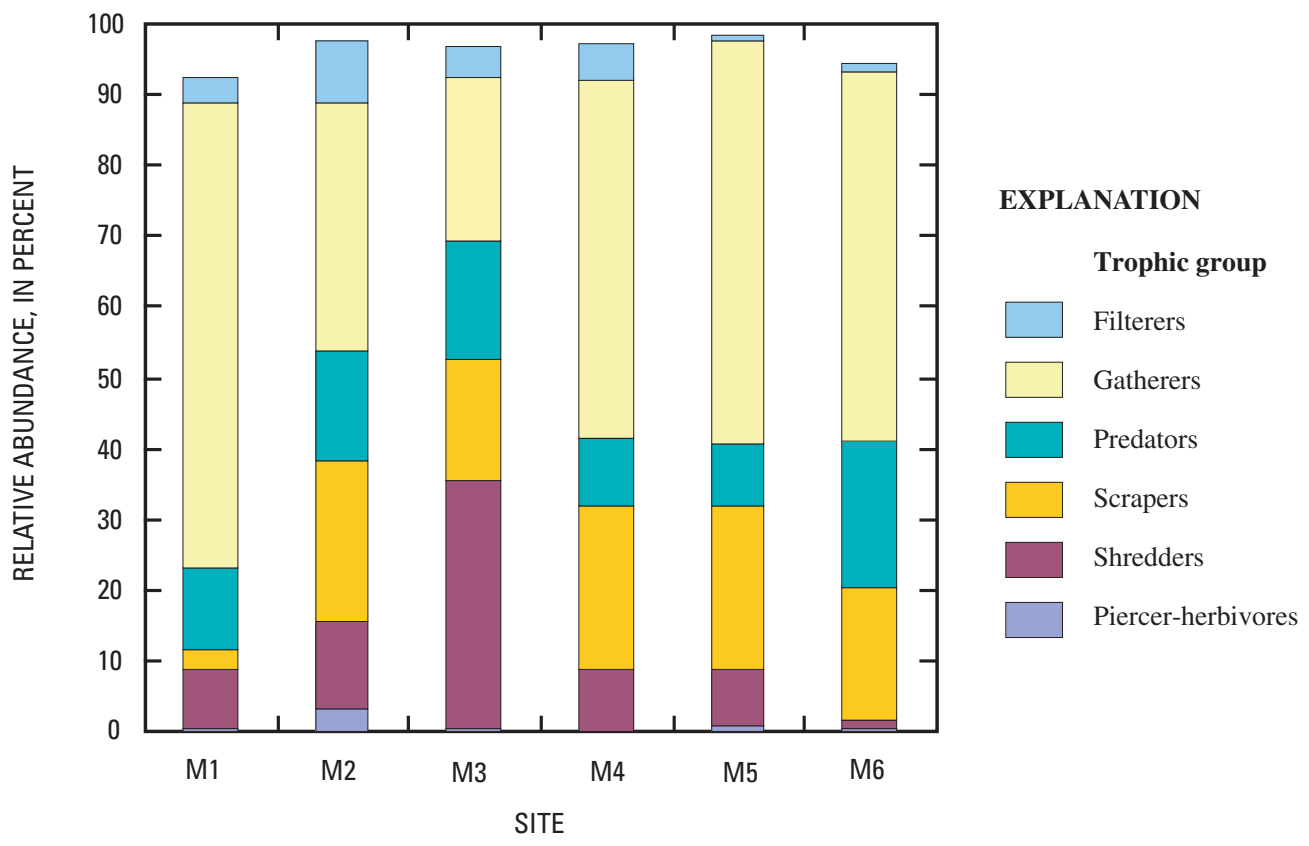

Figure 10. Relative abundance of benthic macroinvertebrate trophic groups from representative reach at each of six sites in Mustang Bayou near Houston, Texas, September 2004-August 2005.

From examination of the EPT taxa, the following observations can be made:

1. Because Plecoptera are among the most sensitive of stream insects to low dissolved oxygen levels (Stewart and Stark, 1993) and need a substrate of gravel and cobbles, the lack of Plecoptera taxa is compatible with observed dissolved oxygen and substrate conditions in Mustang Bayou.

2. The genus Caenis sp. is one of the more tolerant Ephemeroptera (Texas Natural Resource Conservation Commission, 1999b). Although other Ephemeroptera genera are present, the dominance of a tolerant species and minor occurrence of less tolerant Ephemoptera species might indicate less favorable conditions.

3. Specimens of Caenis sp. were relatively abundant in the September and August surveys at most sites (appendix 5) when unfavorable dissolved oxygen, water temperature, and flow conditions prevailed.

Invertebrates were assigned a tolerance value that is measured on a scale from 1 to 10 (Hilsenhoff, 1988); values are inversely related to stream quality (taxa/species with lower values indicate the presence of higher stream quality). Most of the macroinvertebrate community from Mustang Bayou had tolerance values that ranged from 4 to 10. From all surveys, 32 individuals were collected that had tolerance values less than 4; 16 of these were collected at M2. In contrast, 240 individuals were collected that had a tolerance value of 10; 200 of these were collected at M6.
Benthic macroinvertebrate communities were compared by computing the Hilsenhoff biotic index (HBI) (Hilsenhoff, 1988). This index is computed using the equation

$$
\mathrm{HBI}=\frac{\left[\left(\mathrm{TV}_{\mathrm{i}}\right)\left(\mathrm{n}_{\mathrm{i}}\right)\right]}{\mathrm{N}}
$$

where

$\mathrm{TV}_{\mathrm{i}}=$ tolerance value for each species;

$\mathrm{n}_{\mathrm{i}}=$ number of individuals in the species; and

$\mathrm{N}=$ total number of individuals in the collection.

HBIs ranged from 6.12 at M2 to 8.51 at M6 (appendix 6). These scores correlate to water-quality classifications of fair, where there is fairly substantial organic enrichment, to very poor, where there is severe organic enrichment (Hilsenhoff, 1988).

Vannote and others (1980) proposed that the types of macroinvertebrate communities in streams form a continuum from the headwaters to the mouth and are correlated with the sources of nutrition in the streams. Smaller streams of the headwaters would be dominated by macroinvertebrates that are capable of utilizing coarser vegetation (shredders, gatherers, scrapers). Macroinvertebrates that could utilize finer organic particulate matter (filterers, gatherers) would increase in number downstream. Gatherers were the dominant trophic (feeding) group at most sites in Mustang Bayou (fig. 10; appendix 6 ) and were about 47 percent of the overall invertebrate community; they were most similar to assemblages of gatherers of smaller streams described by Vannote and others (1980). The relative abundances of predators, scrapers, and shredders were 
similar, ranging on average from about 12 percent (shredders) to about 18 percent (scrapers). On average, filterers were not a large part of assemblages at most sites (4 percent). Overall relative abundance of trophic groups is less than 100 percent because unclassified specimens were omitted.

Benthic macroinvertebrate assemblages were scored using indexes specified by the Texas Commission on Environmental Quality (2003a). Aquatic-life-use scores (table 9) ranged from "limited" at M1 in September 2004 and April 2005 to "exceptional" at M2 in April 2005. Aquatic life use was "intermediate" at M4-M6 during all surveys, at M3 in April and August 2005, and at M1 in August 2005. Aquatic life use was "high" at M2 in September 2004 and August 2005 and at M3 in September 2004.

\section{Fish}

Fish surveys involved use of a combination of seining and electrofishing (Texas Natural Resource Conservation Commission, 1999b). After collection and identification at the stream, fish were released. Fish collected using seining were kept separate from fish collected using electrofishing for identification and enumeration so that the effectiveness of each method could be assessed. Unidentified fish were analyzed by Dr. Dean Hendrickson, ichthyologist, Texas Memorial Museum at the University of Texas, for final identification and storage. A tolerance rating and trophic group were assigned to each species (Linam and Kleinsasser, 1998). An index of biotic integrity (IBI) was computed for the combined catch for each site using scoring indexes developed to assess stream fish assemblages in the Western Gulf Coastal Plain (ecoregion 34) (Linam and others, 2002).

Forty-six species of fish (table 10) representing 20 families were collected from Mustang Bayou. Fish taxa and individual counts from each survey are listed in appendix 7. A total of 4,115 fish were collected. Sunfish (Centrarchidae) was the most abundant family with 1,153 individuals collected. The most common sunfish were longear sunfish (Lepomis megalotis) with 350 individuals and bluegill (Lepomis macrochirus) with 200 individuals. Several families were represented by only one individual. These include Gerridae (mojarras), Gobiidae (gobies), Ophichthidae (snake eels), and Percidae (perches/darters). Except for the family Percidae, these are marine or estuarine species and are not commonly collected from freshwater streams. The presence of these and other marine families reflect the connection of Mustang Bayou to Galveston Bay and the Gulf of Mexico. The family Percidae is represented by the dusky darter (Percina sciera), an intolerant species that is less likely to be found in streams that are physically or chemically disturbed, or both (Linam and Kleinsasser, 1998).

The relative abundance of major fish families at each site is shown in figure 11. Relative abundance is less than 100 percent at some sites because several families with low representation were omitted. Sunfishes (Centrachidae) and livebearers
(Poeciliidae) composed a large percentage at all sites except M1, where the dominant family (Clupeidae) comprised herrings and shads. Minnows, comprising red shiners (Cyprinella lutrensis) and bullhead minnows (Pimephales vigilax), were a large part of the fish collected at M5. The presence of red shiners, a tolerant species, might reflect disturbance of the habitat at M5. The majority were collected in April 2005, after the channel and stream banks at this site had been cleared of vegetation and the tree canopy removed. M6 had the least diversity; the fish community was dominated by three families.

Of 46 fish species, 16 were identified as having a specific tolerance or intolerance to pollution (Linam and Kleinsasser, 1998). Twelve of the species identified as tolerant are listed in appendix 7. These included (1) 55 individuals from three species of gar (alligator gar, Lepisosteus spatula; longnose gar, Lepisosteus osseus; spotted gar, Lepisosteus oculatus); (2) 334 individuals from three species of sunfish (bluegill, Lepomis macrochirus; green sunfish, Lepomis cyanellus; warmouth, Lepomis gulosus); (3) 120 individuals from two species of minnows and carp (red shiner, Cyprinella lutrensis; common carp, Cyprinus carpio); (4) 16 individuals of catfish (channel catfish, Ictalurus punctatus); and (5) 1,132 individuals from two species of livebearers (western mosquitofish, Gambusia affinis; sailfin molly, Poecilia latipinna).

Four species identified as intolerant to pollution (Linam and Kleinsasser, 1998) are listed in appendix 7. In addition to one dusky darter (Percina sciera), 10 brook silversides (Labidesthes sicculus), 22 tadpole madtoms (Noturus gyrinus), and 54 Atlantic croakers (Micropogonias undulatus) were collected. Intolerant species were found at all sites except M6.

The presence and relative abundance of tolerant and intolerant fish reflect stream conditions. Intolerant fish species indicate high and moderate quality sites (Linam and Kleinsasser, 1998) and become increasingly scarce with pollution or destruction of suitable habitat. Tolerant fish species have increased distribution and abundance when site conditions are less favorable and become dominant in disturbed sites (Linam and Kleinsasser, 1998). In Mustang Bayou, tolerant species are dominant (1,657 individuals) compared to intolerant species (87 individuals). However, because Mustang Bayou is in the Gulf Coastal Plain (ecoregion 34), the distribution of tolerant and intolerant species does not necessarily reflect pollution. Common, naturally occurring characteristics of coastal streams include mud and sand substrate, slow velocities, absence of riffles, little tree canopy, and variable water quality that might be limiting to intolerant species.

Fish species can be separated into trophic groups, which describe the manner in which they feed. There are three trophic (feeding) groups: (1) omnivores, generalized feeders; (2) piscivores, feed on other fish; and (3) invertivores, feed on invertebrates, mostly insects. At Mustang Bayou sites (fig. 12), the majority of fish were invertivores, ranging from 50.8 percent of the fish at M1 to 90.3 percent at M5. Piscivores were the next most abundant, ranging from 6.4 percent of the fish at M3 to 22.6 percent at M1. Omnivores ranged from 1.2 percent of the fish at M5 to 26.6 percent at M1. 


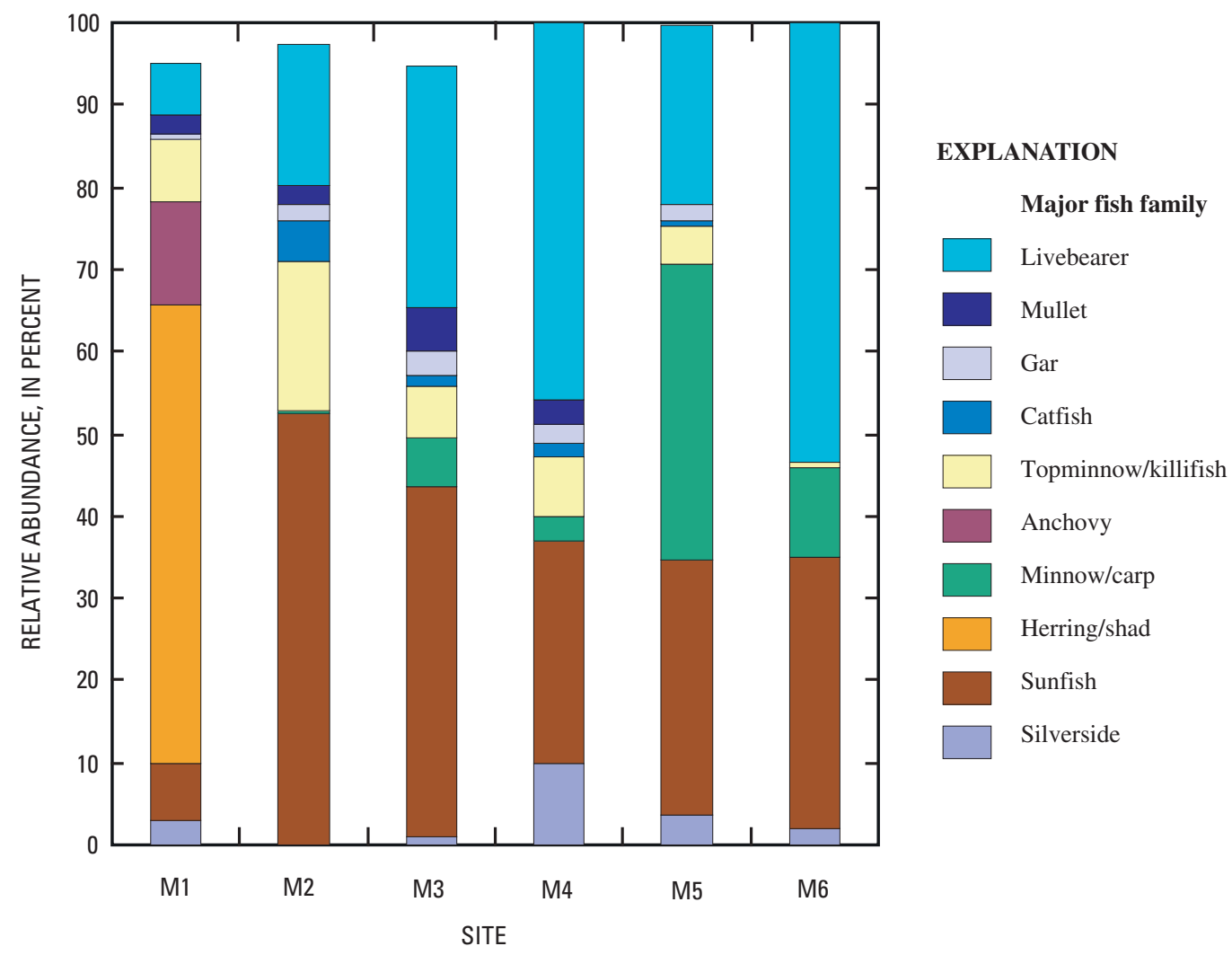

Figure 11. Relative abundance of major fish families from representative reach at each of six sites in Mustang Bayou near Houston, Texas, September 2004-August 2005.

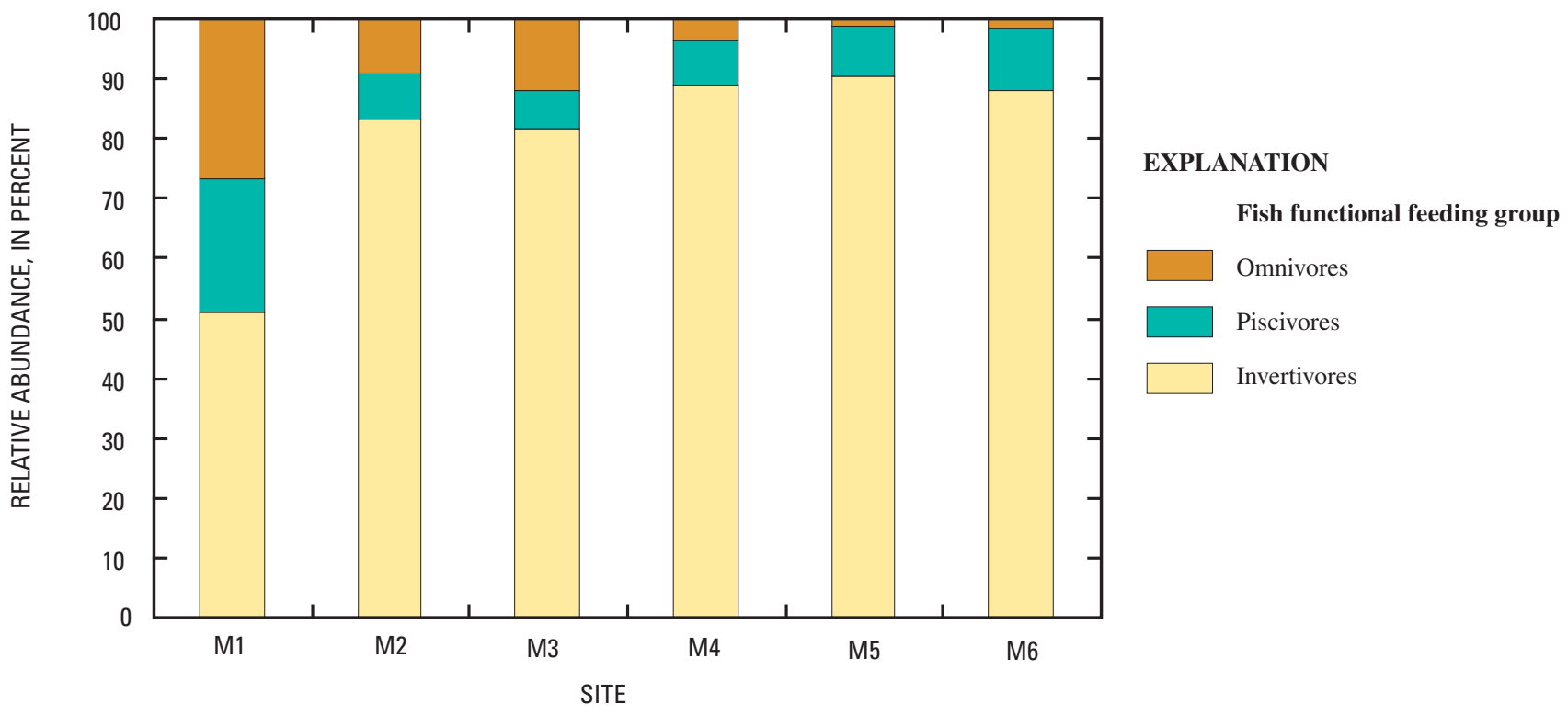

Figure 12. Relative abundance of fish functional feeding groups from representative reach at each of six sites in Mustang Bayou near Houston, Texas, September 2004-August 2005. 
Table 9. Metrics and aquatic-life-use ${ }^{1}$ scoring for benthic macroinvertebrates in representative reach at each of six sites in Mustang Bayou near Houston, Texas, September 2004-August 2005.

[EPT, Ephemeroptera, Plecoptera, Trichoptera; L, limited (less than 22); I, intermediate (22-28); H, high (29-36); E, exceptional (greater than 36)]

\begin{tabular}{|c|c|c|c|c|c|c|c|c|c|}
\hline \multirow{3}{*}{ Metric } & \multicolumn{9}{|c|}{ Site and survey } \\
\hline & \multicolumn{3}{|c|}{ M1 } & \multicolumn{3}{|c|}{ M2 } & \multicolumn{3}{|c|}{ M3 } \\
\hline & $\begin{array}{l}\text { Sept. } \\
2004\end{array}$ & $\begin{array}{l}\text { Apr. } \\
2005\end{array}$ & $\begin{array}{l}\text { Aug. } \\
2005\end{array}$ & $\begin{array}{l}\text { Sept. } \\
2004\end{array}$ & $\begin{array}{l}\text { Apr. } \\
2005\end{array}$ & $\begin{array}{l}\text { Aug. } \\
2005\end{array}$ & $\begin{array}{l}\text { Sept. } \\
2004\end{array}$ & $\begin{array}{l}\text { Apr. } \\
2005\end{array}$ & $\begin{array}{l}\text { Aug. } \\
2005\end{array}$ \\
\hline Taxa richness & 2 & 2 & 2 & 3 & 4 & 3 & 4 & 2 & 3 \\
\hline EPT taxa abundance & 1 & 1 & 1 & 2 & 2 & 2 & 2 & 1 & 1 \\
\hline Hilsenhoff biotic index (HBI) & 1 & 1 & 1 & 1 & 1 & 1 & 1 & 1 & 1 \\
\hline Percentage Chironomidae & 3 & 1 & 2 & 4 & 1 & 3 & 1 & 1 & 1 \\
\hline Percentage dominant taxon & 2 & 2 & 1 & 2 & 4 & 3 & 4 & 3 & 4 \\
\hline Percentage dominant functional feeding grout (FFG) & 1 & 1 & 1 & 3 & 4 & 3 & 3 & 1 & 4 \\
\hline Percentage predators & 3 & 4 & 4 & 1 & 4 & 2 & 4 & 4 & 2 \\
\hline Ratio of intolerant to tolerant taxa & 1 & 1 & 1 & 1 & 1 & 1 & 1 & 1 & 1 \\
\hline Percentage total Trichoptera as Hydropsychidae & 1 & 1 & 4 & 4 & 4 & 4 & 3 & 1 & 1 \\
\hline Number of non-insect taxa & 3 & 4 & 4 & 4 & 4 & 4 & 4 & 4 & 4 \\
\hline Percentage collector-gatherers & 1 & 1 & 1 & 1 & 4 & 1 & 2 & 4 & 4 \\
\hline Percentage of total number as Elmidae & 1 & 1 & 1 & 4 & 4 & 3 & 4 & 1 & 1 \\
\hline Total score & 20 & 20 & 23 & 30 & 37 & 30 & 33 & 24 & 27 \\
\hline Aquatic life use & $\mathrm{L}$ & $\mathrm{L}$ & I & $\mathrm{H}$ & E & $\mathrm{H}$ & $\mathrm{H}$ & I & I \\
\hline
\end{tabular}

\begin{tabular}{|c|c|c|c|c|c|c|c|c|c|}
\hline \multirow{3}{*}{ Metric } & \multicolumn{9}{|c|}{ Site and survey } \\
\hline & \multicolumn{3}{|c|}{ M4 } & \multicolumn{3}{|c|}{ M5 } & \multicolumn{3}{|c|}{ M6 } \\
\hline & $\begin{array}{l}\text { Sept. } \\
2004\end{array}$ & $\begin{array}{l}\text { Apr. } \\
2005\end{array}$ & $\begin{array}{l}\text { Aug. } \\
2005\end{array}$ & $\begin{array}{l}\text { Sept. } \\
2004\end{array}$ & $\begin{array}{l}\text { Apr. } \\
2005\end{array}$ & $\begin{array}{l}\text { Aug. } \\
2005\end{array}$ & $\begin{array}{l}\text { Sept. } \\
2004\end{array}$ & $\begin{array}{l}\text { Apr. } \\
2005\end{array}$ & $\begin{array}{l}\text { Aug. } \\
2005\end{array}$ \\
\hline Taxa richness & 2 & 3 & 2 & 3 & 3 & 2 & 2 & 3 & 3 \\
\hline EPT taxa abundance & 1 & 1 & 1 & 1 & 1 & 1 & 1 & 1 & 1 \\
\hline Hilsenhoff biotic index (HBI) & 1 & 1 & 1 & 1 & 1 & 1 & 1 & 1 & 1 \\
\hline Percentage Chironomidae & 2 & 1 & 3 & 4 & 1 & 4 & 3 & 4 & 2 \\
\hline Percentage dominant taxon & 3 & 4 & 3 & 1 & 4 & 1 & 1 & 3 & 2 \\
\hline Percentage dominant functional feeding grout (FFG) & 1 & 3 & 3 & 2 & 2 & 1 & 2 & 1 & 2 \\
\hline Percentage predators & 4 & 1 & 3 & 1 & 3 & 4 & 4 & 1 & 4 \\
\hline Ratio of intolerant to tolerant taxa & 1 & 1 & 1 & 1 & 1 & 1 & 1 & 1 & 1 \\
\hline Percentage total Trichoptera as Hydropsychidae & 1 & 1 & 4 & 1 & 4 & 1 & 4 & 1 & 1 \\
\hline Number of non-insect taxa & 4 & 4 & 3 & 4 & 4 & 4 & 4 & 4 & 4 \\
\hline Percentage collector-gatherers & 1 & 1 & 1 & 2 & 1 & 1 & 1 & 1 & 1 \\
\hline Percentage of total number as Elmidae & 1 & 1 & 1 & 4 & 1 & 1 & 1 & 1 & 1 \\
\hline Total score & 22 & 22 & 26 & 25 & 26 & 22 & 25 & 22 & 23 \\
\hline Aquatic life use & I & I & I & I & I & I & I & I & I \\
\hline
\end{tabular}

${ }^{1}$ Texas Commission on Environmental Quality (2003a, p. 39). 
Table 10. Fish species collected from representative reach at each of six sites in Mustang Bayou near Houston, Texas, September 2004-August 2005.

[F, freshwater; E, estuarine; M, marine; Fa, anadromous (spawn in freshwater, but mature in marine)]

\begin{tabular}{|c|c|c|c|c|c|c|}
\hline & \multicolumn{6}{|c|}{ Site } \\
\hline & M1 & M2 & M3 & M4 & M5 & M6 \\
\hline \multicolumn{7}{|l|}{ Freshwater fish species } \\
\hline \multicolumn{7}{|l|}{ Alligator gar (F) } \\
\hline \multicolumn{7}{|l|}{ Banded pygmy sunfish (F) } \\
\hline \multicolumn{7}{|l|}{ Blackstripe topminnow $(\mathbf{F})$} \\
\hline \multicolumn{7}{|l|}{ Blue catfish $(\mathbf{F})$} \\
\hline \multicolumn{7}{|l|}{ Bluegill (F) } \\
\hline \multicolumn{7}{|l|}{ Brook silverside (F) } \\
\hline Bullhead minnow (F) & & & & & & \\
\hline \multicolumn{7}{|l|}{ Channel catfish $(\mathbf{F})$} \\
\hline \multicolumn{7}{|l|}{ Common carp (F) } \\
\hline \multicolumn{7}{|l|}{ Dusky darter (F) } \\
\hline \multicolumn{7}{|l|}{ Flathead catfish $(\mathbf{F})$} \\
\hline \multirow{2}{*}{\multicolumn{7}{|c|}{$\begin{array}{l}\text { Golden topminnow }(\mathbf{F}) \\
\text { Green sunfish }(\mathbf{F})\end{array}$}} \\
\hline & & & & & & \\
\hline \multicolumn{7}{|l|}{ Hogchoker (F) } \\
\hline \multicolumn{7}{|l|}{ Largemouth bass $(\mathbf{F})$} \\
\hline \multicolumn{7}{|l|}{ Longear sunfish $(\mathbf{F})$} \\
\hline \multicolumn{7}{|l|}{ Longnose gar $(\mathbf{F})$} \\
\hline \multicolumn{7}{|l|}{ Orangespotted sunfish (F) } \\
\hline \multicolumn{7}{|l|}{ Pugnose minnow (F) } \\
\hline \multirow{2}{*}{\multicolumn{7}{|c|}{$\begin{array}{l}\text { Red shiner }(\mathbf{F}) \\
\text { Redear sunfish }(\mathbf{F})\end{array}$}} \\
\hline & & & & & & \\
\hline \multicolumn{7}{|l|}{ Sailfin molly (F) } \\
\hline Sheepshead minnow $(\mathbf{F} / \mathbf{E} / \mathbf{M})^{1}$ & & & & & & \\
\hline Skipjack herring (F) & & & & & & \\
\hline Spotted gar $(\mathbf{F})$ & & & & & & \\
\hline Spotted sunfish $(\mathbf{F})$ & & & & & & \\
\hline Tadpole madtom $(\mathbf{F})$ & & & & & & \\
\hline Warmouth (F) & & & & & & \\
\hline Western mosquitofish $(\mathbf{F})$ & & & & & & \\
\hline Yellow bullhead $(\mathbf{F})$ & & & & & & \\
\hline Estuarine/marine fish species & & & & & & \\
\hline Amazon molly (E/F) & & & & & & \\
\hline American shad (M/Fa) & & & & & & \\
\hline Atlantic croaker (M/E) & & & & & & \\
\hline Atlantic needlefish $(\mathbf{M} / \mathbf{E} / \mathbf{F})$ & & & & & & \\
\hline Bay anchovy (M/E) & & & & & & \\
\hline Chain pipefish (M/E) & & & & & & \\
\hline Clown goby (M/E) & & & & & & \\
\hline Flat anchovy (M) & & & & & & \\
\hline Gulf killifish (M/E) & & & & & & \\
\hline Gulf menhaden (M/E) & & & & & & \\
\hline Inland silverside (E/F) & & & & & & \\
\hline Mojarra (M/E) & & & & & & \\
\hline Rainwater killifish (E) & & & & & & \\
\hline Saltmarsh topminnow (M/E) & & & & & & \\
\hline Speckled worm eel (M/E) & & & & & & \\
\hline Striped mullet $(\mathbf{M} / \mathbf{E} / \mathbf{F})$ & & & & & & \\
\hline
\end{tabular}




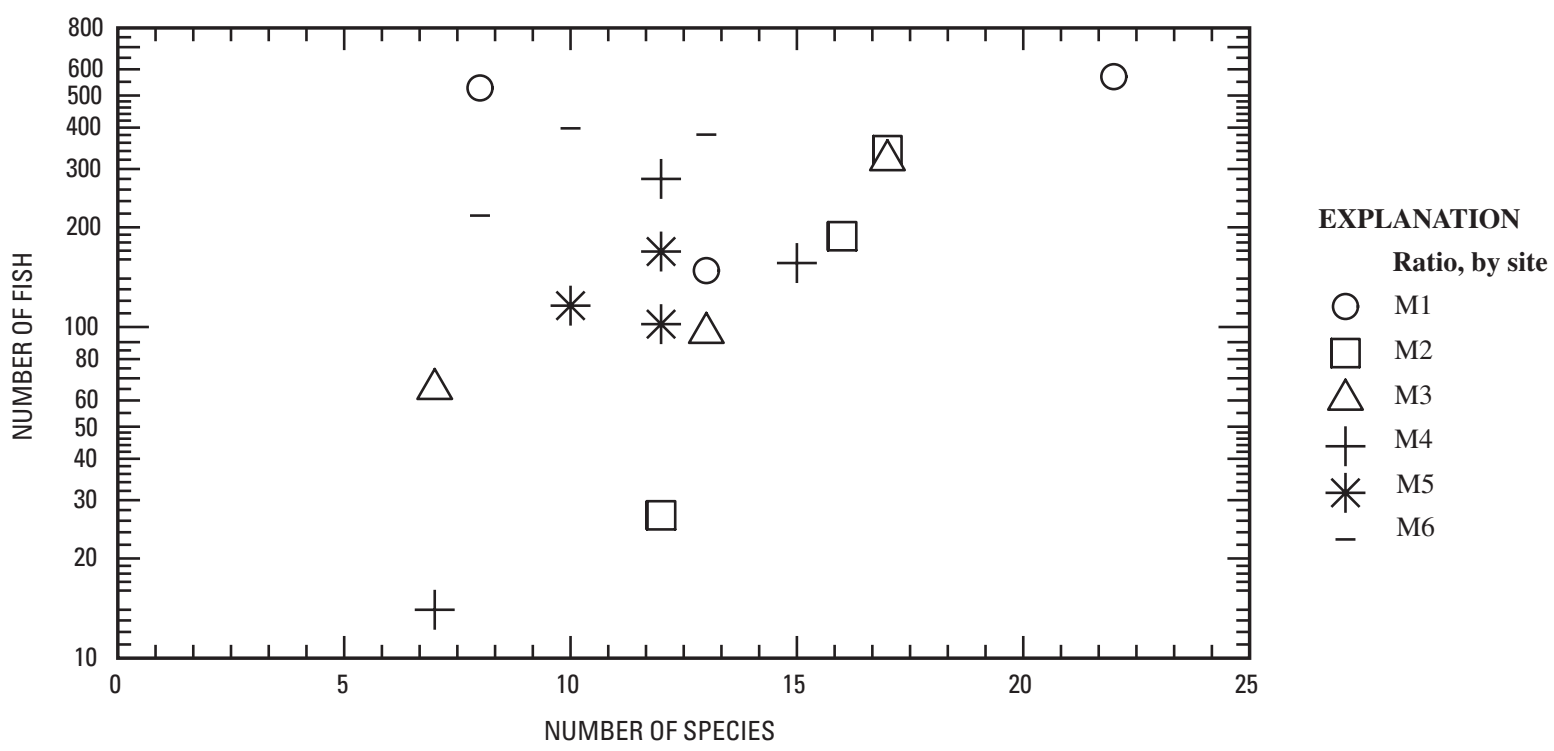

Figure 13 Number of fish collected relative to number of fish species from representative reach at each of six sites in Mustang Bayou near Houston, Texas, September 2004-August 2005.

Trophic composition metrics might help to evaluate the quality of the stream habitat and chemical quality in that more generalized feeders (that is, omnivores) become a larger percentage of the population with degradation of conditions (Linam and Kleinsasser, 1998).

The distribution of the total number of fish collected relative to the number of species from each site and survey are shown in figure 13. If the number of species is proportional to the number of individuals collected (high sampling efficiency), a graph of data for the sites would have a linear relation. Departures from a linear relation between the number of fish and species in Mustang Bayou can reflect several factors, including sampling efficiency (bias), seasonality, and local site conditions. For example, a similar number of fish were collected at M1 in both September 2004 (527 fish) and April 2005 (570 fish); however the number of species differed greatly (eight and 22 species, respectively). In the September survey, two marine species, gulf menhaden (Brevoortia patronus) and bay anchovy (Anchoviella mitchilli), were 500 of 527 fish (appendix 7). In April, freshwater skipjack herring (Alosa chrysochloris) were 317 of 570 fish. Because of the complexity of possible factors, it was not possible to differentiate the reasons for variability in fish distribution or if sampling bias existed.

Sorensen's index of similarity (Oklahoma Water Resources Board, 2001) is one index used to compare sites and gain an understanding of the fish data. It is computed using the equation

$$
S=\frac{2 c}{a+b},
$$

where

$$
\begin{aligned}
& \mathrm{a}=\text { number of taxa in community } \mathrm{a} ; \\
& \mathrm{b}=\text { number of taxa in community } \mathrm{b} ; \text { and } \\
& \mathrm{c}=\text { number of taxa common to both. }
\end{aligned}
$$

To compute this index, the number of fish species assessed at each site was compared with the number of species at the adjacent upstream site (appendix 8). Computed coefficients can range from near 0 , when two assemblages are completely dissimilar, to 1 , when they are identical. For example, in September 2004, M1 had eight species; M2 had 12 species (appendix 7). Five species were common to both sites. An index of 0.50 is computed by dividing twice the number of common species (2 times 5) by the sum of the numbers of species at both sites ( 8 plus 12). Both minimum and maximum Sorensen coefficients occurred when comparing M2 and M3 and ranged from 0.47 in August 2005 to 0.76 in April 2005. Coefficients for M1 and M2 had the lowest mean index of similarity (0.52). M3-M4 and M5-M6 were most similar, each having a mean coefficient of 0.68 . The mean coefficient for all sites was 0.62 .

To minimize potential bias in the number of fish species caused by differences in abundance, Menhinick's species diversity index (D) (Menhinick, 1964) was computed using the equation

$$
\mathrm{D}=\frac{\mathrm{s}}{\sqrt{\mathrm{N}}},
$$

where

$\mathrm{s}=$ number of species in population sampled; and $\mathrm{N}$ = number of individuals in population. 
Table 11. Index of biotic integrity' aquatic-life-use scoring for ecoregion 34 for fish in representative reach at each of six sites in Mustang Bayou near Houston, Texas, September 2004-August 2005.

[I, intermediate aquatic life use (31-38); H, high aquatic life use (39-48); L, limited aquatic life use (less than 31); E, exceptional aquatic life use (equal to or greater than 49)]

\begin{tabular}{|c|c|c|c|c|c|c|c|c|c|}
\hline \multirow{3}{*}{ Metric } & \multicolumn{9}{|c|}{ Site and survey } \\
\hline & \multicolumn{3}{|c|}{ M1 } & \multicolumn{3}{|c|}{ M2 } & \multicolumn{3}{|c|}{ M3 } \\
\hline & $\begin{array}{l}\text { Sept. } \\
2004\end{array}$ & $\begin{array}{l}\text { Apr. } \\
2005\end{array}$ & $\begin{array}{l}\text { Aug. } \\
2005\end{array}$ & $\begin{array}{l}\text { Sept. } \\
2004\end{array}$ & $\begin{array}{l}\text { Apr. } \\
2005\end{array}$ & $\begin{array}{l}\text { Aug. } \\
2005\end{array}$ & $\begin{array}{l}\text { Sept. } \\
2004\end{array}$ & $\begin{array}{l}\text { Apr. } \\
2005\end{array}$ & $\begin{array}{l}\text { Aug. } \\
2005\end{array}$ \\
\hline Total number of fish species & 3 & 5 & 5 & 5 & 5 & 5 & 3 & 5 & 5 \\
\hline Number of native cyprinid species & 1 & 1 & 1 & 1 & 1 & 1 & 1 & 3 & 3 \\
\hline Number of intolerant species & 5 & 5 & 1 & 1 & 5 & 5 & 1 & 5 & 5 \\
\hline $\begin{array}{l}\text { Percent individuals as tolerant species } \\
\text { (excluding western mosquitofish) }\end{array}$ & 1 & 5 & 1 & 1 & 1 & 1 & 1 & 1 & 1 \\
\hline Percent individuals as omnivores & 1 & 5 & 5 & 3 & 3 & 5 & 1 & 5 & 5 \\
\hline Percent individuals as invertivores & 1 & 3 & 5 & 5 & 5 & 5 & 5 & 5 & 5 \\
\hline Percent individuals as nonnative species & 5 & 5 & 5 & 5 & 5 & 5 & 5 & 5 & 5 \\
\hline Percent of individuals with disease or other anomaly & 5 & 5 & 5 & 5 & 5 & 5 & 1 & 5 & 5 \\
\hline Total score & 36 & 48 & 43 & 38 & 46 & 48 & 30 & 46 & 50 \\
\hline Index of biotic integrity & I & $\mathrm{H}$ & $\mathrm{H}$ & I & $\mathrm{H}$ & $\mathrm{H}$ & $\mathrm{L}$ & $\mathrm{H}$ & E \\
\hline
\end{tabular}

\begin{tabular}{|c|c|c|c|c|c|c|c|c|c|}
\hline \multirow{3}{*}{ Metric } & \multicolumn{9}{|c|}{ Site and survey } \\
\hline & \multicolumn{3}{|c|}{ M4 } & \multicolumn{3}{|c|}{ M5 } & \multicolumn{3}{|c|}{ M6 } \\
\hline & $\begin{array}{l}\text { Sept. } \\
2004\end{array}$ & $\begin{array}{l}\text { Apr. } \\
2005\end{array}$ & $\begin{array}{l}\text { Aug. } \\
2005\end{array}$ & $\begin{array}{l}\text { Sept. } \\
2004\end{array}$ & $\begin{array}{l}\text { Apr. } \\
2005\end{array}$ & $\begin{array}{l}\text { Aug. } \\
2005\end{array}$ & $\begin{array}{l}\text { Sept. } \\
2004\end{array}$ & $\begin{array}{l}\text { Apr. } \\
2005\end{array}$ & $\begin{array}{l}\text { Aug. } \\
2005\end{array}$ \\
\hline Total number of fish species & 3 & 5 & 5 & 5 & 5 & 5 & 3 & 5 & 5 \\
\hline Number of native cyprinid species & 1 & 3 & 1 & 3 & 3 & 1 & 3 & 3 & 3 \\
\hline Number of intolerant species & 5 & 5 & 5 & 1 & 5 & 1 & 1 & 1 & 1 \\
\hline $\begin{array}{l}\text { Percent individuals as tolerant species } \\
\text { (excluding western mosquitofish) }\end{array}$ & 1 & 1 & 1 & 1 & 1 & 1 & 1 & 1 & 1 \\
\hline Percent individuals as omnivores & 5 & 3 & 5 & 5 & 5 & 5 & 5 & 5 & 5 \\
\hline Percent individuals as invertivores & 5 & 5 & 5 & 5 & 5 & 5 & 5 & 5 & 5 \\
\hline Percent individuals as nonnative species & 5 & 5 & 5 & 5 & 5 & 5 & 5 & 5 & 5 \\
\hline Percent of individuals with disease or other anomaly & 5 & 5 & 5 & 3 & 5 & 5 & 5 & 5 & 5 \\
\hline Total score & 42 & 46 & 48 & 40 & 46 & 41 & 44 & 42 & 46 \\
\hline Index of biotic integrity & $\mathrm{H}$ & $\mathrm{H}$ & $\mathrm{H}$ & $\mathrm{H}$ & $\mathrm{H}$ & $\mathrm{H}$ & $\mathrm{H}$ & $\mathrm{H}$ & $\mathrm{H}$ \\
\hline
\end{tabular}

${ }^{1}$ Linam and others (2002). 
Table 12. Average aquatic-life-use scores for stream habitat, benthic macroinvertebrates, and fish in representative reach at each of six sites in Mustang Bayou near Houston, Texas, September 2004-August 2005.

[I, intermediate; L, limited; H, high]

\begin{tabular}{lcccccc}
\hline \multirow{2}{*}{ Category } & \multicolumn{7}{c}{ Site } \\
\cline { 2 - 7 } & M1 & M2 & M3 & M4 & M5 & M6 \\
\hline Habitat $^{1}$ & I & I & L & L & L & L \\
Benthic macroinvertebrates $^{2}$ & L & H & I & I & I & I \\
Fish $^{3}$ & H & H & H & H & H & H \\
\hline
\end{tabular}

\footnotetext{
${ }^{1}$ Habitat quality index aquatic-life-use scores (Texas Commission on Environmental Quality, 2003a, p. 40)

${ }^{2}$ Aquatic-life-use scores for benthic macroinvertibrates (Texas Commission on Environmental Quality, 2003a, p. 39).

${ }^{3}$ Index of biotic integrity aquatic-life-use scores for ecoregion 34 (Linam and others, 2002).
}

The index is directly proportional to diversity within the fish assemblage. At Mustang Bayou, Menhinick's index ranged from 0.35 at M1 in September 2004 to a maximum of 2.31 at M2, also in September 2004. Average index values were smallest at M6 (0.57) and largest at M2 (1.54). Except for M1 and M6, coefficients were comparable to those computed for other watersheds near Houston and Beaumont, Tex. which were evaluated during previous studies. Average Menhinick's coefficients were 1.15 for Lake Creek, 1.74 for Peach Creek, and 1.46 for Caney Creek (East and SneckFahrer, 2004), all tributaries to Lake Houston, north of Houston. Coefficients for the Neches River watershed north of Beaumont ranged from a minimum of about 1.15 to about 1.60 (Moring, 2003, p. 4, fig. 11).

Fish assemblages from each survey were scored (table 11) on the basis of selected metrics. Because fish assemblages naturally differ in streams throughout Texas in response to climate, geography, and other factors, a single set of indexes could not adequately compare assemblages and rank aquatic life use in those streams. Fish from sites in Mustang Bayou were scored using the regional IBI proposed for ecoregion 34 (Linam and others, 2002). Fish communities supported a "high" aquatic life use for all surveys at sites M4-M6. Individual scores at M1 and M2 ranged from "intermediate" to "high" aquatic life use. Scores ranged from "limited" to "exceptional" aquatic life use at M3.

Average scores of aquatic life use from the three habitat, macroinvertebrate, and fish surveys completed between September 2004 and August 2005 are presented in table 12. Average HQI classifications range from "limited" (M3-M6) to "intermediate" (M1-M2) aquatic life use. Classifications obtained from macroinvertebrate surveys range from "limited" at M1 to "high" at M2. Classifications at M3-M6 are "intermediate." Average IBI aquatic-life-use scores for fish assessments are "high" at all sites.

\section{Summary}

The Mustang Bayou watershed is primarily in Brazoria County southeast of Houston, Tex. Although no State 303(d) or 305(b) water-quality standards have been adopted by the Texas Commission on Environmental Quality (TCEQ) for Mustang Bayou, urban development is occurring in the watershed, increasing the possibility of changes in the water quality, physical stream habitat, and aquatic biota. Previous assessments of Mustang Bayou have been of a localized nature and narrow focus; therefore, these studies did not facilitate adoption of water-quality standards or classification of the aquatic life use of the bayou.

This report, prepared in cooperation with the HoustonGalveston Area Council and the TCEQ, presents water-quality, stream-habitat, and biological data collected during September 2004-August 2005 and bed sediment data collected in September 2005.

Water-quality, stream-habitat, benthic-macroinvertebrate, and fish data were collected at six sites (downstream order M6-M1) along Mustang Bayou. Water-quality data consisted of continuously monitored (for periods of 24 hours to several days, six times) water temperature, $\mathrm{pH}$, specific conductance, and dissolved oxygen and periodically collected samples of selected properties and constituents. Concentrations of nutrients, biochemical oxygen demand, chlorophyll- $a$, E. coli, chloride, sulfate, dissolved and suspended solids, suspended sediment concentration, and pesticides were assessed eight times at all sites. Selected water-quality constituents were compared to State screening levels to evaluate potential water-quality concerns. Stream habitat and aquatic biota (benthic macroinvertebrates and fish) were assessed at each site three times during the study. Aquatic-life-use classifications were obtained from these assessments. 
Dissolved oxygen is a primary component used to evaluate the suitability of a stream to sustain life and is a component of stream classification. The assumed aquatic-lifeuse classification of Mustang Bayou is "high," which means that dissolved oxygen must not fall below criteria based on streamflow characteristics (perennial or intermittent) and on salinity. Mean dissolved oxygen concentrations were below the 24-hour average standard in at least one monitoring period at all sites except M2. Minimum dissolved oxygen concentrations were below the minimum standards 40 to 67 percent of the time at all sites except M2.

No concentrations of nitrogen compounds and phosphorus exceeded State screening levels. The largest ammonia plus organic nitrogen concentration was $2.8 \mathrm{mg} / \mathrm{L}$; the organic nitrogen contribution was computed to be between about 85 to 95 percent of the concentration of ammonia plus organic nitrogen measured at all sites. Nitrite plus nitrate nitrogen concentrations ranged from less than or the reporting level $(0.016 \mathrm{mg} / \mathrm{L})$ at all sites to a maximum concentration of 0.67 $\mathrm{mg} / \mathrm{L}$ at M1. Orthophosphate phosphorus concentrations were largest at M1 with a maximum concentration of $0.341 \mathrm{mg} / \mathrm{L}$. The contribution of orthophosphate to the total phosphorus concentration ranged from about 4 percent at M6 to 72 percent at M1. The median total phosphorus concentration from all sites was $0.11 \mathrm{mg} / \mathrm{L}$.

Biochemical oxygen demand, the measure of oxygen consumption by microorganisms during decomposition, was less than $4.0 \mathrm{mg} / \mathrm{L}$ at all sites except M6, where the maximum concentration was $8.1 \mathrm{mg} / \mathrm{L}$. Concentrations of chlorophyll$a$ were less than the screening level $(11.6 \mu \mathrm{g} / \mathrm{L})$ at all sites except M6, where four of eight samples exceeded $11.6 \mu \mathrm{g} / \mathrm{L}$. In 20 of 48 samples from Mustang Bayou, E. coli densities were greater than 394 cols./100 mL, the State single-sample water-quality standard. The median density from all samples was 220 cols./100 mL.

There are no aquatic-life-use criteria for chloride, sulfate, suspended solids, and dissolved solids; however they provide additional information on the quality of water for general uses or aesthetic appeal. Median chloride concentrations from each site were between 42.2 and $123 \mathrm{mg} / \mathrm{L}$. The median sulfate concentration from Mustang Bayou was $19.8 \mathrm{mg} / \mathrm{L}$. The median concentration of suspended solids from all samples was 16.0 $\mathrm{mg} / \mathrm{L}$. The largest dissolved solids concentration was 1,050 $\mathrm{mg} / \mathrm{L}$ measured at M4; the median concentration of dissolved solids from all samples was $346 \mathrm{mg} / \mathrm{L}$.

Fifteen pesticide compounds (six herbicides and nine insecticides) were detected in 24 water samples. The most frequently detected pesticide was atrazine, which was measured in every sample. Concentrations ranged from 0.010 to $1.42 \mu \mathrm{g} / \mathrm{L}$. Other frequently detected pesticides were CIAT, prometon, tebuthiuron, fipronil, fipronil sulfide, and fipronil sulfone.

Sediment samples were collected from the stream bottom at M1 and analyzed for concentrations of organochlorine pesticides, polycyclic aromatic hydrocarbons (PAHs), trace elements (metals), and polychlorinated biphenyls
(PCBs). No organochlorine pesticides or PCBs were detected. No concentrations of metals exceeded State screening levels. Concentrations of $11 \mathrm{PAH}$ compounds were detected at measurable concentrations, and three other PAH compounds were detected but not quantified by the laboratory. All concentrations were less than respective sediment-quality screening levels.

Characteristics of habitat measured during each survey were scored using a habitat quality index (HQI). The HQI indicated an aquatic-life-use score of "limited" (8-13) during at least one survey at all sites except M2 and were "limited" for every survey at M6. Highest HQI scores were "intermediate" (14-19). Average scores were "limited" for M3-M6 and "intermediate" for M1 and M2.

A total of 2,557 macroinvertebrate individuals were identified from Mustang Bayou consisting of 1,509 individuals that belong to benthic, non-insect invertebrate taxa and 1,048 individuals that belong to insect taxa. Overall, the Dipteran family Chironomidae was the most abundant, followed by gastropods, segmented worms, amphipods, and mayflies (Ephemeroptera). Benthic macroinvertebrate assemblages were scored using indexes specified by the Texas Commission on Environmental Quality. Aquatic-life-use scores ranged from "limited" at M1 in September 2004 and April 2005 to "exceptional" at M2 in April 2005. Average scores were "limited" at M1, "intermediate" at M3-M6, and "high" at $\mathrm{M} 2$.

Forty-six species of fish representing 20 families were collected from Mustang Bayou. A total of 4,115 fish were collected. Sunfish (Centrarchidae) was the most abundant family with 1,153 individuals collected. Of 46 fish species, 16 were identified as having a specific tolerance or intolerance to pollution. Twelve of the species (1,657 individuals) were tolerant; four (87 individuals) were intolerant. Fish from sites in Mustang Bayou were scored using the regional index of biotic integrity (IBI) proposed for ecoregion 34. Fish communities supported a "high" aquatic life use for all surveys at sites M4-M6. Individual scores at M1 and M2 ranged from "intermediate" to "high" aquatic life use. Scores ranged from "limited" to "exceptional" at M3. Average IBI aquatic-life-use scores for fish assessments are "high" at all sites.

\section{References}

Brasher, A.M.D., Wolff, R.H., and Luton, C.D., 2003, Associations among land use, habitat characteristics, and invertebrate community structure in nine streams of the island of Oahu, Hawaii, 1999-2001: U.S. Geological Survey WaterResources Investigations Report 03-4256, 47 p.

East, J.W., and Sneck-Fahrer, D.A., 2004, Streamflow, waterquality, and biological data for three tributaries to Lake Houston near Houston, Texas, 2002-04: U.S. Geological Survey Data Series 142, 82 p. 
Fishman, M.J., ed., 1993, Methods of analysis by the U.S. Geological Survey National Water Quality LaboratoryDetermination of inorganic and organic constituents in water and fluvial sediments: U.S. Geological Survey OpenFile Report 93-125, 217 p.

Fishman, M.J., and Friedman, L.C., 1989, Methods for determination of inorganic substances in water and fluvial sediments: U.S. Geological Survey Techniques of WaterResources Investigations, book 5, chap. A1, 545 p.

Fram, M. 2006, Most fish kills in ponds are caused by low dissolved oxygen: Oklahoma State University, Oklahoma Cooperative Extension Service, accessed February 1, 2006, at http://biosystems.okstate.edu/waterquality/Projects_ Programs/Pond\%20management/Fish\%20kills-low\%20DO. htm

Garbarino, J.R., and Struzeski, T.M., 1998, Methods of analysis by the U.S. Geological Survey National Water Quality Laboratory-Determination of elements in whole-water digests using inductively coupled plasma-optical emission spectrometry and inductively coupled plasma-mass spectrometry: U.S. Geological Survey Open-File Report 98-165, $101 \mathrm{p}$.

Griffith, G.E., Bryce, S.A., Omernik, J.M., Comstock, J.A., Rogers, A.C., Harrison, B., Hatch, S.L., and Bezanson, D., 2004, Ecoregions of Texas (poster): U.S. Geological Survey, scale $1: 2,500,000$.

Guy, H.P., 1969, Laboratory theory and methods for sediment analysis: U.S. Geological Survey Techniques of WaterResources Investigations, book 5, chap. C1, 58 p.

Hem, J.D., 1985, Study and interpretation of the chemical characteristics of natural water ( $3 \mathrm{~d}$ ed.): U.S. Geological Survey Water-Supply Paper 2254, 263 p.

Hilsenhoff, W.L., 1988, Rapid field assessment of organic pollution with a family-level biotic index: Journal of the North American Benthological Society, v. 7, no. 1, p. 65-68.

Kelly, M., 2003, Receiving Water Assessment, New Bayou and Mustang Bayou, Brazoria County, Texas, in response to permit renewal of Walker Water Works, Inc., TPDES permit number 14039-001 and City of Alvin TPDES permit number 10005-001: Texas Commission on Environmental Quality, Region 12, 19 p.

Lester, G., 2004, Standards and methods: EcoAnalysts, Inc., accessed February 6, 2006, at http://www.ecoanalysts. com/stand.html

Linam, G.W., and Kleinsasser, L.J., 1998, Classification of Texas freshwater fishes into trophic and tolerance groups: Texas Parks and Wildlife Department, River Studies Report $14,8 \mathrm{p}$.
Linam, G.W., Kleinsasser, L.J., and Mayes, K.B., 2002, Regionalization of the index of biotic integrity for Texas streams: Texas Parks and Wildlife Department, Report 17, $26 \mathrm{p}$.

Lindley, C.E., Stewart, J.T., and Sandstrom, M.W., 1996, Determination of low concentrations of acetochlor in water by automated solid-phase extraction and gas chromatography with mass selective detection: Journal of AOAC (Association of Official Agricultural Chemists) International, v. 79, no. 4, p. 962-966.

Luedke, M., 1997, Receiving Water Assessment of Mustang Bayou, Brazoria County, in response to City of Hillcrest Village permit renewal, TNRCC permit number 10420-001: Texas Natural Resource Conservation Commission, Environmental Assessment Program, Region 12, 29 p.

Madsen, J.E., Sandstrom, M.W., and Zaugg, S.D., 2003, Methods of analysis by the U.S. Geological Survey National Water Quality Laboratory-A method supplement for the determination of fipronil and degradates in water by gas chromatography/mass spectrometry: U.S. Geological Survey Open-File Report 02-462, 11 p.

Mahler, B.J., and Van Metre, P.C., 2003, A simplified approach for monitoring hydrophobic organic contaminants associated with suspended sediment-Methodology and applications: Archives of Environmental Contamination and Toxicology, v. 44, p. 288-297.

Menhinick, E.F., 1964, A comparison of some speciesindividuals diversity indices applied to samples of field insects: Ecology, v. 45, p. 859-861.

Moring, J.B., 2003, Baseline assessment of fish communities, benthic macroinvertebrate communities, and stream habitat and land use, Big Thicket National Preserve, Texas, 1999-2001: U.S. Geological Survey Water-Resources Investigations Report 03-4270, 33 p.

Mueller, D.K., Martin, J.D., and Lopes, T.J., 1997, Qualitycontrol design for surface-water sampling in the National Water-Quality Assessment Program: U.S. Geological Survey Open-File Report 97-223, 17 p.

Myers, D.N., and Wilde, F.D., eds., 2003, National field manual for the collection of water-quality data-Biological indicators: U.S. Geological Survey Techniques of WaterResources Investigations, book 9, chap. A7, 163 p.

National Climatic Data Center, 2004, Climatological data, annual summary, Texas, 2004: v. 109, no. 13, accessed February 1, 2006, at http://www.ncdc.noaa.gov/oa/ncdc.html

National Climatic Data Center, 2005, Climatological data, Texas, January-August 2005: v. 110, nos. 1-8, accessed February 1, 2006, at http://www.ncdc.noaa.gov/oa/ncdc. html 
Noriega, M.C., Wydoski, D.S., and Foreman, W.T., 2004, Methods of analysis by the U.S. Geological Survey National Water Quality Laboratory-Determination of organochlorine pesticides and polychlorinated biphenyls in bottom and suspended sediment by gas chromatography with electroncapture detection: U.S. Geological Survey Water-Resources Investigations Report 03-4293, 46 p.

Oklahoma Water Resources Board, 2001, Unified protocols for beneficial use assignment for Oklahoma wadable streams: Oklahoma Water Resources Board Technical Report TRWQ2001-1, accessed on February 3, 2006, at http://www.owrb.state.ok.us/studies/reports/reports_pdf/ TR2001_1_Protocols_Wadable.pdf

Olson, M.C., Iverson, J.L., Furlong, E.T., and Schroeder, M.P., 2004, Methods of analysis by the U.S. Geological Survey National Water Quality Laboratory-Determination of polycyclic aromatic hydrocarbon compounds in sediment by gas chromatography/mass spectrometry: U.S. Geological Survey Water-Resources Investigations Report 03-4318, $45 \mathrm{p}$.

Patton, C.J., and Truitt, E.P., 1992, Methods of analysis by the U.S. Geological Survey National Water Quality Laboratory-Determination of total phosphorus by a Kjeldahl digestion method and an automated colorimetric finish that includes dialysis: U.S. Geological Survey Open-File Report 92-146, 39 p.

Patton, C.J., and Truitt, E.P., 2000, Methods of analysis by the U.S. Geological Survey National Water Quality Laboratory-Determination of ammonium plus organic nitrogen by a Kjeldahl digestion method and an automated photometric finish that includes digest cleanup by gas diffusion: U.S. Geological Survey Open-File Report 00-170, 31 p.

Porter, S.D., Cuffney, T.F., Gurtz, M.E., and Meador, M.R., 1993, Methods for collecting algal samples as part of the National Water-Quality Assessment Program: U.S. Geological Survey Open-File Report 93-409, 39 p.

Powers, S.L., Jones, G.L., Redinger, P., and Mayden, R.L., 2003, Habitat associations with upland stream fish assemblages in Bankhead National Forest, Alabama: Southeastern Naturalist, v. 2, p. 85-92.

Radtke, D.B., 1997, National field manual for the collection of water-quality data-Bottom material samples: U.S. Geological Survey Techniques of Water-Resources Investigations, book 9, chap. A8, 48 p.

Sandstrom, M.W., Stroppel, M.E., Foreman, W.T., and Schroeder, M.P., 2001, Methods of analysis by the U.S. Geological Survey National Water Quality LaboratoryDetermination of moderate-use pesticides and selected degradates in water by $\mathrm{C}-18$ solid-phase extraction and gas chromatography/mass spectrometry: U.S. Geological Survey Water-Resources Investigations Report 01-4098, 70 p.
Skrobialowski, S.C., Mize, S.V., and Demcheck, D.K., 2004, Environmental setting, water quality, and ecological indicators of surface-water quality in the Mermentau River Basin, southwestern Louisiana, 1998-2001: U.S. Geological Survey Water-Resources Investigations Report 03-4185, $73 \mathrm{p}$.

Stauffer, J.C., Goldstein, R.M., and Newman, R.M., 2000, Relationship of wooded riparian zones and runoff to fish community composition in agricultural streams: Canadian Journal of Fisheries and Aquatic Sciences, v. 57, p. 307316.

Stewart, K.W., and Stark, B.P., 1993, Nymphs of North American stonefly genera (Plecoptera): Denton, Tex., University of North Texas Press.

Texas Commission on Environmental Quality, 2003a, Guidance for assessing Texas surface and finished drinking water quality data, 2004: Texas Commission on Environmental Quality, 86 p.

Texas Commission on Environmental Quality, 2003b, Surface water quality monitoring procedures, volume 1 -Physical and chemical monitoring methods for water, sediment, and tissue: Texas Commission on Environmental Quality, Monitoring Operations Division, Report RG-415.

Texas Commission on Environmental Quality, 2005, Draft 2004 Texas 303(d) list (May 13, 2005): accessed January 26, 2006 at http://www.tceq.state.tx.us/assets/public/ compliance/monops/water/04twqi/04_303d.pdf

Texas Commission on Environmental Quality, 2006, Surface water quality monitoring procedures, volume 2-Methods for collecting and analyzing biological assemblage and habitat data: Texas Commission on Environmental Quality, Monitoring Operations Division, Report RG-416.

Texas Natural Resource Conservation Commission, 1999a, Use attainability analysis for Mustang Bayou, Brazoria County, Texas, segment 2432—Chocolate Bay: Texas Natural Resource Conservation Commission, Water Quality Division, $12 \mathrm{p}$.

Texas Natural Resource Conservation Commission, 1999b, Receiving water assessment procedures manual: Texas Natural Resource Conservation Commission, Water Quality Division, GI-253 [variously paged].

Texas State Climatologist, 2004, Texas climatic bulletin: Office of the Texas State Climatologist, College of Geosciences, Department of Atmospheric Sciences, Texas A\&M University, accessed February 14, 2006, at http://www. met.tamu.edu/osc/TXclimat.htm

Texas State Data Center, 2005, 2000 census-Population of Texas cities: Office of the State Demographer, Texas 
Population Estimates and Projections Program, accessed January 3, 2006, at http://www.tsl.state.tx.us/ref/abouttx/ popcity12000.html

Thomas, L.P., Peitz, D.G., and Carlisle, D.M., 2002, Macroinvertebrate monitoring as an indicator of water qualityStatus report for Wilson's Creek and Skegg's Branch, Wilson's Creek National Battlefield, 1998-2001: U.S. National Park Service, accessed February 9, 2006, at http://www.nature.nps.gov/im/units/htln/pdf/Reports/NPS\% 20WICR\%20Macroinvertebrate\%20Report\%202001\% 20DEC\%2020\%20Complete.pdf

U.S. Environmental Protection Agency, 1998, Microwave assisted acid digestion of sediments, sludges, soils, and oils (revision 1): U.S. Environmental Protection Agency Method 3051A, $25 \mathrm{p}$.

U.S. Environmental Protection Agency, 2004. 2004 edition of the drinking water standards and health advisories: U.S.
Environmental Protection Agency, Office of Water, EPA 822-R-04-005, 12 p.

U.S. Geological Survey, 1999, The quality of our Nation's waters-Nutrients and pesticides: U.S. Geological Survey Circular 1225, $82 \mathrm{p}$.

Vannote, R.L., Minshall, G.W., Cummins, K.W., Schell, J.R., and Cushing, C.E., 1980, The river continuum concept: Canadian Journal of Fisheries and Aquatic Sciences, v. 37, p. 130-137.

Zaugg, S.D., Sandstrom, M.W., Smith, S.G., and Fehlberg, K.M., 1995, Methods of analysis by the U.S. Geological Survey National Water Quality Laboratory-Determination of pesticides in water by $\mathrm{C}-18$ solid-phase extraction and capillary-column gas chromatography/mass spectrometry with selected-ion monitoring: U.S. Geological Survey Open-File Report 95-181, 60 p. 


\section{Appendix 1-Periodically Collected Water-Quality Properties and Constituents}


Blank Page 
Appendix 1. Periodically collected water-quality properties and constituents at six sites in Mustang Bayou near Houston, Texas, September 2004-August 2005.

[cfs, cubic feet per second; deg C, degrees Celsius; mm, millimeters; Hg, mercury; mg/L, milligrams per liter; unf (unfltrd), unfiltered; us/cm, microsiemens per centimeter; flt (fltrd), filtered; inc tit (incrm. titr.), incremental titration; $\mathrm{CaCO}_{3}$, calcium carbonate; --, property or constituent not analyzed for in this sample; Pt-Co, platinum-cobalt; NTRU, nephelometric turbidity ratio units; $\mathrm{N}$, nitrogen; $\mathrm{BOD}$, biochemical oxygen demand; $\mathrm{CBOD}$, carbonaceous biochemical oxygen demand; MF, membrane filtration; col/100 mL, colonies per 100 milliliters; P, phosphorus; org-N, organic nitrogen; ug/L, micrograms per liter]

08077905 Mustang Bayou at FM 2917 near Liverpool, TX (M1)

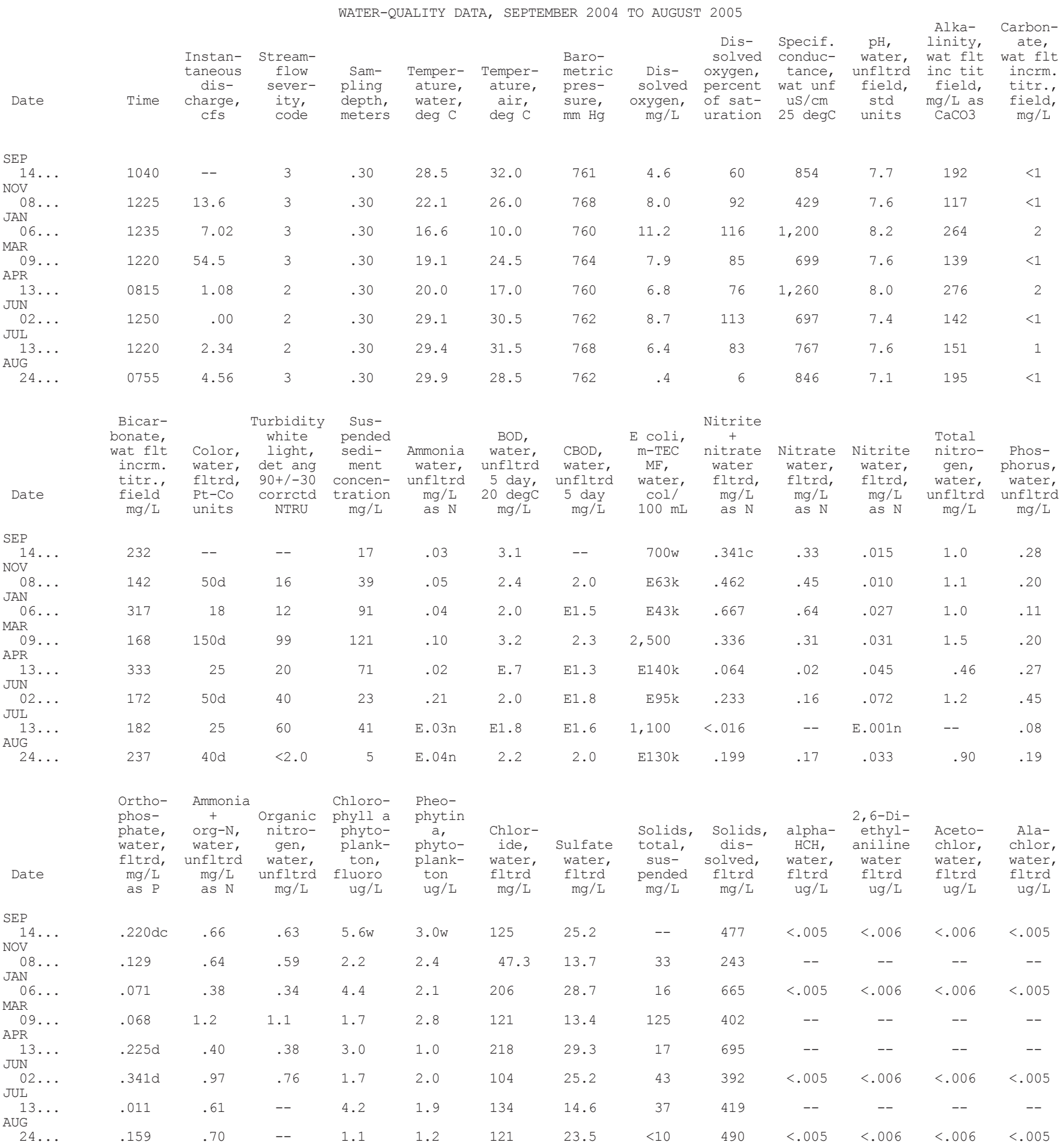




\section{Water-Quality, Sediment-Quality, Stream-Habitat, and Biological Data for Mustang Bayou, Texas, 2004-05}

Appendix 1. Periodically collected water-quality properties and constituents at six sites in Mustang Bayou near Houston, Texas, September 2004-August 2005-Continued.

08077905 Mustang Bayou at FM 2917 near Liverpool, TX (M1)--Continued

WATER-QUALITY DATA, SEPTEMBER 2004 TO AUGUST 2005

\begin{tabular}{|c|c|c|c|c|c|c|c|c|c|c|c|c|}
\hline ate & $\begin{array}{c}\text { Atra- } \\
\text { zine, } \\
\text { water, } \\
\text { fltrd } \\
\text { ug/L }\end{array}$ & $\begin{array}{c}\text { CIAT, } \\
\text { water, } \\
\text { fltrd } \\
\text { ug/L }\end{array}$ & $\begin{array}{l}\text { Azin- } \\
\text { phos-, } \\
\text { methyl, } \\
\text { water, } \\
\text { fltrd } \\
\text { ug/L }\end{array}$ & $\begin{array}{l}\text { Ben- } \\
\text { flur- } \\
\text { alin, } \\
\text { water, } \\
\text { fltrd } \\
\text { ug/L }\end{array}$ & $\begin{array}{c}\text { Butyl- } \\
\text { ate, } \\
\text { water, } \\
\text { fltrd } \\
\text { ug/L }\end{array}$ & $\begin{array}{c}\text { Car- } \\
\text { baryl, } \\
\text { water, } \\
\text { fltrd } \\
\text { ug/L }\end{array}$ & $\begin{array}{c}\text { Carbo- } \\
\text { furan, } \\
\text { water, } \\
\text { fltrd } \\
\text { ug/L }\end{array}$ & $\begin{array}{c}\text { Chlor- } \\
\text { pyrifos, } \\
\text { water, } \\
\text { fltrd } \\
\text { ug/L }\end{array}$ & $\begin{array}{c}\text { cis- } \\
\text { Per- } \\
\text { methrin, } \\
\text { water, } \\
\text { fltrd } \\
\text { ug/L }\end{array}$ & $\begin{array}{c}\text { Cyana- } \\
\text { zine, } \\
\text { water, } \\
\text { fltrd } \\
\text { ug/L }\end{array}$ & $\begin{array}{c}\text { DCPA, } \\
\text { water, } \\
\text { fltrd } \\
\text { ug/L }\end{array}$ & $\begin{array}{c}\text { Diazi- } \\
\text { non, } \\
\text { water, } \\
\text { fltrd } \\
\text { ug/L }\end{array}$ \\
\hline
\end{tabular}

\begin{tabular}{|c|c|c|c|c|c|c|c|c|c|c|c|c|c|}
\hline SEP & & & & & & & & & & & & & \\
\hline$\underset{\text { NOV }}{14 \ldots}$ & .087 & E.015 & $<.050$ & $<.010$ & $<.004$ & $<.041$ & $<.020$ & $<.005$ & $<.006$ & $<.018$ & $<.003$ & $<.005$ & $<.009$ \\
\hline$\underset{\text { JAN }}{08} \ldots$ & -- & -- & -- & -- & -- & -- & -- & -- & -- & -- & -- & -- & -- \\
\hline$\underset{M A R}{06 \ldots}$ & .090 & E.008 & $<.050$ & $<.010$ & $<.004$ & $<.041$ & $<.020$ & $<.005$ & $<.006$ & $<.018$ & $<.003$ & $<.005$ & $<.009$ \\
\hline$\underset{A P R}{09} \cdots$ & -- & -- & -- & -- & -- & -- & -- & -- & -- & -- & -- & -- & -- \\
\hline${ }_{\text {JUN }}^{13} \ldots$ & -- & -- & -- & -- & -- & -- & -- & -- & -- & -- & -- & -- & -- \\
\hline$\underset{\text { JUL }}{02 \ldots}$ & .576 & E.062mc & $<.050 \mathrm{mc}$ & $<.010$ & $<.004$ & E.022mnc & $<.020 \mathrm{mc}$ & $<.005$ & $<.006$ & $<.018$ & $<.003$ & $<.005$ & $<.009$ \\
\hline$\underset{\text { AUG }}{13} \ldots$ & -- & -- & -- & -- & -- & -- & -- & -- & -- & -- & -- & -- & -- \\
\hline $24 \ldots$ & .118 & E.011mc & $<.050 \mathrm{mc}$ & $<.010$ & $<.004$ & $<.041 \mathrm{mc}$ & $<.020 \mathrm{mc}$ & $<.005$ & $<.006$ & $<.018$ & $<.003$ & $<.005$ & $<.009$ \\
\hline
\end{tabular}

SEP

$14 \ldots$

NOV
$08 \ldots$

JAN

$06 \ldots$

MAR

APR

$13 \ldots$

JUN
$02 \ldots$

JUL $13 \ldots$

AUG

$24 \ldots$
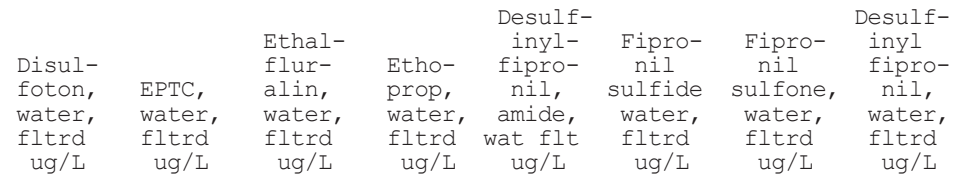

Fipro-

nil, Eonofos,

water, water,

Mala-

water, water, water, water, amide, water, water, water,

$\mathrm{ug} / \mathrm{L} \quad \mathrm{ug} / \mathrm{L} \quad \mathrm{ug} / \mathrm{L}$

ug/L ug/L

$\mathrm{ug} / \mathrm{L} \quad \mathrm{ug} / \mathrm{L}$

$<.02$

$<.004$

$<.009$

$<.005$

E. $002 t$

E. 008n

E.009t

E.005t

$\mathrm{ug} / \mathrm{L}$

flerd

water,

Linuron, thion,

-- $\quad$--

$<.02<.004$

$<.009$

$<.005$

$<.029$

E.004t E.004t $<.012$

E.006t $<.003$

$<.004$

ug/L $\quad$ fltrd

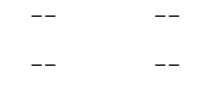

$<.02$

$<.004$

$<.009$

$<.005$ E.004mtc

.030

E. 017n

.014

E. $033 \mathrm{mc}<.003$

$<.00$

$<.035$

$<.027$

$<.02 \mathrm{mc}$

$<.004$

$<.009$

$<.005<.029$ mc

$<.013$

$<.024$

$<.012$

$<.016 \mathrm{mc}<.003$

$<.00$

$<.035$

$<.027$

para- Metola-

thion, chlor,

water, water,

Metri
buzin
water,
fltrd,

Moli-

Naprop-
amide,
water,

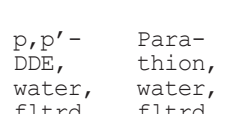

Peb- Pendi-

Date

ug/

ug/L ug/L

water,

ftrd, fltrd,

fltrd, fltrd,

Peb-
ulate,
water,

meth- Prome- Propy- Propawater, water, water, water, water, SEP

SEP
$14 \ldots$
NOV

$<.01$

$<.013$

$<.006$

$<.003$

$<.007$

$\mathrm{gg} / \mathrm{L} \quad \mathrm{ug} / \mathrm{L}$

fltrd,

ug/r fltrd,

$\mathrm{ug} / \mathrm{L}$

$\mathrm{ug} / \mathrm{L}$

$\mathrm{g} / \mathrm{L}$ fltrd,

$08 \ldots$

JAN
$06 \ldots$

MAR

09...

APR
$13 \ldots$

JUN
$02 \ldots$

JUL $13 \ldots$

$--\quad-$

$<.01$

$<.006$

$<.006$

--

$--$

$<.00$

$<.010$

$<.004$

$<.022$

$<.011$

$<.01$

$<.004<.025$

AUG
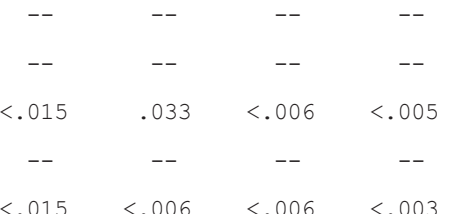

$<.007$

$<.003<.010$

$<.004$

$<.022$

$<.011$

E. 01

$<.004<.025$

$<.015$

$<.006<.005<.007$

$<.003$

$<.004$

$<.022$

$<.011$

.01

$<.004<.025$

$24 \ldots$

$<.006<.003$

$<.007$

$<.003<.010$

$<.004$

$<.022<.011$

$<.01<.004<.025$ 
Appendix 1. Periodically collected water-quality properties and constituents at six sites in Mustang Bayou near Houston, Texas, September 2004-August 2005-Continued.

\begin{tabular}{|c|c|c|c|c|c|c|c|c|}
\hline \multirow[b]{2}{*}{$\begin{array}{l}\text { Pro- } \\
\text { panil, } \\
\text { water, } \\
\text { fltrd } \\
\text { ug/L }\end{array}$} & \multicolumn{2}{|c|}{ WATER-QUALITY DATA, } & \multicolumn{2}{|c|}{ SEPTEMBER 2004} & TO AUGUST & \multicolumn{2}{|l|}{2005} & \multirow[b]{2}{*}{$\begin{array}{l}\text { Tri- } \\
\text { flur- } \\
\text { alin, } \\
\text { water, } \\
\text { fltrd } \\
\text { ug/L }\end{array}$} \\
\hline & $\begin{array}{l}\text { Propar- } \\
\text { gite, } \\
\text { water, } \\
\text { fltrd } \\
\text { ug/L }\end{array}$ & $\begin{array}{l}\text { Sima- } \\
\text { zine, } \\
\text { water, } \\
\text { fltrd } \\
\text { ug/L }\end{array}$ & $\begin{array}{l}\text { Tebu- } \\
\text { thiuron, } \\
\text { water, } \\
\text { fltrd } \\
\text { ug/L }\end{array}$ & $\begin{array}{c}\text { Terbu- } \\
\text { cil, } \\
\text { water, } \\
\text { fltrd } \\
\text { ug/L }\end{array}$ & $\begin{array}{l}\text { Terbu- } \\
\text { fos, } \\
\text { water, } \\
\text { fltrd } \\
\text { ug/L }\end{array}$ & $\begin{array}{c}\text { Thio- } \\
\text { bencarb, } \\
\text { water, } \\
\text { fltrd } \\
\text { ug/L }\end{array}$ & $\begin{array}{l}\text { Tri- } \\
\text { allate, } \\
\text { water, } \\
\text { fltrd } \\
\text { ug/L }\end{array}$ & \\
\hline$<.011$ & $<.02$ & $<.015$ & .03 & $<.034$ & $<.02$ & $<.010$ & $<.002$ & $<.009$ \\
\hline-- & -- & -- & -- & -- & -- & -- & -- & -- \\
\hline$<.011$ & $<.02$ & E.005n & .08 & $<.034$ & $<.02$ & $<.010$ & $<.006$ & $<.009$ \\
\hline-- & -- & -- & -- & -- & -- & -- & -- & -- \\
\hline-- & -- & -- & -- & -- & -- & -- & -- & -- \\
\hline$<.011$ & $<.02$ & .014 & .03 & $<.034 \mathrm{mc}$ & $<.02$ & $<.010$ & $<.006$ & $<.009$ \\
\hline-- & -- & -- & -- & -- & -- & -- & -- & -- \\
\hline$<.011$ & $<.02$ & $<.005$ & .03 & $<.034 \mathrm{mc}$ & $<.02$ & $<.010$ & $<.006$ & $<.009$ \\
\hline
\end{tabular}




\section{Water-Quality, Sediment-Quality, Stream-Habitat, and Biological Data for Mustang Bayou, Texas, 2004-05}

Appendix 1. Periodically collected water-quality properties and constituents at six sites in Mustang Bayou near Houston, Texas, September 2004-August 2005-Continued.

08077895 Mustang Bayou at CR 168 near Alvin, TX (M2)

WATER-QUALITY DATA, SEPTEMBER 2004 TO AUGUST 2005

\begin{tabular}{|c|c|c|c|c|c|c|c|c|c|c|c|c|c|}
\hline Date & Time & $\begin{array}{c}\text { Instan- } \\
\text { taneous } \\
\text { dis- } \\
\text { charge, } \\
\text { cfs }\end{array}$ & $\begin{array}{c}\text { Stream- } \\
\text { flow } \\
\text { sever- } \\
\text { ity, } \\
\text { code }\end{array}$ & $\begin{array}{l}\text { Sam- } \\
\text { pling } \\
\text { depth, } \\
\text { meters }\end{array}$ & $\begin{array}{c}\text { Temper- } \\
\text { ature, } \\
\text { water, } \\
\text { deg C }\end{array}$ & $\begin{array}{c}\text { Temper- } \\
\text { ature, } \\
\text { air, } \\
\text { deg C }\end{array}$ & $\begin{array}{l}\text { Baro- } \\
\text { metric } \\
\text { pres- } \\
\text { sure, } \\
\text { mm Hg }\end{array}$ & $\begin{array}{c}\text { Dis- } \\
\text { solved } \\
\text { oxygen, } \\
\text { mg/L }\end{array}$ & $\begin{array}{c}\text { Dis- } \\
\text { solved } \\
\text { oxygen, } \\
\text { percent } \\
\text { of sat- } \\
\text { uration }\end{array}$ & $\begin{array}{c}\text { Specif. } \\
\text { conduc- } \\
\text { tance, } \\
\text { wat unf } \\
\text { uS } / \mathrm{cm} \\
25 \text { degc }\end{array}$ & $\begin{array}{l}\text { pH, } \\
\text { water, } \\
\text { unfltrd } \\
\text { field, } \\
\text { std } \\
\text { units }\end{array}$ & $\begin{array}{l}\text { Alka- } \\
\text { linity, } \\
\text { wat flt } \\
\text { inc tit } \\
\text { field, } \\
\text { mg/L as } \\
\text { CaCo3 }\end{array}$ & $\begin{array}{c}\text { Carbon- } \\
\text { ate, } \\
\text { wat flt } \\
\text { incrm. } \\
\text { titr. } \\
\text { field, } \\
\text { mg/L }\end{array}$ \\
\hline $\begin{array}{l}\text { SEP } \\
\quad 13 \ldots \\
\text { NOV }\end{array}$ & 1130 & 9.44 & 3 & .30 & 29.3 & 33.0 & 766 & 8.6 & 112 & 532 & 8.0 & 163 & $E<1$ \\
\hline $\begin{array}{c}08 \ldots \\
\text { JAN }\end{array}$ & 1145 & 19.9 & 3 & .30 & 20.7 & 26.0 & 769 & 7.9 & 87 & 367 & 7.5 & 112 & $<1$ \\
\hline $\begin{array}{l}06 \ldots \\
\text { MAR }\end{array}$ & 1115 & 13.5 & 3 & .12 & 16.6 & 9.0 & 761 & 8.6 & 89 & 1,260 & 7.8 & 246 & 1 \\
\hline $\begin{array}{c}09 \\
\text { APR }\end{array}$ & 1125 & 126 & 3 & .30 & 18.7 & 21.0 & 762 & 8.3 & 89 & 485 & 7.5 & 111 & $<1$ \\
\hline$\underset{\text { JUN }}{13} \ldots$ & 0930 & 14.7 & 2 & .13 & 21.8 & 20.5 & 762 & 9.8 & 113 & 1,360 & 8.0 & 253 & 2 \\
\hline $\begin{array}{l}02 \ldots \\
\text { JUL }\end{array}$ & 1200 & 7.10 & 2 & .24 & 29.9 & 29.5 & 762 & 14.2 & 188 & 661 & 8.2 & 188 & 4 \\
\hline$\underset{\text { AUG }}{13} \ldots$ & 1140 & 4.17 & 2 & .08 & 31.7 & 33.0 & 767 & 14.6 & 198 & 542 & 8.4 & 173 & 5 \\
\hline $24 \ldots$ & 0905 & 11.3 & 3 & .12 & 30.0 & 29.5 & 762 & 5.2 & 69 & 542 & 7.5 & 161 & $<1$ \\
\hline Date & $\begin{array}{c}\text { Bicar- } \\
\text { bonate, } \\
\text { wat flt } \\
\text { incrm. } \\
\text { titr., } \\
\text { field, } \\
\text { mg/L }\end{array}$ & $\begin{array}{l}\text { Color, } \\
\text { water, } \\
\text { fltrd, } \\
\text { Pt-co } \\
\text { units }\end{array}$ & $\begin{array}{c}\text { Turbidity } \\
\text { white } \\
\text { light, } \\
\text { det ang } \\
90+/-30 \\
\text { corrctd } \\
\text { NTRU }\end{array}$ & $\begin{array}{l}\text { Sus- } \\
\text { pended } \\
\text { sedi- } \\
\text { ment } \\
\text { concen- } \\
\text { tration } \\
\text { mg/L }\end{array}$ & $\begin{array}{c}\text { Ammonia } \\
\text { water, } \\
\text { unfltrd } \\
\text { mg/L } \\
\text { as N }\end{array}$ & $\begin{array}{c}\text { BOD, } \\
\text { water, } \\
\text { unfltrd } \\
5 \text { day, } \\
20 \text { degc } \\
\text { mg/L }\end{array}$ & $\begin{array}{c}\text { CBOD, } \\
\text { water, } \\
\text { unfltrd } \\
5 \text { day, } \\
\text { mg/L }\end{array}$ & $\begin{array}{c}\text { E coli, } \\
\text { m-TEC } \\
\text { MF, } \\
\text { water, } \\
\text { col/ } \\
100 \mathrm{~mL}\end{array}$ & $\begin{array}{c}\text { Nitrite } \\
+ \\
\text { nitrate } \\
\text { water } \\
\text { fltrd, } \\
\text { mg/L } \\
\text { as N }\end{array}$ & $\begin{array}{c}\text { Nitrate } \\
\text { water, } \\
\text { fltrd, } \\
\text { mg/L } \\
\text { as N }\end{array}$ & $\begin{array}{c}\text { Nitrite } \\
\text { water, } \\
\text { fltrd, } \\
\text { mg/L } \\
\text { as N }\end{array}$ & $\begin{array}{l}\text { Total } \\
\text { nitro- } \\
\text { gen, } \\
\text { water, } \\
\text { unfltrd } \\
\text { mg/L }\end{array}$ & $\begin{array}{c}\text { Phos- } \\
\text { phorus, } \\
\text { water, } \\
\text { unfltrd } \\
\text { mg/L }\end{array}$ \\
\hline SEP & & & & & & & & & & & & & \\
\hline$\underset{\text { NOV }}{13 \ldots}$ & E198 & -- & -- & 19 & .01 & 2.3 & -- & $\mathrm{E} 48 \mathrm{k}$ & .075 & .07 & .004 & .49 & .12 \\
\hline$\underset{\text { JAN }}{08 \ldots}$ & 136 & $50 d$ & 36 & 48 & .05 & 2.5 & 2.2 & 200 & .144 & .14 & .008 & .71 & .14 \\
\hline $\begin{array}{l}06 \ldots \\
\text { MAR }\end{array}$ & 298 & 12 & 12 & 60 & .01 & $\mathrm{E} 1.7$ & $\mathrm{E} 1.6$ & 220 & .083 & .07 & .009 & -- & $<.04$ \\
\hline $\begin{array}{c}09 \\
\text { APR }\end{array}$ & 135 & $200 d$ & 110 & 131 & .08 & 3.7 & 3.0 & 1,800 & .134 & .12 & .013 & 1.4 & .20 \\
\hline$\underset{\text { JUN }}{13 \ldots}$ & 305 & 20 & 2.3 & 79 & .02 & E1. 4 & $\mathrm{E} 1.1$ & $\mathrm{E} 100 \mathrm{k}$ & .018 & .02 & .002 & .30 & E.04n \\
\hline $\begin{array}{l}02 \ldots \\
\text { JUL }\end{array}$ & 222 & 25 & 5.9 & 23 & $<.04$ & E1.3 & $\mathrm{E} 1.1$ & E16k & .016 & .01 & .009 & .37 & .10 \\
\hline $\begin{array}{c}13 \ldots \\
\text { AUG }\end{array}$ & 200 & 18 & 4.9 & 8 & $\mathrm{E} .02 \mathrm{n}$ & E1.3 & E1.3 & 230 & .030 & .02 & .009 & .36 & .14 \\
\hline $24 \ldots$ & 195 & 25 & 6.1 & 11 & E.04n & E1. 7 & $\mathrm{E} 1.4$ & 140 & .095 & .08 & .015 & .50 & .11 \\
\hline Date & $\begin{array}{l}\text { Ortho- } \\
\text { phos- } \\
\text { phate, } \\
\text { water, } \\
\text { fltrd, } \\
\text { mg/L } \\
\text { as P }\end{array}$ & $\begin{array}{c}\text { Ammonia } \\
+ \\
\text { org-N, } \\
\text { water, } \\
\text { unfltrd } \\
\text { mg/L } \\
\text { as N }\end{array}$ & $\begin{array}{l}\text { Organic } \\
\text { nitro- } \\
\text { gen, } \\
\text { water, } \\
\text { unfltrd } \\
\text { mg/L }\end{array}$ & $\begin{array}{l}\text { Chloro- } \\
\text { phyll a } \\
\text { phyto- } \\
\text { plank- } \\
\text { ton, } \\
\text { fluoro } \\
\text { ug/L }\end{array}$ & $\begin{array}{l}\text { Pheo- } \\
\text { phytin } \\
\text { a, } \\
\text { phyto- } \\
\text { plank- } \\
\text { ton } \\
\text { ug/L }\end{array}$ & $\begin{array}{l}\text { Chlor- } \\
\text { ide, } \\
\text { water, } \\
\text { fltrd } \\
\text { mg/L }\end{array}$ & $\begin{array}{c}\text { Sulfate } \\
\text { water, } \\
\text { fltrd } \\
\text { mg/L }\end{array}$ & $\begin{array}{l}\text { Solids, } \\
\text { total, } \\
\text { sus- } \\
\text { pended } \\
\text { mg/L }\end{array}$ & $\begin{array}{l}\text { Solids, } \\
\text { dis- } \\
\text { solved, } \\
\text { fltrd } \\
\mathrm{mg} / \mathrm{L}\end{array}$ & $\begin{array}{c}\text { alpha- } \\
\text { HCH, } \\
\text { water, } \\
\text { fltrd } \\
\text { ug/L }\end{array}$ & $\begin{array}{c}2,6-D i- \\
\text { ethyl- } \\
\text { aniline } \\
\text { water } \\
\text { fltrd } \\
\text { ug/L }\end{array}$ & $\begin{array}{l}\text { Aceto- } \\
\text { chlor, } \\
\text { water, } \\
\text { fltrd } \\
\text { ug/L }\end{array}$ & $\begin{array}{c}\text { Ala- } \\
\text { chlor, } \\
\text { water, } \\
\text { fltrd } \\
\text { ug/L }\end{array}$ \\
\hline $\begin{array}{l}\mathrm{SEP} \\
13 \ldots\end{array}$ & $.075 c$ & .41 & .40 & 2.5 & 2.0 & 48.4 & 17.9 & -- & 312 & $<.005$ & $<.006$ & $<.006$ & $<.005$ \\
\hline $\begin{array}{l}\text { NOV } \\
08 \ldots \\
\text { JAN }\end{array}$ & .079 & .57 & .51 & 1.8 & 1.8 & 32.8 & 11.4 & 35 & 212 & -- & -- & -- & -- \\
\hline $\begin{array}{c}06 \ldots \\
\text { MAR }\end{array}$ & .019 & E.09n & -- & 3.0 & 2.4 & 235 & 25.2 & 28 & 697 & $<.005$ & $<.006$ & $<.006$ & $<.005$ \\
\hline$\underset{A P R}{09} \ldots$ & .057 & 1.3 & 1.2 & 1.9 & 3.5 & 74.7 & 9.5 & 117 & 295 & -- & -- & -- & -- \\
\hline$\underset{\text { JUN }}{13} \ldots$ & .018 & .28 & .27 & .8 & .6 & 262 & 24.7 & $<10$ & 732 & -- & -- & -- & -- \\
\hline$\underset{\text { JUL }}{02 \ldots}$ & .022 & .35 & -- & 1.8 & 1.0 & 75.2 & 19.9 & 10 & 382 & $<.005$ & $<.006$ & $<.006$ & $<.005$ \\
\hline$\underset{\text { AUG }}{13} \ldots$ & .051 & .33 & -- & 2.5 & 2.9 & 57.6 & 13.9 & $<10$ & 313 & -- & -- & -- & -- \\
\hline $24 \ldots$ & .078 & .41 & -- & 2.0 & 1.8 & 63.1 & 14.0 & $<10$ & 307 & $<.005$ & $<.006$ & $<.006$ & $<.005$ \\
\hline
\end{tabular}


Appendix 1. Periodically collected water-quality properties and constituents at six sites in Mustang Bayou near Houston, Texas, September 2004-August 2005-Continued.

08077895 Mustang Bayou at CR 168 near Alvin, TX (M2)--Continued

WATER-QUALITY DATA, SEPTEMBER 2004 TO AUGUST 2005

\begin{tabular}{|c|c|c|c|c|c|c|c|c|c|c|c|c|c|}
\hline Date & $\begin{array}{l}\text { Atra- } \\
\text { zine, } \\
\text { water, } \\
\text { fltrd } \\
\text { ug/L }\end{array}$ & $\begin{array}{l}\text { CIAT, } \\
\text { water, } \\
\text { fltrd } \\
\text { ug/L }\end{array}$ & $\begin{array}{l}\text { Azin- } \\
\text { phos-, } \\
\text { methyl, } \\
\text { water, } \\
\text { fltrd } \\
\text { ug/L }\end{array}$ & $\begin{array}{l}\text { Ben- } \\
\text { flur- } \\
\text { alin, } \\
\text { water, } \\
\text { fltrd } \\
\text { ug/L }\end{array}$ & $\begin{array}{l}\text { Butyl- } \\
\text { ate, } \\
\text { water, } \\
\text { fltrd } \\
\text { ug/L }\end{array}$ & $\begin{array}{c}\text { Car- } \\
\text { baryl, } \\
\text { water, } \\
\text { fltrd } \\
\text { ug/L }\end{array}$ & $\begin{array}{l}\text { Carbo- } \\
\text { furan, } \\
\text { water, } \\
\text { fltrd } \\
\text { ug/L }\end{array}$ & $\begin{array}{l}\text { Chlor- } \\
\text { pyrifos, } \\
\text { water, } \\
\text { fltrd } \\
\text { ug/L }\end{array}$ & $\begin{array}{l}\text { cis- } \\
\text { Per- } \\
\text { methrin, } \\
\text { water, } \\
\text { fltrd } \\
\text { ug/L }\end{array}$ & $\begin{array}{c}\text { Cyana- } \\
\text { zine, } \\
\text { water, } \\
\text { fltrd } \\
\text { ug/L }\end{array}$ & $\begin{array}{l}\text { DCPA, } \\
\text { water, } \\
\text { fltrd } \\
\text { ug/L }\end{array}$ & $\begin{array}{l}\text { Diazi- } \\
\text { non, } \\
\text { water, } \\
\text { fltrd } \\
\text { ug/L }\end{array}$ & $\begin{array}{l}\text { Diel- } \\
\text { drin, } \\
\text { water, } \\
\text { fltrd } \\
\text { ug/L }\end{array}$ \\
\hline $\begin{array}{l}\mathrm{SEP} \\
13 \ldots\end{array}$ & 071 & & $<.050$ & $<.010$ & & & & & $<.006$ & $<018$ & & $<005$ & $<.009$ \\
\hline NOV & $.0 / 1$ & E.008 & .000 & .010 & $<.004$ & $<.041$ & $<.020$ & $<.005$ & .000 & .010 & $<.003$ &. .000 & -.009 \\
\hline$\underset{\text { JAN }}{08} \cdots$ & -- & -- & -- & -- & -- & -- & -- & -- & -- & -- & -- & -- & -- \\
\hline $\begin{array}{l}06 \ldots \\
\operatorname{MAR}\end{array}$ & .098 & E.009 & $<.050$ & $<.010$ & $<.004$ & $<.041$ & $<.020$ & $<.005$ & $<.006$ & $<.018$ & $<.003$ & $<.005$ & $<.009$ \\
\hline $\begin{array}{c}09 \ldots \\
\text { APR }\end{array}$ & -- & -- & -- & -- & -- & -- & -- & -- & -- & -- & -- & -- & -- \\
\hline${ }_{\text {JUN }}^{13} \cdots$ & -- & -- & -- & -- & -- & -- & -- & -- & -- & -- & -- & -- & -- \\
\hline$\underset{\text { JUL }}{02 \ldots}$ & .148 & E. $024 \mathrm{mc}$ & $<.050 \mathrm{mc}$ & $<.010$ & $<.004$ & $<.041 \mathrm{mc}$ & $<.020 \mathrm{mc}$ & $<.005$ & $<.006$ & $<.018$ & $<.003$ & $<.005$ & $<.009$ \\
\hline${ }_{A U G}^{13} \ldots$ & -- & -- & -- & -- & -- & -- & -- & -- & -- & -- & -- & -- & -- \\
\hline $24 \ldots$ & .238 & $\mathrm{E} .011 \mathrm{mc}$ & $<.050 \mathrm{mc}$ & $<.010$ & $<.004$ & $<.041 \mathrm{mc}$ & $<.020 \mathrm{mc}$ & $<.005$ & $<.006$ & $<.018$ & $<.003$ & $<.005$ & $<.009$ \\
\hline Date & $\begin{array}{l}\text { Disul- } \\
\text { foton, } \\
\text { water, } \\
\text { fltrd } \\
\text { ug/L }\end{array}$ & $\begin{array}{l}\text { EPTC, } \\
\text { water, } \\
\text { fltrd } \\
\text { ug/L }\end{array}$ & $\begin{array}{l}\text { Ethal- } \\
\text { flur- } \\
\text { alin, } \\
\text { water, } \\
\text { fltrd } \\
\text { ug/L }\end{array}$ & $\begin{array}{l}\text { Etho- } \\
\text { prop, } \\
\text { water, } \\
\text { fltrd } \\
\text { ug/L }\end{array}$ & $\begin{array}{l}\text { Desulf- } \\
\text { inyl- } \\
\text { fipro- } \\
\text { nil, } \\
\text { amide, } \\
\text { wat flt } \\
\text { ug/L }\end{array}$ & $\begin{array}{l}\text { Fipro- } \\
\text { nil } \\
\text { sulfide s } \\
\text { water, } \\
\text { fltrd } \\
\text { ug/L }\end{array}$ & $\begin{array}{l}\text { Fipro- } \\
\text { nil } \\
\text { sulfone, } \\
\text { water, } \\
\text { fltrd } \\
\text { ug/L }\end{array}$ & $\begin{array}{l}\text { Desulf- } \\
\text { inyl } \\
\text { fipro- } \\
\text { nil, } \\
\text { water, } \\
\text { fltrd } \\
\text { ug/L }\end{array}$ & $\begin{array}{l}\text { Fipro- } \\
\text { nil, } \\
\text { water, } \\
\text { fltrd } \\
\text { ug/L }\end{array}$ & $\begin{array}{l}\text { Conofos, } \\
\text { water, } \\
\text { fltrd } \\
\text { ug/L }\end{array}$ & $\begin{array}{l}\text { Lindane, } \\
\text { water, } \\
\text { fltrd } \\
\text { ug/L }\end{array}$ & $\begin{array}{l}\text { Linuron, } \\
\text { water, } \\
\text { fltrd } \\
\text { ug/L }\end{array}$ & $\begin{array}{l}\text { Mala- } \\
\text { thion, } \\
\text { water, } \\
\text { fltrd } \\
\text { ug/L }\end{array}$ \\
\hline $\begin{array}{l}\mathrm{SEP} \\
13 \ldots\end{array}$ & & & & & & & & & & & & & \\
\hline NOV & $<.02$ & $<.004$ & $<.009$ & $<.005$ & $<.029$ & $<.013$ & $<.024$ & $<.012$ & $<.016$ & $<.003$ & $<.004$ & $<.035$ & $<.027$ \\
\hline$\underset{\text { JAN }}{08} \cdots$ & -- & -- & -- & -- & -- & -- & -- & -- & -- & -- & -- & -- & -- \\
\hline $\begin{array}{l}06 \ldots \\
\operatorname{MAR}\end{array}$ & $<.02$ & $<.004$ & $<.009$ & $<.005$ & $<.029$ & $<.013$ & $<.024$ & $<.012$ & $<.016$ & $<.003$ & $<.004$ & $<.035$ & $<.027$ \\
\hline$\underset{A P R}{09} \cdots$ & -- & -- & -- & -- & -- & -- & -- & -- & -- & -- & -- & -- & -- \\
\hline${ }_{\text {JUN }}^{13} \cdots$ & -- & -- & -- & -- & -- & -- & -- & -- & -- & -- & -- & -- & -- \\
\hline $\begin{array}{l}02 \ldots \\
\text { JUL }\end{array}$ & $<.02$ & $<.004$ & $<.009$ & $<.005$ & $<.029 \mathrm{mc}$ & .015 & E.009t & E.006t & E.008mtc & $=<.003$ & $<.004$ & $<.035$ & $<.027$ \\
\hline $\begin{array}{l}13 \\
\text { AUG }\end{array}$ & -- & -- & -- & -- & -- & -- & -- & -- & -- & -- & -- & -- & -- \\
\hline $24 \ldots$ & $<.02 \mathrm{mc}$ & $<.014$ & $<.009$ & $<.005$ & $<.029 \mathrm{mc}$ & E.004t & $<.024$ & $<.012$ & $<.016 \mathrm{mc}$ & $<.003$ & $<.004$ & $<.035$ & $<.027$ \\
\hline Date & $\begin{array}{l}\text { Methyl } \\
\text { para- } \\
\text { thion, } \\
\text { water, } \\
\text { fltrd, } \\
\text { ug/L }\end{array}$ & $\begin{array}{c}\text { Metola- } \\
\text { chlor, } \\
\text { water, } \\
\text { fltrd, } \\
\text { ug/L }\end{array}$ & $\begin{array}{l}\text { Metri- } \\
\text { buzin, } \\
\text { water, } \\
\text { fltrd, } \\
\text { ug/L }\end{array}$ & $\begin{array}{l}\text { Moli- } \\
\text { nate, } \\
\text { water, } \\
\text { fltrd, } \\
\text { ug/L }\end{array}$ & $\begin{array}{l}\text { Naprop- } \\
\text { amide, } \\
\text { water, } \\
\text { fltrd, } \\
\text { ug/L }\end{array}$ & $\begin{array}{l}\text { p, p'- } \\
\text { DDE, } \\
\text { water, } \\
\text { fltrd, } \\
\text { ug/L }\end{array}$ & $\begin{array}{l}\text { Para- } \\
\text { thion, } \\
\text { water, } \\
\text { fltrd, } \\
\text { ug/L }\end{array}$ & $\begin{array}{l}\text { Peb- } \\
\text { ulate, } \\
\text { water, } \\
\text { fltrd, } \\
\text { ug/L }\end{array}$ & $\begin{array}{l}\text { Pendi- } \\
\text { meth- } \\
\text { alin, } \\
\text { water, } \\
\text { fltrd, } \\
\text { ug/L }\end{array}$ & $\begin{array}{c}\text { Phorate, } \\
\text { water, } \\
\text { fltrd, } \\
\text { ug/L }\end{array}$ & $\begin{array}{c}\text { Prome- } \\
\text { ton, } \\
\text { water, } \\
\text { fltrd, } \\
\text { ug/L }\end{array}$ & $\begin{array}{l}\text { Propy- } \\
\text { zamide, } \\
\text { water, } \\
\text { fltrd, } \\
\text { ug/L }\end{array}$ & $\begin{array}{l}\text { Propa- } \\
\text { chlor, } \\
\text { water } \\
\text { fltrd, } \\
\text { ug/L }\end{array}$ \\
\hline SEP & & & & & & & & & & & & & \\
\hline$\stackrel{13}{13}$ & $<.015$ & $<.013$ & $<.006$ & $<.003$ & $<.007$ & $<.003$ & $<.010$ & $<.004$ & $<.022$ & $<.011$ & .01 & $<.004$ & $<.025$ \\
\hline$\underset{\text { JAN }}{08} \cdots$ & -- & -- & -- & -- & -- & -- & -- & -- & -- & -- & -- & -- & -- \\
\hline$\underset{\operatorname{MAR}}{06 \ldots}$ & $<.015$ & $<.006$ & $<.006$ & $<.003$ & $<.007$ & $<.003$ & $<.010$ & $<.004$ & $<.022$ & $<.011$ & .01 & $<.004$ & $<.025$ \\
\hline$\stackrel{09}{0 . \cdots}$ & -- & -- & -- & -- & -- & -- & -- & -- & -- & -- & -- & -- & -- \\
\hline $\begin{array}{l}13 \ldots \\
\text { JUN }\end{array}$ & -- & -- & -- & -- & -- & -- & -- & -- & -- & -- & -- & -- & -- \\
\hline$\underset{\text { JUL }}{02} \cdots$ & $<.015$ & $<.006$ & $<.006$ & $<.003$ & $<.007$ & $<.003$ & $<.010$ & $<.004$ & $<.022$ & $<.011$ & .03 & $<.004$ & $<.025$ \\
\hline$\stackrel{13}{13} \cdots$ & -- & -- & -- & -- & -- & -- & -- & -- & -- & -- & -- & -- & -- \\
\hline $24 \ldots$ & $<.015$ & $<.006$ & $<.006$ & $<.003$ & $<.007$ & $<.003$ & $<.010$ & $<.004$ & $<.022$ & $<.011$ & .01 & $<.004$ & $<.025$ \\
\hline
\end{tabular}


Appendix 1. Periodically collected water-quality properties and constituents at six sites in Mustang Bayou near Houston, Texas, September 2004-August 2005-Continued.

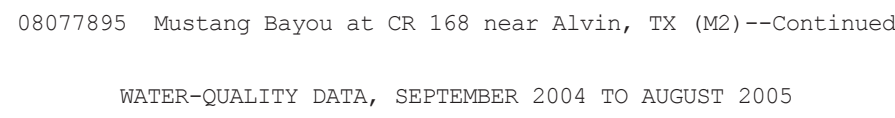

\begin{tabular}{|c|c|c|c|c|c|c|c|c|c|}
\hline & & & & & & & & & \\
\hline $\begin{array}{c}13 \ldots \\
\text { NOV }\end{array}$ & $<.011$ & $<.02$ & $<.010$ & .06 & $<.034$ & $<.02$ & $<.010$ & $<.002$ & $<.009$ \\
\hline $\begin{array}{l}08 \ldots \\
\text { JAN }\end{array}$ & -- & -- & -- & -- & -- & -- & -- & -- & -- \\
\hline$\underset{M A R}{06 \ldots}$ & $<.011$ & $<.02$ & $<.005$ & .08 & $<.034$ & $<.02$ & $<.010$ & $<.006$ & $<.009$ \\
\hline$\underset{A P R}{09} \cdots$ & -- & -- & -- & -- & -- & -- & -- & -- & -- \\
\hline$\stackrel{13}{13} \ldots$ & -- & -- & -- & -- & -- & -- & -- & -- & -- \\
\hline$\underset{\text { JUL }}{02} \cdots$ & $<.011$ & $<.02$ & .013 & .06 & $<.034 \mathrm{mc}$ & $<.02$ & $<.010$ & $<.006$ & $<.009$ \\
\hline$\underset{A U G}{13} \cdots$ & -- & -- & -- & -- & $1034 \mathrm{ma}$ & -- & -- & -- & \\
\hline $24 \ldots$ & $<.011$ & $<.02$ & $<.005$ & .04 & $<.034 m \mathrm{c}$ & $<.02$ & $<.010$ & $<.006$ & $<.009$ \\
\hline
\end{tabular}


Appendix 1. Periodically collected water-quality properties and constituents at six sites in Mustang Bayou near Houston, Texas, September 2004-August 2005-Continued.

08077890 Mustang Bayou at East South Street at Alvin, TX (M3)

WATER-QUALITY DATA， SEPTEMBER 2004 TO AUGUST 2005

\begin{tabular}{|c|c|c|c|c|c|c|c|c|c|c|c|c|c|}
\hline Date & Time & $\begin{array}{c}\text { Instan- } \\
\text { taneous } \\
\text { dis- } \\
\text { charge, } \\
\text { cfs }\end{array}$ & $\begin{array}{l}\text { Stream- } \\
\text { flow } \\
\text { sever- } \\
\text { ity, } \\
\text { code }\end{array}$ & $\begin{array}{l}\text { Sam- } \\
\text { pling } \\
\text { depth, } \\
\text { meters }\end{array}$ & $\begin{array}{c}\text { Temper- } \\
\text { ature, } \\
\text { water, } \\
\text { deg C }\end{array}$ & $\begin{array}{c}\text { Temper- } \\
\text { ature, } \\
\text { air, } \\
\operatorname{deg} \text { C }\end{array}$ & $\begin{array}{l}\text { Baro- } \\
\text { metric } \\
\text { pres- } \\
\text { sure, } \\
\text { mm Hg }\end{array}$ & $\begin{array}{c}\text { Dis- } \\
\text { solved } \\
\text { oxygen, } \\
\text { mg/L }\end{array}$ & $\begin{array}{l}\text { Dis- } \\
\text { solved } \\
\text { oxygen, } \\
\text { percent } \\
\text { of sat- } \\
\text { uration }\end{array}$ & $\begin{array}{c}\text { Specif. } \\
\text { conduc- } \\
\text { tance, } \\
\text { wat unf } \\
\text { uS/cm } \\
25 \text { degC }\end{array}$ & $\begin{array}{c}\text { pH, } \\
\text { water, } \\
\text { unfltrd } \\
\text { field, } \\
\text { std } \\
\text { units }\end{array}$ & $\begin{array}{l}\text { Alka- } \\
\text { linity, } \\
\text { wat flt } \\
\text { inc tit } \\
\text { field, } \\
\mathrm{mg} / \mathrm{L} \text { as } \\
\mathrm{CaCO} 3\end{array}$ & $\begin{array}{c}\text { Carbon- } \\
\text { ate, } \\
\text { wat flt } \\
\text { incrm. } \\
\text { titr.' } \\
\text { field, } \\
\text { mg/L }\end{array}$ \\
\hline $\begin{array}{l}\text { SEP } \\
13 \ldots \\
\text { NOV }\end{array}$ & 1053 & 6.97 & 3 & .30 & 28.5 & 31.0 & 763 & 3.9 & 51 & 423 & 7.4 & 124 & $<1$ \\
\hline$\underset{\text { JAN }}{08} \cdots$ & 1105 & 18.6 & 3 & .12 & 19.9 & 25.0 & 770 & 7.7 & 84 & 395 & 7.5 & -- & -- \\
\hline$\underset{M A R}{06 \ldots}$ & 1010 & 9.48 & 3 & .30 & 17.1 & 9.5 & 763 & 9.0 & 94 & 1290 & 7.8 & 235 & $<1$ \\
\hline$\underset{A P R}{09} \ldots$ & 1050 & 99.4 & 3 & .30 & 18.2 & 20.0 & 763 & 7.6 & 80 & 445 & 7.5 & 96 & $<1$ \\
\hline$\frac{13}{\text { JUN }}$ & 1030 & 15.1 & 2 & .11 & 22.6 & 25.5 & 762 & 8.7 & 101 & 1,110 & 7.8 & 230 & 1 \\
\hline$\underset{\text { JUL }}{02 \ldots}$ & 1120 & 5.83 & 2 & .21 & 28.2 & 29.0 & 759 & 9.0 & 116 & 703 & 7.6 & 184 & $<1$ \\
\hline$\underset{\text { AUG }}{13} \ldots$ & 1100 & 6.01 & 2 & .15 & 30.5 & 32.5 & 767 & 8.1 & 108 & 586 & 7.5 & 162 & 1 \\
\hline $24 \ldots$ & 0950 & 9.55 & 3 & .30 & 30.8 & 32.0 & 762 & 3.5 & 48 & 520 & 7.6 & 183 & $<1$ \\
\hline Date & $\begin{array}{c}\text { Bicar- } \\
\text { bonate, } \\
\text { wat flt } \\
\text { incrm. } \\
\text { titr., } \\
\text { field, } \\
\text { mg/L }\end{array}$ & $\begin{array}{l}\text { Color, } \\
\text { water, } \\
\text { fltrd, } \\
\text { Pt-Co } \\
\text { units }\end{array}$ & $\begin{array}{c}\text { Turbidity } \\
\text { white } \\
\text { light, } \\
\text { det ang } \\
90+/-30 \\
\text { corrctd } \\
\text { NTRU }\end{array}$ & $\begin{array}{l}\text { Sus- } \\
\text { pended } \\
\text { sedi- } \\
\text { ment } \\
\text { concen- } \\
\text { tration } \\
\text { mg/L }\end{array}$ & $\begin{array}{c}\text { Ammonia } \\
\text { water, } \\
\text { unfltrd } \\
\text { mg/L } \\
\text { as N }\end{array}$ & $\begin{array}{c}\text { BOD, } \\
\text { water, } \\
\text { unfltrd } \\
5 \text { day, } \\
20 \text { degC } \\
\text { mg/L }\end{array}$ & $\begin{array}{c}\text { CBOD, } \\
\text { water, } \\
\text { unfltrd } \\
5 \text { day, } \\
\text { mg/L }\end{array}$ & $\begin{array}{c}\text { E coli, } \\
\text { m-TEC } \\
\text { MF, } \\
\text { water, } \\
\text { col/ } \\
100 \mathrm{~mL}\end{array}$ & $\begin{array}{c}\text { Nitrite } \\
+ \\
\text { nitrate } \\
\text { water } \\
\text { fltrd, } \\
\text { mg/L } \\
\text { as N }\end{array}$ & $\begin{array}{c}\text { Nitrate } \\
\text { water, } \\
\text { fltrd, } \\
\text { mg/L } \\
\text { as N }\end{array}$ & $\begin{array}{c}\text { Nitrite } \\
\text { water, } \\
\text { fltrd, } \\
\text { mg/L } \\
\text { as N }\end{array}$ & $\begin{array}{l}\text { Total } \\
\text { nitro- } \\
\text { gen, } \\
\text { water, } \\
\text { unfltrd } \\
\text { mg/L }\end{array}$ & $\begin{array}{c}\text { Phos- } \\
\text { phorus, } \\
\text { water, } \\
\text { unfltrd } \\
\mathrm{mg} / \mathrm{L}\end{array}$ \\
\hline $\begin{array}{l}\text { SEP } \\
13 . .\end{array}$ & 150 & -- & & 16 & 07 & 36 & & 3.100 & 0996 & 09 & ( & 62 & 14 \\
\hline $\begin{array}{l}\text { NOV } \\
08 \ldots \\
\text { JAN }\end{array}$ & -- & $50 d$ & 39 & 44 & .05 & 2.0 & $1.7 \mathrm{w}$ & 130 & .094 & .09 & .008 & .62 & $\begin{array}{l}.14 \\
.13\end{array}$ \\
\hline $\begin{array}{c}06 \ldots \\
\text { MAR }\end{array}$ & 285 & 12 & 3.5 & 59 & .03 & 1.6 & 1.5 & 720 & .024 & .02 & .002 & .27 & E.02n \\
\hline $\begin{array}{l}09 \\
\operatorname{APR}\end{array}$ & 116 & $175 d$ & 110 & 126 & .09 & 3.0 & 3.4 & 1,600 & .107 & .10 & .012 & 1.5 & .22 \\
\hline $\begin{array}{l}13 \\
\text { JUN }\end{array}$ & 278 & 15 & 2.4 & 102 & .03 & .9 & .5 & 530 & $<.016$ & -- & .002 & -- & $<.04$ \\
\hline${ }_{\text {JUL }}^{02} \ldots$ & 223 & $30 d$ & 5.4 & 18 & .05 & 1.2 & 1.0 & E760k & .018 & .01 & .003 & .41 & .10 \\
\hline$\underset{\text { AUG }}{13} \cdots$ & 196 & 15 & $<2.0$ & 6 & E.04n & 1.4 & 1.4 & 3,500 & .018 & .01 & .004 & .50 & .10 \\
\hline $24 \ldots$ & 221 & 25 & 8.8 & 14 & .09 & 1.9 & 1.9 & 2,300 & .031 & .03 & .003 & .44 & .09 \\
\hline Date & $\begin{array}{l}\text { Ortho- } \\
\text { phos- } \\
\text { phate, } \\
\text { water, } \\
\text { fltrd, } \\
\text { mg/L } \\
\text { as P }\end{array}$ & $\begin{array}{c}\text { Ammonia } \\
+ \\
\text { org-N, } \\
\text { water, } \\
\text { unfltrd } \\
\text { mg/L } \\
\text { as N }\end{array}$ & $\begin{array}{l}\text { Organic } \\
\text { nitro- } \\
\text { gen, } \\
\text { water, } \\
\text { unfltrd } \\
\text { mg/L }\end{array}$ & $\begin{array}{c}\text { Chloro- } \\
\text { phyll a } \\
\text { phyto- } \\
\text { plank- } \\
\text { ton, } \\
\text { fluoro } \\
\text { ug/L }\end{array}$ & $\begin{array}{l}\text { Pheo- } \\
\text { phytin } \\
\text { a, } \\
\text { phyto- } \\
\text { plank- } \\
\text { ton } \\
\text { ug/L }\end{array}$ & $\begin{array}{l}\text { Chlor- } \\
\text { ide, } \\
\text { water, } \\
\text { fltrd } \\
\text { mg/L }\end{array}$ & $\begin{array}{c}\text { Sulfate } \\
\text { water, } \\
\text { fltrd } \\
\text { mg/L }\end{array}$ & $\begin{array}{l}\text { Solids, } \\
\text { total, } \\
\text { sus- } \\
\text { pended } \\
\text { mg/L }\end{array}$ & $\begin{array}{l}\text { Solids, } \\
\text { dis- } \\
\text { solved, } \\
\text { fltrd } \\
\text { mg/L }\end{array}$ & $\begin{array}{l}\text { alpha- } \\
\text { HCH, } \\
\text { water, } \\
\text { fltrd } \\
\text { ug/L }\end{array}$ & $\begin{array}{c}2,6-\mathrm{Di}- \\
\text { ethyl- } \\
\text { aniline } \\
\text { water } \\
\text { fltrd } \\
\text { ug/L }\end{array}$ & $\begin{array}{c}\text { Aceto- } \\
\text { chlor, } \\
\text { water, } \\
\text { fltrd } \\
\text { ug/L }\end{array}$ & $\begin{array}{c}\text { Ala- } \\
\text { chlor, } \\
\text { water, } \\
\text { fltrd } \\
\text { ug/L }\end{array}$ \\
\hline SEP & & & & & & & & & & & & & \\
\hline$\stackrel{13}{13} \ldots$ & $.080 \mathrm{c}$ & .53 & .46 & 1.6 & 1.4 & 39.0 & 15.0 & -- & 243 & $<.005$ & $<.006$ & $<.006$ & $<.005$ \\
\hline $\begin{array}{l}08 \\
\text { JAN }\end{array}$ & .066 & .56 & .51 & .8 & 1.4 & 37.8 & 12.4 & 24 & 223 & -- & -- & -- & -- \\
\hline$\stackrel{06 \ldots}{\operatorname{MAR}}$ & .016 & .24 & .21 & 2.8 & 1.1 & 249 & 27.2 & $<10$ & 690 & $<.005$ & $<.006$ & $<.006$ & $<.005$ \\
\hline$\underset{A P R}{09 \ldots}$ & .058 & 1.4 & 1.3 & .9 & 2.6 & 70.6 & 9.0 & 113 & 274 & -- & -- & -- & -- \\
\hline${ }_{\text {JUN }}^{13} \cdots$ & .017 & .21 & .19 & .4 & .4 & 194 & 25.7 & $<10$ & 599 & -- & -- & -- & -- \\
\hline${ }_{\text {JUL }}^{02} \cdots$ & .057 & .39 & .34 & 2.6 & 1.2 & 83.7 & 23.0 & $<10$ & 385 & $<.005$ & $<.006$ & $<.006$ & $<.005$ \\
\hline$\underset{A U G}{13} \ldots$ & .042 & .48 & -- & 2.8 & 1.2 & 69.9 & 22.8 & $<10$ & 330 & -- & -- & -- & -- \\
\hline $24 \ldots$ & .055 & .41 & .33 & 1.6 & 1.6 & 52.4 & 16.7 & $<10$ & 292 & $<.005$ & $<.006$ & $<.006$ & $<.005$ \\
\hline
\end{tabular}




\section{Water-Quality, Sediment-Quality, Stream-Habitat, and Biological Data for Mustang Bayou, Texas, 2004-05}

Appendix 1. Periodically collected water-quality properties and constituents at six sites in Mustang Bayou near Houston, Texas, September 2004-August 2005-Continued.

08077890 Mustang Bayou at East South Street at Alvin, TX (M3)--Continued WATER-QUALITY DATA, SEPTEMBER 2004 TO AUGUST 2005

\begin{tabular}{|c|c|c|c|c|c|c|c|c|c|c|c|c|c|}
\hline Date & $\begin{array}{l}\text { Atra- } \\
\text { zine, } \\
\text { water, } \\
\text { fltrd } \\
\text { ug/L }\end{array}$ & $\begin{array}{c}\text { CIAT, } \\
\text { water, } \\
\text { fltrd } \\
\text { ug/L }\end{array}$ & $\begin{array}{l}\text { Azin- } \\
\text { phos-, } \\
\text { methyl, } \\
\text { water, } \\
\text { fltrd } \\
\text { ug/L }\end{array}$ & $\begin{array}{l}\text { Ben- } \\
\text { flur- } \\
\text { alin, } \\
\text { water, } \\
\text { fltrd } \\
\text { ug/L }\end{array}$ & $\begin{array}{l}\text { Butyl- } \\
\text { ate, } \\
\text { water, } \\
\text { fltrd } \\
\text { ug/L }\end{array}$ & $\begin{array}{l}\text { Car- } \\
\text { baryl, } \\
\text { water, } \\
\text { fltrd } \\
\text { ug/L }\end{array}$ & $\begin{array}{l}\text { Carbo- } \\
\text { furan, } \\
\text { water, } \\
\text { fltrd } \\
\text { ug/L }\end{array}$ & $\begin{array}{l}\text { Chlor- } \\
\text { pyrifos, } \\
\text { water, } \\
\text { fltrd } \\
\text { ug/L }\end{array}$ & $\begin{array}{l}\text { Cis- } \\
\text { Per- } \\
\text { methrin, } \\
\text { water, } \\
\text { fltrd } \\
\text { ug/L }\end{array}$ & $\begin{array}{c}\text { Cyana- } \\
\text { zine, } \\
\text { water, } \\
\text { fltrd } \\
\text { ug/L }\end{array}$ & $\begin{array}{c}\text { DCPA, } \\
\text { water, } \\
\text { fltrd } \\
\text { ug/L }\end{array}$ & $\begin{array}{c}\text { Diazi- } \\
\text { non, } \\
\text { water, } \\
\text { fltrd } \\
\text { ug/L }\end{array}$ & $\begin{array}{l}\text { Diel- } \\
\text { drin, } \\
\text { water, } \\
\text { fltrd } \\
\text { ug/L }\end{array}$ \\
\hline \multicolumn{14}{|l|}{ SEP } \\
\hline $\begin{array}{c}13 \ldots \\
\text { NOV }\end{array}$ & .050 & E.006 & E.119 & $<.010$ & $<.004$ & $<.041$ & $<.020$ & $<.005$ & $<.006$ & $<.018$ & $<.003$ & .775 & $<.009$ \\
\hline$\underset{\text { JAN }}{08} \ldots$ & -- & -- & -- & -- & -- & -- & -- & -- & -- & -- & -- & -- & -- \\
\hline $\begin{array}{c}06 \ldots \\
\text { MAR }\end{array}$ & .086 & $<.006$ & $<.050$ & $<.010$ & $<.004$ & $<.041$ & $<.020$ & $<.010$ & $<.006$ & $<.018$ & $<.003$ & $<.010$ & $<.009$ \\
\hline $\begin{array}{l}09 \ldots \\
\mathrm{APR}\end{array}$ & -- & -- & -- & -- & -- & -- & -- & -- & -- & -- & -- & -- & -- \\
\hline$\underset{\text { JUN }}{13} \ldots$ & -- & -- & -- & -- & -- & -- & -- & -- & -- & -- & -- & -- & -- \\
\hline$\underset{\text { JUL }}{02 \ldots}$ & $.072 \mathrm{E}$ & $\mathrm{E} .024 \mathrm{mc} \quad \mathrm{E}$ & E. $082 \mathrm{mc}$ & $<.010$ & $<.004$ & $<.041 \mathrm{mc}$ & $<.020 \mathrm{mc}$ & $<.005$ & $<.006$ & $<.018$ & $<.003$ & $<.005$ & $<.009$ \\
\hline$\stackrel{13}{13} \ldots$ & -- & -- & -- & -- & -- & -- & -- & -- & -- & -- & -- & -- & -- \\
\hline $24 \ldots$ & $.144 \quad \mathrm{E}$ & $\mathrm{E} .007 \mathrm{mc}$ & $<.050 \mathrm{mc}$ & $<.010$ & $<.004$ & $<.041 \mathrm{mc}$ & $<.020 \mathrm{mc}$ & $<.005$ & $<.006$ & $<.018$ & $<.003$ & $<.005$ & $<.009$ \\
\hline Date & $\begin{array}{l}\text { Disul- } \\
\text { foton, } \\
\text { water, } \\
\text { fltrd } \\
\text { ug/L }\end{array}$ & $\begin{array}{l}\text { EPTC, } \\
\text { water, } \\
\text { fltrd } \\
\text { ug/L }\end{array}$ & $\begin{array}{l}\text { Ethal- } \\
\text { flur- } \\
\text { alin, } \\
\text { water, } \\
\text { fltrd } \\
\text { ug/L }\end{array}$ & $\begin{array}{l}\text { Etho- } \\
\text { prop, } \\
\text { water, } \\
\text { fltrd } \\
\text { ug/L }\end{array}$ & $\begin{array}{l}\text { Desulf- } \\
\text { inyl- } \\
\text { fipro- } \\
\text { nil, } \\
\text { amide, } \\
\text { wat flt } \\
\text { ug/L }\end{array}$ & $\begin{array}{l}\text { Fipro- } \\
\text { nil } \\
\text { sulfide } \\
\text { water, } \\
\text { fltrd } \\
\text { ug/L }\end{array}$ & $\begin{array}{l}\text { Fipro- } \\
\text { nil } \\
\text { sulfone, } \\
\text { water, } \\
\text { fltrd } \\
\text { ug/L }\end{array}$ & $\begin{array}{l}\text { Desulf- } \\
\text { inyl } \\
\text { fipro- } \\
\text { nil, } \\
\text { water, } \\
\text { fltrd } \\
\text { ug/L }\end{array}$ & $\begin{array}{l}\text { Fipro- } \\
\text { nil, } \\
\text { water, } \\
\text { fltrd } \\
\text { ug/L }\end{array}$ & $\begin{array}{c}\text { Fonofos, } \\
\text { water, } \\
\text { fltrd } \\
\text { ug/L }\end{array}$ & $\begin{array}{l}\text { Lindane, } \\
\text { water, } \\
\text { fltrd } \\
\text { ug/L }\end{array}$ & $\begin{array}{l}\text { Linuron, } \\
\text { water, } \\
\text { fltrd } \\
\text { ug/L }\end{array}$ & $\begin{array}{l}\text { Mala- } \\
\text { thion, } \\
\text { water, } \\
\text { fltrd } \\
\text { ug/L }\end{array}$ \\
\hline \multicolumn{14}{|l|}{ SEP } \\
\hline$\stackrel{13}{\text { NOV }}$ & $<.02$ & $<.004$ & $<.009$ & $<.005$ & $<.029$ & E.003t & E.003t & E.003t & E.008n & $<.003$ & $<.004$ & $<.035$ & .091 \\
\hline$\underset{\text { JAN }}{08} \cdots$ & -- & -- & -- & -- & -- & -- & -- & -- & -- & -- & -- & -- & -- \\
\hline$\underset{\text { MAR }}{06 \ldots}$ & $<.02$ & $<.004$ & $<.009$ & $<.005$ & $<.029$ & $<.013$ & $<.024$ & $<.012$ & $<.016$ & $<.003$ & $<.004$ & $<.035$ & $<.027$ \\
\hline$\underset{A P R}{09 \cdots}$ & -- & -- & -- & -- & -- & -- & -- & -- & -- & -- & -- & -- & -- \\
\hline${ }_{\text {JUN }}^{13} \cdots$ & -- & -- & -- & -- & -- & -- & -- & -- & -- & -- & -- & -- & -- \\
\hline$\underset{\text { JUL }}{02 \ldots}$ & $<.02$ & $<.004$ & $<.009$ & $<.005$ & E.003mtc & c $\quad .075$ & .024 & E.011n & $\mathrm{E} .060 \mathrm{mc}$ & $=<.003$ & $<.004$ & $<.035$ & $<.027$ \\
\hline$\underset{\text { AUG }}{13} \ldots$ & -- & -- & -- & -- & -- & -- & -- & -- & -- & -- & -- & -- & -- \\
\hline $24 \ldots$ & $<.02 \mathrm{mc}$ & $<.004$ & $<.009$ & $<.005$ & $<.029 \mathrm{mc}$ & $<.013$ & $<.024$ & $<.012$ & $<.016 \mathrm{mc}$ & $=<.003$ & $<.004$ & $<.035$ & $<.027$ \\
\hline Date & $\begin{array}{l}\text { Methyl } \\
\text { para- } \\
\text { thion, } \\
\text { water, } \\
\text { fltrd, } \\
\text { ug/L }\end{array}$ & $\begin{array}{l}\text { Metola- } \\
\text { chlor, } \\
\text { water, } \\
\text { fltrd, } \\
\text { ug/L }\end{array}$ & $\begin{array}{l}\text { Metri- } \\
\text { buzin, } \\
\text { water, } \\
\text { fltrd, } \\
\text { ug/L }\end{array}$ & $\begin{array}{l}\text { Moli- } \\
\text { nate, } \\
\text { water, } \\
\text { fltrd, } \\
\text { ug/L }\end{array}$ & $\begin{array}{l}\text { Naprop- } \\
\text { amide, } \\
\text { water, } \\
\text { fltrd, } \\
\text { ug/L }\end{array}$ & $\begin{array}{l}\mathrm{p}, \mathrm{p}^{\prime}- \\
\text { DDE, } \\
\text { water, } \\
\text { fltrd, } \\
\text { ug/L }\end{array}$ & $\begin{array}{l}\text { Para- } \\
\text { thion, } \\
\text { water, } \\
\text { fltrd, } \\
\text { ug/L }\end{array}$ & $\begin{array}{l}\text { Peb- } \\
\text { ulate, } \\
\text { water, } \\
\text { fltrd, } \\
\text { ug/L }\end{array}$ & $\begin{array}{l}\text { Pendi- } \\
\text { meth- } \\
\text { alin, } \\
\text { water, } \\
\text { fltrd, } \\
\text { ug/L }\end{array}$ & $\begin{array}{c}\text { Phorate, } \\
\text { water, } \\
\text { fltrd, } \\
\text { ug/L }\end{array}$ & $\begin{array}{c}\text { Prome- } \\
\text { ton, } \\
\text { water, } \\
\text { fltrd, } \\
\text { ug/L }\end{array}$ & $\begin{array}{l}\text { Propy- } \\
\text { zamide, } \\
\text { water, } \\
\text { fltrd, } \\
\text { ug/L }\end{array}$ & $\begin{array}{l}\text { Propa- } \\
\text { chlor, } \\
\text { water } \\
\text { fltrd, } \\
\text { ug/L }\end{array}$ \\
\hline SEP & & & & & & & & & & & & & \\
\hline $\begin{array}{c}13 \ldots \\
\text { NOV }\end{array}$ & $<.015$ & $<.013$ & $<.006$ & $<.003$ & $<.007$ & $<.003$ & $<.010$ & $<.004$ & $<.022$ & $<.011$ & .01 & $<.004$ & $<.025$ \\
\hline$\underset{\text { JAN }}{08} \cdots$ & -- & -- & -- & -- & -- & -- & -- & -- & -- & -- & -- & -- & -- \\
\hline$\stackrel{06 \ldots}{M A R}$ & $<.015$ & $<.006$ & $<.006$ & $<.003$ & $<.007$ & $<.005$ & $<.010$ & $<.004$ & $<.022$ & $<.011$ & $<.01$ & $<.004$ & $<.025$ \\
\hline$\underset{A P R}{09} \cdots$ & -- & -- & -- & -- & -- & -- & -- & -- & -- & -- & -- & -- & -- \\
\hline$\underset{\text { JUN }}{13} \ldots$ & -- & -- & -- & -- & -- & -- & -- & -- & -- & -- & -- & -- & -- \\
\hline$\underset{\text { JUL }}{02 \ldots}$ & $<.015$ & $<.006$ & $<.006$ & $<.003$ & $<.007$ & $<.003$ & $<.010$ & $<.004$ & $<.022$ & $<.011$ & .02 & $<.004$ & $<.025$ \\
\hline${ }_{A U G}^{13} \ldots$ & -- & -- & -- & -- & -- & -- & -- & -- & -- & -- & -- & -- & -- \\
\hline $24 \ldots$ & $<.015$ & $<.006$ & $<.006$ & $<.003$ & $<.007$ & $<.003$ & $<.010$ & $<.004$ & $<.022$ & $<.011$ & $<.01$ & $<.004$ & $<.025$ \\
\hline
\end{tabular}


Appendix 1. Periodically collected water-quality properties and constituents at six sites in Mustang Bayou near Houston, Texas, September 2004-August 2005-Continued.

08077890 Mustang Bayou at East South Street at Alvin, TX (M3)--Continued

WATER-QUALITY DATA, SEPTEMBER 2004 TO AUGUST 2005

\begin{tabular}{|c|c|c|c|c|c|c|c|c|c|}
\hline Date & $\begin{array}{c}\text { Pro- } \\
\text { panil, } \\
\text { water, } \\
\text { fltrd } \\
\text { ug/L }\end{array}$ & $\begin{array}{l}\text { Propar- } \\
\text { gite, } \\
\text { water, } \\
\text { fltrd } \\
\text { ug/L }\end{array}$ & $\begin{array}{l}\text { Sima- } \\
\text { zine, } \\
\text { water, } \\
\text { fltrd } \\
\text { ug/L }\end{array}$ & $\begin{array}{c}\text { Tebu- } \\
\text { thiuron, } \\
\text { water, } \\
\text { fltrd } \\
\text { ug/L }\end{array}$ & $\begin{array}{c}\text { Terbu- } \\
\text { cil, } \\
\text { water, } \\
\text { fltrd } \\
\text { ug/L }\end{array}$ & $\begin{array}{l}\text { Terbu- } \\
\text { fos, } \\
\text { water, } \\
\text { fltrd } \\
\text { ug/L }\end{array}$ & $\begin{array}{c}\text { Thio- } \\
\text { bencarb, } \\
\text { water, } \\
\text { fltrd } \\
\text { ug/L }\end{array}$ & $\begin{array}{l}\text { Tri- } \\
\text { allate, } \\
\text { water, } \\
\text { fltrd } \\
\text { ug/L }\end{array}$ & $\begin{array}{l}\text { Tri- } \\
\text { flur- } \\
\text { alin, } \\
\text { water, } \\
\text { fltrd } \\
\text { ug/L }\end{array}$ \\
\hline SEP & & & & & & & & & \\
\hline${ }_{\text {NOV }}^{13} \ldots$ & $<.011$ & $<.02$ & .016 & .07 & $<.034$ & $<.02$ & $<.010$ & $<.002$ & $<.009$ \\
\hline$\underset{\text { JAN }}{08 \ldots}$ & -- & -- & -- & -- & -- & -- & -- & -- & - \\
\hline $\begin{array}{c}06 \ldots \\
\text { MAR }\end{array}$ & $<.011$ & $<.02$ & $<.005$ & .09 & $<.034$ & $<.02$ & $<.010$ & $<.006$ & $<.009$ \\
\hline$\underset{A P R}{09} \cdots$ & -- & -- & -- & -- & -- & -- & -- & -- & - \\
\hline$\underset{\text { JUN }}{13 \ldots}$ & -- & -- & -- & -- & -- & -- & -- & -- & - \\
\hline${ }_{\text {JUL }} 02 \ldots$ & $<.011$ & $<.02$ & $<.010$ & .07 & $<.034 \mathrm{mc}$ & $<.02$ & $<.010$ & $<.006$ & $<.009$ \\
\hline$\underset{\mathrm{AUG}}{13} \cdots$ & -- & -- & -- & -- & -- & -- & -- & -- & \\
\hline $24 \ldots$ & $<.011$ & $<.02$ & $<.005$ & .05 & $<.034 \mathrm{mc}$ & $<.02$ & $<.010$ & $<.006$ & $<.009$ \\
\hline
\end{tabular}




\section{Water-Quality, Sediment-Quality, Stream-Habitat, and Biological Data for Mustang Bayou, Texas, 2004-05}

Appendix 1. Periodically collected water-quality properties and constituents at six sites in Mustang Bayou near Houston, Texas, September 2004-August 2005-Continued.

08077885 Mustang Bayou at CR 99 near Alvin, TX (M4)

WATER-QUALITY DATA， SEPTEMBER 2004 TO AUGUST 2005

\begin{tabular}{|c|c|c|c|c|c|c|c|c|c|c|c|c|c|}
\hline Date & Time & $\begin{array}{c}\text { Instan- } \\
\text { taneous } \\
\text { dis- } \\
\text { charge, } \\
\text { cfs }\end{array}$ & $\begin{array}{l}\text { Stream- } \\
\text { flow } \\
\text { sever- } \\
\text { ity, } \\
\text { code }\end{array}$ & $\begin{array}{l}\text { Sam- } \\
\text { pling } \\
\text { depth, } \\
\text { meters }\end{array}$ & $\begin{array}{c}\text { Temper- } \\
\text { ature, } \\
\text { water, } \\
\text { deg C }\end{array}$ & $\begin{array}{c}\text { Temper- } \\
\text { ature, } \\
\text { air, } \\
\text { deg C }\end{array}$ & $\begin{array}{l}\text { Baro- } \\
\text { metric } \\
\text { pres- } \\
\text { sure, } \\
\text { mm Hg }\end{array}$ & $\begin{array}{c}\text { Dis- } \\
\text { solved } \\
\text { oxygen, } \\
\text { mg/L }\end{array}$ & $\begin{array}{l}\text { Dis- } \\
\text { solved } \\
\text { oxygen, } \\
\text { percent } \\
\text { of sat- } \\
\text { uration }\end{array}$ & $\begin{array}{l}\text { Specif. } \\
\text { conduc- } \\
\text { tance, } \\
\text { wat unf } \\
\text { uS } / \mathrm{cm} \\
25 \text { degC }\end{array}$ & $\begin{array}{c}\text { pH, } \\
\text { water, } \\
\text { unfltrd } \\
\text { field, } \\
\text { std } \\
\text { units }\end{array}$ & $\begin{array}{l}\text { Alka- } \\
\text { linity, } \\
\text { wat flt } \\
\text { inc tit } \\
\text { field, } \\
\mathrm{mg} / \mathrm{L} \text { as } \\
\mathrm{CaCO3}\end{array}$ & $\begin{array}{c}\text { Carbon- } \\
\text { ate, } \\
\text { wat flt } \\
\text { incrm. } \\
\text { titr. } \\
\text { field, } \\
\text { mg/L }\end{array}$ \\
\hline $\begin{array}{c}\text { SEP } \\
13 \ldots \\
\text { NOV }\end{array}$ & 1000 & 5.78 & 3 & .30 & 28.2 & 28.0 & 761 & 6.1 & 79 & 654 & 7.5 & 196 & $<1$ \\
\hline$\underset{\text { JAN }}{08 \ldots}$ & 1025 & 17.2 & 3 & .30 & 19.3 & 24.5 & 768 & 6.7 & 72 & 381 & 7.3 & 111 & $<1$ \\
\hline $\begin{array}{l}04 \ldots \\
\text { MAR }\end{array}$ & 1255 & 7.53 & 3 & .12 & 21.9 & 23.5 & 765 & 7.0 & 80 & 1,570 & 8.0 & 207 & 1 \\
\hline$\underset{A P R}{09 \ldots}$ & 1005 & 63.6 & 3 & .30 & 17.6 & 18.5 & 762 & 6.6 & 69 & 445 & 7.4 & 83 & $<1$ \\
\hline $\begin{array}{l}13 \ldots \\
\text { JUN }\end{array}$ & 1115 & 7.65 & 2 & .12 & 22.5 & 25.5 & 762 & 11.5 & 133 & 1,920 & 8.1 & 222 & 1 \\
\hline$\underset{\text { JUL }}{02 \ldots}$ & 1030 & 3.72 & 3 & .16 & 27.8 & 28.0 & 759 & 7.7 & 99 & 759 & 7.6 & -- & -- \\
\hline$\underset{\text { AUG }}{13} \ldots$ & 1020 & 1.12 & 2 & .11 & 30.2 & 33.0 & 766 & 5.4 & 71 & 651 & 7.5 & 173 & $<1$ \\
\hline $24 \ldots$ & 1035 & 5.08 & 3 & .13 & 30.8 & 31.0 & 762 & 5.6 & 75 & 497 & 7.9 & 159 & $<1$ \\
\hline Date & $\begin{array}{c}\text { Bicar- } \\
\text { bonate, } \\
\text { wat flt } \\
\text { incrm. } \\
\text { titr., } \\
\text { field, } \\
\text { mg/L }\end{array}$ & $\begin{array}{l}\text { Color, } \\
\text { water, } \\
\text { fltrd, } \\
\text { Pt-Co } \\
\text { units }\end{array}$ & $\begin{array}{c}\text { Turbidity } \\
\text { white } \\
\text { light, } \\
\text { det ang } \\
90+/-30 \\
\text { corrctd } \\
\text { NTRU }\end{array}$ & $\begin{array}{l}\text { Sus- } \\
\text { pended } \\
\text { sedi- } \\
\text { ment } \\
\text { concen- } \\
\text { tration } \\
\text { mg/L }\end{array}$ & $\begin{array}{c}\text { Ammonia } \\
\text { water, } \\
\text { unfltrd } \\
\text { mg/L } \\
\text { as N }\end{array}$ & $\begin{array}{c}\text { BOD, } \\
\text { water, } \\
\text { unfltrd } \\
5 \text { day, } \\
20 \text { degc } \\
\text { mg/L }\end{array}$ & $\begin{array}{c}\text { CBOD, } \\
\text { water, } \\
\text { unfltrd } \\
5 \text { day, } \\
\text { mg/L }\end{array}$ & $\begin{array}{c}\text { E coli, } \\
\text { m-TEC } \\
\text { MF, } \\
\text { water, } \\
\text { col/ } \\
100 \mathrm{~mL}\end{array}$ & $\begin{array}{c}\text { Nitrite } \\
+ \\
\text { nitrate } \\
\text { water } \\
\text { fltrd, } \\
\text { mg/L } \\
\text { as N }\end{array}$ & $\begin{array}{c}\text { Nitrate } \\
\text { water, } \\
\text { fltrd, } \\
\text { mg/L } \\
\text { as N }\end{array}$ & $\begin{array}{c}\text { Nitrite } \\
\text { water, } \\
\text { fltrd, } \\
\text { mg/L } \\
\text { as N }\end{array}$ & $\begin{array}{l}\text { Total } \\
\text { nitro- } \\
\text { gen, } \\
\text { water, } \\
\text { unfltrd } \\
\text { mg/L }\end{array}$ & $\begin{array}{c}\text { Phos- } \\
\text { phorus, } \\
\text { water, } \\
\text { unfltrd } \\
\mathrm{mg} / \mathrm{L}\end{array}$ \\
\hline $\begin{array}{l}\text { SEP } \\
\quad 13 \ldots\end{array}$ & 237 & -- & -- & 7 & .01 & 1.2 & -- & 80 & $<.016 \mathrm{c}$ & -- & E.001n & -- & .08 \\
\hline $\begin{array}{l}\text { NOV } \\
08 \ldots \\
\text { JAN }\end{array}$ & 134 & $50 d$ & 70 & $--b$ & .05 & 2.1 & 1.7 & $58 \mathrm{k}$ & .103 & .09 & .010 & .69 & .13 \\
\hline$\underset{\text { MAR }}{04 \ldots}$ & 250 & 5 & 3.1 & 27 & .03 & 1.7 & 1.2 & E11k & E.008n & -- & E.001n & -- & $<.04$ \\
\hline$\underset{A P R}{09} \cdots$ & 100 & $250 d$ & 120 & 96 & .08 & 3.7 & 3.3 & 1,100 & .093 & .08 & .010 & 1.6 & .19 \\
\hline$\stackrel{13 \ldots}{\text { JUN }}$ & 268 & 15 & 6.6 & 27 & .04 & 1.0 & .5 & E90k & E.012n & -- & .003 & -- & E.03n \\
\hline $\begin{array}{l}02 \ldots \\
\text { JUL }\end{array}$ & -- & 25 & 4.6 & 11 & E.02n & .7 & .5 & E16k & $<.016$ & -- & $<.002$ & -- & .08 \\
\hline$\underset{\text { AUG }}{13} \ldots$ & 209 & 25 & 4.0 & 33 & E.04n & $\mathrm{E} 1.2$ & E. 9 & 500 & $<.016$ & -- & $\mathrm{E} .001 \mathrm{n}$ & -- & .12 \\
\hline $24 \ldots$ & 192 & 25 & 9.1 & 11 & E.02n & 1.7 & 1.7 & E37k & $<.016$ & -- & $<.002$ & -- & .08 \\
\hline Date & $\begin{array}{l}\text { Ortho- } \\
\text { phos- } \\
\text { phate, } \\
\text { water, } \\
\text { fltrd, } \\
\text { mg/L } \\
\text { as P }\end{array}$ & $\begin{array}{c}\text { Ammonia } \\
+ \\
\text { org-N, } \\
\text { water, } \\
\text { unfltrd } \\
\text { mg/L } \\
\text { as N }\end{array}$ & $\begin{array}{l}\text { Organic } \\
\text { nitro- } \\
\text { gen, } \\
\text { water, } \\
\text { unfltrd } \\
\text { mg/L }\end{array}$ & $\begin{array}{c}\text { Chloro- } \\
\text { phyll a } \\
\text { phyto- } \\
\text { plank- } \\
\text { ton, } \\
\text { fluoro } \\
\text { ug/L }\end{array}$ & $\begin{array}{l}\text { Pheo- } \\
\text { phytin } \\
\text { a, } \\
\text { phyto- } \\
\text { plank- } \\
\text { ton } \\
\text { ug/L }\end{array}$ & $\begin{array}{l}\text { Chlor- } \\
\text { ide, } \\
\text { water, } \\
\text { fltrd } \\
\text { mg/L }\end{array}$ & $\begin{array}{c}\text { Sulfate } \\
\text { water, } \\
\text { fltrd } \\
\text { mg/L }\end{array}$ & $\begin{array}{l}\text { Solids, } \\
\text { total, } \\
\text { sus- } \\
\text { pended } \\
\text { mg/L }\end{array}$ & $\begin{array}{l}\text { Solids, } \\
\text { dis- } \\
\text { solved, } \\
\text { fltrd } \\
\mathrm{mg} / \mathrm{L}\end{array}$ & $\begin{array}{c}\text { alpha- } \\
\text { HCH, } \\
\text { water, } \\
\text { fltrd } \\
\text { ug/L }\end{array}$ & $\begin{array}{c}2,6-D i- \\
\text { ethyl- } \\
\text { aniline } \\
\text { water } \\
\text { fltrd } \\
\text { ug/L }\end{array}$ & $\begin{array}{l}\text { Aceto- } \\
\text { chlor, } \\
\text { water, } \\
\text { fltrd } \\
\text { ug/L }\end{array}$ & $\begin{array}{c}\text { Ala- } \\
\text { chlor, } \\
\text { water, } \\
\text { fltrd } \\
\text { ug/L }\end{array}$ \\
\hline SEP & & & & & & & & & & & & & \\
\hline$\underset{\text { NOV }}{13 \ldots}$ & $.063 c$ & .24 & .23 & .7 & .7 & 66.8 & 22.6 & -- & 378 & $<.005$ & $<.006$ & $<.006$ & $<.005$ \\
\hline$\underset{\text { JAN }}{08} \ldots$ & .063 & .59 & .54 & 1.5 & 2.1 & 33.3 & 11.7 & 52 & 219 & -- & -- & -- & -- \\
\hline$\underset{\text { MAR }}{04 \ldots}$ & .017 & .26 & .23 & 1.9 & 1.0 & $344 d$ & 25.1 & $<10$ & 861 & $<.005$ & $<.006$ & $<.006$ & $<.005$ \\
\hline $\begin{array}{c}09 . \cdots \\
\text { APR }\end{array}$ & .036 & 1.5 & 1.4 & 1.9 & 4.2 & 78.2 & 7.1 & 100 & 264 & -- & -- & -- & -- \\
\hline$\underset{\text { JUN }}{13 \ldots}$ & .013 & .27 & .23 & .7 & .6 & $454 d$ & $23.5 d$ & $<10$ & 1050 & -- & -- & -- & -- \\
\hline$\underset{\text { JUL }}{02 \ldots}$ & .054 & .27 & -- & 1.1 & 1.2 & 104 & 19.6 & $<10$ & 425 & $<.005$ & $<.006$ & $<.006$ & $<.005$ \\
\hline$\underset{\text { AUG }}{13 \ldots}$ & .063 & .48 & -- & 2.8 & 2.7 & 86.6 & 20.8 & $<10$ & 364 & -- & -- & -- & -- \\
\hline $24 \ldots$ & .055 & .41 & -- & .8 & 1.1 & 57.5 & 14.4 & $<10$ & 281 & $<.005$ & $<.006$ & $<.006$ & $<.005$ \\
\hline
\end{tabular}


Appendix 1. Periodically collected water-quality properties and constituents at six sites in Mustang Bayou near Houston, Texas, September 2004-August 2005-Continued.

08077885 Mustang Bayou at CR 99 near Alvin, TX (M4)--Continued WATER-QUALITY DATA, SEPTEMBER 2004 TO AUGUST 2005

\begin{tabular}{|c|c|c|c|c|c|c|c|c|c|c|c|c|c|}
\hline Date & $\begin{array}{l}\text { Atra- } \\
\text { zine, } \\
\text { water, } \\
\text { fltrd } \\
\text { ug/L }\end{array}$ & $\begin{array}{l}\text { CIAT, } \\
\text { water, } \\
\text { fltrd } \\
\text { ug/L }\end{array}$ & $\begin{array}{l}\text { Azin- } \\
\text { phos-, } \\
\text { methyl, } \\
\text { water, } \\
\text { fltrd } \\
\text { ug/L }\end{array}$ & $\begin{array}{c}\text { Ben- } \\
\text { flur- } \\
\text { alin, } \\
\text { water, } \\
\text { fltrd } \\
\text { ug/L }\end{array}$ & $\begin{array}{l}\text { Butyl- } \\
\text { ate, } \\
\text { water, } \\
\text { fltrd } \\
\text { ug/L }\end{array}$ & $\begin{array}{c}\text { Car- } \\
\text { baryl, } \\
\text { water, } \\
\text { fltrd } \\
\text { ug/L }\end{array}$ & $\begin{array}{l}\text { Carbo- } \\
\text { furan, } \\
\text { water, } \\
\text { fltrd } \\
\text { ug/L }\end{array}$ & $\begin{array}{l}\text { Chlor- } \\
\text { pyrifos, } \\
\text { water, } \\
\text { fltrd } \\
\text { ug/L }\end{array}$ & $\begin{array}{c}\text { cis- } \\
\text { Per- } \\
\text { methrin, } \\
\text { water, } \\
\text { fltrd } \\
\text { ug/L }\end{array}$ & $\begin{array}{c}\text { Cyana- } \\
\text { zine, } \\
\text { water, } \\
\text { fltrd } \\
\text { ug/L }\end{array}$ & $\begin{array}{c}\text { DCPA, } \\
\text { water, } \\
\text { fltrd } \\
\text { ug/L }\end{array}$ & $\begin{array}{l}\text { Diazi- } \\
\text { non, } \\
\text { water, } \\
\text { fltrd } \\
\text { ug/L }\end{array}$ & $\begin{array}{l}\text { Diel- } \\
\text { drin, } \\
\text { water, } \\
\text { fltrd } \\
\text { ug/L }\end{array}$ \\
\hline SEP & & & & & & & & & & & & & \\
\hline $\begin{array}{c}13 \ldots \\
\text { NOV }\end{array}$ & .035 & E.007 & $<.050$ & $<.010$ & $<.004$ & $<.041$ & $<.020$ & $<.005$ & $<.006$ & $<.018$ & $<.003$ & $<.005$ & $<.009$ \\
\hline$\underset{\text { JAN }}{08} \cdots$ & -- & -- & -- & -- & -- & -- & -- & -- & -- & -- & -- & -- & -- \\
\hline$\underset{M A R}{04} \ldots$ & .115 & E.007 & $<.050$ & $<.010$ & $<.004$ & $<.041$ & $<.020$ & $<.005$ & $<.006$ & $<.018$ & $<.003$ & $<.005$ & $<.009$ \\
\hline $\begin{array}{c}09 \\
\mathrm{APR}\end{array}$ & -- & -- & -- & -- & -- & -- & -- & -- & -- & -- & -- & -- & -- \\
\hline$\underset{J U N}{13} \ldots$ & -- & -- & -- & -- & -- & -- & -- & -- & -- & -- & -- & -- & -- \\
\hline${ }_{\text {JUL }}^{02} \cdots$ & .149 & E. $025 \mathrm{mc}$ & E. $056 \mathrm{mc}$ & $<.010$ & $<.004$ & $<.041 \mathrm{mc}$ & $<.020 \mathrm{mc}$ & $<.005$ & $<.006$ & $<.018$ & $<.003$ & $<.005$ & $<.009$ \\
\hline${ }_{\text {AUG }}^{13} \ldots$ & -- & -- & -- & -- & -- & -- & -- & -- & -- & -- & -- & -- & -- \\
\hline $24 \ldots$ & .218 & E.010mc & $<.050 \mathrm{mc}$ & $<.010$ & $<.004$ & $<.041 \mathrm{mc}$ & $<.020 \mathrm{mc}$ & $<.005$ & $<.006$ & $<.018$ & $<.003$ & $<.005$ & $<.009$ \\
\hline Date & $\begin{array}{l}\text { Disul- } \\
\text { foton, } \\
\text { water, } \\
\text { fltrd } \\
\text { ug/L }\end{array}$ & $\begin{array}{l}\text { EPTC, } \\
\text { water, } \\
\text { fltrd } \\
\text { ug/L }\end{array}$ & $\begin{array}{l}\text { Ethal- } \\
\text { flur- } \\
\text { alin, } \\
\text { water, } \\
\text { fltrd } \\
\text { ug/L }\end{array}$ & $\begin{array}{l}\text { Etho- } \\
\text { prop, } \\
\text { water, } \\
\text { fltrd } \\
\text { ug/L }\end{array}$ & $\begin{array}{c}\text { Desulf- } \\
\text { inyl- } \\
\text { fipro- } \\
\text { nil, } \\
\text { amide, } \\
\text { wat flt } \\
\text { ug/L }\end{array}$ & $\begin{array}{l}\text { Fipro- } \\
\text { nil } \\
\text { sulfide } \\
\text { water, } \\
\text { fltrd } \\
\text { ug/L }\end{array}$ & $\begin{array}{l}\text { Fipro- } \\
\text { nil } \\
\text { sulfone, } \\
\text { water, } \\
\text { fltrd } \\
\text { ug/L }\end{array}$ & $\begin{array}{l}\text { Desulf- } \\
\text { inyl } \\
\text { fipro- } \\
\text { nil, } \\
\text { water, } \\
\text { fltrd } \\
\text { ug/L }\end{array}$ & $\begin{array}{l}\text { Fipro- } \\
\text { nil, } \\
\text { water, } \\
\text { fltrd } \\
\text { ug/L }\end{array}$ & $\begin{array}{c}\text { Fonofos, } \\
\text { water, } \\
\text { fltrd } \\
\text { ug/L }\end{array}$ & $\begin{array}{l}\text { Lindane, } \\
\text { water, } \\
\text { fltrd } \\
\text { ug/L }\end{array}$ & $\begin{array}{l}\text { Linuron, } \\
\text { water, } \\
\text { fltrd } \\
\text { ug/L }\end{array}$ & $\begin{array}{l}\text { Mala- } \\
\text { thion, } \\
\text { water, } \\
\text { fltrd } \\
\text { ug/L }\end{array}$ \\
\hline SEP & & & & & & & & & & & & & \\
\hline $\begin{array}{l}13 \ldots \\
\text { NOV }\end{array}$ & $<.02$ & $<.004$ & $<.009$ & $<.005$ & $<.029$ & $<.013$ & $<.024$ & $<.012$ & $<.016$ & $<.003$ & $<.004$ & $<.035$ & $<.027$ \\
\hline$\underset{\text { JAN }}{08} \cdots$ & -- & -- & -- & -- & -- & -- & -- & -- & -- & -- & -- & -- & -- \\
\hline$\underset{\text { MAR }}{04 \ldots}$ & $<.02$ & $<.004$ & $<.009$ & $<.005$ & $<.029$ & $<.013$ & $<.024$ & $<.012$ & $<.016$ & $<.003$ & $<.004$ & $<.035$ & $<.027$ \\
\hline$\underset{A P R}{09} \cdots$ & -- & -- & -- & -- & -- & -- & -- & -- & -- & -- & -- & -- & -- \\
\hline$\stackrel{13}{13} \cdot$ & -- & -- & -- & -- & -- & -- & -- & -- & -- & -- & -- & -- & -- \\
\hline JUL $^{02} \cdots$ & $<.02$ & $<.004$ & $<.009$ & $<.005$ & $<.029 \mathrm{mc}$ & E.004t & $<.024$ & $<.012$ & $<.016 \mathrm{mc}$ & $<.003$ & $<.004$ & $<.035$ & $<.027$ \\
\hline$\underset{A U G}{13} \cdots$ & -- & -- & -- & -- & -- & -- & -- & -- & -- & -- & -- & -- & -- \\
\hline $24 \ldots$ & $<.02 \mathrm{mc}$ & $<.004$ & $<.009$ & $<.005$ & $<.029 \mathrm{mc}$ & $<.013$ & $<.024$ & $<.012$ & $<.016 \mathrm{mc}$ & $<.003$ & $<.004$ & $<.035$ & $<.027$ \\
\hline Date & $\begin{array}{l}\text { Methyl } \\
\text { para- } \\
\text { thion, } \\
\text { water, } \\
\text { fltrd, } \\
\text { ug/L }\end{array}$ & $\begin{array}{c}\text { Metola- } \\
\text { chlor, } \\
\text { water, } \\
\text { fltrd, } \\
\text { ug/L }\end{array}$ & $\begin{array}{l}\text { Metri- } \\
\text { buzin, } \\
\text { water, } \\
\text { fltrd, } \\
\text { ug/L }\end{array}$ & $\begin{array}{l}\text { Moli- } \\
\text { nate, } \\
\text { water, } \\
\text { fltrd, } \\
\text { ug/L }\end{array}$ & $\begin{array}{l}\text { Naprop- } \\
\text { amide, } \\
\text { water, } \\
\text { fltrd, } \\
\text { ug/L }\end{array}$ & $\begin{array}{l}\mathrm{p}, \mathrm{p}^{\prime}- \\
\text { DDE, } \\
\text { water, } \\
\text { fltrd, } \\
\text { ug/L }\end{array}$ & $\begin{array}{l}\text { Para- } \\
\text { thion, } \\
\text { water, } \\
\text { fltrd, } \\
\text { ug/L }\end{array}$ & $\begin{array}{l}\text { Peb- } \\
\text { ulate, } \\
\text { water, } \\
\text { fltrd, } \\
\text { ug/L }\end{array}$ & $\begin{array}{l}\text { Pendi- } \\
\text { meth- } \\
\text { alin, } \\
\text { water, } \\
\text { fltrd, } \\
\text { ug/L }\end{array}$ & $\begin{array}{l}\text { Phorate, } \\
\text { water, } \\
\text { fltrd, } \\
\text { ug/L }\end{array}$ & $\begin{array}{c}\text { Prome- } \\
\text { ton, } \\
\text { water, } \\
\text { fltrd, } \\
\text { ug/L }\end{array}$ & $\begin{array}{c}\text { Propy- } \\
\text { zamide, } \\
\text { water, } \\
\text { fltrd, } \\
\text { ug/L }\end{array}$ & $\begin{array}{l}\text { Propa- } \\
\text { chlor, } \\
\text { water } \\
\text { fltrd, } \\
\text { ug/L }\end{array}$ \\
\hline SEP & & & & & & & & & & & & & \\
\hline$\stackrel{13}{13}$. & $<.015$ & $<.013$ & $<.006$ & $<.003$ & $<.007$ & $<.003$ & $<.010$ & $<.004$ & $<.022$ & $<.011$ & .01 & $<.004$ & $<.025$ \\
\hline$\underset{\text { JAN }}{08} \cdots$ & -- & -- & -- & -- & -- & -- & -- & -- & -- & -- & -- & -- & -- \\
\hline$\underset{\text { MAR }}{04 \ldots}$ & $<.015$ & $<.006$ & $<.006$ & $<.003$ & $<.007$ & $<.003$ & $<.010$ & $<.004$ & $<.022$ & $<.011$ & $\mathrm{E} .01 \mathrm{n}$ & $<.004$ & $<.025$ \\
\hline $\begin{array}{l}09 \\
A P R\end{array}$ & -- & -- & -- & -- & -- & -- & -- & -- & -- & -- & -- & -- & -- \\
\hline${ }_{\text {JUN }}^{13} \ldots$ & -- & -- & -- & -- & -- & -- & -- & -- & -- & -- & -- & -- & -- \\
\hline $\begin{array}{l}02 \ldots \\
\text { JUL }\end{array}$ & $<.015$ & $<.006$ & $<.006$ & $<.003$ & $<.007$ & $<.003$ & $<.010$ & $<.004$ & $<.022$ & $<.011$ & $\mathrm{E} .01 \mathrm{n}$ & $<.004$ & $<.025$ \\
\hline $\begin{array}{c}13 \ldots \\
\text { AUG } \\
24 \ldots\end{array}$ & $\begin{array}{c}-- \\
<.015\end{array}$ & $\begin{array}{c}-- \\
<.006\end{array}$ & $<.006$ & $<.003$ & $\begin{array}{c}-- \\
<.007\end{array}$ & $\begin{array}{c}-- \\
<.003\end{array}$ & $\begin{array}{c}-- \\
<.010\end{array}$ & $\begin{array}{c}-- \\
<.004\end{array}$ & $<.022$ & $\begin{array}{c}-- \\
<.011\end{array}$ & $\begin{array}{r}-- \\
<.01\end{array}$ & $\begin{array}{c}-- \\
<.004\end{array}$ & $\begin{array}{c}-- \\
<.025\end{array}$ \\
\hline
\end{tabular}


44 Water-Quality, Sediment-Quality, Stream-Habitat, and Biological Data for Mustang Bayou, Texas, 2004-05

Appendix 1. Periodically collected water-quality properties and constituents at six sites in Mustang Bayou near Houston, Texas, September 2004-August 2005-Continued.

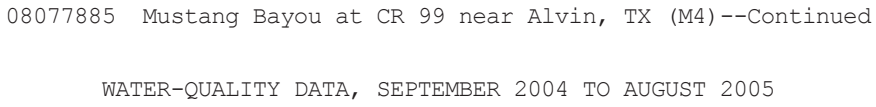


Appendix 1. Periodically collected water-quality properties and constituents at six sites in Mustang Bayou near Houston, Texas, September 2004-August 2005-Continued.

08077880 Mustang Bayou at CR 48 near Fresno, TX (M5)

WATER-QUALITY DATA, SEPTEMBER 2004 TO AUGUST 2005

\begin{tabular}{|c|c|c|c|c|c|c|c|c|c|c|c|c|c|}
\hline Date & Time & $\begin{array}{c}\text { Instan- } \\
\text { taneous } \\
\text { dis- } \\
\text { charge, } \\
\text { cfs }\end{array}$ & $\begin{array}{c}\text { Stream- } \\
\text { flow } \\
\text { sever- } \\
\text { ity, } \\
\text { code }\end{array}$ & $\begin{array}{l}\text { Sam- } \\
\text { pling } \\
\text { depth, } \\
\text { meters }\end{array}$ & $\begin{array}{c}\text { Temper- } \\
\text { ature, } \\
\text { water, } \\
\text { deg C }\end{array}$ & $\begin{array}{c}\text { Temper- } \\
\text { ature, } \\
\text { air, } \\
\operatorname{deg} \text { C }\end{array}$ & $\begin{array}{l}\text { Baro- } \\
\text { metric } \\
\text { pres- } \\
\text { sure, } \\
\text { mm Hg }\end{array}$ & $\begin{array}{c}\text { Dis- } \\
\text { solved } \\
\text { oxygen, } \\
\text { mg/L }\end{array}$ & $\begin{array}{l}\text { Dis- } \\
\text { solved } \\
\text { oxygen, } \\
\text { percent } \\
\text { of sat- } \\
\text { uration }\end{array}$ & $\begin{array}{l}\text { Specif. } \\
\text { conduc- } \\
\text { tance, } \\
\text { wat unf } \\
\text { uS/cm } \\
25 \mathrm{degc}\end{array}$ & $\begin{array}{l}\text { pH, } \\
\text { water, } \\
\text { unfltrd } \\
\text { field, } \\
\text { std } \\
\text { units }\end{array}$ & $\begin{array}{l}\text { Alka- } \\
\text { linity, } \\
\text { wat flt } \\
\text { inc tit } \\
\text { field, } \\
\mathrm{mg} / \mathrm{L} \text { as } \\
\mathrm{CaCO} 3\end{array}$ & $\begin{array}{c}\text { Carbon- } \\
\text { ate, } \\
\text { wat flt } \\
\text { incrm. } \\
\text { titr. } \\
\text { field, } \\
\text { mg/L }\end{array}$ \\
\hline $\begin{array}{l}\text { SEP } \\
\quad 14 \ldots \\
\text { NOV }\end{array}$ & 0935 & 3.98 & 3 & .30 & 27.2 & 29.0 & 758 & 5.6 & 71 & 625 & 7.5 & 177 & $E<1$ \\
\hline $\begin{array}{c}08 \\
\text { JAN }\end{array}$ & 0940 & 7.65 & 3 & .30 & 18.9 & 23.0 & 768 & 6.8 & 73 & 603 & 7.3 & 185 & $<1$ \\
\hline $\begin{array}{c}04 \ldots \\
\text { MAR }\end{array}$ & 1135 & 4.38 & 2 & .30 & 21.3 & 23.5 & 765 & 6.8 & 77 & 678 & 7.9 & 228 & 1 \\
\hline $\begin{array}{c}09 \ldots \\
\operatorname{APR}\end{array}$ & 0845 & -- & 3 & .30 & 16.8 & 17.0 & 760 & 7.1 & 74 & 233 & 7.4 & 80 & $<1$ \\
\hline $\begin{array}{l}13 \ldots \\
\text { JUN }\end{array}$ & 1210 & 3.39 & 2 & .14 & 24.7 & 27.0 & 762 & 13.4 & 162 & 624 & 8.3 & 200 & 2 \\
\hline $\begin{array}{l}02 \ldots \\
\text { JUL }\end{array}$ & 0940 & 4.21 & 3 & .30 & 27.0 & 27.5 & 757 & 5.2 & 67 & 617 & 7.5 & 179 & $<1$ \\
\hline $13 \ldots$ & 0945 & .965 & 2 & .30 & 29.7 & 32.0 & 765 & 2.5 & 33 & 527 & 7.3 & 133 & $<1$ \\
\hline $24 \ldots$ & 1210 & 3.80 & 3 & .30 & 31.1 & 33.0 & 762 & 5.1 & 69 & 625 & 7.4 & 100 & $<1$ \\
\hline Date & $\begin{array}{c}\text { Bicar- } \\
\text { bonate, } \\
\text { wat flt } \\
\text { incrm. } \\
\text { titr..' } \\
\text { field, } \\
\text { mg/L }\end{array}$ & $\begin{array}{l}\text { Color, } \\
\text { water, } \\
\text { fltrd, } \\
\text { Pt-Co } \\
\text { units }\end{array}$ & $\begin{array}{c}\text { Turbidity } \\
\text { white } \\
\text { light, } \\
\text { det ang } \\
90+/-30 \\
\text { corrctd } \\
\text { NTRU }\end{array}$ & $\begin{array}{l}\text { Sus- } \\
\text { pended } \\
\text { sedi- } \\
\text { ment } \\
\text { concen- } \\
\text { tration } \\
\text { mg/L }\end{array}$ & $\begin{array}{c}\text { Ammonia } \\
\text { water, } \\
\text { unfltrd } \\
\text { mg/L } \\
\text { as N }\end{array}$ & $\begin{array}{c}\text { BOD, } \\
\text { water, } \\
\text { unfltrd } \\
5 \text { day, } \\
20 \text { degC } \\
\mathrm{mg} / \mathrm{L}\end{array}$ & $\begin{array}{c}\text { CBOD, } \\
\text { water, } \\
\text { unfltrd } \\
5 \text { day, } \\
\text { mg/L }\end{array}$ & $\begin{array}{c}\text { E coli, } \\
\text { m-TEC } \\
\text { MF', } \\
\text { water, } \\
\text { col/ } \\
100 \mathrm{~mL}\end{array}$ & $\begin{array}{c}\text { Nitrite } \\
+ \\
\text { nitrate } \\
\text { water } \\
\text { fltrd, } \\
\text { mg/L } \\
\text { as N }\end{array}$ & $\begin{array}{c}\text { Nitrate } \\
\text { water, } \\
\text { fltrd, } \\
\text { mg/L } \\
\text { as N }\end{array}$ & $\begin{array}{c}\text { Nitrite } \\
\text { water, } \\
\text { fltrd, } \\
\text { mg/L } \\
\text { as N }\end{array}$ & $\begin{array}{l}\text { Total } \\
\text { nitro- } \\
\text { gen, } \\
\text { water, } \\
\text { unfltrd } \\
\text { mg/L }\end{array}$ & $\begin{array}{c}\text { Phos- } \\
\text { phorus, } \\
\text { water, } \\
\text { unfltrd } \\
\text { mg/L }\end{array}$ \\
\hline $\begin{array}{l}\mathrm{SEP} \\
14 \ldots\end{array}$ & E216 & -- & -- & 31 & .12 & 2.2 & -- & 550 & $.411 \mathrm{c}$ & .35 & $.058 \mathrm{C}$ & .83 & .09 \\
\hline $\begin{array}{l}\text { NOV } \\
\quad 08 \ldots \\
\text { JAN }\end{array}$ & 224 & 20 & 42 & 19 & .07 & 1.6 & 1.2 & E55k & .081 & .07 & .007 & .44 & .08 \\
\hline $\begin{array}{l}04 \ldots \\
\text { MAR }\end{array}$ & 276 & 15 & 12 & 102 & .04 & 1.3 & 1.1 & 80 & .131 & .13 & .005 & .32 & E. $04 \mathrm{n}$ \\
\hline $\begin{array}{c}09 \ldots \\
\mathrm{APR}\end{array}$ & 97 & $250 d$ & 78 & 56 & .10 & 3.9 & 3.4 & 1,800 & .060 & .05 & .009 & 1.3 & .14 \\
\hline$\underset{\text { JUN }}{13 \ldots}$ & 238 & 18 & 11 & 21 & .07 & 1.2 & 1.1 & $\mathrm{E} 140 \mathrm{k}$ & $<.016$ & -- & .002 & -- & E.03n \\
\hline$\underset{\text { JUL }}{02 \ldots}$ & 216 & 25 & 8.7 & 17 & $<.04$ & 1.4 & .8 & 350 & E.013n & -- & .002 & -- & .05 \\
\hline$\underset{\text { AUG }}{13} \ldots$ & 161 & 20 & 3.9 & 7 & $<.04$ & $\mathrm{E} 1.2$ & E1.1 & 300 & $<.016$ & -- & E.001n & -- & E.04n \\
\hline $24 \ldots$ & 122 & 12 & $<2.0$ & 6 & $<.04$ & 2.1 & 1.8 & $\mathrm{E} 60 \mathrm{k}$ & E.010n & -- & $\mathrm{E} .001 \mathrm{n}$ & -- & .04 \\
\hline Date & $\begin{array}{l}\text { Ortho- } \\
\text { phos- } \\
\text { phate, } \\
\text { water, } \\
\text { fltrd, } \\
\mathrm{mg} / \mathrm{L} \\
\text { as P }\end{array}$ & $\begin{array}{c}\text { Ammonia } \\
+ \\
\text { org-N, } \\
\text { water, } \\
\text { unfltrd } \\
\text { mg/L } \\
\text { as N }\end{array}$ & $\begin{array}{l}\text { Organic } \\
\text { nitro- } \\
\text { gen, } \\
\text { water, } \\
\text { unfltrd } \\
\mathrm{mg} / \mathrm{L}\end{array}$ & $\begin{array}{c}\text { Chloro- } \\
\text { phyll a } \\
\text { phyto- } \\
\text { plank- } \\
\text { ton, } \\
\text { fluoro } \\
\text { ug/L }\end{array}$ & $\begin{array}{l}\text { Pheo- } \\
\text { phytin } \\
\text { a, } \\
\text { phyto- } \\
\text { plank- } \\
\text { ton } \\
\text { ug/L }\end{array}$ & $\begin{array}{c}\text { Chlor- } \\
\text { ide, } \\
\text { water, } \\
\text { fltrd } \\
\text { mg/L }\end{array}$ & $\begin{array}{c}\text { Sulfate } \\
\text { water, } \\
\text { fltrd } \\
\text { mg/L }\end{array}$ & $\begin{array}{l}\text { Solids, } \\
\text { total, } \\
\text { sus- } \\
\text { pended } \\
\mathrm{mg} / \mathrm{L}\end{array}$ & $\begin{array}{l}\text { Solids, } \\
\text { dis- } \\
\text { solved, } \\
\text { fltrd } \\
\mathrm{mg} / \mathrm{L}\end{array}$ & $\begin{array}{c}\text { alpha- } \\
\text { HCH, } \\
\text { water, } \\
\text { fltrd } \\
\text { ug/L }\end{array}$ & $\begin{array}{c}2,6-\mathrm{Di}- \\
\text { ethyl- } \\
\text { aniline } \\
\text { water } \\
\text { fltrd } \\
\text { ug/L }\end{array}$ & $\begin{array}{l}\text { Aceto- } \\
\text { chlor, } \\
\text { water, } \\
\text { fltrd } \\
\text { ug/L }\end{array}$ & $\begin{array}{c}\text { Ala- } \\
\text { chlor, } \\
\text { water, } \\
\text { fltrd } \\
\text { ug/L }\end{array}$ \\
\hline $\begin{array}{l}\mathrm{SEP} \\
\quad 14 \ldots\end{array}$ & $.057 \mathrm{C}$ & .42 & .30 & .9 & 1.4 & 65.9 & 24.0 & -- & 362 & $<.005$ & $<.006$ & $<.006$ & $<.005$ \\
\hline $\begin{array}{l}\text { NOV } \\
08 \ldots \\
\text { JAN }\end{array}$ & .045 & .36 & .29 & 1.9 & 1.4 & 62.2 & 16.6 & 14 & 343 & -- & -- & -- & -- \\
\hline $\begin{array}{l}04 \ldots \\
\text { MAR }\end{array}$ & .028 & .19 & .14 & 1.2 & .7 & 66.0 & 19.9 & 17 & 395 & $<.005$ & $<.006$ & $<.006$ & $<.005$ \\
\hline $\begin{array}{c}09 \ldots \\
A P R\end{array}$ & .038 & 1.2 & 1.1 & 1.2 & 3.0 & 16.4 & 6.7 & 38 & 153 & -- & -- & -- & -- \\
\hline${ }_{\text {JUN }}^{13} \ldots$ & .008 & .28 & .22 & 2.2 & 1.6 & 65.9 & 21.4 & 12 & 342 & -- & -- & -- & -- \\
\hline$\underset{\text { JUL }}{02 \ldots}$ & E.005n & .34 & -- & .9 & 1.4 & 67.7 & 20.6 & $<10$ & 348 & $<.005$ & $<.006$ & $<.006$ & $<.005$ \\
\hline$\underset{\text { AUG }}{13} \ldots$ & E.004n & .45 & -- & 1.1 & 1.6 & 68.4 & 14.2 & $<10$ & 291 & -- & -- & -- & -- \\
\hline & .028 & .24 & -- & 1.4 & 1.0 & 68.7 & 18.1 & $<10$ & 354 & $<.005$ & $<.006$ & $<.006$ & $<.005$ \\
\hline
\end{tabular}




\section{Water-Quality, Sediment-Quality, Stream-Habitat, and Biological Data for Mustang Bayou, Texas, 2004-05}

Appendix 1. Periodically collected water-quality properties and constituents at six sites in Mustang Bayou near Houston, Texas, September 2004-August 2005-Continued.

08077880 Mustang Bayou at CR 48 near Fresno, TX (M5)--Continued

WATER-QUALITY DATA, SEPTEMBER 2004 TO AUGUST 2005

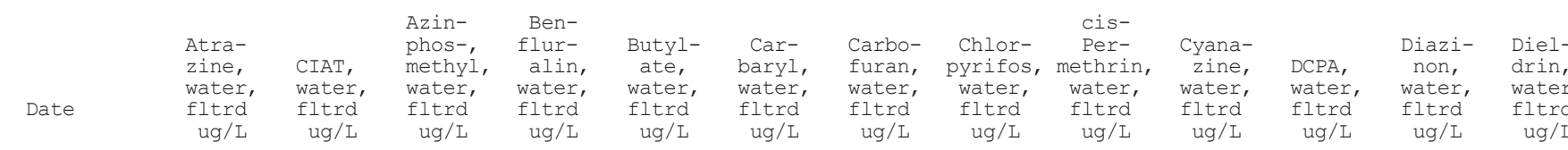

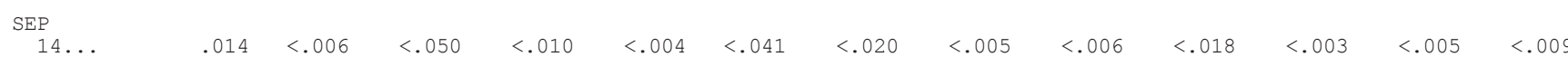

NOV 14.

08.
JAN

JAN $04 \ldots$

MAR

$09 .$.

$\mathrm{APR}$
$13 .$.

JUN

JUL 02.

JUL $13 .$.

AUG

$24 \ldots$

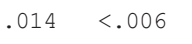

$.050<.01$

-- --

$.010<.006$

.05

$<.01$

$<.00$

$<.041$

$<.020<.005$

$--$

$--$

$--$

$-1$

$<.009$

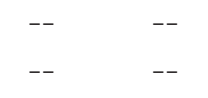

.209 E.041mc

$<.050 \mathrm{mc}$
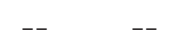

$--$

-- --

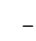

$.017<.006 \mathrm{mc}$

$<.050 \mathrm{mc}<.010$

$<.004$

$<.041 \mathrm{mc}<.020 \mathrm{mc}<.005$

$<.006$

$<.003$

$<.005$

$<.009$

$\begin{array}{ccc} & & \text { Ethal- } \\ \text { Disul- } & & \text { flur- } \\ \text { foton, EPTC, } & \text { alin, } \\ \text { water, water, } & \text { water, } \\ \text { fltrd } & \text { fltrd } & \text { fltrd } \\ \text { ug/L } & \text { ug/L } & \text { ug/L }\end{array}$

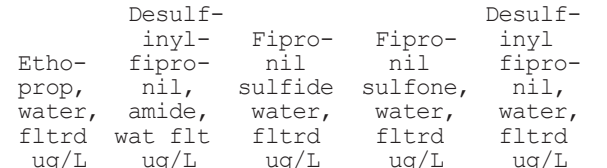

Fipro-

nil, Fonofos, Mala-

water, water, water, water, water,

Date

$\mathrm{ug} / \mathrm{L}$

ug/L

$\mathrm{ug} / \mathrm{L}$

$\begin{array}{cc}\mathrm{ug} / \mathrm{L} & \mathrm{ug} / \mathrm{L}\end{array}$

$<.02<.004<.009$

$<.005<.029$

$<.013$

$<.024<.012$

$<.016$

ug/L

fltrd

fltrd

water,

SEP
$14 \ldots$

NOV
$08 \ldots$

JAN

$04 \ldots$

09. .

APR

13.

JUN
$02 \ldots$

JUL $13 \ldots$

AUG

$24 \ldots$

$--\quad-$

$--$

$-.02$

$<.009$

$<.005<.029$

$--$

$--$

$--$

$<.003$

$<.004$

$<.035<.027$

$<.02<.00$

$-$

$\begin{array}{ll}-- & -- \\ -- & --\end{array}$

.0

$<.024$

$<.012$

$<.016$

$<.003$

$<.004$

$<.035$

$<.027$

$<.005<.029 \mathrm{mc}$

$--$

$--$

$--$

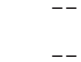

$--$
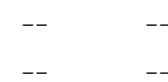

$<.02 \mathrm{mc}<.004$

$<.009$

$<.005<.029 m \mathrm{c}<.013$

$<.024$

$--$

$<.016 \mathrm{mc}$

$<.003$

$<.004$

$<.035$

E. $019 n$

Methyl Metola-
para-

Metola- Metri-

thion, chlor, buzin,

Moli-

Naprop-

Date

water, water,

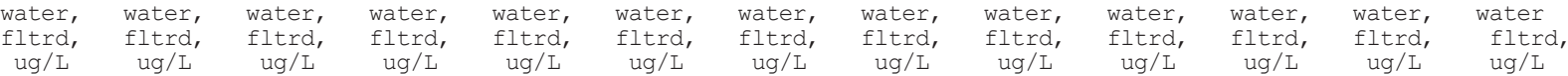

nate, amide,

water,

$\begin{array}{ll}\text { p,p'- } & \text { Para- } \\ \text { DDE, } & \text { thion, } \\ \text { water, } & \text { water, } \\ \text { fltrd, } & \text { fltrd, }\end{array}$

Peb-
ulate,
water,
fltrd,

Pendi-

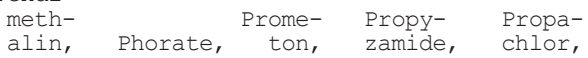

water, water, water, water, water,

$\mathrm{SEP}$
14.

$<.015<.013<.006<.003<.007$

$<.003<.010$

$<.004$

$<.022<.011$

.01

$<.004<.025$

08 .

JAN

04.
MAR

$--\quad-$

$--$

$--$

$--$

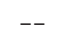

$--$

$--\quad--$

$--$

P

$13 \ldots$

JUN
$02 \ldots$

JUL

13
AUG

$<.015$
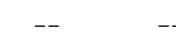

$-1$

$<.003$

$<.010$

$<.004$

$<.022$

$<.011$

.02

$<.004<.025$

$24 \ldots$

$<.015<.006$

$<.006$

$<.003$

$<.007$

$--$
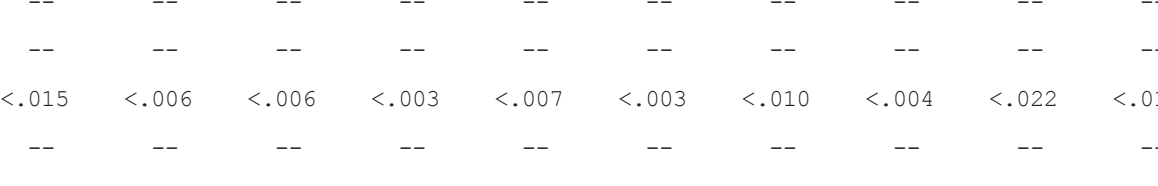

$--$

$--$

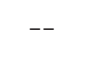

$--$

$<.004<.022$

$<.011$

.02

$<.004<.025$

$<.015<.006<.00$

$<.003$

$<.007$

$<.003<.010$

$<.004<.022$

$<.011$

E.01n

$<.004<.025$ 
Appendix 1. Periodically collected water-quality properties and constituents at six sites in Mustang Bayou near Houston, Texas, September 2004-August 2005-Continued.

\begin{tabular}{|c|c|c|c|c|c|c|c|c|}
\hline \multirow[b]{2}{*}{$\begin{array}{l}\text { Pro- } \\
\text { panil, } \\
\text { water, } \\
\text { fltrd } \\
\text { ug/L }\end{array}$} & \multicolumn{2}{|c|}{ WATER-QUALITY DAT } & \multicolumn{2}{|c|}{ A, SEPTEMBER 2004} & \multicolumn{3}{|c|}{ TO AUGUST 2005} & \multirow[b]{2}{*}{$\begin{array}{l}\text { Tri- } \\
\text { flur- } \\
\text { alin, } \\
\text { water, } \\
\text { fltrd } \\
\text { ug/L }\end{array}$} \\
\hline & $\begin{array}{c}\text { Propar- } \\
\text { gite, } \\
\text { water, } \\
\text { fltrd } \\
\text { ug/L }\end{array}$ & $\begin{array}{l}\text { Sima- } \\
\text { zine, } \\
\text { water, } \\
\text { fltrd } \\
\text { ug/L }\end{array}$ & $\begin{array}{c}\text { Tebu- } \\
\text { thiuron, } \\
\text { water, } \\
\text { fltrd } \\
\text { ug/L }\end{array}$ & $\begin{array}{c}\text { Terbu- } \\
\text { cil, } \\
\text { water, } \\
\text { fltrd } \\
\text { ug/L }\end{array}$ & $\begin{array}{l}\text { Terbu- } \\
\text { fos, } \\
\text { water, } \\
\text { fltrd } \\
\text { ug/L }\end{array}$ & $\begin{array}{c}\text { Thio- } \\
\text { bencarb, } \\
\text { water, } \\
\text { fltrd } \\
\text { ug/L }\end{array}$ & $\begin{array}{l}\text { Tri- } \\
\text { allate, } \\
\text { water, } \\
\text { fltrd } \\
\text { ug/L }\end{array}$ & \\
\hline$<.011$ & $<.02$ & $<.005$ & $<.02$ & $<.034$ & $<.02$ & $<.010$ & $<.002$ & $<.009$ \\
\hline-- & -- & -- & -- & -- & -- & -- & -- & -- \\
\hline$<.011$ & $<.02$ & $<.020$ & .03 & $<.034$ & $<.02$ & $<.010$ & $<.006$ & $<.009$ \\
\hline-- & -- & -- & -- & -- & -- & -- & -- & -- \\
\hline-- & -- & -- & -- & -- & -- & -- & -- & -- \\
\hline$<.011$ & $<.02$ & E.003n & .03 & $<.034 \mathrm{mc}$ & $<.02$ & $<.010$ & $<.006$ & $<.009$ \\
\hline-- & -- & -- & -- & -- & -- & -- & -- & -- \\
\hline$<.011$ & $<.02$ & $<.005$ & $<.02$ & $<.034 \mathrm{mc}$ & $<.02$ & $<.010$ & $<.006$ & $<.009$ \\
\hline
\end{tabular}




\section{Water-Quality, Sediment-Quality, Stream-Habitat, and Biological Data for Mustang Bayou, Texas, 2004-05}

Appendix 1. Periodically collected water-quality properties and constituents at six sites in Mustang Bayou near Houston, Texas, September 2004-August 2005-Continued.

08077877 Mustang Bayou at Evergreen Road near Fresno, TX (M6)

WATER-QUALITY DATA, SEPTEMBER 2004 TO AUGUST 2005

\begin{tabular}{|c|c|c|c|c|c|c|c|c|c|c|c|c|c|}
\hline Date & Time & $\begin{array}{c}\text { Instan- } \\
\text { taneous } \\
\text { dis- } \\
\text { charge, } \\
\text { cfs }\end{array}$ & $\begin{array}{l}\text { Stream- } \\
\text { flow } \\
\text { sever- } \\
\text { ity, } \\
\text { code }\end{array}$ & $\begin{array}{l}\text { Sam- } \\
\text { pling } \\
\text { depth, } \\
\text { meters }\end{array}$ & $\begin{array}{l}\text { Temper- } \\
\text { ature, } \\
\text { water, } \\
\text { deg C }\end{array}$ & $\begin{array}{c}\text { Temper- } \\
\text { ature, } \\
\text { air, } \\
\text { deg C }\end{array}$ & $\begin{array}{l}\text { Baro- } \\
\text { metric } \\
\text { pres- } \\
\text { sure, } \\
\text { mm Hg }\end{array}$ & $\begin{array}{c}\text { Dis- } \\
\text { solved } \\
\text { oxygen, } \\
\text { mg/L }\end{array}$ & $\begin{array}{l}\text { Dis- } \\
\text { solved } \\
\text { oxygen, } \\
\text { percent } \\
\text { of sat- } \\
\text { uration }\end{array}$ & $\begin{array}{l}\text { Specif. } \\
\text { conduc- } \\
\text { tance, } \\
\text { wat unf } \\
\text { uS/cm } \\
25 \text { degC }\end{array}$ & $\begin{array}{l}\text { pH, } \\
\text { water, } \\
\text { unfltrd } \\
\text { field, } \\
\text { std } \\
\text { units }\end{array}$ & $\begin{array}{l}\text { Alka- } \\
\text { linity, } \\
\text { wat flt } \\
\text { inc tit } \\
\text { field, } \\
\text { mg/L as } \\
\text { CaCo3 }\end{array}$ & $\begin{array}{c}\text { Carbon- } \\
\text { ate, } \\
\text { wat flt } \\
\text { incrm. } \\
\text { titr., } \\
\text { field, } \\
\text { mg/L }\end{array}$ \\
\hline $\begin{array}{l}\mathrm{SEP} \\
\quad 14 \ldots \\
\mathrm{NOV}\end{array}$ & 0845 & .103 & 3 & .30 & 26.2 & 29.0 & 758 & 3.2 & 40 & 378 & 7.1 & 81 & $<1$ \\
\hline$\underset{\text { JAN }}{08 \ldots}$ & 0910 & .647 & 3 & .08 & 17.3 & 22.0 & 768 & 4.7 & 48 & 108 & 6.3 & 30 & $<1$ \\
\hline$\underset{\text { MAR }}{04 \ldots}$ & 1040 & .290 & 2 & .04 & 20.3 & 22.5 & 765 & 4.7 & 52 & 391 & 7.1 & 88 & $<1$ \\
\hline $\begin{array}{c}09 \ldots \\
\text { APR }\end{array}$ & 0800 & 16.4 & 3 & .30 & 16.2 & 15.0 & 760 & 6.0 & 61 & 105 & 6.5 & 35 & $<1$ \\
\hline$\underset{\text { JUN }}{13} \ldots$ & 1245 & .223 & 2 & .12 & 26.3 & 27.0 & 767 & 10.5 & 130 & 786 & 7.8 & 154 & $<1$ \\
\hline JUL $^{02} \cdots$ & 0900 & 3.14 & 3 & .30 & 25.6 & 26.0 & 758 & 4.9 & 60 & 159 & 7.0 & 51 & $<1$ \\
\hline $\begin{array}{l}13 \\
\text { AUG }\end{array}$ & 0855 & .00 & 1 & .08 & 29.1 & 31.0 & 764 & 2.8 & 36 & 655 & 7.2 & 79 & $<1$ \\
\hline $24 \ldots$ & 1140 & .00 & 3 & .06 & 30.3 & 32.5 & 763 & 1.8 & 24 & 343 & 7.0 & 207 & 1 \\
\hline Date & $\begin{array}{c}\text { Bicar- } \\
\text { bonate, } \\
\text { wat flt } \\
\text { incrm. } \\
\text { titr. } \\
\text { field, } \\
\text { mg/L }\end{array}$ & $\begin{array}{l}\text { T } \\
\text { Color, } \\
\text { water, } \\
\text { fltrd, } \\
\text { Pt-Co } \\
\text { units }\end{array}$ & $\begin{array}{c}\text { Turbidity } \\
\text { white } \\
\text { light, } \\
\text { det ang } \\
90+/-30 \\
\text { corrctd } \\
\text { NTRU }\end{array}$ & $\begin{array}{l}\text { Sus- } \\
\text { pended } \\
\text { sedi- } \\
\text { ment } \\
\text { concen- } \\
\text { tration } \\
\text { mg/L }\end{array}$ & $\begin{array}{c}\text { Ammonia } \\
\text { water, } \\
\text { unfltrd } \\
\mathrm{mg} / \mathrm{L} \\
\text { as N }\end{array}$ & $\begin{array}{c}\text { BOD, } \\
\text { water, } \\
\text { unfltrd } \\
5 \text { day, } \\
20 \text { degC } \\
\mathrm{mg} / \mathrm{L}\end{array}$ & $\begin{array}{c}\text { CBOD, } \\
\text { water, } \\
\text { unfltrd } \\
5 \mathrm{day}, \\
\mathrm{mg} / \mathrm{L}\end{array}$ & $\begin{array}{c}\text { E coli, } \\
\text { m-TEC } \\
\text { MF, } \\
\text { water, } \\
\text { col/ } \\
100 \mathrm{~mL}\end{array}$ & $\begin{array}{c}\text { Nitrite } \\
+ \\
\text { nitrate } \\
\text { water } \\
\text { fltrd, } \\
\text { mg/L } \\
\text { as N }\end{array}$ & $\begin{array}{c}\text { Nitrate } \\
\text { water, } \\
\text { fltrd, } \\
\text { mg/L } \\
\text { as N }\end{array}$ & $\begin{array}{c}\text { Nitrite } \\
\text { water, } \\
\text { fltrd, } \\
\text { mg/L } \\
\text { as N }\end{array}$ & $\begin{array}{l}\text { Total } \\
\text { nitro- } \\
\text { gen, } \\
\text { water, } \\
\text { unfltrd } \\
\text { mg/L }\end{array}$ & $\begin{array}{c}\text { Phos- } \\
\text { phorus, } \\
\text { water, } \\
\text { unfltrd } \\
\text { mg/L }\end{array}$ \\
\hline SEP & & & & & & & & & & & & & \\
\hline$\stackrel{14}{14}$ & 99 & -- & -- & 87 & .10 & 5.3 & -- & 800 & $<.016$ & -- & E.001n & -- & .11 \\
\hline $\begin{array}{l}08 \\
\text { JAN }\end{array}$ & 37 & $175 d$ & 110 & 66 & .03 & 4.0 & 3.2 & 270 & E.015n & -- & .003 & -- & .17 \\
\hline $\begin{array}{l}04 \ldots \\
M A R\end{array}$ & 108 & $175 d$ & 120 & 149 & .06 & 2.7 & 2.1 & 84 & E.008n & -- & $\mathrm{E} .001 \mathrm{n}$ & -- & .13 \\
\hline$\underset{A P R}{09} \cdots$ & 43 & $300 d$ & 96 & 30 & .09 & 3.5 & 2.6 & 4,000 & .052 & .04 & .007 & 1.5 & .14 \\
\hline$\stackrel{13}{13}$. & 186 & $50 d$ & 32 & 164 & .08 & 2.6 & 2.1 & E75k & $<.016$ & -- & E.001n & -- & .06 \\
\hline${ }_{\text {JUL }}^{02} \ldots$ & 62 & $200 d$ & 94 & 75 & .04 & 5.2 & 4.4 & 1,400 & E.014n & -- & E.001n & -- & .18 \\
\hline$\underset{\text { AUG }}{13} \ldots$ & 96 & $80 d$ & 140 & 176 & .04 & 8.1 & 6.4 & 520 & $<.016$ & -- & $\mathrm{E} .001 \mathrm{n}$ & -- & .26 \\
\hline $24 \ldots$ & 251 & $200 d$ & 92 & 90 & .12 & 3.5 & 2.4 & 500 & E.009n & -- & E.001n & -- & .14 \\
\hline Date & $\begin{array}{l}\text { Ortho- } \\
\text { phos- } \\
\text { phate, } \\
\text { water, } \\
\text { fltrd, } \\
\text { mg/L } \\
\text { as P }\end{array}$ & $\begin{array}{c}\text { Ammonia } \\
+ \\
\text { org-N, } \\
\text { water, } \\
\text { unfltrd } \\
\text { mg/L } \\
\text { as N }\end{array}$ & $\begin{array}{l}\text { Organic } \\
\text { nitro- } \\
\text { gen, } \\
\text { water, } \\
\text { unfltrd } \\
\text { mg/L }\end{array}$ & $\begin{array}{l}\text { Chloro- } \\
\text { phyll a } \\
\text { phyto- } \\
\text { plank- } \\
\text { ton, } \\
\text { fluoro } \\
\text { ug/L }\end{array}$ & $\begin{array}{l}\text { Pheo- } \\
\text { phytin } \\
\text { a, } \\
\text { phyto- } \\
\text { plank- } \\
\text { ton } \\
\text { ug/L }\end{array}$ & $\begin{array}{c}\text { Chlor- } \\
\text { ide, } \\
\text { water, } \\
\text { fltrd } \\
\text { mg/L }\end{array}$ & $\begin{array}{c}\text { Sulfate } \\
\text { water, } \\
\text { fltrd } \\
\text { mg/L }\end{array}$ & $\begin{array}{l}\text { Solids, } \\
\text { total, } \\
\text { sus- } \\
\text { pended } \\
\text { mg/L }\end{array}$ & $\begin{array}{l}\text { Solids, } \\
\text { dis- } \\
\text { solved, } \\
\text { fltrd } \\
\text { mg/L }\end{array}$ & $\begin{array}{l}\text { alpha- } \\
\text { HCH, } \\
\text { water, } \\
\text { fltrd } \\
\text { ug/L }\end{array}$ & $\begin{array}{c}2,6-D i- \\
\text { ethyl- } \\
\text { aniline } \\
\text { water } \\
\text { fltrd } \\
\text { ug/L }\end{array}$ & $\begin{array}{l}\text { Aceto- } \\
\text { chlor, } \\
\text { water, } \\
\text { fltrd } \\
\text { ug/L }\end{array}$ & $\begin{array}{c}\text { Ala- } \\
\text { chlor, } \\
\text { water, } \\
\text { fltrd } \\
\text { ug/L }\end{array}$ \\
\hline SEP & & & & & & & & & & & & & \\
\hline$\stackrel{14 \ldots}{\text { NOV }}$ & $<.006$ & 1.2 & 1.1 & 20.6 & 12.6 & 69.5 & 24.0 & -- & 218 & $<.005$ & $<.006$ & $<.006$ & $<.005$ \\
\hline$\underset{\text { JAN }}{08}$ & .014 & 1.2 & 1.2 & 4.8 & 5.9 & 5.81 & 5.1 & 44 & 79 & -- & -- & -- & -- \\
\hline$\underset{M A R}{04 \ldots}$ & E.003n & 1.2 & 1.1 & 4.1 & 6.1 & 44.8 & 25.5 & $152 d$ & 228 & $<.005$ & $<.006$ & $<.006$ & $<.005$ \\
\hline$\underset{A P R}{09} \cdots$ & .031 & 1.4 & 1.4 & 1.2 & 5.8 & 5.95 & 2.7 & 58 & 87 & -- & -- & -- & -- \\
\hline${ }_{\text {JUN }}^{13} \cdots$ & $<.006$ & .91 & .83 & .3 & .4 & 119 & 47.2 & $98 d$ & 426 & -- & -- & -- & -- \\
\hline$\underset{\text { JUL }}{02 \ldots}$ & .008 & 1.6 & 1.5 & 19.7 & 10.3 & 9.88 & 5.4 & $82 d$ & 99 & $<.005$ & $<.006$ & $<.006$ & $<.005$ \\
\hline$\underset{\text { AUG }}{13} \ldots$ & $\mathrm{E} .004 \mathrm{n}$ & 2.8 & 2.7 & 56.6 & 21.9 & 104 & 68.4 & $182 \mathrm{~d}$ & 407 & -- & -- & -- & -- \\
\hline $24 \ldots$ & $<.006$ & 1.2 & 1.1 & 11.9 & 8.8 & 39.6 & 11.9 & $240 d$ & 200 & $<.005$ & $<.006$ & $<.006$ & $<.005$ \\
\hline
\end{tabular}


Appendix 1. Periodically collected water-quality properties and constituents at six sites in Mustang Bayou near Houston, Texas, September 2004-August 2005-Continued.

08077877 Mustang Bayou at Evergreen Road near Fresno, TX (M6)--Continued WATER-QUALITY DATA, SEPTEMBER 2004 TO AUGUST 2005

\begin{tabular}{|c|c|c|c|c|c|c|c|c|c|c|c|c|c|}
\hline Date & $\begin{array}{l}\text { Atra- } \\
\text { zine, } \\
\text { water, } \\
\text { fltrd } \\
\text { ug/L }\end{array}$ & $\begin{array}{l}\text { CIAT, } \\
\text { water, } \\
\text { fltrd } \\
\text { ug/L }\end{array}$ & $\begin{array}{l}\text { Azin- } \\
\text { phos-, } \\
\text { methyl, } \\
\text { water, } \\
\text { fltrd } \\
\text { ug/L }\end{array}$ & $\begin{array}{l}\text { Ben- } \\
\text { flur- } \\
\text { alin, } \\
\text { water, } \\
\text { fltrd } \\
\text { ug/L }\end{array}$ & $\begin{array}{l}\text { Butyl- } \\
\text { ate, } \\
\text { water, } \\
\text { fltrd } \\
\text { ug/L }\end{array}$ & $\begin{array}{l}\text { Car- } \\
\text { baryl, } \\
\text { water, } \\
\text { fltrd } \\
\text { ug/L }\end{array}$ & $\begin{array}{l}\text { Carbo- } \\
\text { furan, } \\
\text { water, } \\
\text { fltrd } \\
\text { ug/L }\end{array}$ & $\begin{array}{l}\text { Chlor- } \\
\text { pyrifos, } \\
\text { water, } \\
\text { fltrd } \\
\text { ug/L }\end{array}$ & $\begin{array}{c}\text { cis- } \\
\text { Per- } \\
\text { methrin, } \\
\text { water, } \\
\text { fltrd } \\
\text { ug/L }\end{array}$ & $\begin{array}{c}\text { Cyana- } \\
\text { zine, } \\
\text { water, } \\
\text { fltrd } \\
\text { ug/L }\end{array}$ & $\begin{array}{l}\text { DCPA, } \\
\text { water, } \\
\text { fltrd } \\
\text { ug/L }\end{array}$ & $\begin{array}{l}\text { Diazi- } \\
\text { non, } \\
\text { water, } \\
\text { fltrd } \\
\text { ug/L }\end{array}$ & $\begin{array}{l}\text { Diel- } \\
\text { drin, } \\
\text { water, } \\
\text { fltrd } \\
\text { ug/L }\end{array}$ \\
\hline SEP & & & & & & & & & & & & & \\
\hline $\begin{array}{c}14 \ldots \\
\text { NOV }\end{array}$ & .031 & E.006 & $<.050$ & $<.010$ & $<.004$ & $<.041$ & $<.020$ & $<.005$ & $<.006$ & $<.018$ & $<.003$ & $<.005$ & $<.009$ \\
\hline$\underset{\text { JAN }}{08} \cdots$ & -- & -- & -- & -- & -- & -- & -- & -- & -- & -- & -- & -- & -- \\
\hline$\underset{M A R}{04} \ldots$ & .029 & E.006n & $<.050$ & $<.010$ & $<.004$ & $<.041$ & $<.020$ & $<.005$ & $<.006$ & $<.018$ & $<.003$ & $<.005$ & $<.009$ \\
\hline $\begin{array}{c}09 \\
\mathrm{APR}\end{array}$ & -- & -- & -- & -- & -- & -- & -- & -- & -- & -- & -- & -- & -- \\
\hline$\underset{J U N}{13} \ldots$ & -- & -- & -- & -- & -- & -- & -- & -- & -- & -- & -- & -- & -- \\
\hline${ }_{\text {JUL }}^{02} \ldots$ & 1.42 & $\mathrm{E} .167 \mathrm{mc}$ & $<.050 \mathrm{mc}$ & $<.010$ & $<.004$ & $\mathrm{E} .041 \mathrm{mc}$ & $<.020 \mathrm{mc}$ & $<.005$ & $<.006$ & $<.018$ & $<.003$ & $<.010$ & $<.009$ \\
\hline${ }_{\text {AUG }}^{13} \ldots$ & -- & -- & -- & -- & -- & -- & -- & -- & -- & -- & -- & -- & -- \\
\hline $24 \ldots$ & .016 & $<.006 \mathrm{mc}$ & $<.050 \mathrm{mc}$ & $<.010$ & $<.004$ & $<.041 \mathrm{mc}$ & $<.020 \mathrm{mc}$ & $<.005$ & $<.006$ & $<.018$ & $<.003$ & $<.005$ & $<.009$ \\
\hline Date & $\begin{array}{l}\text { Disul- } \\
\text { foton, } \\
\text { water, } \\
\text { fltrd } \\
\text { ug/L }\end{array}$ & $\begin{array}{l}\text { EPTC, } \\
\text { water, } \\
\text { fltrd } \\
\text { ug/L }\end{array}$ & $\begin{array}{l}\text { Ethal- } \\
\text { flur- } \\
\text { alin, } \\
\text { water, } \\
\text { fltrd } \\
\text { ug/L }\end{array}$ & $\begin{array}{l}\text { Etho- } \\
\text { prop, } \\
\text { water, } \\
\text { fltrd } \\
\text { ug/L }\end{array}$ & $\begin{array}{c}\text { Desulf- } \\
\text { inyl- } \\
\text { fipro- } \\
\text { nil, } \\
\text { amide, } \\
\text { wat flt } \\
\text { ug/L }\end{array}$ & $\begin{array}{l}\text { Fipro- } \\
\text { nil } \\
\text { sulfide } \\
\text { water, } \\
\text { fltrd } \\
\text { ug/L }\end{array}$ & $\begin{array}{l}\text { Fipro- } \\
\text { nil } \\
\text { sulfone, } \\
\text { water, } \\
\text { fltrd } \\
\text { ug/L }\end{array}$ & $\begin{array}{l}\text { Desulf- } \\
\text { inyl } \\
\text { fipro- } \\
\text { nil, } \\
\text { water, } \\
\text { fltrd } \\
\text { ug/L }\end{array}$ & $\begin{array}{l}\text { Fipro- } \\
\text { nil, } \\
\text { water, } \\
\text { fltrd } \\
\text { ug/L }\end{array}$ & $\begin{array}{c}\text { Fonofos, } \\
\text { water, } \\
\text { fltrd } \\
\text { ug/L }\end{array}$ & $\begin{array}{l}\text { Lindane, } \\
\text { water, } \\
\text { fltrd } \\
\text { ug/L }\end{array}$ & $\begin{array}{l}\text { Linuron, } \\
\text { water, } \\
\text { fltrd } \\
\text { ug/L }\end{array}$ & $\begin{array}{l}\text { Mala- } \\
\text { thion, } \\
\text { water, } \\
\text { fltrd } \\
\text { ug/L }\end{array}$ \\
\hline SEP & & & & & & & & & & & & & \\
\hline$\stackrel{14 \ldots}{\text { NOV }}$ & $<.02$ & $<.004$ & $<.009$ & $<.005$ & $<.029$ & $<.013$ & $<.024$ & $<.012$ & $<.016$ & $<.003$ & $<.004$ & $<.035$ & $<.027$ \\
\hline$\underset{\text { JAN }}{08} \cdots$ & -- & -- & -- & -- & -- & -- & -- & -- & -- & -- & -- & -- & -- \\
\hline$\underset{\text { MAR }}{04 \ldots}$ & $<.02$ & $<.004$ & $<.009$ & $<.005$ & $<.029$ & $<.013$ & $<.024$ & $<.012$ & $<.016$ & $<.003$ & $<.004$ & $<.035$ & $<.027$ \\
\hline$\underset{A P R}{09} \cdots$ & -- & -- & -- & -- & -- & -- & -- & -- & -- & -- & -- & -- & -- \\
\hline$\stackrel{13}{13} \cdot$ & -- & -- & -- & -- & -- & -- & -- & -- & -- & -- & -- & -- & -- \\
\hline JUL $^{02} \cdots$ & $<.02$ & $<.004$ & $<.009$ & $<.005$ & E.002mtc & E.003t & E.006t & E.005t & E.003mtc & $<.003$ & $<.004$ & $<.035$ & .097 \\
\hline$\underset{A U G}{13} \cdots$ & -- & -- & -- & -- & -- & -- & -- & -- & -- & -- & -- & -- & -- \\
\hline $24 \ldots$ & $<.02 \mathrm{mc}$ & $<.004$ & $<.009$ & $<.005$ & $<.029 \mathrm{mc}$ & $<.013$ & $<.024$ & $<.012<$ & $<.016 \mathrm{mc}$ & $<.003$ & $<.004$ & $<.035$ & $<.027$ \\
\hline Date & $\begin{array}{l}\text { Methyl } \\
\text { para- } \\
\text { thion, } \\
\text { water, } \\
\text { fltrd, } \\
\text { ug/L }\end{array}$ & $\begin{array}{c}\text { Metola- } \\
\text { chlor, } \\
\text { water, } \\
\text { fltrd, } \\
\text { ug/L }\end{array}$ & $\begin{array}{l}\text { Metri- } \\
\text { buzin, } \\
\text { water, } \\
\text { fltrd, } \\
\text { ug/L }\end{array}$ & $\begin{array}{l}\text { Moli- } \\
\text { nate, } \\
\text { water, } \\
\text { fltrd, } \\
\text { ug/L }\end{array}$ & $\begin{array}{l}\text { Naprop- } \\
\text { amide, } \\
\text { water, } \\
\text { fltrd, } \\
\text { ug/L }\end{array}$ & $\begin{array}{l}\mathrm{p}, \mathrm{p}^{\prime}- \\
\mathrm{DDE}, \\
\text { water, } \\
\text { fltrd, } \\
\text { ug/L }\end{array}$ & $\begin{array}{l}\text { Para- } \\
\text { thion, } \\
\text { water, } \\
\text { fltrd, } \\
\text { ug/L }\end{array}$ & $\begin{array}{l}\text { Peb- } \\
\text { ulate, } \\
\text { water, } \\
\text { fltrd, } \\
\text { ug/L }\end{array}$ & $\begin{array}{l}\text { Pendi- } \\
\text { meth- } \\
\text { alin, } \\
\text { water, } \\
\text { fltrd, } \\
\text { ug/L }\end{array}$ & $\begin{array}{l}\text { Phorate, } \\
\text { water, } \\
\text { fltrd, } \\
\text { ug/L }\end{array}$ & $\begin{array}{c}\text { Prome- } \\
\text { ton, } \\
\text { water, } \\
\text { fltrd, } \\
\text { ug/L }\end{array}$ & $\begin{array}{c}\text { Propy- } \\
\text { zamide, } \\
\text { water, } \\
\text { fltrd, } \\
\text { ug/L }\end{array}$ & $\begin{array}{l}\text { Propa- } \\
\text { chlor, } \\
\text { water } \\
\text { fltrd, } \\
\text { ug/L }\end{array}$ \\
\hline SEP & & & & & & & & & & & & & \\
\hline$\stackrel{14}{14}$ & $<.015$ & $<.013$ & $<.006$ & $<.003$ & $<.007$ & $<.003$ & $<.010$ & $<.004$ & $<.022$ & $<.011$ & $<.01$ & $<.004$ & $<.025$ \\
\hline$\underset{\text { JAN }}{08} \cdots$ & -- & -- & -- & -- & -- & -- & -- & -- & -- & -- & -- & -- & -- \\
\hline$\underset{\text { MAR }}{04 \ldots}$ & $<.015$ & $<.006$ & $<.006$ & $<.003$ & $<.007$ & $<.003$ & $<.010$ & $<.004$ & $<.022$ & $<.011$ & $<.01$ & $<.004$ & $<.025$ \\
\hline $\begin{array}{l}09 \\
A P R\end{array}$ & -- & -- & -- & -- & -- & -- & -- & -- & -- & -- & -- & -- & -- \\
\hline${ }_{\text {JUN }}^{13} \ldots$ & -- & -- & -- & -- & -- & -- & -- & -- & -- & -- & -- & -- & -- \\
\hline $\begin{array}{l}02 \ldots \\
\text { JUL }\end{array}$ & $<.015$ & E.005n & $<.006$ & $<.010$ & $<.007$ & $<.003$ & $<.010$ & $<.004$ & $<.022$ & $<.011$ & .01 & $<.004$ & $<.025$ \\
\hline $\begin{array}{c}13 \ldots \\
\text { AUG } \\
24 \ldots\end{array}$ & $\begin{array}{c}-- \\
<.015\end{array}$ & $<.006$ & $<.006$ & $<.003$ & $\begin{array}{c}-- \\
<.007\end{array}$ & $\begin{array}{c}-- \\
<.003\end{array}$ & $\begin{array}{c}-- \\
<.010\end{array}$ & $\begin{array}{c}-- \\
<.004\end{array}$ & $<.022$ & $\begin{array}{c}-- \\
<.011\end{array}$ & $\begin{array}{c}-- \\
\text { E.01n }\end{array}$ & $\begin{array}{c}-- \\
<.004\end{array}$ & $\begin{array}{c}-- \\
<.025\end{array}$ \\
\hline
\end{tabular}


50 Water-Quality, Sediment-Quality, Stream-Habitat, and Biological Data for Mustang Bayou, Texas, 2004-05

Appendix 1. Periodically collected water-quality properties and constituents at six sites in Mustang Bayou near Houston, Texas, September 2004-August 2005-Continued.

08077877 Mustang Bayou at Evergreen Road near Fresno, TX (M6)--Continued

WATER-QUALITY DATA, SEPTEMBER 2004 TO AUGUST 2005

\begin{tabular}{|c|c|c|c|c|c|c|c|c|c|}
\hline Date & $\begin{array}{c}\text { Pro- } \\
\text { panil, } \\
\text { water, } \\
\text { fltrd } \\
\text { ug/L }\end{array}$ & $\begin{array}{c}\text { Propar- } \\
\text { gite, } \\
\text { water, } \\
\text { fltrd } \\
\text { ug/L }\end{array}$ & $\begin{array}{c}\text { Sima- } \\
\text { zine, } \\
\text { water, } \\
\text { fltrd } \\
\text { ug/L }\end{array}$ & $\begin{array}{l}\text { Tebu- } \\
\text { thiuron, } \\
\text { water, } \\
\text { fltrd } \\
\text { ug/L }\end{array}$ & $\begin{array}{c}\text { Terbu- } \\
\text { cil, } \\
\text { water, } \\
\text { fltrd } \\
\text { ug/L }\end{array}$ & $\begin{array}{l}\text { Terbu- } \\
\text { fos, } \\
\text { water, } \\
\text { fltrd } \\
\text { ug/L }\end{array}$ & $\begin{array}{c}\text { Thio- } \\
\text { bencarb, } \\
\text { water, } \\
\text { fltrd } \\
\text { ug/L }\end{array}$ & $\begin{array}{l}\text { Tri- } \\
\text { allate, } \\
\text { water, } \\
\text { fltrd } \\
\text { ug/L }\end{array}$ & $\begin{array}{l}\text { Tri- } \\
\text { flur- } \\
\text { alin, } \\
\text { water, } \\
\text { fltrd } \\
\text { ug/L }\end{array}$ \\
\hline SEP & & & & & & & & & \\
\hline$\stackrel{14 \ldots}{\text { NOV }}$ & $<.011$ & $<.02$ & $<.005$ & $<.02$ & $<.034$ & $<.02$ & $<.010$ & $<.002$ & $<.009$ \\
\hline$\underset{\text { JAN }}{08 \ldots}$ & -- & -- & -- & -- & -- & -- & -- & -- & -- \\
\hline $\begin{array}{c}04 \\
\operatorname{MAR}\end{array}$ & $<.011$ & $<.02$ & .015 & $<.02$ & $<.034$ & $<.02$ & $<.010$ & $<.006$ & $<.009$ \\
\hline$\underset{A P R}{09 \ldots}$ & -- & -- & -- & -- & -- & -- & -- & -- & -- \\
\hline$\underset{\text { JUN }}{13 \ldots}$ & -- & -- & -- & -- & -- & -- & -- & -- & -- \\
\hline$\underset{\text { JUL }}{02 \ldots}$ & $<.011$ & $<.02$ & .028 & $<.02$ & $<.034 \mathrm{mc}$ & $<.02$ & $<.010$ & $<.006$ & $<.009$ \\
\hline$\underset{\text { AUG }}{13} \ldots$ & -- & -- & -- & -- & -- & -- & -- & -- & -- \\
\hline $24 \ldots$ & $<.011$ & $<.02$ & $<.005$ & $<.02$ & $<.034 \mathrm{mc}$ & $<.02$ & $<.010$ & $<.006$ & $<.009$ \\
\hline
\end{tabular}

\footnotetext{
Remark codes used in this table:

$<--$ Less than.

E -- Estimated.

Value qualifier codes used in this table:

c -- See laboratory comment

d -- Diluted sample: method hi range exceeded

k -- Counts outside acceptable range

m -- Value is highly variable by this method

$n$-- Below the LRL and above the LT-MDL

$t$-- Below the long-term MDI

w -- High variability: questionable precision
} 


\section{Appendix 2-Quality-Control Data}


Blank Page 
Appendix 2. Quality-control ( $\mathrm{QC}$ ) data associated with periodically collected water-quality samples from Mustang Bayou near Houston, Texas, September 2004-August, 2005.

[mg/L, milligrams per liter; fltrd (flt), filtered; N, nitrogen; unfltrd (usf), unfiltered; P, phosphorus; ug/L, micrograms per liter; cfs, cubic feet per second; deg C, degrees Celsius; mm, millimeters; Hg, mercury; mg/L, milligrams per liter; us/cm, microsiemens per centimeter; inc tit, incremental titration; $\mathrm{CaCO}_{3}$, calcium carbonate; Pt-Co, Platinum-Cobalt; NTRU, nephelometric turbidity ratio units; BOD, biochemical oxygen demand; CBOD, carbonaceous biochemical oxygen demand; MF, membrane filtration; col/100 mL, colonies per 100 milliliters; org-N, organic nitrogen; --, property or constituent not analyzed for in this sample]

\begin{tabular}{|c|c|c|c|c|c|c|c|c|c|c|c|c|}
\hline Station & & Sta & ation name & & & \multicolumn{2}{|c|}{ Date } & Time & $\begin{array}{c}\text { water, } \\
\text { fltrd, } \\
\mathrm{mg} / \mathrm{L}\end{array}$ & $\begin{array}{c}\text { water, } \\
\text { fltrd, } \\
\mathrm{mg} / \mathrm{L}\end{array}$ & $\begin{array}{c}\text { solved, } \\
\text { wat flt } \\
\mathrm{mg} / \mathrm{L}\end{array}$ & $\begin{array}{c}\text { unfltrd } \\
\mathrm{mg} / \mathrm{L} \\
\text { as N }\end{array}$ \\
\hline 08077877 & Mustang & Bayou at & Evergreen & $\mathrm{Rd} \mathrm{nr}$ Fre & sno, TX & 07 & $13-05$ & 0850 & $<.20$ & $<.2$ & $<10$ & $<.10$ \\
\hline Station & number & Date & $\begin{array}{c}\text { Ammonia } \\
\text { water, } \\
\text { unfltrd } \\
\text { mg/L } \\
\text { as N }\end{array}$ & $\begin{array}{c}\text { Nitrite } \\
+ \\
\text { nitrate } \\
\text { water } \\
\text { fltrd, } \\
\text { mg/L } \\
\text { as N }\end{array}$ & $\begin{array}{c}\text { Nitrite } \\
\text { water, } \\
\text { fltrd, } \\
\text { mg/L } \\
\text { as N }\end{array}$ & $\begin{array}{l}\text { Ortho- } \\
\text { phos- } \\
\text { phate, } \\
\text { water, } \\
\text { fltrd, } \\
\mathrm{mg} / \mathrm{L} \\
\text { as P }\end{array}$ & $\begin{array}{c}\text { Phos- } \\
\text { phorus, } \\
\text { water, } \\
\text { unfltrd } \\
\text { mg/L }\end{array}$ & $\begin{array}{c}\text { Pheo- } \\
\text { phytin } \\
\text { a, } \\
\text { phyto- } \\
\text { plank- } \\
\text { ton, } \\
\text { ug/L }\end{array}$ & $\begin{array}{c}\text { Chloro- } \\
\text { phyll a } \\
\text { phyto- } \\
\text { plank- } \\
\text { ton, } \\
\text { fluoro, } \\
\text { ug/L }\end{array}$ & & & \\
\hline 0807 & 7877 & $07-13-05$ & $<.04$ & $<.016$ & $<.002$ & $<.006$ & $<.04$ & $<.03$ & $<.03$ & & & \\
\hline
\end{tabular}

MATRIX SPIKE DATA

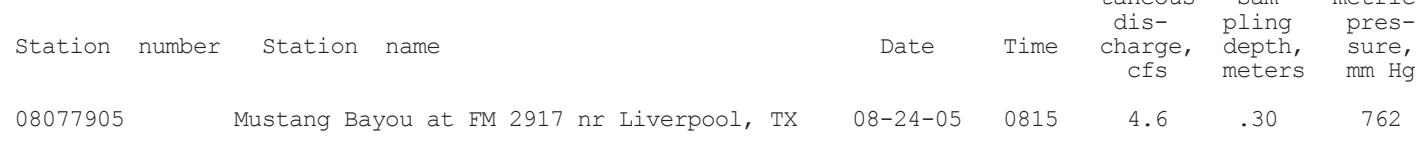

\begin{tabular}{|c|c|c|c|c|c|c|c|c|c|c|c|}
\hline $\begin{array}{l}\text { Dis- } \\
\text { solved } \\
\text { oxygen, } \\
\text { mg/L }\end{array}$ & $\begin{array}{l}\text { Dis- } \\
\text { solved } \\
\text { oxygen, } \\
\text { percent } \\
\text { of sat- } \\
\text { uration }\end{array}$ & $\begin{array}{l}\text { pH, } \\
\text { water, } \\
\text { unfltrd } \\
\text { field, } \\
\text { std } \\
\text { units }\end{array}$ & $\begin{array}{l}\text { Specil } \\
\text { conduc } \\
\text { tance, } \\
\text { wat ur } \\
\text { us / cm } \\
25 \mathrm{deg}\end{array}$ & & $\begin{array}{l}\text { Temper- } \\
\text { ature, } \\
\text { air, } \\
\text { deg } C\end{array}$ & $\begin{array}{l}\text { Temper- } \\
\text { ature, } \\
\text { water, } \\
\text { deg C }\end{array}$ & $\begin{array}{l}\text { 2,6-Di- } \\
\text { ethyl- } \\
\text { aniline } \\
\text { water } \\
\text { fltrd } \\
0.7 \mathrm{u} \text { GF } \\
\mathrm{ug} / \mathrm{L}\end{array}$ & $\begin{array}{c}\text { Aceto- } \\
\text { chlor, } \\
\text { water, } \\
\text { fltrd, } \\
\text { ug/L }\end{array}$ & $\begin{array}{l}\text { alpha- } \\
\text { HCH, } \\
\text { water, } \\
\text { fltrd, } \\
\text { ug/L }\end{array}$ & $\begin{array}{c}\text { Ala- } \\
\text { chlor, } \\
\text { water, } \\
\text { fltrd } \\
\text { ug/L }\end{array}$ & $\begin{array}{l}\text { Atra- } \\
\text { zine, } \\
\text { water, } \\
\text { fltrd, } \\
\text { ug/L }\end{array}$ \\
\hline .4 & 6 & 7.1 & 846 & & 28.5 & 29.9 & .090 & .144 & .131 & .134 & .255 \\
\hline $\begin{array}{c}\text { CIAT, } \\
\text { water, } \\
\text { fltrd } \\
\text { ug/I }\end{array}$ & $\begin{array}{l}\text { Azin- } \\
\text { phos- } \\
\text { methyl, } \\
\text { water, } \\
\text { fltrd } \\
\text { ug/L }\end{array}$ & $\begin{array}{l}\text { Ben- } \\
\text { flur- } \\
\text { alin, } \\
\text { water, } \\
\text { fltrd } \\
\text { ug/L }\end{array}$ & $\begin{array}{l}\text { Butyl- } \\
\text { ate, } \\
\text { water, } \\
\text { fltrd } \\
\text { ug/L }\end{array}$ & $\begin{array}{c}\text { Car- } \\
\text { baryl, } \\
\text { water, } \\
\text { fltrd } \\
\text { ug/L }\end{array}$ & $\begin{array}{l}\text { Carbo- } \\
\text { furan, } \\
\text { water, } \\
\text { fltrd } \\
\text { ug/L }\end{array}$ & $\begin{array}{c}\text { Chlor- } \\
\text { pyrifos } \\
\text { water, } \\
\text { fltrd } \\
\text { ug/L }\end{array}$ & $\begin{array}{l}\text { cis- } \\
\text { Per- } \\
\text { methrin, } \\
\text { water, } \\
\text { fltrd } \\
\text { ug/L }\end{array}$ & $\begin{array}{l}\text { Cyana- } \\
\text { zine, } \\
\text { water, } \\
\text { fltrd } \\
\text { ug/L }\end{array}$ & $\begin{array}{l}\text { DCPA, } \\
\text { water, } \\
\text { fltrd } \\
\text { ug/L }\end{array}$ & $\begin{array}{l}\text { Desulf- } \\
\text { inyl } \\
\text { fipro- } \\
\text { nil, } \\
\text { water, } \\
\text { fltrd, } \\
\text { ug/L }\end{array}$ & $\begin{array}{l}\text { Diazi- } \\
\text { non, } \\
\text { water, } \\
\text { fltrd } \\
\text { ug/L }\end{array}$ \\
\hline E.037 & E.096 & .097 & .120 & E.105 & E.098 & .110 & .046 & .096 & .138 & .137 & .139 \\
\hline
\end{tabular}




\section{Water-Quality, Sediment-Quality, Stream-Habitat, and Biological Data for Mustang Bayou, Texas, 2004-05}

Appendix 2. Quality-control ( $\mathrm{OC})$ data associated with periodically collected water-quality samples from Mustang Bayou near Houston, Texas, September 2004-August, 2005-Continued.

MATRIX SPIKE DATA--Continued

\begin{tabular}{|c|c|c|c|c|c|c|c|c|c|c|c|c|}
\hline $\begin{array}{l}\text { Diel- } \\
\text { drin, } \\
\text { water, } \\
\text { fltrd, } \\
\text { ug/L }\end{array}$ & $\begin{array}{l}\text { Disul- } \\
\text { foton, } \\
\text { water, } \\
\text { fltrd } \\
\text { ug/L }\end{array}$ & $\begin{array}{c}\text { EPTC, } \\
\text { water, } \\
\text { fltrd } \\
\text { ug/L }\end{array}$ & $\begin{array}{l}\text { Ethal- } \\
\text { flur- } \\
\text { alin, } \\
\text { water, } \\
\text { fltrd } \\
\text { ug/L }\end{array}$ & $\begin{array}{l}\text { Etho- } \\
\text { prop, } \\
\text { water, } \\
\text { fltrd } \\
\text { ug/L }\end{array}$ & $\begin{array}{c}\text { Desulf- } \\
\text { inyl- } \\
\text { fipro- } \\
\text { nil } \\
\text { amide, } \\
\text { wat flt } \\
\text { ug/L }\end{array}$ & $\begin{array}{c}\text { Fipro- } \\
\text { nil } \\
\text { sulfide } \\
\text { water, } \\
\text { fltrd } \\
\text { ug/L }\end{array}$ & $\begin{array}{l}\text { Fipro- } \\
\text { nil } \\
\text { sulfone } \\
\text { water, } \\
\text { fltrd } \\
\text { ug/L }\end{array}$ & $\begin{array}{c}\text { Desulf- } \\
\text { inyl } \\
\text { fipro- } \\
\text { nil, } \\
\text { water, } \\
\text { fltrd } \\
\text { ug/L }\end{array}$ & $\begin{array}{c}\text { Fipro- } \\
\text { nil, } \\
\text { water, } \\
\text { fltrd } \\
\text { ug/L }\end{array}$ & $\begin{array}{c}\text { Fonofos } \\
\text { water, } \\
\text { fltrd } \\
\text { ug/L }\end{array}$ & $\begin{array}{c}\text { Lindane } \\
\text { water, } \\
\text { fltrd } \\
\text { ug/L }\end{array}$ & $\begin{array}{c}\text { Linuron } \\
\text { water, } \\
\text { fltrd } \\
\text { ug/L }\end{array}$ \\
\hline .146 & E.09 & .099 & .099 & .101 & E.070 & .137 & .109 & .137 & E. 148 & .119 & .131 & .156 \\
\hline $\begin{array}{l}\text { Mala- } \\
\text { thion, } \\
\text { water, } \\
\text { fltrd } \\
\text { ug/L }\end{array}$ & $\begin{array}{l}\text { Methyl } \\
\text { para- } \\
\text { thion, } \\
\text { water, } \\
\text { fltrd } \\
\text { ug/L }\end{array}$ & $\begin{array}{c}\text { Metola- } \\
\text { chlor, } \\
\text { water, } \\
\text { fltrd } \\
\text { ug/L }\end{array}$ & $\begin{array}{l}\text { Metri- } \\
\text { buzin, } \\
\text { water, } \\
\text { fltrd } \\
\text { ug/L }\end{array}$ & $\begin{array}{l}\text { Moli- } \\
\text { nate, } \\
\text { water, } \\
\text { fltrd } \\
\text { ug/L }\end{array}$ & $\begin{array}{c}\text { Naprop- } \\
\text { amide, } \\
\text { water, } \\
\text { fltrd } \\
\text { ug/L }\end{array}$ & $\begin{array}{l}\mathrm{p}, \mathrm{p}^{\prime}- \\
\mathrm{DDE}, \\
\text { water, } \\
\text { fltrd } \\
\text { ug/L }\end{array}$ & $\begin{array}{l}\text { Para- } \\
\text { thion, } \\
\text { water, } \\
\text { fltrd } \\
\text { ug/L }\end{array}$ & $\begin{array}{l}\text { Peb- } \\
\text { ulate, } \\
\text { water, } \\
\text { fltrd } \\
\text { ug/L }\end{array}$ & $\begin{array}{l}\text { Pendi- } \\
\text { meth- } \\
\text { alin, } \\
\text { water, } \\
\text { fltrd } \\
\text { ug/L }\end{array}$ & $\begin{array}{c}\text { Phorate, } \\
\text { water, } \\
\text { fltrd } \\
\text { ug/L }\end{array}$ & $\begin{array}{l}\text { Prome- } \\
\text { ton, } \\
\text { water, } \\
\text { fltrd } \\
\text { ug/L }\end{array}$ & $\begin{array}{l}\text { Propy- } \\
\text { zamide, } \\
\text { water, } \\
\text { fltrd } \\
\text { ug/L }\end{array}$ \\
\hline .108 & .151 & .128 & .084 & .102 & .131 & .068 & .145 & .106 & .107 & .100 & .12 & .130 \\
\hline
\end{tabular}

\begin{tabular}{|c|c|c|c|c|c|c|c|c|c|}
\hline $\begin{array}{l}\text { Propa- } \\
\text { chlor, } \\
\text { water, } \\
\text { fltrd } \\
\text { ug/L }\end{array}$ & $\begin{array}{c}\text { Pro- } \\
\text { panil, } \\
\text { water, } \\
\text { fltrd } \\
\text { ug/L }\end{array}$ & $\begin{array}{l}\text { Propar- } \\
\text { gite, } \\
\text { water, } \\
\text { fltrd } \\
\text { ug/L }\end{array}$ & $\begin{array}{c}\text { Sima- } \\
\text { zine, } \\
\text { water, } \\
\text { ug/L }\end{array}$ & $\begin{array}{l}\text { Tebu- } \\
\text { thiuron } \\
\text { water } \\
\text { fltrd } \\
\text { ug/L }\end{array}$ & $\begin{array}{c}\text { Terba- } \\
\text { cil, } \\
\text { water, } \\
\text { fltrd } \\
\text { ug/L }\end{array}$ & $\begin{array}{c}\text { Terbu- } \\
\text { fos, } \\
\text { water, } \\
\text { fltrd } \\
\text { ug/L }\end{array}$ & $\begin{array}{c}\text { Thio- } \\
\text { bencarb } \\
\text { water } \\
\text { fltrd } \\
\text { ug/L }\end{array}$ & $\begin{array}{c}\text { Tri- } \\
\text { allate, } \\
\text { water, } \\
\text { fltrd } \\
\text { ug/L }\end{array}$ & $\begin{array}{l}\text { Tri- } \\
\text { flur- } \\
\text { alin, } \\
\text { water, } \\
\text { fltrd } \\
\text { ug/L }\end{array}$ \\
\hline .130 & .117 & .11 & .112 & .12 & E.060 & .10 & .133 & .125 & 96 \\
\hline
\end{tabular}

SPLIT REPLICATE DATA

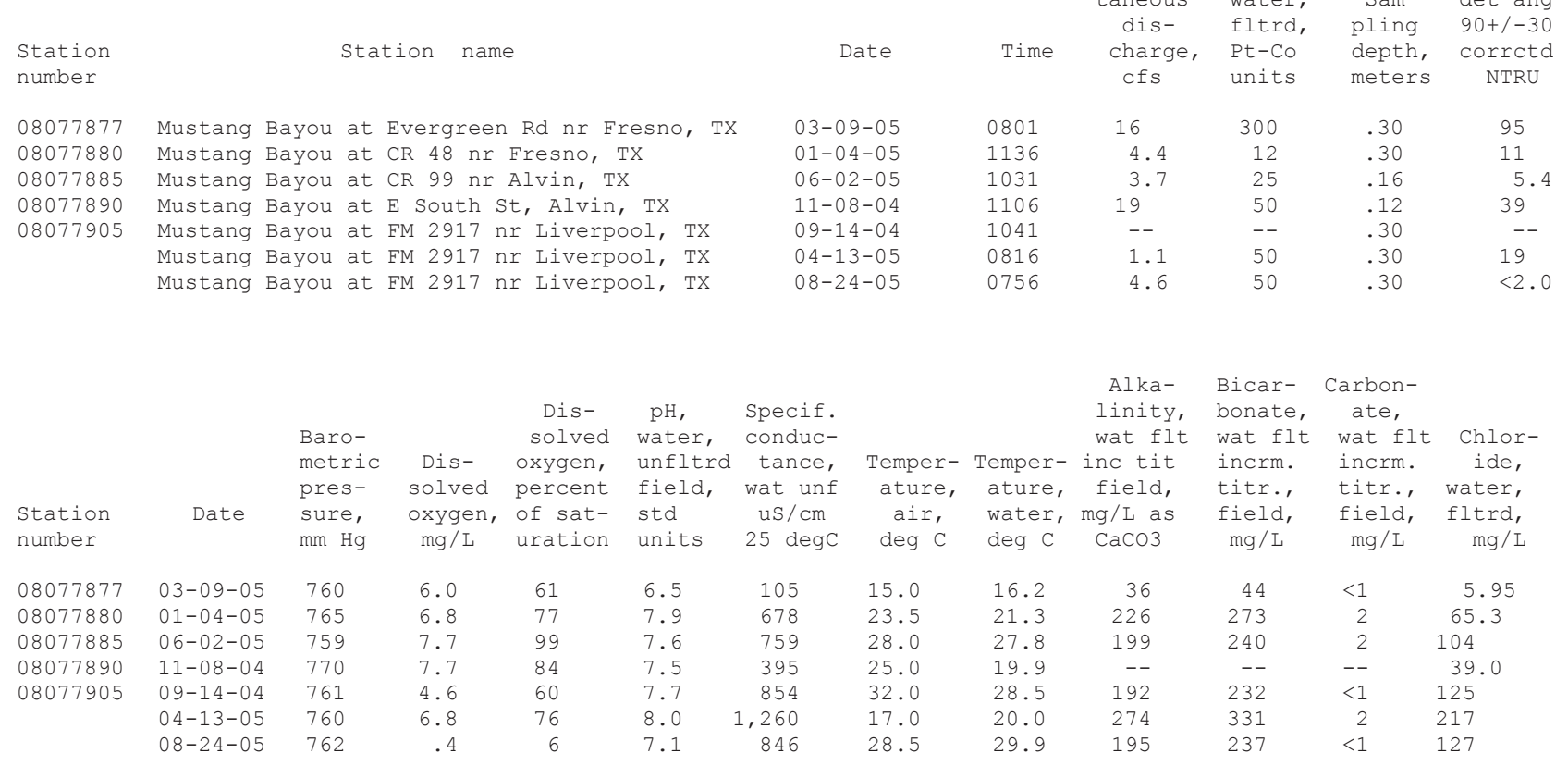


Appendix 2. Quality-control ( $\mathrm{QC}$ ) data associated with periodically collected water-quality samples from Mustang Bayou near Houston, Texas, September 2004-August, 2005-Continued.

SPLIT REPLICATE DATA--Continued

\begin{tabular}{|c|c|c|c|c|c|c|c|c|c|c|c|c|}
\hline $\begin{array}{l}\text { Station } \\
\text { number }\end{array}$ & Date & $\begin{array}{l}\text { Sulfate } \\
\text { water, } \\
\text { fltrd } \\
\mathrm{mg} / \mathrm{L}\end{array}$ & $\begin{array}{l}\text { Solids, } \\
\quad \text { dis- } \\
\text { solved, } \\
\text { fltrd } \\
\mathrm{mg} / \mathrm{L}\end{array}$ & $\begin{array}{l}\text { Solids, } \\
\text { total, } \\
\text { sus- } \\
\text { pended } \\
\text { mg/L }\end{array}$ & $\begin{array}{c}\text { Ammonia } \\
\quad+ \\
\text { org-N, } \\
\text { water, } \\
\text { unfltrd } \\
\text { mg/L } \\
\text { as N }\end{array}$ & $\begin{array}{c}\text { Ammonia } \\
\text { water, } \\
\text { unfltrd } \\
\text { mg/L } \\
\text { as N }\end{array}$ & $\begin{array}{l}\text { Nitrate } \\
\text { water, } \\
\text { fltrd } \\
\mathrm{mg} / \mathrm{L} \\
\text { as N }\end{array}$ & $\begin{array}{l}\text { Nitrite } \\
+ \\
\text { nitrate } \\
\text { water, } \\
\text { fltrd } \\
\mathrm{mg} / \mathrm{L} \\
\text { as N }\end{array}$ & $\begin{array}{c}\text { Nitrite } \\
\text { water, } \\
\text { fltrd } \\
\mathrm{mg} / \mathrm{L} \\
\text { as N }\end{array}$ & $\begin{array}{c}\text { Organic } \\
\text { nitro- } \\
\text { gen, } \\
\text { water, } \\
\text { unfltrd } \\
\mathrm{mg} / \mathrm{L}\end{array}$ & $\begin{array}{l}\text { Total } \\
\text { nitro- } \\
\text { gen, } \\
\text { water, } \\
\text { unfltrd } \\
\text { mg/L }\end{array}$ & $\begin{array}{l}\text { Ortho } \\
\text { phos- } \\
\text { phate } \\
\text { water } \\
\text { fltrd } \\
\mathrm{mg} / \mathrm{L} \\
\text { as P }\end{array}$ \\
\hline $\begin{array}{l}08077877 \\
08077880 \\
08077885 \\
08077890 \\
08077905\end{array}$ & $\begin{array}{l}03-09-05 \\
01-04-05 \\
06-02-05 \\
11-08-04 \\
09-14-04 \\
04-13-05 \\
08-24-05\end{array}$ & $\begin{array}{r}2.7 \\
19.8 \\
19.5 \\
12.9 \\
25.4 \\
29.4 \\
23.5\end{array}$ & $\begin{array}{r}87 \\
395 \\
423 \\
228 \\
479 \\
695 \\
487\end{array}$ & $\begin{array}{r}42 \\
25 \\
<10 \\
36 \\
-- \\
20 \\
<10\end{array}$ & $\begin{array}{l}1.4 \\
.18 \\
.28 \\
.57 \\
.67 \\
.41 \\
.70\end{array}$ & $\begin{array}{r}.10 \\
.04 \\
<.04 \\
.05 \\
.03 \\
.03 \\
\text { E.04 }\end{array}$ & $\begin{array}{l}.04 \\
.13 \\
-- \\
.09 \\
.33 \\
.01 \\
.17\end{array}$ & $\begin{array}{r}.050 \\
.132 \\
<.016 \\
.094 \\
.342 \\
.059 \\
.203\end{array}$ & $\begin{array}{r}.007 \\
.005 \\
<.002 \\
.008 \\
.015 \\
.044 \\
.034\end{array}$ & $\begin{array}{l}1.3 \\
.14 \\
-- \\
.52 \\
.63 \\
.39 \\
--\end{array}$ & $\begin{array}{c}1.5 \\
.31 \\
-- \\
.66 \\
1.0 \\
.47 \\
.90\end{array}$ & $\begin{array}{l}.031 \\
.029 \\
.054 \\
.067 \\
.240 \\
.229 \\
.160\end{array}$ \\
\hline
\end{tabular}

\begin{tabular}{|c|c|c|c|c|c|c|c|c|c|c|c|c|}
\hline $\begin{array}{l}\text { Station } \\
\text { number }\end{array}$ & Date & $\begin{array}{l}\text { Phos- } \\
\text { phorus, } \\
\text { water, } \\
\text { unfltrd } \\
\text { mg/L }\end{array}$ & $\begin{array}{c}\text { BOD, } \\
\text { water, } \\
\text { unfltrd } \\
5 \text { day, } \\
20 \text { degC } \\
\mathrm{mg} / \mathrm{L}\end{array}$ & $\begin{array}{c}\text { CBOD, } \\
\text { water, } \\
\text { unfltrd } \\
5 \text { day, } \\
\text { mg/L }\end{array}$ & $\begin{array}{c}\text { Pheo- } \\
\text { phytin } \\
\text { a, } \\
\text { phyto- } \\
\text { plank- } \\
\text { ton, } \\
\text { ug/L }\end{array}$ & $\begin{array}{c}\text { E coli, } \\
\text { m-TEC } \\
\text { MF, } \\
\text { water, } \\
\text { col/ } \\
100 \mathrm{~mL}\end{array}$ & $\begin{array}{l}\text { Chloro- } \\
\text { phyll a } \\
\text { phyto- } \\
\text { plank- } \\
\text { ton, } \\
\text { fluoro, } \\
\text { ug/L }\end{array}$ & $\begin{array}{l}\text { 2,6-Di- } \\
\text { ethyl- } \\
\text { aniline } \\
\text { water } \\
\text { fltrd } \\
0.7 \mathrm{u} \mathrm{GF} \\
\mathrm{ug} / \mathrm{L}\end{array}$ & $\begin{array}{l}\text { CIAT, } \\
\text { water, } \\
\text { fltrd, } \\
\text { ug/L }\end{array}$ & $\begin{array}{l}\text { Aceto- } \\
\text { chlor, } \\
\text { water, } \\
\text { fltrd, } \\
\text { ug/L }\end{array}$ & $\begin{array}{l}\text { Ala- } \\
\text { chlor, } \\
\text { water, } \\
\text { fltrd, } \\
\text { ug/L }\end{array}$ & $\begin{array}{l}\text { alpha- } \\
\text { HCH, } \\
\text { water, } \\
\text { fltrd, } \\
\text { ug/L }\end{array}$ \\
\hline 08077877 & $03-09-05$ & .15 & 3.7 & 2.8 & 3.7 & 3,500 & 1.2 & -- & -- & -- & -- & -- \\
\hline 08077880 & $01-04-05$ & E.04 & 1.3 & 1.1 & 1.4 & -- & 1.9 & $<.006$ & $<.006$ & $<.006$ & $<.005$ & $<.005$ \\
\hline 08077885 & $06-02-05$ & .08 & .8 & .5 & 1.3 & $<7$ & 1.1 & $<.006$ & E.026 & $<.006$ & $<.005$ & $<.005$ \\
\hline 08077890 & $01-08-04$ & .13 & 2.3 & 2.1 & 1.5 & 140 & .8 & -- & -- & -- & -- & -- \\
\hline 08077905 & $09-14-04$ & .27 & 3.0 & -- & 3.7 & 620 & 6.7 & $<.006$ & E.015 & $<.006$ & $<.005$ & $<.005$ \\
\hline & $04-13-05$ & .27 & E. 7 & $\mathrm{E} 1.4$ & 1.2 & E120 & 3.3 & -- & -- & -- & -- & -- \\
\hline & $08-24-05$ & .19 & 2.2 & 2.1 & 1.9 & E120 & 1.9 & -- & -- & -- & -- & -- \\
\hline
\end{tabular}

\begin{tabular}{|c|c|c|c|c|c|c|c|c|c|c|c|c|}
\hline $\begin{array}{l}\text { Station } \\
\text { number }\end{array}$ & Date & $\begin{array}{l}\text { Atra- } \\
\text { zine, } \\
\text { water, } \\
\text { fltrd, } \\
\text { ug/L }\end{array}$ & $\begin{array}{c}\text { Azin- } \\
\text { phos- } \\
\text { methyl, } \\
\text { water, } \\
\text { fltrd } \\
0.7 \mathrm{u} \mathrm{GF} \\
\mathrm{ug} / \mathrm{L}\end{array}$ & $\begin{array}{l}\text { Ben- } \\
\text { flur- } \\
\text { alin, } \\
\text { water, } \\
\text { fltrd } \\
0.7 \mathrm{u} \mathrm{GF} \\
\mathrm{ug} / \mathrm{L}\end{array}$ & $\begin{array}{l}\text { Butyl- } \\
\text { ate, } \\
\text { water, } \\
\text { fltrd, c } \\
\text { ug/L }\end{array}$ & $\begin{array}{c}\text { Car- } \\
\text { baryl, } \\
\text { water, } \\
\text { fltrd } \\
0.7 \mathrm{u} \mathrm{GF} \\
\text { ug/L }\end{array}$ & $\begin{array}{l}\text { Carbo- } \\
\text { furan, } \\
\text { water, p } \\
\text { fltrd } \\
0.7 \mathrm{u} \text { GF } \\
\text { ug/L }\end{array}$ & $\begin{array}{l}\text { Chlor- } \\
\text { pyrifos } \\
\text { water, } \\
\text { fltrd, } \\
\text { ug/L }\end{array}$ & $\begin{array}{l}\text { Cis- } \\
\text { Per- } \\
\text { methrin } \\
\text { water } \\
\text { fltrd } \\
0.7 \mathrm{u} \mathrm{GF} \\
\text { ug/L }\end{array}$ & $\begin{array}{l}\text { Cyana- } \\
\text { zine, } \\
\text { water, } \\
\text { fltrd, } 0 . \\
\text { ug/L }\end{array}$ & $\begin{array}{c}\text { DCPA, } \\
\text { water } \\
\text { fltrd } \\
0.7 \mathrm{u} \mathrm{GF} \\
\mathrm{ug} / \mathrm{L}\end{array}$ & $\begin{array}{l}\text { Desulf- } \\
\text { inyl } \\
\text { fipro- } \\
\text { nil, } \\
\text { water, } \\
\text { fltrd, } \\
\text { ug/L }\end{array}$ \\
\hline 08077877 & $03-09-05$ & -- & -- & -- & -- & -- & -- & -- & -- & -- & -- & -- \\
\hline 08077880 & $01-04-05$ & .011 & $<.050$ & $<.010$ & $<.004$ & $<.041$ & $<.020$ & $<.005$ & $<.006$ & $<.018$ & $<.003$ & $<.012$ \\
\hline 08077890 & $11-08-04$ & -- & -- & -- & -- & -- & -- & -- & -- & -- & -- & -- \\
\hline 08077905 & $\begin{array}{l}09-14-04 \\
04-13-05 \\
08-24-05\end{array}$ & $\begin{array}{l}.084 \\
-- \\
--\end{array}$ & $\begin{array}{l}<.050 \\
-- \\
--\end{array}$ & $\begin{array}{c}<.010 \\
-- \\
--\end{array}$ & $\begin{array}{c}<.004 \\
-- \\
--\end{array}$ & $\begin{array}{c}<.041 \\
-- \\
--\end{array}$ & $\begin{array}{c}<.020 \\
-- \\
--\end{array}$ & $\begin{array}{c}<.005 \\
-- \\
--\end{array}$ & $\begin{array}{c}<.006 \\
-- \\
--\end{array}$ & $\begin{array}{c}<.018 \\
-- \\
--\end{array}$ & $\begin{array}{c}<.003 \\
-- \\
--\end{array}$ & $\begin{array}{c}\text { E. } 006 \\
-- \\
--\end{array}$ \\
\hline $\begin{array}{l}\text { Station } \\
\text { number }\end{array}$ & Date & $\begin{array}{l}\text { Diazi- } \\
\text { non, } \\
\text { water, } \\
\text { fltrd, } \\
\text { ug/L }\end{array}$ & $\begin{array}{l}\text { Diel- } \\
\text { drin, } \\
\text { water, } \\
\text { fltrd, } \\
\text { ug/L }\end{array}$ & $\begin{array}{l}\text { Disul- } \\
\text { foton, } \\
\text { water, } \\
\text { fltrd } \\
0.7 \mathrm{u} \mathrm{GF} \\
\text { ug/L }\end{array}$ & $\begin{array}{c}\text { EPTC, } \\
\text { water, } \\
\text { fltrd } \\
0.7 \text { u GF } \\
\text { ug/L }\end{array}$ & $\begin{array}{c}\text { Ethal- } \\
\text { flur- } \\
\text { alin, } \\
\text { water, } \\
\text { fltrd } \\
0.7 \mathrm{G} \text { GF } \\
\text { ug/L }\end{array}$ & $\begin{array}{l}\text { Etho- } \\
\text { prop, } \\
\text { water, } \\
\text { fltrd } \\
0.7 \mathrm{u} \text { GF } \\
\mathrm{ug} / \mathrm{L}\end{array}$ & $\begin{array}{l}\text { Desulf- } \\
\text { inyl- } \\
\text { fipro- } \\
\text { nil } \\
\text { amide, } \\
\text { F wat flt } \\
\text { ug/L }\end{array}$ & $\begin{array}{c}\text { Fipro- } \\
\text { nil } \\
\text { sulfide } \\
\text { water, } \\
\text { tltrd, } \\
\text { ug/L }\end{array}$ & $\begin{array}{c}\text { Fipro- } \\
\text { nil } \\
\text { sulfone } \\
\text { water, } \\
\text { fltrd, } \\
\text { ug/L }\end{array}$ & $\begin{array}{c}\text { Fipro- } \\
\text { e nil, } \\
\text {, water, } \\
\text { d, fltrd, } \\
\text { ug/L }\end{array}$ & $\begin{array}{c}\text { Fonofos } \\
\text { water, } \\
\text { fltrd, } \\
\text { ug/L }\end{array}$ \\
\hline 08077877 & $03-09-05$ & -- & -- & -- & -- & -- & -- & -- & -- & -- & -- & -- \\
\hline 08077880 & $01-04-05$ & $<.005$ & $<.009$ & $<.02$ & $<.004$ & $<.009$ & $<.005$ & $<.029$ & $<.013$ & $<.024$ & $<.016$ & $<.003$ \\
\hline 08077885 & $06-02-05$ & $<.005$ & $<.009$ & $<.02$ & $<.004$ & $<.009$ & $<.005$ & $<.029$ & $<.013$ & $<.024$ & $<.016$ & $<.003$ \\
\hline 08077890 & $11-08-04$ & -- & -- & -- & -- & -- & -- & -- & -- & -- & -- & -- \\
\hline 08077905 & $\begin{array}{l}09-14-04 \\
04-13-05 \\
08-24-05\end{array}$ & $\begin{array}{c}<.005 \\
-- \\
--\end{array}$ & $\begin{array}{c}<.009 \\
-- \\
--\end{array}$ & $\begin{array}{c}<.02 \\
-- \\
--\end{array}$ & $\begin{array}{c}<.004 \\
-- \\
--\end{array}$ & $\begin{array}{c}<.009 \\
-- \\
--\end{array}$ & $\begin{array}{c}<.005 \\
-- \\
--\end{array}$ & $\begin{array}{c}<.029 \\
-- \\
--\end{array}$ & $\begin{array}{c}\text { E. } 009 \\
-- \\
--\end{array}$ & $\begin{array}{c}\text { E. } 011 \\
-- \\
--\end{array}$ & $\begin{array}{c}\text { E. } 005 \\
-- \\
--\end{array}$ & $\begin{array}{c}<.003 \\
-- \\
--\end{array}$ \\
\hline
\end{tabular}

\begin{tabular}{|c|c|c|c|c|c|c|c|c|c|c|c|c|}
\hline $\begin{array}{l}\text { Station } \\
\text { number }\end{array}$ & Date & $\begin{array}{l}\text { Atra- } \\
\text { zine, } \\
\text { water, } \\
\text { fltrd, } \\
\text { ug/L }\end{array}$ & $\begin{array}{c}\text { Azin- } \\
\text { phos- } \\
\text { methyl, } \\
\text { water, } \\
\text { fltrd } \\
0.7 \mathrm{u} \mathrm{GF} \\
\mathrm{ug} / \mathrm{L}\end{array}$ & $\begin{array}{l}\text { Ben- } \\
\text { flur- } \\
\text { alin, } \\
\text { water, } \\
\text { fltrd } \\
0.7 \mathrm{u} \mathrm{GF} \\
\mathrm{ug} / \mathrm{L}\end{array}$ & $\begin{array}{l}\text { Butyl- } \\
\text { ate, } \\
\text { water, } \\
\text { fltrd, c } \\
\text { ug/L }\end{array}$ & $\begin{array}{c}\text { Car- } \\
\text { baryl, } \\
\text { water, } \\
\text { fltrd } \\
0.7 \mathrm{u} \mathrm{GF} \\
\text { ug/L }\end{array}$ & $\begin{array}{l}\text { Carbo- } \\
\text { furan, } \\
\text { water, p } \\
\text { fltrd } \\
0.7 \mathrm{u} \text { GF } \\
\text { ug/L }\end{array}$ & $\begin{array}{l}\text { Chlor- } \\
\text { pyrifos } \\
\text { water, } \\
\text { fltrd, } \\
\text { ug/L }\end{array}$ & $\begin{array}{l}\text { Cis- } \\
\text { Per- } \\
\text { methrin } \\
\text { water } \\
\text { fltrd } \\
0.7 \mathrm{u} \mathrm{GF} \\
\text { ug/L }\end{array}$ & $\begin{array}{l}\text { Cyana- } \\
\text { zine, } \\
\text { water, } \\
\text { fltrd, } 0 . \\
\text { ug/L }\end{array}$ & $\begin{array}{c}\text { DCPA, } \\
\text { water } \\
\text { fltrd } \\
0.7 \mathrm{u} \mathrm{GF} \\
\mathrm{ug} / \mathrm{L}\end{array}$ & $\begin{array}{l}\text { Desulf- } \\
\text { inyl } \\
\text { fipro- } \\
\text { nil, } \\
\text { water, } \\
\text { fltrd, } \\
\text { ug/L }\end{array}$ \\
\hline 08077877 & $03-09-05$ & -- & -- & -- & -- & -- & -- & -- & -- & -- & -- & -- \\
\hline 08077880 & $01-04-05$ & .011 & $<.050$ & $<.010$ & $<.004$ & $<.041$ & $<.020$ & $<.005$ & $<.006$ & $<.018$ & $<.003$ & $<.012$ \\
\hline 08077890 & $11-08-04$ & -- & -- & -- & -- & -- & -- & -- & -- & -- & -- & -- \\
\hline 08077905 & $\begin{array}{l}09-14-04 \\
04-13-05 \\
08-24-05\end{array}$ & $\begin{array}{l}.084 \\
-- \\
--\end{array}$ & $\begin{array}{l}<.050 \\
-- \\
--\end{array}$ & $\begin{array}{c}<.010 \\
-- \\
--\end{array}$ & $\begin{array}{c}<.004 \\
-- \\
--\end{array}$ & $\begin{array}{c}<.041 \\
-- \\
--\end{array}$ & $\begin{array}{c}<.020 \\
-- \\
--\end{array}$ & $\begin{array}{c}<.005 \\
-- \\
--\end{array}$ & $\begin{array}{c}<.006 \\
-- \\
--\end{array}$ & $\begin{array}{c}<.018 \\
-- \\
--\end{array}$ & $\begin{array}{c}<.003 \\
-- \\
--\end{array}$ & $\begin{array}{c}\text { E. } 006 \\
-- \\
--\end{array}$ \\
\hline $\begin{array}{l}\text { Station } \\
\text { number }\end{array}$ & Date & $\begin{array}{l}\text { Diazi- } \\
\text { non, } \\
\text { water, } \\
\text { fltrd, } \\
\text { ug/L }\end{array}$ & $\begin{array}{l}\text { Diel- } \\
\text { drin, } \\
\text { water, } \\
\text { fltrd, } \\
\text { ug/L }\end{array}$ & $\begin{array}{l}\text { Disul- } \\
\text { foton, } \\
\text { water, } \\
\text { fltrd } \\
0.7 \mathrm{u} \mathrm{GF} \\
\text { ug/L }\end{array}$ & $\begin{array}{c}\text { EPTC, } \\
\text { water, } \\
\text { fltrd } \\
0.7 \text { u GF } \\
\text { ug/L }\end{array}$ & $\begin{array}{c}\text { Ethal- } \\
\text { flur- } \\
\text { alin, } \\
\text { water, } \\
\text { fltrd } \\
0.7 \mathrm{G} \text { GF } \\
\text { ug/L }\end{array}$ & $\begin{array}{l}\text { Etho- } \\
\text { prop, } \\
\text { water, } \\
\text { fltrd } \\
0.7 \mathrm{u} \text { GF } \\
\mathrm{ug} / \mathrm{L}\end{array}$ & $\begin{array}{l}\text { Desulf- } \\
\text { inyl- } \\
\text { fipro- } \\
\text { nil } \\
\text { amide, } \\
\text { F wat flt } \\
\text { ug/L }\end{array}$ & $\begin{array}{c}\text { Fipro- } \\
\text { nil } \\
\text { sulfide } \\
\text { water, } \\
\text { tltrd, } \\
\text { ug/L }\end{array}$ & $\begin{array}{c}\text { Fipro- } \\
\text { nil } \\
\text { sulfone } \\
\text { water, } \\
\text { fltrd, } \\
\text { ug/L }\end{array}$ & $\begin{array}{c}\text { Fipro- } \\
\text { e nil, } \\
\text {, water, } \\
\text { d, fltrd, } \\
\text { ug/L }\end{array}$ & $\begin{array}{c}\text { Fonofos } \\
\text { water, } \\
\text { fltrd, } \\
\text { ug/L }\end{array}$ \\
\hline 08077877 & $03-09-05$ & -- & -- & -- & -- & -- & -- & -- & -- & -- & -- & -- \\
\hline 08077880 & $01-04-05$ & $<.005$ & $<.009$ & $<.02$ & $<.004$ & $<.009$ & $<.005$ & $<.029$ & $<.013$ & $<.024$ & $<.016$ & $<.003$ \\
\hline 08077885 & $06-02-05$ & $<.005$ & $<.009$ & $<.02$ & $<.004$ & $<.009$ & $<.005$ & $<.029$ & $<.013$ & $<.024$ & $<.016$ & $<.003$ \\
\hline 08077890 & $11-08-04$ & -- & -- & -- & -- & -- & -- & -- & -- & -- & -- & -- \\
\hline 08077905 & $\begin{array}{l}09-14-04 \\
04-13-05 \\
08-24-05\end{array}$ & $\begin{array}{c}<.005 \\
-- \\
--\end{array}$ & $\begin{array}{c}<.009 \\
-- \\
--\end{array}$ & $\begin{array}{c}<.02 \\
-- \\
--\end{array}$ & $\begin{array}{c}<.004 \\
-- \\
--\end{array}$ & $\begin{array}{c}<.009 \\
-- \\
--\end{array}$ & $\begin{array}{c}<.005 \\
-- \\
--\end{array}$ & $\begin{array}{c}<.029 \\
-- \\
--\end{array}$ & $\begin{array}{c}\text { E. } 009 \\
-- \\
--\end{array}$ & $\begin{array}{c}\text { E. } 011 \\
-- \\
--\end{array}$ & $\begin{array}{c}\text { E. } 005 \\
-- \\
--\end{array}$ & $\begin{array}{c}<.003 \\
-- \\
--\end{array}$ \\
\hline
\end{tabular}

Station
number

08077877 08077880 08077885

08077890 08077905

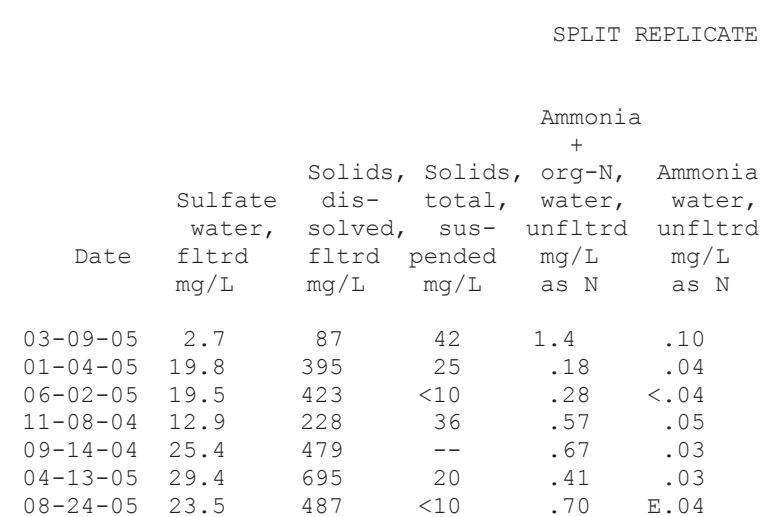

.17

.203

.034

160 


\section{Water-Quality, Sediment-Quality, Stream-Habitat, and Biological Data for Mustang Bayou, Texas, 2004-05}

Appendix 2. Quality-control ( $\mathrm{OC})$ data associated with periodically collected water-quality samples from Mustang Bayou near Houston, Texas, September 2004-August, 2005-Continued.

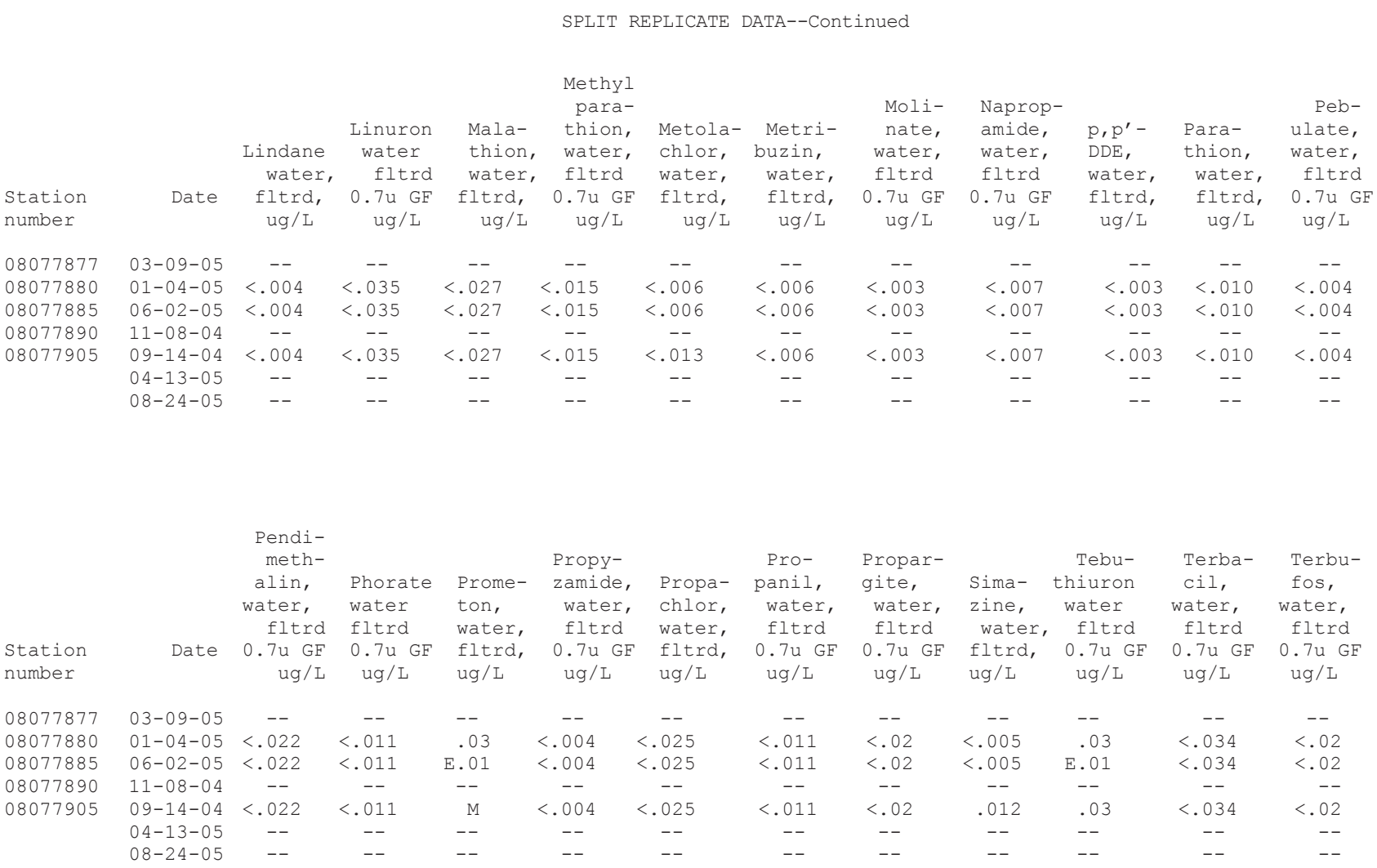

\begin{tabular}{|c|c|c|c|c|c|c|}
\hline & & $\begin{array}{c}\text { Thio- } \\
\text { bencarb } \\
\text { water } \\
\text { fltrd }\end{array}$ & $\begin{array}{l}\text { Tri- } \\
\text { allate, } \\
\text { water, } \\
\text { fltrd }\end{array}$ & $\begin{array}{l}\text { Tri- } \\
\text { flur- } \\
\text { alin, } \\
\text { water, } \\
\text { fltrd }\end{array}$ & $\begin{array}{l}\text { Sus- } \\
\text { pended } \\
\text { sedi- } \\
\text { ment } \\
\text { concen- }\end{array}$ & $\begin{array}{l}\text { Stream- } \\
\text { flow } \\
\text { sever- }\end{array}$ \\
\hline $\begin{array}{l}\text { Station } \\
\text { number }\end{array}$ & Date & $\begin{array}{c}0.7 \mathrm{u} \mathrm{GF} \\
\mathrm{ug} / \mathrm{L}\end{array}$ & $\begin{array}{c}0.7 u \text { GF } \\
u g / L\end{array}$ & $\begin{array}{c}0.7 u \text { GF } \\
u g / L\end{array}$ & $\begin{array}{c}\text { tration } \\
\mathrm{mg} / \mathrm{L}\end{array}$ & $\begin{array}{l}\text { ity, } \\
\text { code }\end{array}$ \\
\hline 08077877 & $\begin{array}{l}03-09-05 \\
07-13-05\end{array}$ & $\begin{array}{l}-- \\
--\end{array}$ & $\begin{array}{l}-- \\
--\end{array}$ & $\begin{array}{l}-- \\
--\end{array}$ & 26 & $\begin{array}{l}3 \\
--\end{array}$ \\
\hline 08077880 & $01-04-05$ & $<.010$ & $<.006$ & $<.009$ & 73 & 2 \\
\hline 08077885 & $06-02-05$ & $<.010$ & $<.006$ & $<.009$ & 13 & 3 \\
\hline 08077890 & $11-08-04$ & -- & -- & -- & 38 & 3 \\
\hline 08077905 & $\begin{array}{l}09-14-04 \\
04-13-05 \\
08-24-05 \\
08-24-05\end{array}$ & $\begin{array}{c}<.010 \\
-- \\
-- \\
.133\end{array}$ & $\begin{array}{c}<.002 \\
-- \\
-- \\
.125\end{array}$ & $\begin{array}{c}<.009 \\
-- \\
-- \\
.096\end{array}$ & $\begin{array}{c}-- \\
51 \\
4 \\
--\end{array}$ & $\begin{array}{l}3 \\
2 \\
3 \\
3\end{array}$ \\
\hline
\end{tabular}

E -- Estimated.

M -- Presence verified but not quantified. 


\section{Appendix 3-Water-Quality Properties and Sediment-Quality Constituents}


Blank Page 
Appendix 3. Water-quality properties and sediment-quality constituents at site M1 in Mustang Bayou near Houston, Texas, September 2005.

[mm, millimeters; Hg, mercury; mg/L, milligrams per liter; unfltrd, unfiltered; us/cm, microsiemens per centimeter; deg C, degrees Celsius; sedimnt (sed), sediment; ug/kg, micrograms per kilogram; ug/g, micrograms per gram]

08077905 Mustang Bayou at FM 2917 near Liverpool, TX

SEDIMENT-QUALITY DATA, SEPTEMBER 2005

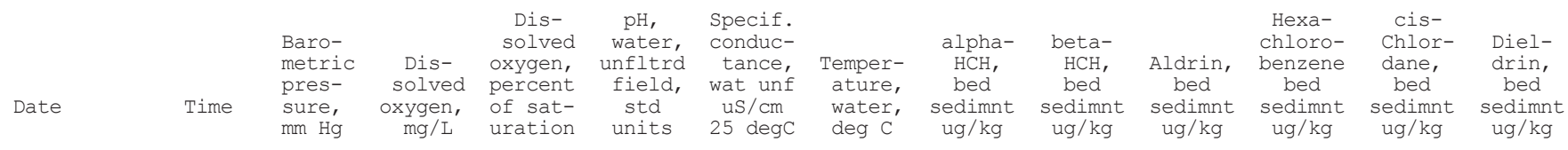

$$
\begin{aligned}
& \begin{array}{lllllllllll}
\operatorname{SEP} & \\
27 \ldots & 0845 & 762 & 1.3 & 16 & 7.3 & 674 & 28.8 & <1.5 & <.5 \quad<2.0 & <3.0 \quad<1.0
\end{array}
\end{aligned}
$$

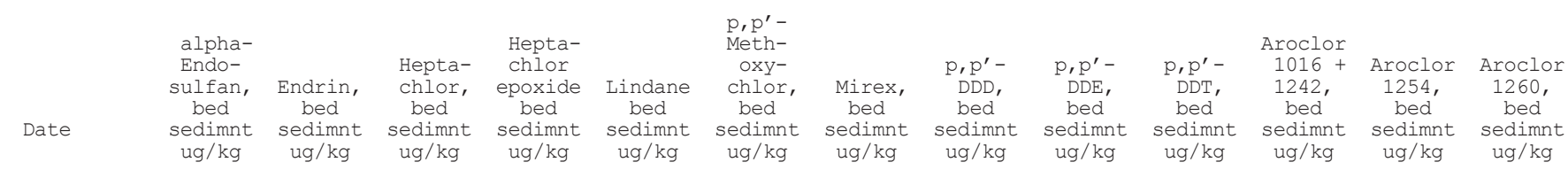

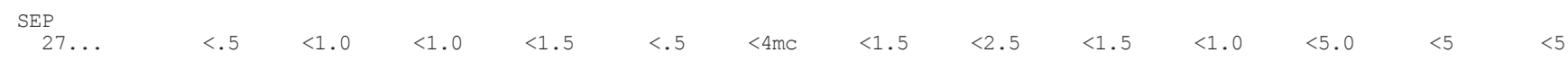

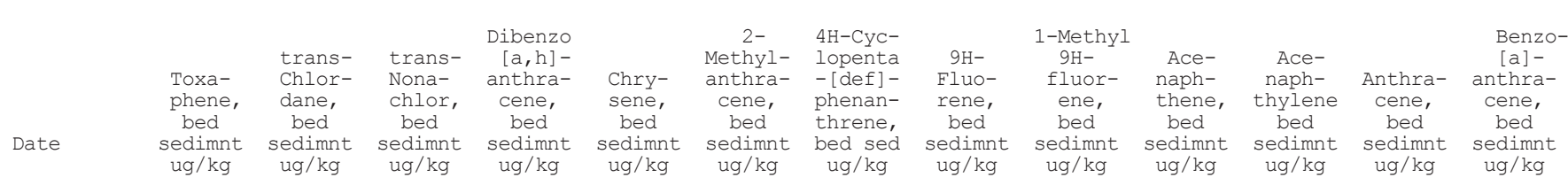

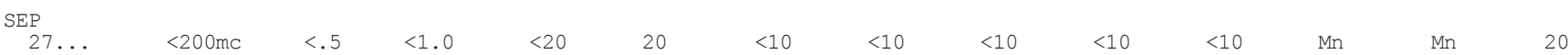

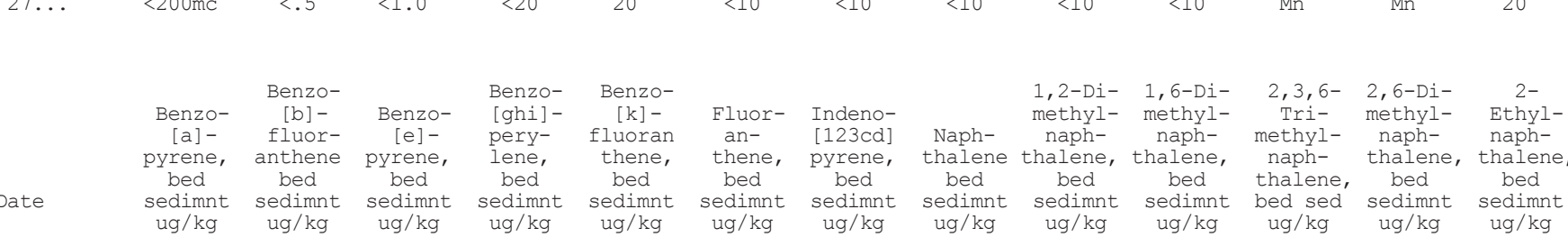

$$
\begin{aligned}
& \begin{array}{rllllllll}
\mathrm{SEP} \\
27 \ldots & 20 & 30 & 20 & <20 & 20 & 20 & 20 & <10 \quad<10 \quad<10
\end{array}
\end{aligned}
$$

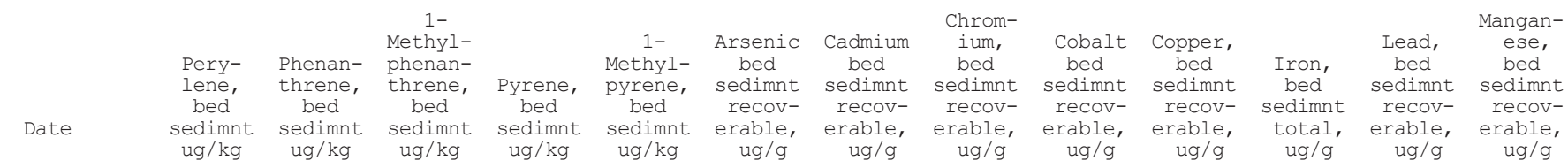

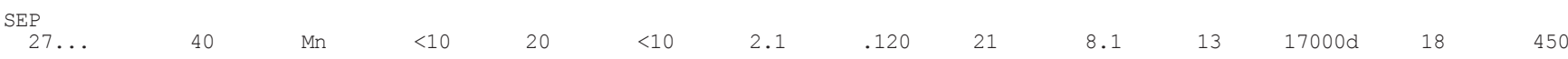

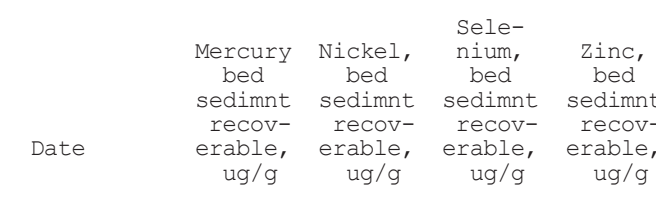

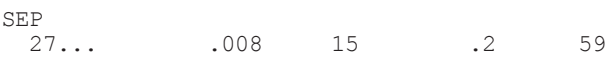

$$
\begin{aligned}
& \text { Remark codes used in this table: } \\
& <-- \text { Less than. } \\
& \text { M -- Presence verified but not quantified. } \\
& \text { Value qualifier codes used in this table: } \\
& \text { c -- See laboratory comment } \\
& \text { d -- Diluted sample: method hi range exceeded } \\
& \text { m -- Value is highly variable by this method } \\
& \mathrm{n} \text {-- Below the LRL and above the LT-MDL }
\end{aligned}
$$


Blank Page 
Appendix 4-Stream-Habitat Data and Computed Metrics 
Blank Page 
Appendix 4. Stream-habitat data and computed metrics for representative reach at each of six sites in Mustang Bayou near Houston, Texas, September 2004-August 2005.

$\left[\mathrm{km}^{2}\right.$, square kilometers; m, meters; $\mathrm{km}$, kilometers; $\mathrm{ft}^{3} / \mathrm{s}$, cubic feet per second; --, no value; $\mathrm{ft} / \mathrm{s}$, feet per second; <, less than; >, greater than]

\begin{tabular}{|c|c|c|c|c|c|c|c|c|c|}
\hline \multirow{3}{*}{ Metric } & \multicolumn{9}{|c|}{ Site and survey } \\
\hline & \multicolumn{3}{|c|}{ M1 } & \multicolumn{3}{|c|}{$\mathrm{M} 2$} & \multicolumn{3}{|c|}{ M3 } \\
\hline & SEP 2004 & APR 2005 & AUG 2005 & SEP 2004 & APR 2005 & AUG 2005 & SEP 2004 & APR 2005 & AUG 2005 \\
\hline \multicolumn{10}{|l|}{ Site characteristics } \\
\hline Drainage area above location $\left(\mathrm{km}^{2}\right)$ & 122 & 122 & 122 & 86.5 & 86.5 & 86.5 & 72.3 & 72.3 & 72.3 \\
\hline Altitude of land surface at reach (m) & 4.3 & 4.3 & 4.3 & 6.1 & 6.1 & 6.1 & 11.6 & 11.6 & 11.6 \\
\hline Number of permitted dischargers above reach & 10 & 10 & 10 & 10 & 10 & 10 & 8 & 8 & 8 \\
\hline Dominant land use at reach & agriculture & agriculture & agriculture & agriculture & agriculture & agriculture & urban & urban & urban \\
\hline Land development impact & low & low & low & moderate & moderate & moderate & high & high & high \\
\hline Aesthetics & common & common & common & natural & natural & natural & common & common & common \\
\hline Reach length (km) & .183 & .183 & .183 & .152 & .152 & .152 & .155 & .155 & .155 \\
\hline Stream slope at reach $(\mathrm{m} / \mathrm{m})$ & .00022 & .00022 & .00022 & .00045 & .00045 & .00045 & .00048 & .00048 & .00048 \\
\hline \multicolumn{10}{|l|}{ Stream-channel attributes } \\
\hline Average width (m) & 12.2 & 10.0 & 10.8 & 4.4 & 3.8 & 4.0 & 6.2 & 6.9 & 7.7 \\
\hline Average depth (m) & 1.04 & .36 & .57 & .33 & .39 & .38 & .33 & .39 & .38 \\
\hline Streamflow, instantaneous $\left(\mathrm{ft}^{3} / \mathrm{s}\right)$ & -- & 1.08 & 4.56 & 9.44 & 14.7 & 11.3 & 6.97 & 15.1 & 9.55 \\
\hline Average velocity (ft/s) & -- & .04 & .07 & .82 & 1.05 & .74 & .45 & .76 & .36 \\
\hline Number of pools & 0 & 0 & 0 & 0 & 0 & 0 & 0 & 0 & 1 \\
\hline Total number of stream bends & 0 & 0 & 0 & 3 & 3 & 3 & 1 & 1 & 1 \\
\hline Number of well-defined bends & 0 & 0 & 0 & 0 & 0 & 0 & 0 & 0 & 0 \\
\hline Number of moderately-defined bends & 0 & 0 & 0 & 1 & 1 & 1 & 0 & 0 & 0 \\
\hline Number of poorly-defined bends & 0 & 0 & 0 & 2 & 2 & 2 & 1 & 1 & 1 \\
\hline Number of riffles & 0 & 0 & 0 & 1 & 1 & 1 & 0 & 0 & 1 \\
\hline Dominant substrate type & silt & silt & silt & silt & silt & clay & sand & silt & sand \\
\hline Average percentage of gravel & 0 & 0 & 0 & 6.0 & 4.2 & $<5.0$ & $<2.0$ & 0 & $<1.0$ \\
\hline Number of instream cover types & 2 & 2 & 3 & 2 & 2 & 3 & 1 & 1 & 2 \\
\hline Average percentage instream cover & 10.0 & 5.6 & 54.0 & 17.6 & 11.4 & 7.6 & 19.0 & 19.0 & 52.0 \\
\hline \multicolumn{10}{|l|}{ Riparian attributes } \\
\hline Average bank slope (degrees) & 39.5 & 50.7 & 30.2 & 39.5 & 48.2 & 49.2 & 35.5 & 31.3 & 24.6 \\
\hline Average bank erosion potential percentage & $<5$ & 22.0 & 21.0 & 4.0 & 4.0 & 6.0 & 25.5 & 33.0 & 54.0 \\
\hline Mean width of natural buffer vegetation (m) & $>30.5$ & $>30.5$ & $>30.5$ & $>30.5$ & $>30.5$ & $>30.5$ & $<2.6$ & 7.3 & 6.7 \\
\hline Riparian vegetation: percentage trees & 2.5 & 2.0 & 0 & 10.3 & 9.8 & 9.0 & 0 & 0 & 0 \\
\hline Riparian vegetation: percentage shrubs & 19.0 & 15.0 & 15.0 & 48.7 & 52.5 & 44.0 & 3.0 & 3.5 & 1.5 \\
\hline Riparian vegetation: percentage grasses & 69.5 & 78.0 & 84.0 & 41.0 & 37.7 & 47.0 & 85.5 & 83.5 & 49.5 \\
\hline Riparian vegetation: percentage cultivated fields & 0 & 0 & 0 & 0 & 0 & 0 & 0 & 0 & 0 \\
\hline Riparian vegetation: percentage other & 9.0 & 5.0 & 1.0 & 0 & 0 & 0 & 11.5 & 13.0 & 49.0 \\
\hline Average percentage tree canopy & 0 & 0 & 0 & 0 & 0 & 0 & 0 & 0 & 0 \\
\hline
\end{tabular}




\section{Water-Quality, Sediment-Quality, Stream-Habitat, and Biological Data for Mustang Bayou, Texas, 2004-05}

Appendix 4. Stream-habitat data and computed metrics for representative reach at each of six sites in Mustang Bayou near Houston, Texas, September 2004-August 2005-Continued.

\begin{tabular}{|c|c|c|c|c|c|c|c|c|c|}
\hline \multirow{3}{*}{ Metric } & \multicolumn{9}{|c|}{ Site and survey } \\
\hline & \multicolumn{3}{|c|}{ M4 } & \multicolumn{3}{|c|}{ M5 } & \multicolumn{3}{|c|}{ M6 } \\
\hline & SEP 2004 & APR 2005 & AUG 2005 & SEP 2004 & APR 2005 & AUG 2005 & SEP 2004 & APR 2005 & AUG 2005 \\
\hline \multicolumn{10}{|l|}{ Site characteristics } \\
\hline Drainage area above location $\left(\mathrm{km}^{2}\right)$ & 52.3 & 52.3 & 52.3 & 23.6 & 23.6 & 23.6 & 14.6 & 14.6 & 14.6 \\
\hline Altitude of land surface at reach (m) & 13.7 & 13.7 & 13.7 & 18.3 & 18.3 & 18.3 & 19.8 & 19.8 & 19.8 \\
\hline Number of permitted dischargers above reach & 8 & 8 & 8 & 4 & 4 & 4 & 1 & 1 & 1 \\
\hline Dominant land use at reach & grassland & grassland & grassland & quarry & quarry & quarry & pasture & pasture & pasture \\
\hline Land development impact & moderate & moderate & moderate & moderate & high & high & low & low & low \\
\hline Aesthetics & common & common & offensive & common & offensive & offensive & common & common & common \\
\hline Reach length (km) & .305 & .305 & .305 & .244 & .244 & .244 & .219 & .219 & .219 \\
\hline Stream slope within reach $(\mathrm{m} / \mathrm{m})$ & .00018 & .00018 & .00018 & .00025 & .00025 & .00025 & .00043 & .00043 & .00043 \\
\hline \multicolumn{10}{|l|}{ Stream-channel attributes } \\
\hline Average width (m) & 8.47 & 7.32 & 9.08 & 5.42 & 5.91 & 14.57 & 6.04 & 3.96 & 6.46 \\
\hline Average depth (m) & .43 & .36 & .46 & .29 & .30 & .44 & .19 & .17 & .25 \\
\hline Streamflow, instantaneous $\left(\mathrm{ft}^{3} / \mathrm{s}\right)$ & 5.78 & 7.65 & 5.08 & 3.98 & 3.39 & 3.80 & .103 & .223 & .00 \\
\hline Average velocity (ft/s) & .21 & .28 & .16 & .31 & .20 & .07 & .10 & .02 & .00 \\
\hline Number of pools & 0 & 0 & 0 & 0 & 0 & 0 & 0 & 0 & 0 \\
\hline Total number of stream bends & 2 & 2 & 2 & 8 & 1 & 1 & 0 & 0 & 0 \\
\hline Number of well-defined bends & 0 & 0 & 0 & 0 & 0 & 0 & 0 & 0 & 0 \\
\hline Number of moderately-defined bends & 0 & 0 & 0 & 4 & 1 & 1 & 0 & 0 & 0 \\
\hline Number of poorly-defined bends & 2 & 2 & 2 & 4 & 0 & 0 & 0 & 0 & 0 \\
\hline Number of riffles & 0 & 0 & 0 & 0 & 0 & 0 & 0 & 0 & 0 \\
\hline Dominant substrate type & silt & silt & silt & silt & silt & silt & silt & silt & silt \\
\hline Average percentage of gravel & 0 & 2.0 & 8.0 & 0 & 0 & 0 & 0 & 0 & 0 \\
\hline Number of instream cover types & 3 & 1 & 2 & 1 & 1 & 1 & 1 & 1 & 1 \\
\hline Average percentage instream cover & 46.0 & 4.4 & 22.0 & 49.0 & 35.0 & 84.0 & 9.0 & 4.8 & 14.0 \\
\hline \multicolumn{10}{|l|}{ Riparian attributes } \\
\hline Average bank slope (degrees) & 36.3 & 28.4 & 30.5 & 16.5 & 10.2 & 20.1 & 11.5 & 18.0 & 8.0 \\
\hline Average bank erosion potential percentage & 10.5 & 4.0 & 6.5 & $<5$ & 21.5 & 6.0 & 7.5 & 13.0 & 19.8 \\
\hline Mean width of natural buffer vegetation (m) & 14.6 & 4.6 & 5.7 & 19.5 & 4.4 & 6.1 & 0 & 0 & 0 \\
\hline Riparian vegetation: percentage trees & 6.0 & .1 & 5.5 & 27.0 & 0 & 9.8 & 1.2 & 0 & 0 \\
\hline Riparian vegetation: percentage shrubs & 14.5 & 9.0 & 5.0 & 14.5 & 0 & 46.2 & 0 & 0 & 0 \\
\hline Riparian vegetation: percentage grasses & 79.5 & 85.0 & 89.5 & 58.5 & 64.0 & 40.0 & 98.8 & 100.0 & 100.0 \\
\hline Riparian vegetation: percentage cultivated fields & 0 & 0 & 0 & 0 & 0 & 0 & 0 & 0 & 0 \\
\hline Riparian vegetation: percentage other & 0 & 5.9 & 0 & 0 & 36.0 & 4.0 & 0 & 0 & 0 \\
\hline Average percentage tree canopy & 0 & 0 & 0 & 21.0 & 0 & 0 & 0 & 0 & 0 \\
\hline
\end{tabular}




\section{Appendix 5-Benthic Macroinvertebrate Taxa and Counts of Individual Taxa}


Blank Page 


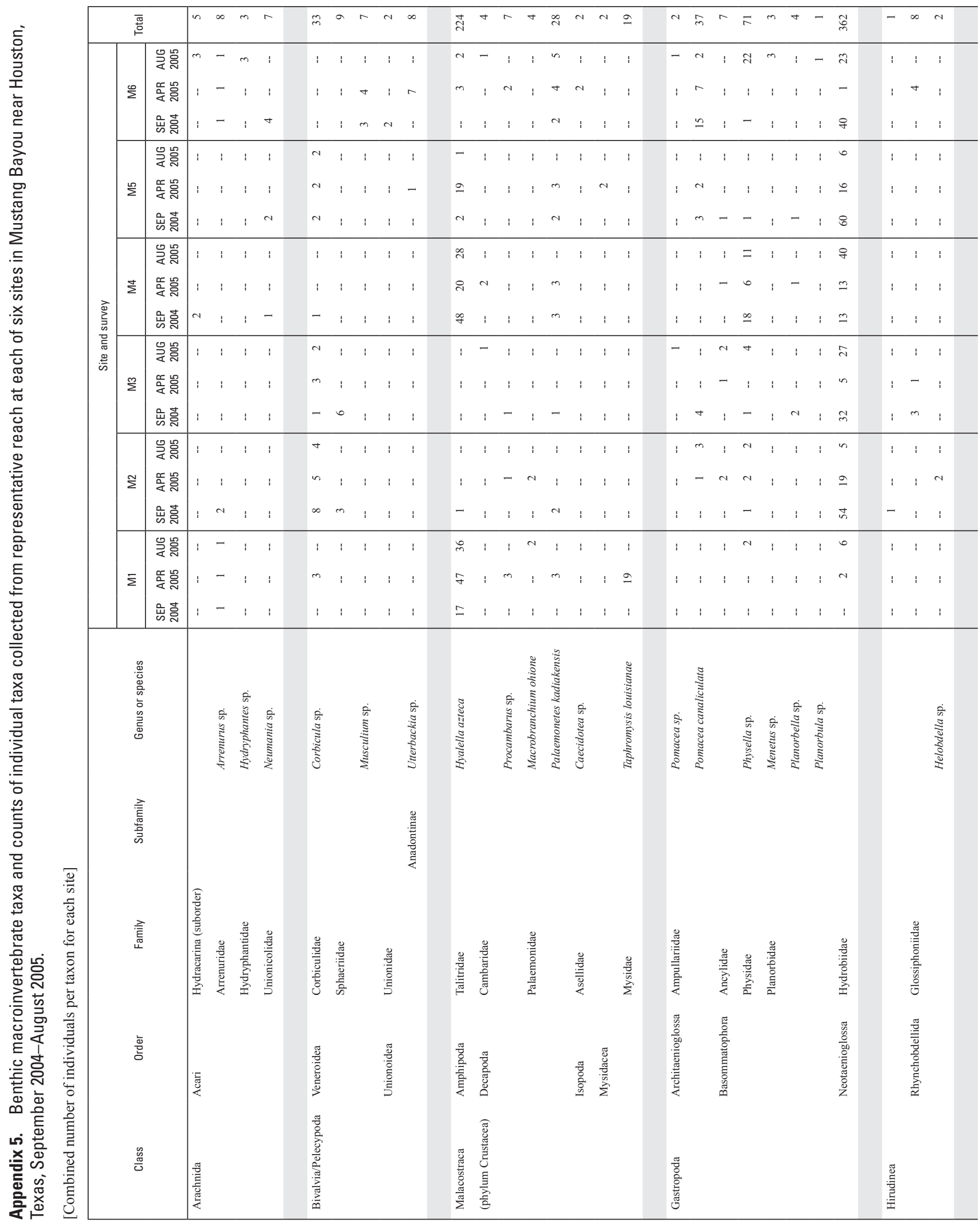




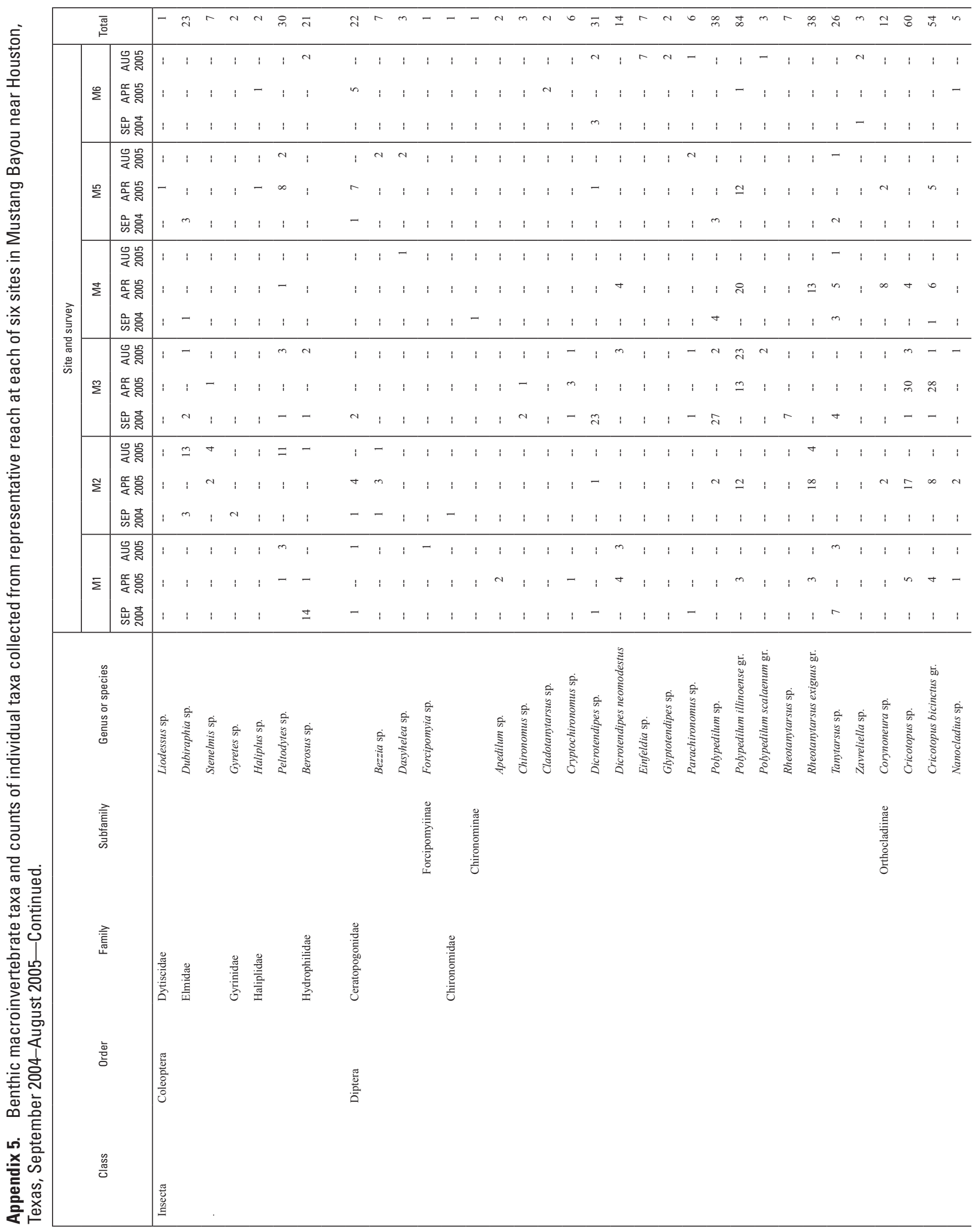




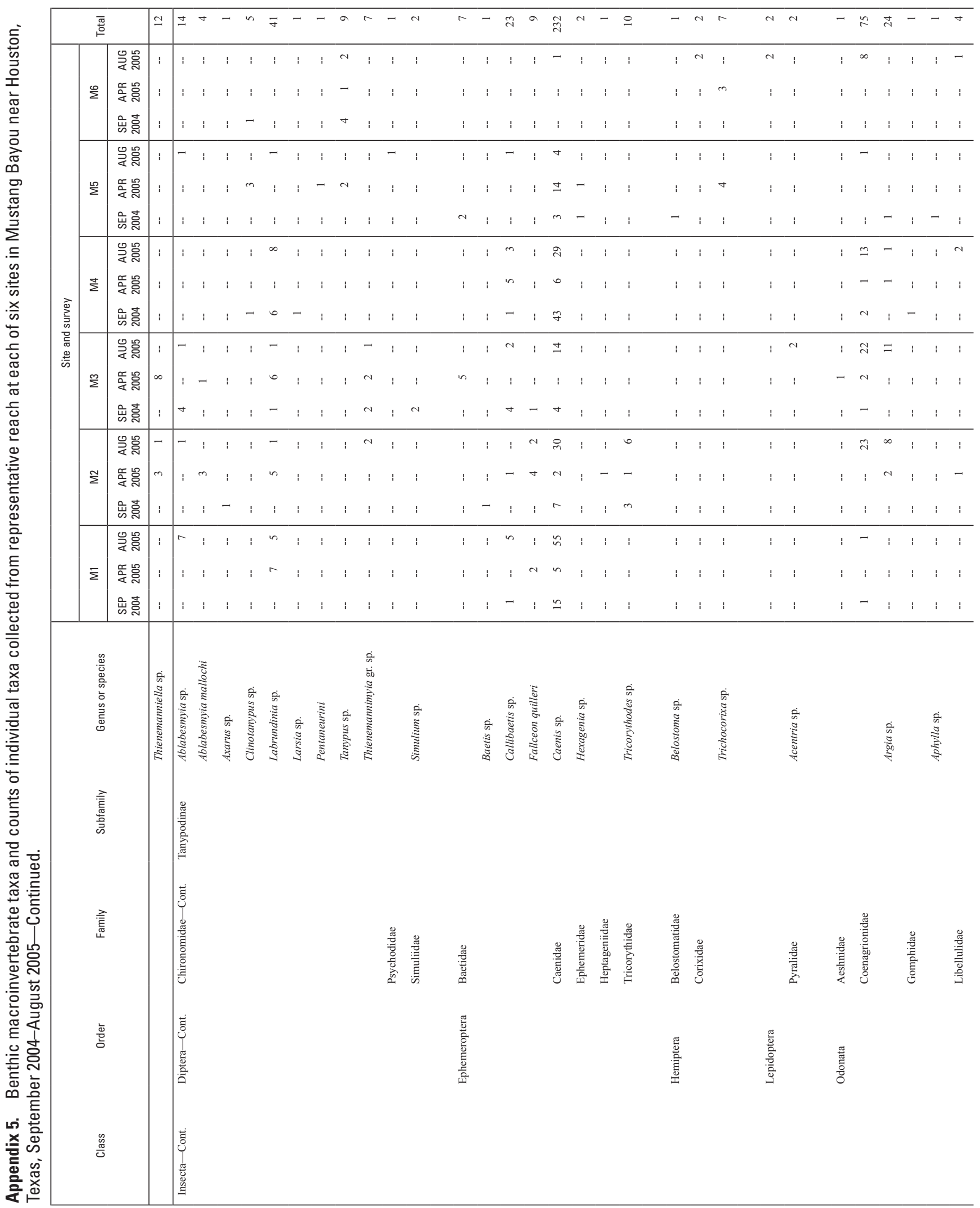




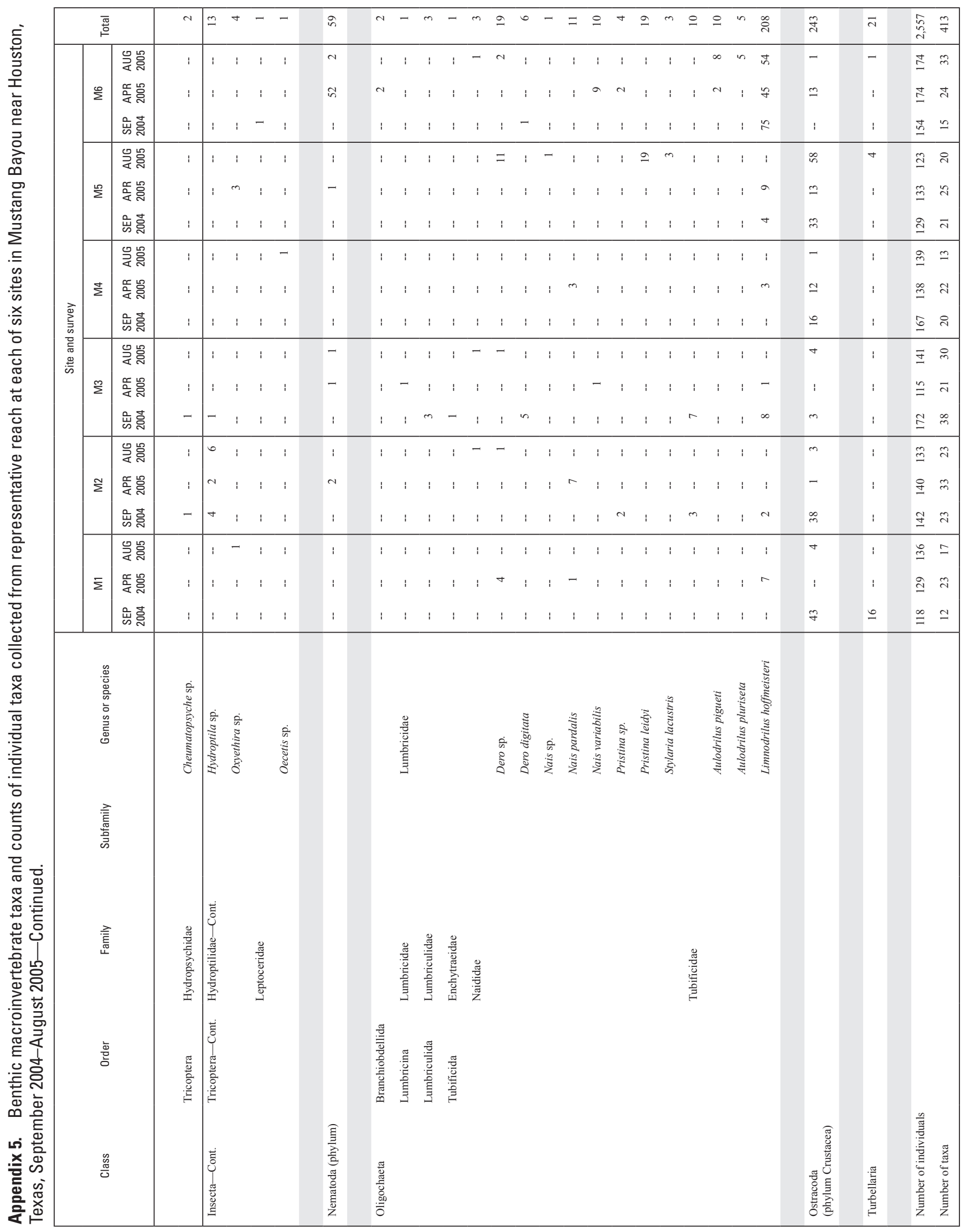




\section{Appendix 6-Benthic Macroinvertebrate Data and Computed Metrics}


Blank Page 
Appendix 6. Benthic macroinvertebrate data and computed metrics for representative reach at each of six sites in Mustang Bayou near Houston, Texas, September 2004-August 2005.

[EPT, Ephemeroptera, Plecoptera, Trichoptera]

\begin{tabular}{|c|c|c|c|c|c|c|c|c|c|}
\hline \multirow{3}{*}{ Metric } & \multicolumn{9}{|c|}{ Site and survey } \\
\hline & \multicolumn{3}{|c|}{ M1 } & \multicolumn{3}{|c|}{ M2 } & \multicolumn{3}{|c|}{ M3 } \\
\hline & SEP 2004 & APR 2005 & AUG 2005 & SEP 2004 & APR 2005 & AUG 2005 & SEP 2004 & APR 2005 & AUG 2005 \\
\hline \multicolumn{10}{|l|}{ Richness measures } \\
\hline Number of taxa ${ }^{1}$ & 10 & 13 & 14 & 20 & 23 & 18 & 23 & 11 & 18 \\
\hline Total number of individuals & 118 & 129 & 136 & 142 & 140 & 133 & 172 & 115 & 141 \\
\hline Number of EPT taxa ${ }^{1}$ (richness) & 2 & 2 & 3 & 5 & 6 & 4 & 5 & 1 & 2 \\
\hline Number of Ephemeroptera taxa ${ }^{1}$ & 2 & 2 & 2 & 3 & 5 & 3 & 3 & 1 & 2 \\
\hline Number of Plecoptera taxa ${ }^{1}$ & 0 & 0 & 0 & 0 & 0 & 0 & 0 & 0 & 0 \\
\hline Number of Trichoptera taxa ${ }^{1}$ & 0 & 0 & 1 & 2 & 1 & 1 & 2 & 0 & 0 \\
\hline \multicolumn{10}{|l|}{ Composition measures } \\
\hline Percentage $^{2}$ Ephemeroptera & 13.56 & 5.43 & 44.12 & 7.75 & 6.43 & 28.57 & 5.23 & 4.35 & 11.35 \\
\hline Percentage $^{2}$ Baetidae & 0.85 & 1.55 & 3.68 & 0.70 & 3.57 & 1.50 & 2.91 & 4.35 & 1.42 \\
\hline Percentage $^{2}$ Plecoptera & 0 & 0 & 0 & 0 & 0 & 0 & 0 & 0 & 0 \\
\hline Percentage $^{2}$ Tricoptera & 0 & 0 & 0.74 & 3.52 & 1.43 & 4.51 & 1.16 & 0 & 0 \\
\hline Percentage $^{2}$ Coleoptera & 11.86 & 1.55 & 2.20 & 3.52 & 1.43 & 21.80 & 2.32 & 0.87 & 4.26 \\
\hline Percentage $^{2}$ Elmidae & 0 & 0 & 0 & 2.11 & 1.43 & 12.78 & 1.16 & 0.87 & 0.71 \\
\hline Percentage $^{2}$ Diptera & 8.47 & 23.26 & 14.70 & 2.82 & 57.14 & 7.52 & 45.35 & 80.00 & 28.37 \\
\hline Percentage $^{2}$ Chironomidae & 7.63 & 23.26 & 13.23 & 1.41 & 52.14 & 6.77 & 43.02 & 80.00 & 28.37 \\
\hline Percentage $^{2}$ Odonata & 0.85 & 0 & 0.74 & 0 & 2.14 & 23.31 & 0.58 & 2.61 & 23.40 \\
\hline Percentage $^{2}$ Oligochaeta & 0 & 9.30 & 0 & 4.93 & 5.00 & 1.50 & 13.95 & 2.61 & 1.42 \\
\hline Number of non-insect taxa ${ }^{1}$ & 4 & 8 & 6 & 10 & 11 & 6 & 11 & 6 & 9 \\
\hline $\begin{array}{l}\text { Percentage non-insect } \\
\quad \text { individuals }{ }^{1}\end{array}$ & 65.25 & 69.77 & 37.50 & 82.39 & 31.43 & 14.28 & 45.35 & 12.17 & 31.20 \\
\hline First dominant taxon & Ostracoda & $\begin{array}{l}\text { Hyalella } \\
\text { azteca }\end{array}$ & Caenis sp. & Hydrobiidae & Hydrobiidae & Caenis sp. & Hydrobiidae & Cricotopus sp. & Hydrobiidae \\
\hline Second dominant taxon & $\begin{array}{l}\text { Hyalella } \\
\text { azteca }\end{array}$ & $\begin{array}{l}\text { Taphromysis } \\
\text { louisianae }\end{array}$ & Hyalella azteca & Ostracoda & $\begin{array}{l}\text { Rheotanytarsus } \\
\text { exiguus gr. }\end{array}$ & Coenagrionidae & Polypedilum sp. & $\begin{array}{l}\text { Cricotopus } \\
\text { bicinctus gr. }\end{array}$ & $\begin{array}{l}\text { Polypedilum } \\
\text { illinoense gr. }\end{array}$ \\
\hline Third dominant taxon & Turbellaria & $\begin{array}{l}\text { Limnodrilus } \\
\text { hoffmeisteri }\end{array}$ & Ablabesmyia sp. & Corbicula sp. & Cricotopus sp. & Dubiraphia sp. & Dicrotendipes sp. & $\begin{array}{l}\text { Polypedilum } \\
\text { illinoense gr. }\end{array}$ & Coenagrionidae \\
\hline Percentage $^{2}$ first dominant taxon & 36.44 & 36.43 & 40.44 & 38.03 & 13.57 & 22.56 & 18.60 & 26.09 & 19.15 \\
\hline Percentage $^{2}$ two dominant taxa & 50.85 & 51.16 & 66.91 & 64.79 & 26.43 & 39.85 & 34.30 & 50.43 & 35.46 \\
\hline Percentage $^{2}$ three dominant taxa & 64.41 & 56.59 & 72.06 & 70.42 & 38.57 & 49.62 & 47.67 & 61.74 & 51.06 \\
\hline \multicolumn{10}{|l|}{ Tolerance measures } \\
\hline Number of intolerant taxa ${ }^{3}$ & 3 & 3 & 5 & 7 & 9 & 7 & 8 & 3 & 5 \\
\hline Number of tolerant tax $a^{3}$ & 6 & 8 & 7 & 12 & 12 & 9 & 14 & 7 & 10 \\
\hline Percentage $^{2}$ tolerant individuals & 84.62 & 93.46 & 88.80 & 51.43 & 73.13 & 67.19 & 73.21 & 90.26 & 76.47 \\
\hline Hilsenhoff biotic index (HBI) & 7.37 & 7.55 & 6.93 & 6.26 & 6.12 & 6.60 & 6.89 & 6.75 & 6.96 \\
\hline \multicolumn{10}{|l|}{ Trophic/habitat measures } \\
\hline $\begin{array}{l}\text { Percentage }{ }^{2} \text { dominant functional } \\
\text { feeding group }\end{array}$ & 66.10 & 55.83 & 74.63 & 43.57 & 28.68 & 44.44 & 36.90 & 61.74 & 27.54 \\
\hline Percentage $^{2}$ filterers $^{3}$ & 5.93 & 2.50 & 2.24 & 8.57 & 13.97 & 3.17 & 12.50 & 0 & 0 \\
\hline Percentage $^{2}$ gatherers $^{3}$ & 66.10 & 55.83 & 74.63 & 43.57 & 17.65 & 44.44 & 36.90 & 14.78 & 17.39 \\
\hline Percentage $^{2}$ predators $^{3}$ & 16.11 & 7.50 & 11.93 & 3.57 & 14.71 & 28.57 & 8.33 & 14.78 & 27.54 \\
\hline Percentage $^{2}$ scrapers-grazers ${ }^{3}$ & 0 & 1.67 & 5.97 & 39.29 & 19.11 & 8.73 & 19.64 & 6.09 & 25.36 \\
\hline Percentage $^{2}$ shredders $^{3}$ & 11.86 & 11.67 & 2.24 & 0 & 28.68 & 9.52 & 18.45 & 61.74 & 26.09 \\
\hline Percentage $^{2}$ piercer-herbivores ${ }^{3}$ & 0 & 0 & 0.75 & 2.86 & 1.47 & 4.76 & 0.60 & 0 & 0 \\
\hline Percentage $^{2}$ unclassified & 0 & 20.83 & 2.24 & 2.14 & 4.41 & 0.81 & 3.58 & 2.61 & 3.62 \\
\hline
\end{tabular}


74 Water-Quality, Sediment-Quality, Stream-Habitat, and Biological Data for Mustang Bayou, Texas, 2004-05

Appendix 6. Benthic macroinvertebrate data and computed metrics for representative reach at each of six sites in Mustang Bayou near Houston, Texas, September 2004-August 2005-Continued.

\begin{tabular}{|c|c|c|c|c|c|c|c|c|c|}
\hline \multirow{3}{*}{ Metric } & \multicolumn{9}{|c|}{ Site and survey } \\
\hline & \multicolumn{3}{|c|}{ M4 } & \multicolumn{3}{|c|}{ M5 } & \multicolumn{3}{|c|}{ M6 } \\
\hline & SEP 2004 & APR 2005 & AUG 2005 & SEP 2004 & APR 2005 & AUG 2005 & SEP 2004 & APR 2005 & AUG 2005 \\
\hline \multicolumn{10}{|l|}{ Richness measures } \\
\hline Number of taxa ${ }^{1}$ & 13 & 15 & 12 & 20 & 19 & 14 & 10 & 17 & 20 \\
\hline Total number of individuals & 167 & 138 & 139 & 129 & 133 & 123 & 154 & 174 & 174 \\
\hline Number of EPT taxa ${ }^{1}$ (richness) & 2 & 2 & 3 & 3 & 3 & 2 & 1 & 0 & 1 \\
\hline Number of Ephemeroptera taxa ${ }^{1}$ & 2 & 2 & 2 & 3 & 2 & 2 & 0 & 0 & 1 \\
\hline Number of Plecoptera taxa ${ }^{1}$ & 0 & 0 & 0 & 0 & 0 & 0 & 0 & 0 & 0 \\
\hline Number of Trichoptera taxa ${ }^{1}$ & 0 & 0 & 1 & 0 & 1 & 0 & 1 & 0 & 0 \\
\hline \multicolumn{10}{|l|}{ Composition measures } \\
\hline Percentage $^{2}$ EPT taxa & 26.35 & 7.97 & 23.74 & 4.65 & 13.54 & 4.06 & 0.65 & 0 & 0.57 \\
\hline Percentage $^{2}$ Ephemeroptera & 26.35 & 7.97 & 23.02 & 4.65 & 11.28 & 4.06 & 0 & 0 & 0.57 \\
\hline Percentage $^{2}$ Baetidae & 0.60 & 3.62 & 2.16 & 1.55 & 0 & 0.81 & 0 & 0 & 0 \\
\hline Percentage $^{2}$ Plecoptera & 0 & 0 & 0 & 0 & 0 & 0 & 0 & 0 & 0 \\
\hline Percentage $^{2}$ Tricoptera & 0 & 0 & 0.72 & 0 & 2.26 & 0 & 0.65 & 0 & 0 \\
\hline Percentage $^{2}$ Coleoptera & 0.60 & 0.72 & 0 & 2.32 & 7.52 & 1.63 & 0 & 0.57 & 1.15 \\
\hline Percentage $^{2}$ Elmidae & 0.60 & 0 & 0 & 2.32 & 0 & 0 & 0 & 0 & 0 \\
\hline Percentage $^{2}$ Diptera & 10.18 & 43.48 & 7.19 & 4.65 & 24.81 & 8.13 & 5.84 & 5.75 & 9.77 \\
\hline Percentage $^{2}$ Chironomidae & 10.18 & 43.48 & 6.47 & 3.88 & 19.55 & 4.06 & 5.84 & 2.87 & 9.77 \\
\hline Percentage $^{2}$ Odonata & 1.80 & 1.45 & 11.51 & 1.55 & 0 & 0.81 & 0 & 0 & 5.17 \\
\hline Percentage $^{2}$ Oligochaeta & 0 & 4.35 & 0 & 3.10 & 6.77 & 27.64 & 49.35 & 33.33 & 40.23 \\
\hline Number of non-insect taxa ${ }^{1}$ & 7 & 9 & 4 & 11 & 10 & 6 & 8 & 13 & 13 \\
\hline $\begin{array}{l}\text { Percentage non-insect } \\
\quad \text { individuals }{ }^{1}\end{array}$ & 61.08 & 46.38 & 57.55 & 86.05 & 51.13 & 85.36 & 93.51 & 91.95 & 81.03 \\
\hline \multicolumn{10}{|l|}{ Dominance measures } \\
\hline First dominant taxon & $\begin{array}{l}\text { Hyalella } \\
\text { azteca }\end{array}$ & $\begin{array}{l}\text { Hyalella } \\
\text { azteca }\end{array}$ & Hydrobiidae & Hydrobiidae & $\begin{array}{l}\text { Hyalella } \\
\text { azteca }\end{array}$ & Ostracoda & $\begin{array}{l}\text { Limnodrilus } \\
\text { hoffmeisteri }\end{array}$ & Nematoda & $\begin{array}{l}\text { Limnodrilus } \\
\text { hoffmeisteri }\end{array}$ \\
\hline Second dominant taxon & Caenis sp. & $\begin{array}{l}\text { Polypedilum } \\
\text { illinoense gr. }\end{array}$ & Caenis sp. & Ostracoda & Hydrobiidae & $\begin{array}{l}\text { Pristina } \\
\text { leidyi }\end{array}$ & Hydrobiidae & $\begin{array}{l}\text { Limnodrilus } \\
\text { hoffmeisteri }\end{array}$ & Hydrobiidae \\
\hline Third dominant taxon & Physella sp. & Hydrobiidae & $\begin{array}{l}\text { Hyalella } \\
\text { azteca }\end{array}$ & $\begin{array}{l}\text { Limnodrilus } \\
\text { hoffmeisteri }\end{array}$ & Caenis sp. & Dero sp. & $\begin{array}{l}\text { Pomacea } \\
\text { canaliculata }\end{array}$ & Ostracoda & Physella sp. \\
\hline Percentage $^{2}$ first dominant taxon & 28.74 & 14.49 & 28.78 & 46.51 & 14.28 & 47.15 & 48.70 & 29.88 & 31.03 \\
\hline Percentage $^{2}$ two dominant taxa & 54.49 & 28.98 & 49.64 & 72.09 & 26.32 & 62.60 & 74.68 & 55.75 & 44.25 \\
\hline Percentage $^{2}$ three dominant taxa & 65.27 & 38.40 & 69.78 & 75.19 & 36.84 & 71.54 & 84.42 & 63.22 & 56.90 \\
\hline \multicolumn{10}{|l|}{ Tolerance measures } \\
\hline Number of intolerant taxa ${ }^{3}$ & 4 & 4 & 5 & 5 & 5 & 4 & 4 & 5 & 5 \\
\hline Number of tolerant taxa ${ }^{3}$ & 8 & 11 & 6 & 12 & 8 & 10 & 5 & 7 & 11 \\
\hline Percentage $^{2}$ tolerant individuals & 89.16 & 83.33 & 60.58 & 44.72 & 75.41 & 88.07 & 65.92 & 56.29 & 78.67 \\
\hline Hilsenhoff biotic index (HBI) & 7.29 & 7.03 & 6.78 & 6.22 & 7.06 & 7.95 & 8.51 & 7.41 & 7.72 \\
\hline \multicolumn{10}{|l|}{ Trophic/habitat measures } \\
\hline $\begin{array}{l}\text { Percentage }{ }^{2} \text { dominant functional } \\
\text { feeding group }\end{array}$ & 65.87 & 41.91 & 44.29 & 51.24 & 47.58 & 85.12 & 52.63 & 54.67 & 50.00 \\
\hline Percentage $^{2}$ filterers ${ }^{3}$ & 2.40 & 13.24 & 0.71 & 1.65 & 0 & 0.83 & 3.29 & 0 & 0 \\
\hline Percentage $^{2}$ gatherers $^{3}$ & 65.87 & 41.91 & 44.29 & 38.84 & 47.58 & 85.12 & 52.63 & 54.67 & 50.00 \\
\hline Percentage $^{2}$ predators $^{3}$ & 8.38 & 1.47 & 18.57 & 3.31 & 15.32 & 7.44 & 6.58 & 43.99 & 11.76 \\
\hline Percentage $^{2}$ scrapers-grazers $^{3}$ & 18.56 & 14.71 & 36.43 & 51.24 & 12.90 & 4.96 & 26.97 & 0.67 & 28.24 \\
\hline Percentage $^{2}$ shredders $^{3}$ & 2.99 & 22.79 & 0 & 2.48 & 20.16 & 1.65 & 0 & 0.67 & 2.94 \\
\hline Percentage $^{2}$ piercer-herbivores ${ }^{3}$ & 0 & 0 & 0 & 0 & 2.42 & 0 & 0 & 0 & 1.18 \\
\hline Percentage $^{2}$ unclassified & 1.80 & 5.88 & 0 & 2.48 & 1.62 & 0 & 10.53 & 0 & 5.88 \\
\hline
\end{tabular}

${ }^{1}$ Taxa designation determined from guidance for identification of specimens collected in Rapid Bioassessment Protocol kicknet and snag samples (Texas Natural Resource Conservation Commission, 1999b).

${ }^{2}$ Percentage computed as ratio of number of individuals in a category to total number of benthic macroinvertebrates collected at site.

${ }^{3}$ Categorization of taxa determined from Texas Natural Resource Conservation Commission (1999b, table B-11). 


\section{Appendix 7-Fish Taxa and Counts of Individual Taxa}


Blank Page 


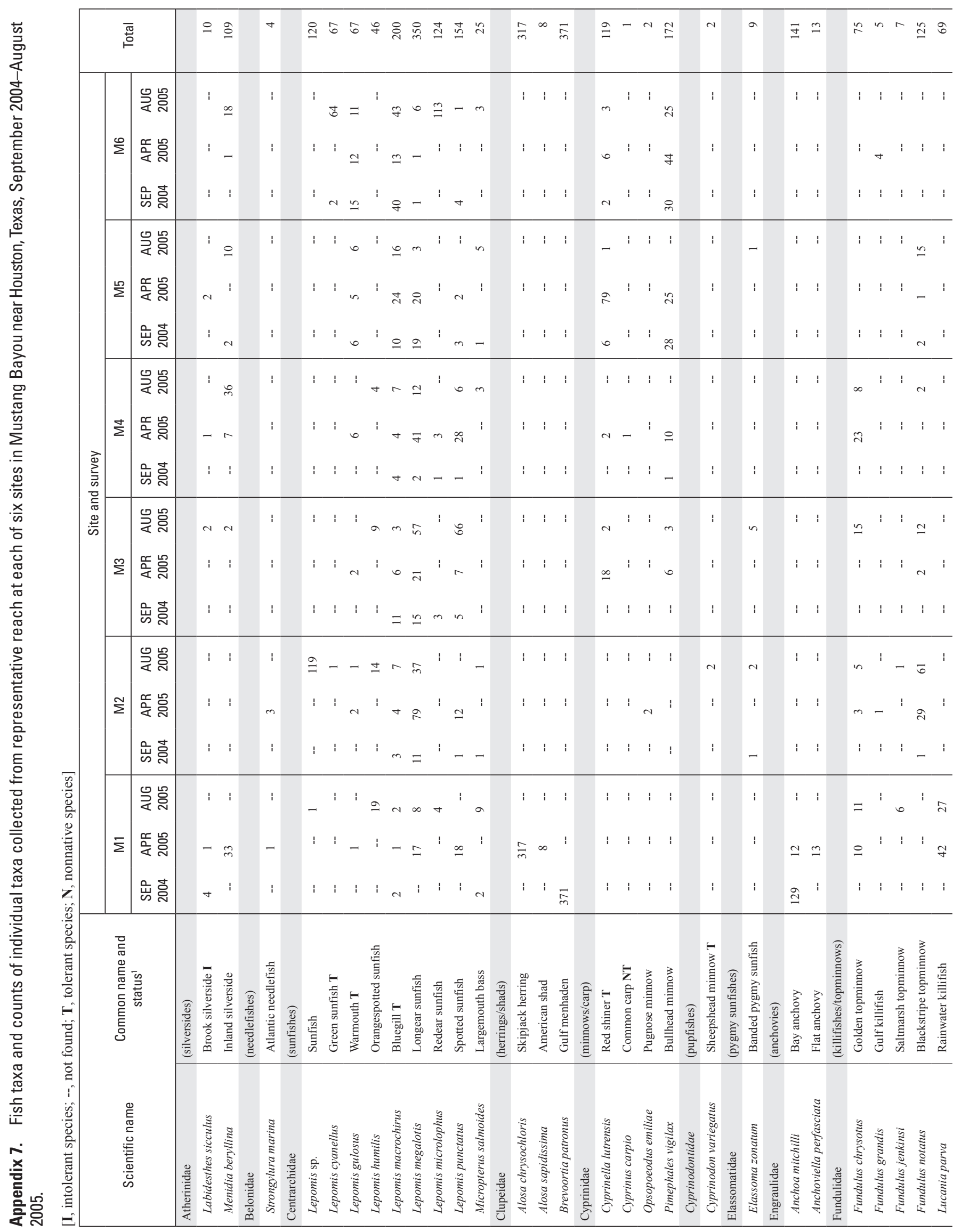




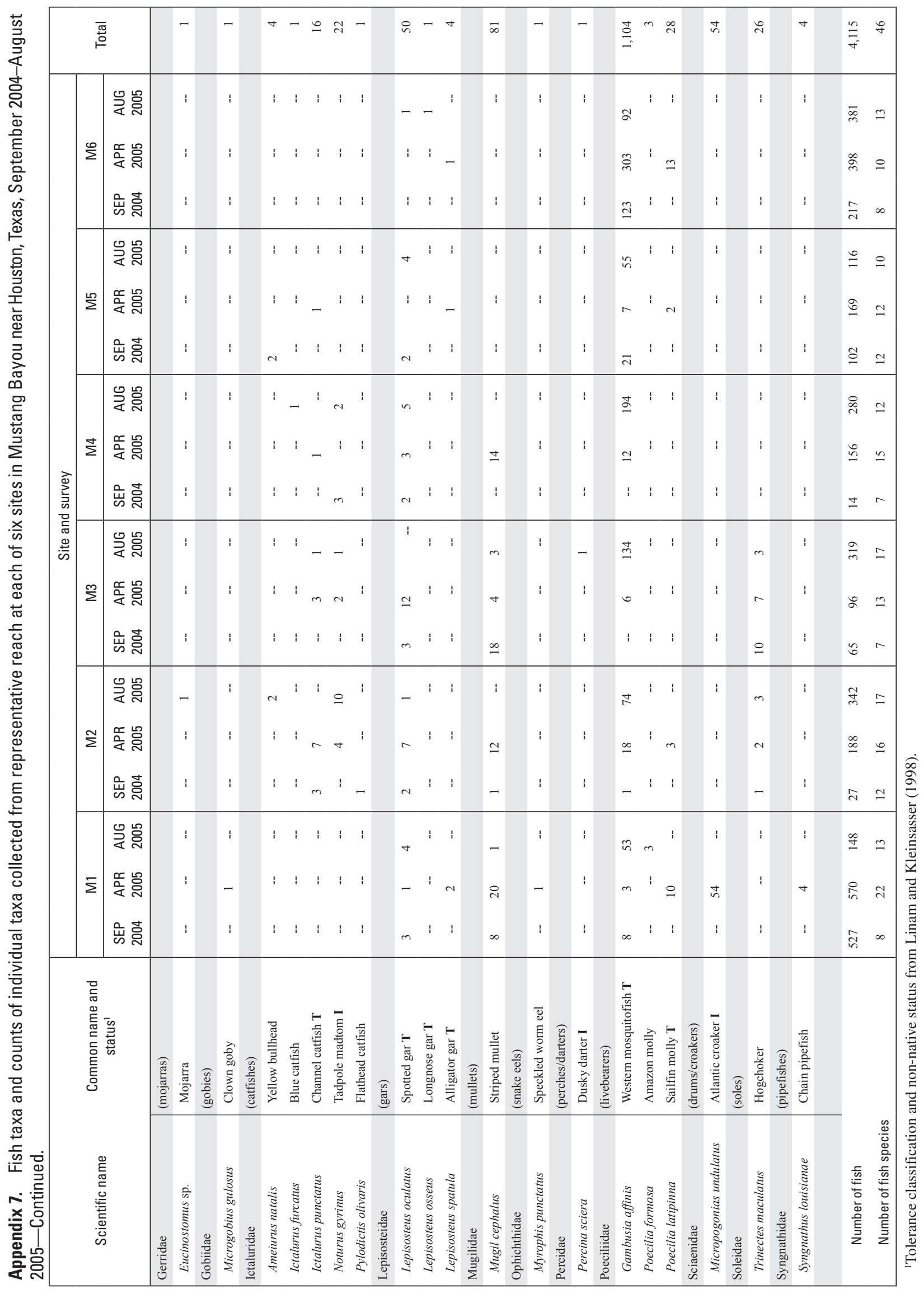


Appendix 8-Fish-Community Data and Computed Metrics 
Blank Page 


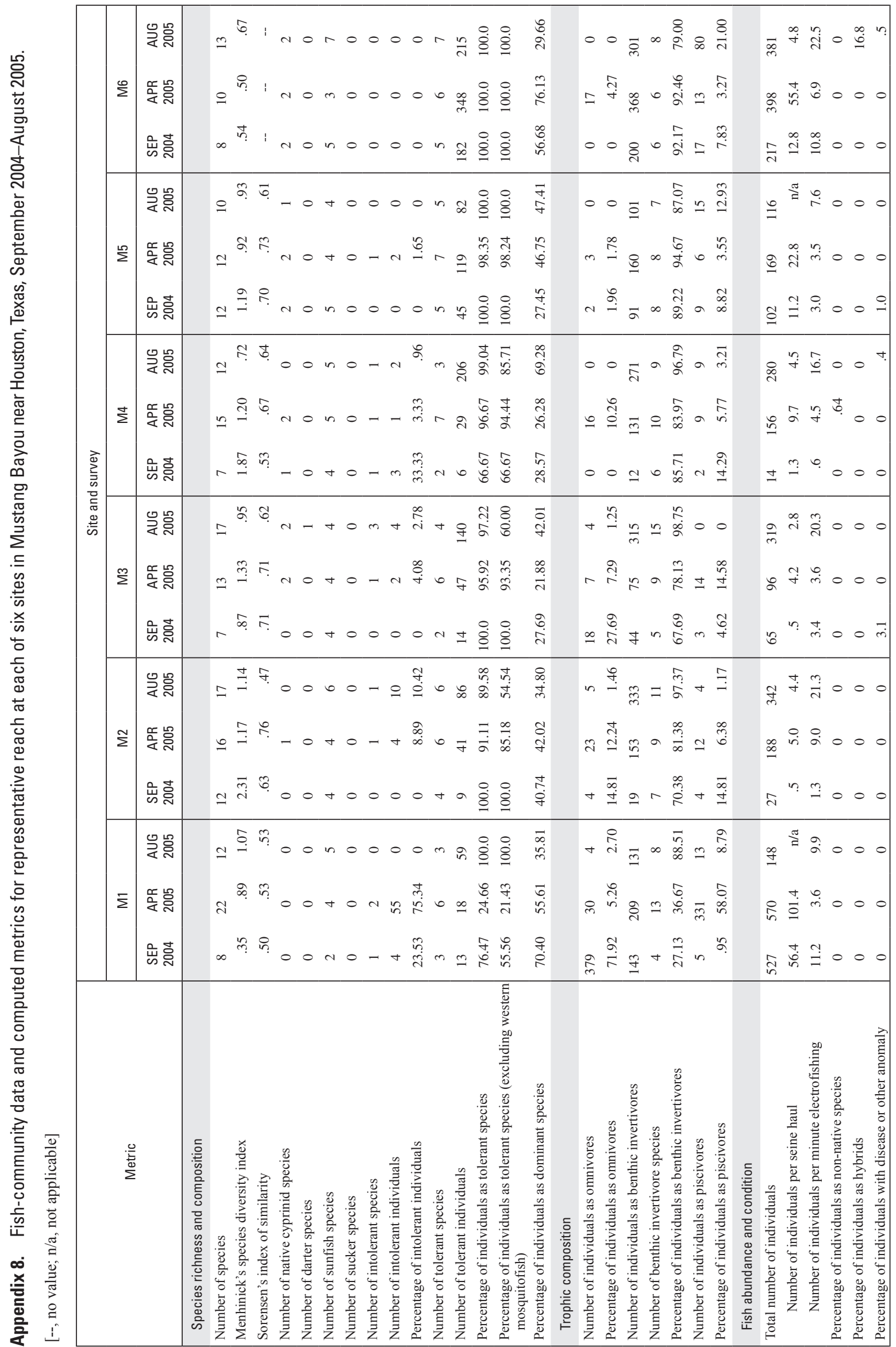


Prepared by the USGS Lafayette Publishing Service Center.

Information regarding water resources in Texas is available at http: //tx.usgs.gov/ 